Andrea Larissa Boesing

\title{
Landscape processes underpinning bird persistence and avian-mediated pest control in fragmented landscapes
}

São Paulo

2016 
Andrea Larissa Boesing

Landscape processes underpinning bird persistence and avian-mediated pest control in fragmented landscapes

\section{Persistência de aves e controle de pragas em paisagens fragmentadas - uma perspectiva da ecologia de paisagens}

Tese apresentada ao Instituto de Biociências da Universidade de São Paulo, para a obtenção de Título de Doutor em Ciências, na Área de Ecologia.

Orientador: Jean Paul Metzger Co-orientadora: Elizabeth Nichols 


\section{FichaCatalográfica}

Boesing, Andrea Larissa

Persistência de aves e controle de pragas

em paisagens fragmentadas - uma

perspectiva da ecologia de paisagens

181 páginas

Tese (Doutorado) - Instituto de

Biociências da Universidade de São Paulo.

Departamento de Ecologia.

1.Estrutura da paisagem

2.Cobertura florestal

3.Mata Atlântica

Universidade de São Paulo. Instituto de Biociências. Departamento de Ecologia.

Comissão Julgadora:

Prof(a). $\operatorname{Dr}(a)$

Prof(a). Dr(a).
Prof(a). Dr(a).

Prof(a). $\operatorname{Dr}(a)$.

Prof. Dr. Jean Paul Metzger

Orientador(a) 
Dedico...

"Àquela que sempre motivou a busca dos sonhos mais ousados,

Que me ensinou a soltar as amarras, Que me mostrou como ser forte e nunca desistir.

A você, meu exemplo de mulher e sabedoria, Que acompanhou o começo da jornada, mas infelizmente não o fim..."

Cila Friedrich Boesing (In memorian) 


\section{Epigraph}

Hold fast to dreams

For if dreams die

Life is a broken-winged bird

That cannot fly.

Hold fast to dreams

For when dreams go

Life is a barren field

Frozen with snow.

Langston Hughes 


\section{Acknowledgments}

Este trabalho é resultado de um esforço conjunto que envolveu muitas pessoas. Com toda certeza, agora que esta etapa esta próxima do fim, o sentimento é de gratidão para com cada pessoa que cruzou o meu caminho nesta empreitada. Sinto-me afortunada por todas as amizades e por todo o aprendizado durante esta caminhada e pelas experiências compartilhadas. Muito obrigada a todos que de uma maneira ou de outra, fizeram esta jornada tão especial, a qual foi uma etapa muito importante na minha vida. E sim, senta que lá vem história e cinco páginas de agradecimentos.

Agradeço primeiramente ao Jean por ter me acolhido no LEPaC há quatro anos atrás, por todo o apoio durante o desenvolvimento do projeto, pelas ideias compartilhadas, pelos puxões de orelha sempre em boa hora, e pela confiança em mim depositada. Aprendi muito neste período Jean, e lhe tenho como exemplo e fonte de inspiração para minha carreira. Sou muito grata pela oportunidade de ser parte do LEPaC.

Agradeço de coração à Liz, por todo auxilio e amizade durante o desenvolvimento deste trabalho, desde o inicio da fase de GIS e seleção das paisagens, de nossas primeiras aventuras à região da Cantareira, até os últimos instantes com correções, leitura, mais correções, puxões de orelha, motivação, mais puxões de orelha... Sou grata pelos tantos momentos compartilhados em campo ou fora dele. Obrigada pela motivação, por ter acentuado meu vício em café, pela troca de ideias, pelos 'insights de campo - 'IdC', e por tudo que me ensinou neste período.

Agradeço a todo o pessoal do LEPaC, pela parceria, convívio e experiência única de trabalhar com um grupo tão bacana. Este período não teria sido o mesmo sem o carisma e companheirismo de vocês. Sou grata por todo aprendizado e por tantos momentos que compartilhamos, em lab ou fora dele. Obrigada Isa, Ká, Chico, Feli, Juarez, Nati, Lê, Mel, Amanda, Paula, Camila, Caro, Vivi, por fazerem este período tão especial. 
Um agradecimento cheio de carinho vai aos mais de 260 proprietários e moradores das áreas de estudo que permitiram o acesso aos sítios amostrais. Em especial aos vizinhos de Joanópolis e Nazaré Paulista - onde a base de campo foi estabelecida no último ano - seu Persival e D. Maria (in memorian), Dona Esmeralda e Seu Brasilino. Obrigada pela amizade e disponibilidade em ajudar a resolver qualquer problema logístico durante a fase de campo. Pelas conversas jogadas fora, pela companhia e paciência, e por sempre nos receberem com um sorriso no rosto. Agradecimento especial ao Seu Carlos Abe no Bairro do Guirra, e também à Maria Lucia em Tapiratiba, que disponibilizaram suas casas para minha estadia enquanto em campo. Um agradecimento cheio de carinho a querida D. Maria em Tapiratiba, sempre atenciosa e preocupada com meu bem estar toda vez que eu "me enfiava no mato". Agradeço à toda família Leite por todo suporte logístico principalmente no início da campanha em Poços de Caldas, e à Dona Leny, pela presença amiga e cuidado para conosco enquanto ficávamos em sua casa.

Agradeço à todos os muitos companheiros de campo, desde os primeiros passos de reconhecimento das paisagens, conversas com proprietários, aberturas de trilhas, projeto piloto, e coleta de dados. 0 agradecimento vai em especial ao Bolinho (Fernando Ribeiro) com o qual dividimos muitos momentos bons e outros não tão bons em tempos de validação das paisagens, se aventurando pelos lugares que nunca havíamos pisado, procurando os melhores caminhos, encalhando rotineiramente, procurando pessoas nos lugares mais inóspitos, correndo de boi, de cachorro, de vespa, de gente... Obrigada Bolinho! Obrigada também pelo auxilio na hora da marcação e abertura das trilhas, o qual me ajudou quase que na totalidade das trilhas na região da Cantareira, e obrigada pela amizade incondicional durante todo este período. Agradeço também de maneira especial, ao Adrian, ao Juarez, e à Meme, que me auxiliaram em algumas campanhas de campo na região de Poços e Extrema, ajuda a qual foi imensurável.

Agradeço aos companheiros da fase de amostragem do capítulo que acabou nem sendo incluído na tese (mas que em breve será desenvolvido), que envolve os inenarráveis moradores da Casa das Vespas. Gurizada, obrigada por tornarem o campo tão mais leve e divertido. Em especial, agradeço ao Paulinho que morou em campo comigo por quatro meses na fase de captura com redes. Agradeço em 
especial também ao Beier, que veio do Rio Grande do Sul especialmente para auxiliar durante 3 semanas, e por me aturar já tem uns 7 anos!! Agradeço ao Gorfo's team (Paulim, Beier, André, Gabriel e Vivi), à Cachorrada (Lu, Elvira, Vini, Fer), e ao time rola-bosta (Vivi, Gabriel, Liz).. A companhia de vocês foi essencial para a manutenção da sanidade mental e pelo campo ter sido um período tão incrível. Sem vocês o campo não teria sido o mesmo.

Agradecimento especial também vai ao Welton em Poços de Caldas, que me ajudou com todas as trilhas na região cafeeira, sempre com um sorriso no rosto e que tanto me ensinou sobre a região Mogiana e sobre o cultivo do café.

Agradeço ao muitos motoristas do IB que me acompanharam (com diferentes níveis de entusiasmo...haha), mas que em meio ao meu stress diário em campo davam seu melhor pra evitar que eu subisse algumas pirambas a mais, ou demorasse demasiadamente, e que sempre entenderam o horário ingrato de atividade dos passarinhos. Muito obrigada Valdir, Valmir, Kleber, Marcelo e Amaral.

Agradeço à Prof. Renata Pardini, por sua insistência e olhar cuidadoso durante o delineamento experimental e seleção das paisagens, por toda sua acuidade e competência em fazer Bolinho e eu ter todo o cuidado na hora de sorteio e validação dos pontos de amostragem.

Agradeço ao Prof. Luis Fabio da Silveira, do Museu de Zoologia da USP, que me emprestou o material de coleta para captura das espécies tão logo que o trâmite de compra das redes estava demorando demasiadamente.

Agradeço aos Professores Ricardo Bovendorp e Marcus Cianciaruso, pelo auxílio no processo de aprendizagem, operacionalização, e interpretação das métricas de diversidade funcional e filogenética.

Agradeço à Meme (Melina Leite) e ao Sandev (Daniel Dantas), pelas inúmeras vezes que me socorreram em momentos de problemas com o R.

Agradeço ao Welington no LEPaC por fazer nossa vida um zilhão de vezes mais fácil, sempre prático e eficiente, tendo sempre uma solução para os problemas tecnológicos e computacionais. 
Um agradecimento especial também à "Veritchaa” (Vera Lucia), que faz nossa vida tão mais fácil no Departamento. Obrigada Vera pela força durante todo o processo, desde quando eu estava em campo, na gringolândia, ou em São Paulo, especialmente nas últimas semanas pelo apoio moral e psicológico.

I am thankful to Prof. Kathryn Sieving who hosted me during my Exchange at University of Florida, providing all logistical support. I really appreciate all Sieving's Lab members for the patience and discussions about my research.

I am thankful to Professor Scott Robinson, one of the most recognized tropical ornithologists in the world, for his kindly invitation to participate in his Lab meetings at University of Florida, and substantially contribute to bird's classification, and for sharing ideas on bird persistence in anthropogenic landscapes. I am thankful to Professor Bob Holt as well, who demonstrated so much interest for my work and also shared so many ideas and contribution to data discussion.

E agradeço àqueles que durante todo o período, não me deixaram surtar. Agradeço à minha família, em especial meu pai e meu irmão mais novo, sempre apoiadores das minhas decisões e sempre compreensíveis com meus campos e deadlines. Obrigada por apoiarem minha decisão de fazer o doutorado mesmo no momento mais difícil de nossas vidas. Meu agradecimento vai também em forma de pedido de desculpas, pela ausência neste período, pela ausência em muitos momentos que deveria estar presente, e pelos meses que fiquei sem dar as caras em casa.

Obrigada vai também à minha família buscapé (Tia Barbara, Tio Aroldo, Rodrigo(s) e Aline), por sempre me acolherem de braços abertos em cada fugida para casa, pelos assados de pinhão, cuca de banana, e o chimarrão sempre à espera. Agradeço especialmente a minha mãezinha "postiça" Tia Barbara, que tanto ajuda a preencher o vazio que minha mãe deixou e que olha meu little brô por mim enquanto estou nessa loucura.

Às moradoras do Refúgio, Meme e Pati, que me acolheram em São Paulo há 4 anos atrás e me aguentaram todo esse tempo mesmo ficando mais tempo em campo ou na USP do que em casa (talvez por isso me aguentam...). Obrigada também ao Jóqui, 
pela companhia, apoio e histórias nas madrugadas em fase de escrita. Obrigada por tudo e devo desculpas a vocês também, pela ausência constante.

I am thankful to Harry Jones, who became my best friend and a whole inspiration during my stay in US. In spite being my coffee buddy, I'm so thankful for making my stay in your country so much easier, and for being such a loyal and present friend even 4,000 miles away. I have no words to describe how blessed I'm to have gotten met you.

Agradeço ao meu Brazilian crew na gringa: Sandev, Rafa e Takao, por tantos bons momentos compartilhados! Sandev, obrigada por todos os cafés, todos os almoços no chrisna, por todas as conversas malucas sem pé nem cabeça, por todas as cervejas boas, por toda ajuda em R quando eu penava, e por ser este doce de pessoa que não vê maldade no mundo. Takao, que foi imprescindível especialmente nos primeiros meses morando fora. Obrigada pela paciência, pela amizade verdadeira, e pelos doughnuts sempre em boa hora. Rafa querida, sempre tão calma e tranquila que transbordava positividade todos os dias e me deixava tranquila só com a presença dela.

Agradeço à Melina Melito, por ter se tornado uma irmã em São Paulo, na alegria e na tristeza, no vinho ou na cerveja, no temaki do postinho ou no hambúrguer do tio radialista, e em todas as fases de alegria e desespero de desenvolvimento da tese.

Agradeço ao Leleco (Leandro Pereira), que mesmo de longe está sempre por perto. 0 agradecimento não vai não só por esta fase, mas pelos mais de 6 anos de amizade, e por estar do meu lado em todos os momentos - sejam eles bons ou os piores que já passei.

Este trabalho teve apoio financeiro da FAPESP, pelo financiamento do Projeto Temático Interface (2013/23457-6) e pelo financiamento da minha bolsa de pesquisa. Também recebi apoio financeiro da CAPES e do CNPQ (bolsas de estudo). Este trabalho também teve suporte financeiro da Rufford Small Grant Foundation concedido no inicio do projeto o qual garantiu os primeiros meses de campo antes do auxilio FAPESP ser obtido. 


\section{Index}

General Introduction

Chapter 1. Effects of landscape structure on avian-mediated insect pest control services

Abstract................................................................................. 23

Introduction.............................................................................. 24

Literature review ..................................................................... 25

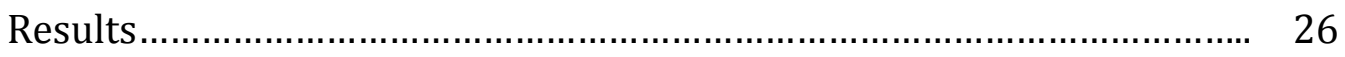

Discussion................................................................................ 31

Concluding remarks .................................................................... 39

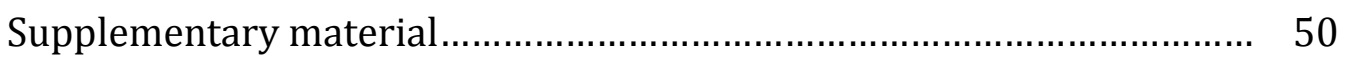

Chapter 2. Taxonomic, functional, and phylogenetic thresholds are modulated by matrix composition ................................................................ 81

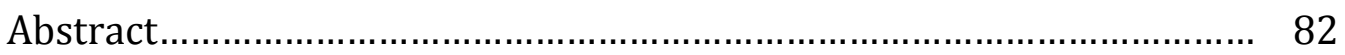

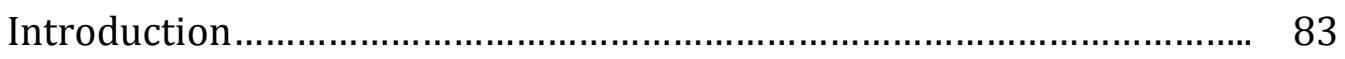

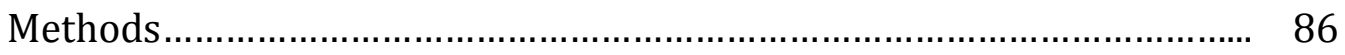

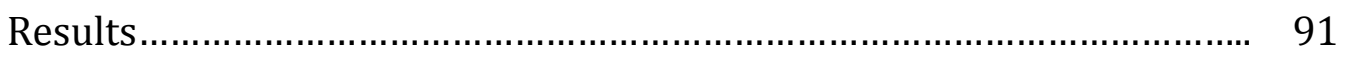

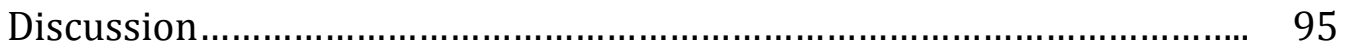

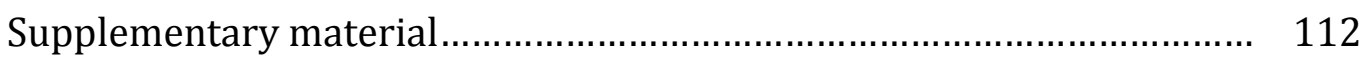

Chapter 3. How does landscape structure modulate avian cross-habitat

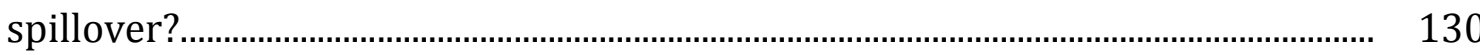

Abstract................................................................................ 131

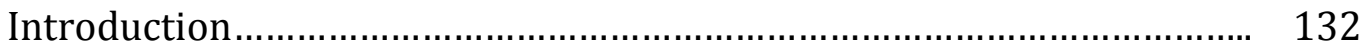

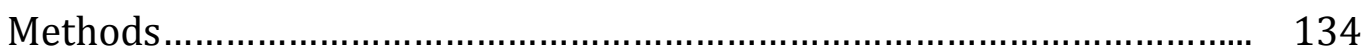

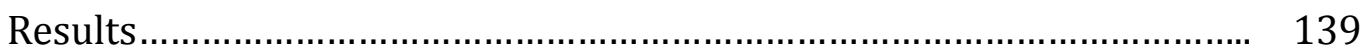

Discussion................................................................................... 141

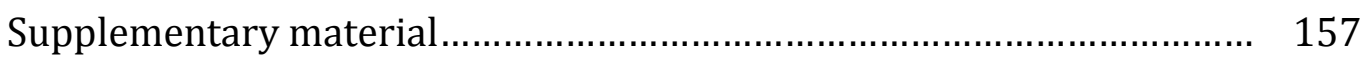

General Discussion ............................................................................ 173

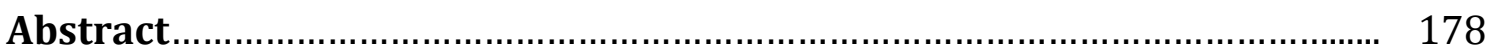

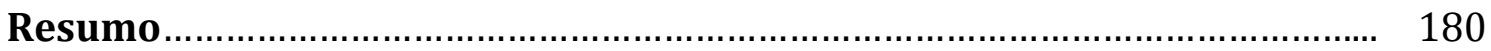




\section{General Introduction}

Globally, the current extent of conversion of native land cover to agricultural production is expanding faster than any time over the last 50 years (Grassini et al. 2013). Croplands and pastures have become the largest landscape components on the planet, occupying 40\% of its land surface (Ramankutty and Foley 1999, Asner et al. 2004). Meanwhile, habitat loss is one of the main drivers of species extinction worldwide (Fahrig 1997, Dirzo and Raven 2003), reducing population sizes and increasing extinction probability due to demographic or environmental stochasticity (Burkey 1995). Although species extinction has always been part of Earth's history (Pimm et al. 1995), the current extinction crisis is occurring more rapidly than throughout geological time, prompting talk of a sixth mass extinction (Barnosky et al. 2011, Steffen et al. 2015).

The influence of habitat loss on biodiversity is tied to a series of non-linear relationships between the amount of native habitat remaining and landscape configuration that strongly affect isolation and connectivity processes determining both extinction and colonization rates (Andren 1994, Fahrig 2003, 2013). Different spatial configurations of a given habitat amount might affect species persistence due to functional connectivity (i.e. the degree to which landscapes actually facilitate or impede the movement of organisms; Fahrig 1998) - at least between certain thresholds of remaining habitat (Andren 1994, Villard and Metzger 2014). Extinction threshold theory predicts that there is a minimum suitable amount of habitat required by a given species or assemblage to persist in an environment (Andren 1994, Fahrig 1997). This theory predicts that as the proportion of habitat amount in a landscape decreases, species persistence is affected not only by habitat loss per se, but also by effects at the patch scale such as edge and area effects (Andren 1994, Villard and Metzger 2014).

Although habitat fragmentation theory is based on island biogeography and metapopulation theory (i.e. assuming matrix as inhospitable and homogeneous; (Haila 2002, Jules and Shahani 2003, Kupfer et al. 2006), the matrix surrounding habitat patches is often composed of a complex mosaic of land cover types (Ricketts 2001). Because of this heterogeneity, the matrix type where habitat 
patches are embedded must play a key role affecting dispersal ability of species, influencing (re)colonization and extinction rates, and possibly changing extinction thresholds. Matrix composition can range from structurally simple matrices dominated by homogeneous arable lands to structurally complex ones, with high amounts of non-crop areas or components such as mixed plantations or agroforestry systems (Tscharntke et al. 2007), with different degrees of resistance to organisms' movement (Ricketts 2001). In addition to influencing species abundance and composition through movement and dispersal, the matrix surrounding habitat patches might also provide additional resources and affect the abiotic environment of patches (Driscoll et al. 2013, Prevedello et al. In press). While corridors and stepping stones have received much recent empirical attention (Levey et al. 2005, Haddad et al. 2014, Haddad 2015), the role of matrix composition in influencing biological processes such as dispersal and resources provisioning is still a challenging issue (Ricketts 2001, Prevedello and Vieira 2010, Driscoll et al. 2013).

Ultimately, landscape changes due anthropogenic disturbances are driving not only species loss per se, but also loss of functions performed by those species and their interactions (Mokross et al. 2014, Jordano 2016), and a whole evolutionary history is threatened as well (Hooper et al. 2005). As a consequence, losses in taxonomic diversity are accompanied by important changes in functional diversity (i.e. the diversity of functional traits across a community; Jarzyna and Jetz 2016), which may significantly impact ecosystem function (Bregman et al. 2014, Oliver et al. 2015), and by losses of phylogenetic diversity (i.e. the evolutionary history of a species assemblage; Webb 2000) that potentially curtail future resilience in both biodiversity and function (Frishkoff et al. 2014). A meta-analysis of biodiversity-ecosystem functions studies suggests that the impact of biodiversity losses on ecosystem functions is comparable (or even worse) in scale with that of other global changes such as climate change (Hooper et al. 2005). Moreover, declines in the number of individuals in local populations and changes in species composition in a community will strongly affect ecosystem functioning as well (Sekercioglu 2006).

Ultimately, biodiversity losses have been documented to undermine the provisioning of ecosystem services - defined as the benefits that humans derive 
from nature (MEA 2005, TEEB 2010). Recent calls to create agricultural landscapes that simultaneously provide ecosystem services and support high biodiversity (Mooney et al. 2010, DeClerck et al. 2015) have highlighted the importance of understanding how landscape structure and composition influence the provisioning of ecosystem services (Turner et al. 2013, Wu 2013, Mitchell et al. 2015). Particularly, we need to estimate how much native habitat is required to maintain certain biodiversity standards and ecosystem functionality (Fahrig 2002, Ficetola and Denoel 2009), including providing some ecosystem services. As native land-cover provides critical habitat for many mobile organisms that offer ecosystem services in agricultural systems (Bianchi et al. 2006, Tscharntke et al. 2012, Karp et al. 2013), retaining native habitats nearby crop fields might result in considerable economic gain for landholders (Ostman et al. 2001, Karp et al. 2013) and might be a clear justification for habitat conservation in working agricultural landscapes.

Birds are an extremely useful taxon for investigating questions integrating effects of landscape structure and provisioning of ecosystem services. First, birds have an extremely diverse range of functional traits, allowing them to use a huge variety of resources (Sekercioglu et al. 2016), which makes them special from the perspective of ecosystem services provisioning (Whelan et al. 2008). Second, birds are especially mobile organisms, which allows them actively search and respond to pulses of resources in ways not generally possible for other vertebrates, allowing them to leave areas in which resources are no longer sufficient and relocate to more productive locations (Whelan et al. 2008). Finally, they have high massspecific metabolic rates, which translates to a constant need for resources especially during the breeding season, when nestlings require a protein-rich diet. In this context, insectivorous birds might play a significant role in controlling insect populations, making them special in terms of pest control services in agricultural landscapes (Van Bael et al. 2008). Moreover, insectivorous birds are ubiquitous, abundant, and essential components of most terrestrial ecosystems (Sekercioglu 2006), and by far the most diverse avian functional group with more than 7,400 species worldwide.

Herbivorous insects are responsible destroying one fifth of the world's total crop production, with an estimated economic impact of billion dollars annually 
(Bonning and Chougule 2014). Pest proliferation leads, especially in monocultures, not only to problems related to crop losses (Matson et al. 1997, Laxminarayan and Simpson 2000), but also to serious concerns related to the long-term environmental sustainability of agricultural systems. Natural pest control can be considered as an alternative method to minimize these problems (Bianchi et al. 2006, Losey and Vaughan 2006, Oerke 2006). Taking advantage of natural enemies for pest suppression can enhance and stabilize yield resilience in crop production systems, avoiding complex collapses due to eroded natural regulation (Bommarco et al. 2011, Bommarco et al. 2013). For example, pest control services provided by biodiversity prevent approximately $\$ 13.6$ billion in agricultural losses in the Unites States annually (Losey and Vaughan 2006). However, the effect of landscape components on the rate and magnitude of pest-control services has rarely been quantified (Tscharntke et al. 2007, Schellhorn et al. 2008), preventing a general understanding of how landscape structure regulates pest-control services.

The main objective of this thesis is to move beyond our current understanding about landscape processes underpinning bird persistence in fragmented landscapes and avian-mediated pest control. We start this work by systematically reviewing the literature for empirical evidence of landscape structure effects on avian-mediated pest control in agricultural systems worldwide. Then, using bird data collected in fragmented landscapes in the Brazilian Atlantic forest, we test for community-level extinction thresholds across a range of biodiversity facets (taxonomic, functional, and phylogenetic diversity) in order to evaluate how much habitat is need to maintain sustainable ecosystem functioning and ecosystem resilience, and how matrix composition might affect these thresholds. Finally, we investigate one of the main processes regulating avian-mediated pest control in tropical regions as determined in our literature review: cross-habitat spillover. The main justification and objectives of each chapter are detailed below.

The chapter one is based on a systematic literature review investigating current empirical evidence of the influence of landscape structure on avianmediated pest control. Despite increasing evidence that landscape composition and configuration strongly influence patch-level diversity, abundance, and composition (Pardini et al. 2010, Banks-Leite et al. 2014), landscape structure has 
seldom been explicitly linked with rate and magnitude of pest-control services (Tscharntke et al. 2012). We identify the main landscape features affecting avianmediated pest control worldwide, in both tropical and temperate biomes and across a range of avian predator types varying in habitat association and diet specialization. We present a conceptual model of the landscape processes and biodiversity mechanisms underlining these relationships, and use this model to identify key research gaps and opportunities for future studies. This chapter is under review in the journal Landscape Ecology.

In order to evaluate how much habitat is need to maintain sustainable biodiversity patterns aiming to sustain ecosystem functioning and ecosystem resilience, chapter two investigates how matrix composition might modulate extinction thresholds of taxonomic, functional and phylogenetic diversity of Brazilian Atlantic forest avifauna. Biodiversity is one of multiple factors that govern ecosystem properties, and changes to both number and identity of species, and functional diversity imposed by human actions can yield ecosystem effects that vary from small to far-reaching and cascading (Naeem et al. 2012, Jordano 2016). Using approaches incorporating both functional attributes and life history patterns might increase our predictive power about the impacts of land use conversion and fragmentation. Even though it is suggested that extinction thresholds for avian taxonomic diversity occur at around 18-33\% of habitat remaining (Betts et al. 2007, Banks-Leite et al. 2014, Richmond et al. 2015), the influence of matrix composition on these thresholds and the thresholds for other measures of biodiversity are unknown.

Cross-habitat spillover is often defined as the movement (e.g. encompassing dispersal and foraging) of organisms from one habitat type to another (Tscharntke et al. 2012). Among the knowledge gaps identified in chapter one, cross-habitat spillover of forest-dependent species into agricultural matrices is a process that deserves particular attention and is thus the subject of chapter three. Natural habitats adjacent to crop fields are often seen as source habitat for species providing beneficial regulating ecosystem services such as pest control and pollination in agricultural areas (Bianchi et al. 2006, Kremen et al. 2007). Understanding how habitat configuration and matrix permeability affect the movement of service-providing biodiversity is a key applied management concern 
(Blitzer et al. 2012), especially in light of the current agricultural expansion. This chapter investigates these related ideas, testing how landscape structure and matrix composition affect avian cross-habitat spillover of forest-dependent species into the agricultural matrices using field data collected in fragmented landscapes in the Brazilian Atlantic forest, an imperiled ecosystem.

Finally, we conclude this dissertation with a general discussion of our results and their implications for landscape-level management. We discuss how to improve agricultural areas via the maintenance of biodiversity-friendly crop fields, the persistence of forest specialized species in these highly fragmented landscapes, and the enhancement of the provisioning of ecosystem services.

\section{Literature cited}

Andren H. (1994). Effects of habitat fragmentation in birds and mammals in landscapes with different proportions of suitable habitat - a review. Oikos, 71, 355-366.

Asner G.P., Elmore A.J., Olander L.P., Martin R.E. \& Harris A.T. (2004). Grazing systems, ecosystem responses, and global change. Annu Rev Env Resour, 29, 261-299.

Banks-Leite C., Pardini R., Tambosi L.R., Pearse W.D., Bueno A.A., Bruscagin R.T., Condez T.H., Dixo M., Igari A.T., Martensen A.C. \& Metzger J.P. (2014). Using ecological thresholds to evaluate the costs and benefits of set-asides in a biodiversity hotspot. Science, 345, 1041-1045.

Barnosky A.D., Matzke N., Tomiya S., Wogan G.O.U., Swartz B., Quental T.B., Marshall C., McGuire J.L., Lindsey E.L., Maguire K.C., Mersey B. \& Ferrer E.A. (2011). Has the Earth's sixth mass extinction already arrived? Nature, 471, 51-57.

Betts M.G., Forbes G.J. \& Diamond A.W. (2007). Thresholds in songbird occurrence in relation to landscape structure. Conserv Biol, 21, 1046-1058.

Bianchi F.J.J.A., Booij C.J.H. \& Tscharntke T. (2006). Sustainable pest regulation in agricultural landscapes: a review on landscape composition, biodiversity and natural pest control. P Roy Soc B-Biol Sci, 273, 1715-1727.

Blitzer E.J., Dormann C.F., Holzschuh A., Klein A.-M., Rand T.A. \& Tscharntke T. (2012). Spillover of functionally important organisms between managed and natural habitats. Agr Ecosyst Environ, 146, 34-43.

Bommarco R., Kleijn D. \& Potts S.G. (2013). Ecological intensification: harnessing ecosystem services for food security. Trends Ecol Evol, 28, 230-238.

Bommarco R., Miranda F., Bylund H. \& Bjorkman C. (2011). Insecticides Suppress Natural Enemies and Increase Pest Damage in Cabbage. J Econ Entomol, 104, 782-791. 
Bonning B.C. \& Chougule N.P. (2014). Delivery of intrahemocoelic peptides for insect pest management. Trends Biotechnol, 32, 91-98.

Bregman T.P., Sekercioglu C.H. \& Tobias J.A. (2014). Global patterns and predictors of bird species responses to forest fragmentation: Implications for ecosystem function and conservation. Biol Conserv, 169, 372-383.

Burkey T.V. (1995). Extinction rates in archipelagoes - implications for populations in fragmented habitats. Conserv Biol, 9, 527-541.

DeClerck F., Estrada-Carmona N., Garbach K. \& Martinez-Salinas A. (2015). Biodiversity and Ecosystem Services of Agricultural Landscapes: reversing agriculture's externalities. In: Agroecology for Food Security and Nutrition Proceedings of the FAO International Symposium. FAO Rome, Italy, pp. 140-157.

Dirzo R. \& Raven P.H. (2003). Global state of biodiversity and loss. Annu Rev Env Resour, 28, 137-167.

Driscoll D.A., Banks S.C., Barton P.S., Lindenmayer D.B. \& Smith A.L. (2013). Conceptual domain of the matrix in fragmented landscapes. Trends Ecol Evol, 28, 605-613.

Fahrig L. (1997). Relative effects of habitat loss and fragmentation on population extinction. J Wildlife Manage, 61, 603-610.

Fahrig L. (1998). When does fragmentation of breeding habitat affect population survival? Ecol Model, 105, 273-292.

Fahrig L. (2002). Effect of habitat fragmentation on the extinction threshold: A synthesis. Ecol Appl, 12, 346-353.

Fahrig L. (2003). Effects of habitat fragmentation on biodiversity. Annu Rev Ecol Evol S, 34, 487-515.

Fahrig L. (2013). Rethinking patch size and isolation effects: the habitat amount hypothesis. J Biogeogr, 40, 1649-1663.

Ficetola G.F. \& Denoel M. (2009). Ecological thresholds: an assessment of methods to identify abrupt changes in species-habitat relationships. Ecography, 32, 10751084.

Frishkoff L.O., Karp D.S., M'Gonigle L.K., Mendenhall C.D., Zook J., Kremen C., Hadly E.A. \& Daily G.C. (2014). Loss of avian phylogenetic diversity in neotropical agricultural systems. Science, 345, 1343-1346.

Grassini P., Eskridge K.M. \& Cassman K.G. (2013). Distinguishing between yield advances and yield plateaus in historical crop production trends. Nat Commun, 4.

Haddad N.M. (2015). Corridors for people, corridors for nature. Science, 350, 1166-1167. 
Haddad N.M., Brudvig L.A., Damschen E.I., Evans D.M., Johnson B.L., Levey D.J., Orrock J.L., Resasco J., Sullivan L.L., Tewksbury J.J., Wagner S.A. \& Weldon A.J. (2014). Potential Negative Ecological Effects of Corridors. Conserv Biol, 28, 1178-1187.

Haila Y. (2002). A conceptual genealogy of fragmentation research: From island biogeography to landscape ecology. Ecol Appl, 12, 321-334.

Hooper D.U., Chapin F.S., Ewel J.J., Hector A., Inchausti P., Lavorel S., Lawton J.H., Lodge D.M., Loreau M., Naeem S., Schmid B., Setala H., Symstad A.J., Vandermeer J. \& Wardle D.A. (2005). Effects of biodiversity on ecosystem functioning: A consensus of current knowledge. Ecol Monogr, 75, 3-35.

Jarzyna M.A. \& Jetz W. (2016). Detecting the multiple facets if biodiversity. Trends Ecol Evol, In press.

Jordano P. (2016). Chasing ecological interactions. Plos Biol, 14, 1-4.

Jules E.S. \& Shahani P. (2003). A broader ecological context to habitat fragmentation: Why matrix habitat is more important than we thought. J Veg Sci, 14, 459-464.

Karp D.S., Mendenhall C.D., Sandi R.F., Chaumont N., Ehrlich P.R., Hadly E.A. \& Daily G.C. (2013). Forest bolsters bird abundance, pest control and coffee yield. Ecol Lett, 16, $1339-1347$.

Kremen C., Williams N.M., Aizen M.A., Gemmill-Herren B., LeBuhn G., Minckley R., Packer L., Potts S.G., Roulston T.a., Steffan-Dewenter I., Vazquez D.P., Winfree R., Adams L., Crone E.E., Greenleaf S.S., Keitt T.H., Klein A.-M., Regetz J. \& Ricketts T.H. (2007). Pollination and other ecosystem services produced by mobile organisms: a conceptual framework for the effects of land-use change. Ecol Lett, 10, 299-314.

Kupfer J.A., Malanson G.P. \& Franklin S.B. (2006). Not seeing the ocean for the islands: the mediating influence of matrix-based processes on forest fragmentation effects. Global Ecol Biogeogr, 15, 8-20.

Laxminarayan R. \& Simpson R.D. (2000). Biological limits on agricultural intensification: an example from resistance management. Resources for the Nature, Washington, DC.

Levey D.J., Bolker B.M., Tewksbury J.J., Sargent S. \& Haddad N.M. (2005). Effects of landscape corridors on seed dispersal by birds. Science, 309, 146-148.

Losey J.E. \& Vaughan M. (2006). The economic value of ecological services provided by insects. Bioscience, 56, 311-323.

Matson P.A., Parton W.J., Power A.G. \& Swift M.J. (1997). Agricultural intensification and ecosystem properties. Science, 277, 504-509.

MEA (2005). Millennium Ecosystem Assessment Synthesis, United Nations. 
Mitchell M.G.E., Suarez-Castro A.F., Martinez-Harms M., Maron M., McAlpine C., Gaston K.J., Johansen K. \& Rhodes J.R. (2015). Reframing landscape fragmentation's effects on ecosystem services. Trends Ecol Evol, 30, 190-198.

Mokross K., Ryder T.B., Cortes M.C., Wolfe J.D. \& Stouffer P.C. (2014). Decay of interspecific avian flock networks along a disturbance gradient in Amazonia. P Roy Soc B-Biol Sci, 281.

Mooney K.A., Gruner D.S., Barber N.A., Van Bael S.A., Philpott S.M. \& Greenberg R. (2010). Interactions among predators and the cascading effects of vertebrate insectivores on arthropod communities and plants. P Natl Acad Sci USA, 107, 7335-7340.

Naeem S., Duffy J.E. \& Zavaleta E. (2012). The Functions of Biological Diversity in an Age of Extinction. Science, 336, 1401-1406.

Oerke E.C. (2006). Crop losses to pests. J Agr Sci, 144, 31-43.

Oliver T.H., Isaac N.J.B., August T.A., Woodcock B.A., Roy D.B. \& Bullock J.M. (2015). Declining resilience of ecosystem functions under biodiversity loss. Nat Commun, 6.

Ostman O., Ekbom B. \& Bengtsson J. (2001). Landscape heterogeneity and farming practice influence biological control. Basic Appl Ecol, 2, 365-371.

Pardini R., Bueno A.D., Gardner T.A., Prado P.I. \& Metzger J.P. (2010). Beyond the Fragmentation Threshold Hypothesis: Regime Shifts in Biodiversity Across Fragmented Landscapes. Plos One, 5.

Pimm S.L., Russell G.J., Gittleman J.L. \& Brooks T.M. (1995). The future of biodiversity. Science, 269, 347-350.

Prevedello J.A., Gotelli N. \& Metzger J.P. (In press). A stochastic model for landscape patterns of biodiversity. Ecol Monogr.

Prevedello J.A. \& Vieira M.V. (2010). Does the type of matrix matter? A quantitative review of the evidence. Biodivers Conserv, 19, 1205-1223.

Ramankutty N. \& Foley J.A. (1999). Estimating historical changes in global land cover: Croplands from 1700 to 1992. Global Biogeochem Cy, 13, 997-1027.

Richmond S., Jenkins E., Couturier A. \& Cadman M. (2015). Thresholds in forest bird richness in response to three types of forest cover in Ontario, Canada. Landscape Ecol, 30, 1273-1290.

Ricketts T.H. (2001). The matrix matters: Effective isolation in fragmented landscapes. Am Nat, 158, 87-99.

Schellhorn N.A., Macfadyen S., Bianchi F.J.J.A., Williams D.G. \& Zalucki M.P. (2008). Managing ecosystem services in broadacre landscapes: what are the appropriate spatial scales? Aust J Exp Agr, 48, 1549-1559. 
Sekercioglu C.H. (2006). Foreword on the ecological significance of bird populations In: Handbook of birds of the world (eds. Del Hoyo J, Elliott A \& Christie DA). Lynx Edicions Barcelona, pp. 15-51.

Sekercioglu C.H., Wenny D.G. \& Whelan C.J. (2016). Why birds matter: avian ecological function and ecosystem services. The University of Chicago Press, Chicago, London.

Steffen W., Richardson K., Rockstrom J., Cornell S.E., Fetzer I., Bennett E.M., Biggs R., Carpenter S.R., de Vries W., de Wit C.A., Folke C., Gerten D., Heinke J., Mace G.M., Persson L.M., Ramanathan V., Reyers B. \& Sorlin S. (2015). Planetary boundaries: Guiding human development on a changing planet. Science, 347.

TEEB (2010). Mainstreaming the Economics of Nature: A Synthesis of the Approach, Conclusions and Recommendations of TEEB. In: Conference of Parties to the CBD (eds. P. S, H. W, C. S-S, C. N, J. B, Pt. B, H. G, P. K \& B. S) Nagoya, Japan.

Tscharntke T., Bommarco R., Clough Y., Crist T.O., Kleijn D., Rand T.A., Tylianakis J.M., van Nouhuys S. \& Vidal S. (2007). Conservation biological control and enemy diversity on a landscape scale. Biol Control, 43, 294-309.

Tscharntke T., Tylianakis J.M., Rand T.A., Didham R.K., Fahrig L., Batary P., Bengtsson J., Clough Y., Crist T.O., Dormann C.F., Ewers R.M., Frund J., Holt R.D., Holzschuh A., Klein A.M., Kleijn D., Kremen C., Landis D.A., Laurance W., Lindenmayer D., Scherber C., Sodhi N., Steffan-Dewenter I., Thies C., van der Putten W.H. \& Westphal C. (2012). Landscape moderation of biodiversity patterns and processes - eight hypotheses. Biol Rev, 87, 661-685.

Turner M.G., Donato D.C. \& Romme W.H. (2013). Consequences of spatial heterogeneity for ecosystem services in changing forest landscapes: priorities for future research. Landscape Ecol, 28, 1081-1097.

Van Bael S.A., Philpott S.M., Greenberg R., Bichier P., Barber N.A., Mooney K.A. \& Gruner D.S. (2008). Birds as predators in tropical agroforestry systems. Ecology, 89, 928934.

Villard M.-A. \& Metzger J.P. (2014). Beyond the fragmentation debate: a conceptual model to predict when habitat configuration really matters. J Appl Ecol, 51, 309-318.

Webb C.O. (2000). Exploring the phylogenetic structure of ecological communities: An example for rain forest trees. Am Nat, 156, 145-155.

Whelan C.J., Wenny D.G. \& Marquis R.J. (2008). Ecosystem services provided by birds. Year in Ecology and Conservation Biology 2008, 1134, 25-60.

Wu J. (2013). Landscape sustainability science: ecosystem services and human well-being in changing landscapes. . Landscape Ecol, 28, 999-1023. 


\title{
Chapter 1
}

\section{Effects of landscape structure on avian- mediated insect pest control services}

\author{
Andrea L. Boesing, Elizabeth Nichols, Jean P. Metzger
}

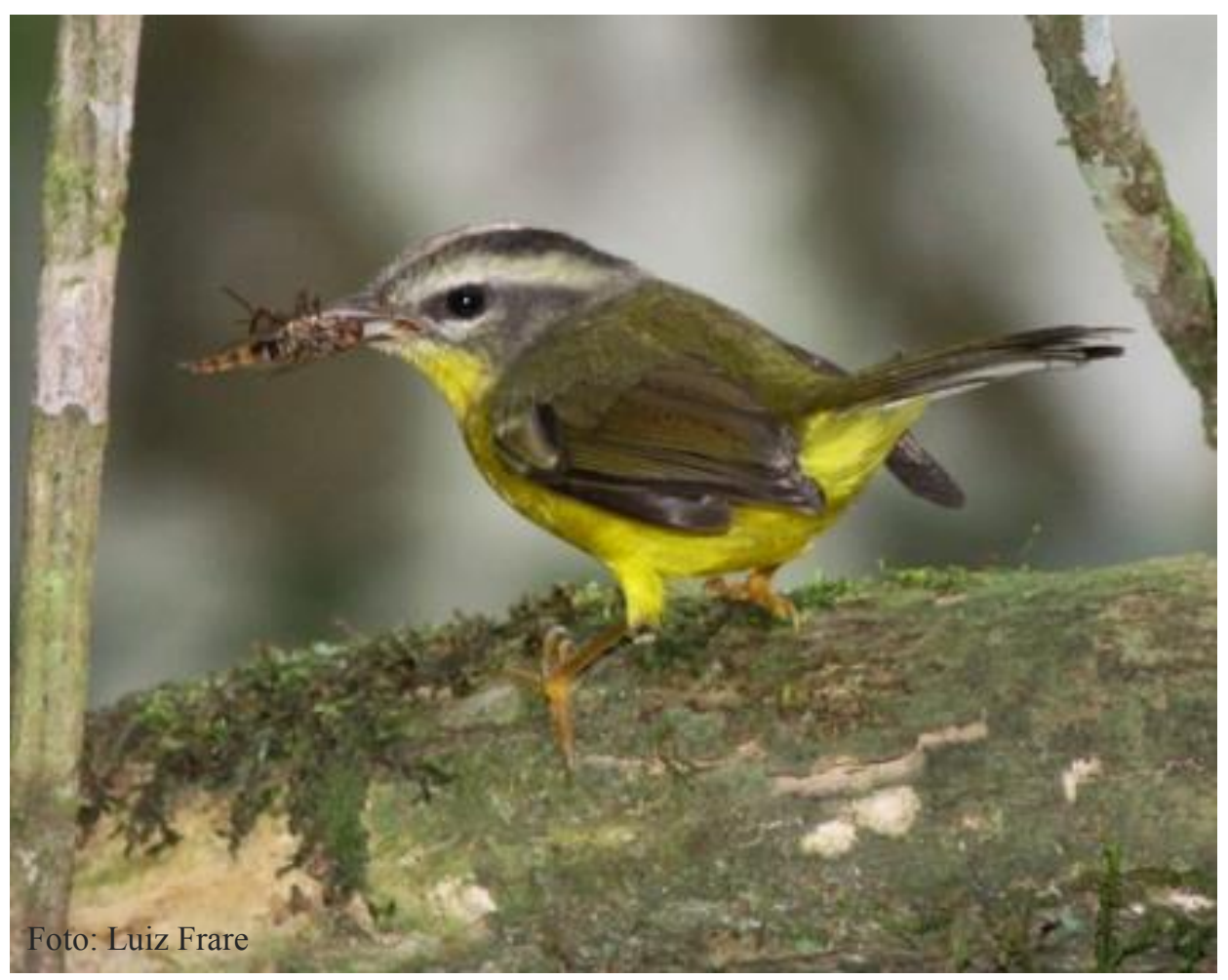

(Submitted to Landscape Ecology) 


\section{Abstract}

Insect crop pests cause massive annual economic loss through the destruction of crop yields. Despite increasing evidence that landscape composition and configuration strongly influence the community structure of potential pestregulators, landscape structure has seldom been explicitly linked with rate and magnitude of pest-control services. We conducted a systematic literature review to (1) characterize our existing understanding of the empirical relationships between landscape structure and avian-mediated insect pest control services in agricultural systems, (2) identify gaps in our current understanding, and (3) develop a new conceptual model of landscape structural influences avian-mediated pest control. We found that on-farm pest suppression by birds was often higher in landscapes with higher native habitat cover, higher compositional heterogeneity, and in agricultural patches in closer proximity to native habitat. We identified more than 200 bird species that provide pest control services across both temperate and tropical regions. While most avian predators are insectivorous and habitatgeneralist species, we found that a substantial fraction of pest control services in tropical regions was mediated by native habitat-dependent species, suggesting a link between conservation management and the maintenance of these pest control services. We identified a three-part research agenda for future investigations of the relationships between landscape structure and avian-mediated pest control services. This framework focuses on an improved understanding of the mechanisms related to: (1) predator-prey interactions and landscape modulation of trophic relationships, (2) bird dispersal ability and landscape connectivity, and (3) cross-habitat spillover of habitat-dependent avian predators. These findings can be applied to efforts to manage and design landscapes capable of supporting both biodiversity and ecosystem services.

Keywords: Avian predators. Birds. Conservation. Crop fields. Ecosystem services. Insect pests. Landscape ecology. Pest suppression. Sustainability. Tropical Forest. 


\section{Introduction}

As humans continue to modify natural ecosystems around the world, land conversion and intensification for agricultural production continues to drive a significant reduction in biodiversity and associated ecosystem services (Foley et al. 2005, MEA 2005, Cardinale et al. 2012). Simultaneously, efforts to create sustainable agricultural landscapes that support ecosystem services and biodiversity have highlighted several key knowledge gaps, including how landscape structure influences service provision (Turner et al. 2013, Wu 2013, Mitchell et al. 2015).

Pest regulation ecosystem services are particularly critical in agricultural landscapes. Herbivorous insects destroy approximately one fifth of the world's total crop production annually, with an estimated annual economic impact of billions of dollars (Bonning and Chougule 2014). The use of natural enemies for pest suppression can enhance and stabilize yields in crop production systems, as well as increase overall crop resilience by aiding in the avoidance of crop failure when chemical-based regulation fails (Bommarco et al. 2011, Bommarco et al. 2013).

Pest control services depend fundamentally on the spatial and temporal distribution of natural enemies at the patch-level, within and around crop fields (Hooper et al. 2005, Gagic et al. 2015). As most natural enemies are mobile organisms that move within and across habitats to access different resources (Jirinec et al. 2011, Karp et al. 2013), their local diversity and abundance is also strongly influenced by landscape-level structure and processes. For example, the amount and configuration (i.e. spatial arrangement) of both native and anthropogenic habitats within a landscape strongly influence natural enemy community structure within patches (Bianchi et al. 2006, Tscharntke et al. 2012, Karp et al. 2013, Martin et al. 2013), and movement between patches (Tscharntke et al. 2005), with subsequent impacts on rates of crop pest suppression (Ostman et al. 2001, Karp et al. 2013). While we increasingly understand how local biodiversity patterns are influenced by components of landscape structure, including composition, configuration, heterogeneity, and connectivity (Estavillo et al. 2013, Fahrig 2013, Banks-Leite et al. 2014), similar links between landscape structure and biodiversity-mediated pest-control services are scarce (Schellhorn et 
al. 2008, Tscharntke et al. 2008b). This precludes a more general understanding of how landscape structure may influence this key suite of ecosystem services.

Insectivorous birds provide significant pest control services (Karp et al. 2013, Maas et al. 2013, Maas et al. 2015), and may complement or replace chemical-based pest control strategies agricultural systems (Bianchi et al. 2006, Maas et al. 2015). However, the links between landscape structure and avianmediated insect pest control services are poorly known. We review the existing empirical evidence that links landscape structure and avian-mediated pest control services in agricultural systems around the world. We target two questions: (1) What are the taxonomic identities and habitat associations of those bird species that provide pest control in agricultural landscapes, and (2) How does landscape structure modulate avian-mediated pest control? After summarizing what is currently known, we present a conceptual model of the processes and mechanisms that underpin these patterns. We conclude by using this model to identify key research gaps and opportunities within a future research framework to better understand landscape structure effects on avian-mediated pest suppression.

\section{Literature review}

Methods

We conducted a systematic literature review to investigate the role of landscape structure on avian-mediated pest control services in agricultural landscapes. We performed an ISI Web of Science search with keywords (pest* AND (control OR suppression $\mathrm{OR}$ regulation $\mathrm{OR}$ predation $\mathrm{OR}$ reduction $\mathrm{OR}$ insectivory $\mathrm{OR}$ consumption) AND land* AND (bird* OR avian OR farmland OR insectivorous OR predators OR "natural enemies" OR "biological control agent")), with a last view August 2016. A total of 876 papers were returned, of which 62 papers were directly related with pest control and birds in agricultural systems. We examined the references cited for these 62 papers, as well as all peer-reviewed articles that cited one or more of these articles, to arrive at a total of 151 relevant papers (see Table S1). We restricted our focus to agricultural systems, encompassing both perennial and annual plantations. Further, we limited our review to insect agricultural pests, excluding rodents and plant pests (weeds). 
We classified these 151 papers into four classes, those that: (A) highlighted the importance of birds on pest control in agricultural fields without explicit measurements of pest control; (B) reported some measurement of avian-mediated pest control, but without explicitly reporting their links with landscape structure; (C) reported some measurement of pest control by birds and reported links with landscape structure; or (D) used non-empirical data (quantitative meta-analysis, modeling or simulations) to infer pest control by birds (see Table S1).

To understand the identity and habitat association of those bird species involved in pest control in crop fields, we retrieved all papers from categories B and $C$ that reported the identity of avian predators $(n=25)$, commonly through foraging observation, isotopic analysis, camera traps, or DNA barcoding. We used an existing database of bird traits (del Hoyo et al. 2014) to classify these species according their diet and habitat association. For diet, we used five categories: restrictive insectivore (exclusive insect feeders); generalist insectivore (insect feeders that complement their diet with fruits or seeds); occasional insectivore (species that feed predominantly on non-insect resources but occasionally ingest insects); omnivore (that feeds on any available resource including insects, fruits, grains or garbage), or non-insectivore (restrictive granivores, carnivores or frugivores). For habitat association, we classified species as habitat-specialist (species requiring native habitat to persist and/or breed) or habitat-generalists (species able to use both native and anthropogenic habitats).

\section{Results}

The literature linking landscape structure to avian-mediated pest control services is recent, with $85 \%$ of papers $(n=135)$ published within the last decade (Fig. 1). Nearly $60 \%$ of studies $(n=85)$ highlighted the importance of birds to pest suppression in agricultural fields without actual measurements of pest control (paper class A). Over 19\% of studies $(n=29)$ presented empirical evidence of avian-mediated pest suppression without explicit links to landscape structure (class B), while 18\% $(n=27)$ reported similar evidence with explicit links between pest control and landscape structure (class C). Finally, ten papers (3\%) reported results from quantitative meta-analyses or reviews (class D). 


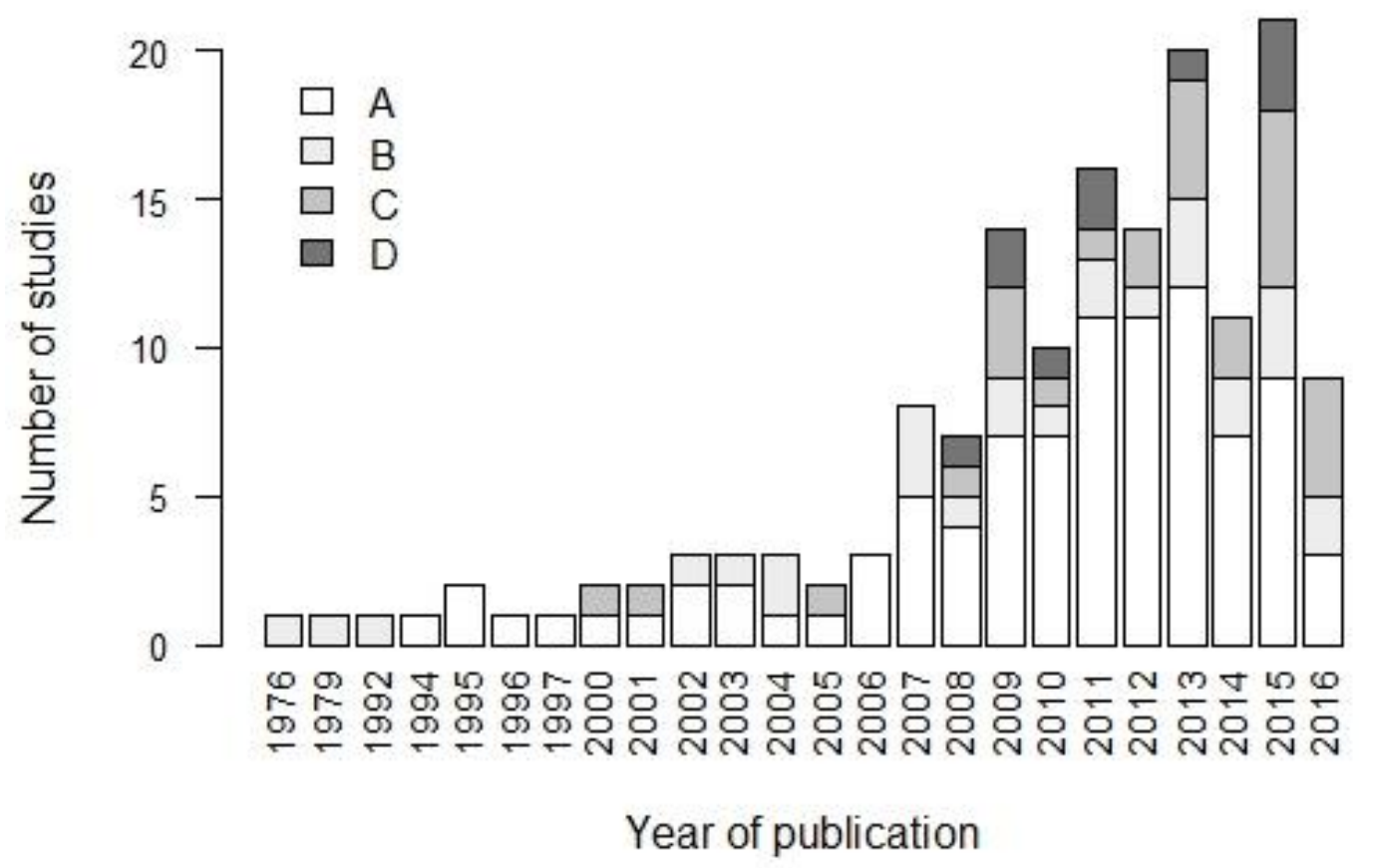

Figure 1. Papers published January 1976 - August 2016 that investigate avian-mediated pest control in agricultural fields. (A) highlighted the importance of birds on pest control in agricultural fields without explicit measurement of pest control ( $\mathrm{n}=85)$; (B) reported some measurement of avian-mediated pest control without explicitly reporting landscape metrics ( $\mathrm{n}=29)$; (C) reported some measurement of pest control by birds and reported landscape metrics associated to this service ( $n=27$ ); or (D) used quantitative meta-analysis, modeling or simulations using a priori empirical evidence to infer pest control by birds $(n=10)$.

Most empirical studies were based in tropical regions and focused on few crop types with correspondingly few pest species (Fig. 2). Tropical studies overwhelmingly focused on control of the coffee borer beetle (Hypothenemus hampei) in coffee plantations, while temperate zone studies predominantly focused on control of the codling moth pest (Cydia pomonella) in apple orchards. Pooling across both regions, $80 \%$ of all studies were conducted in ecosystems originally dominated by forest cover.

\section{Taxonomic correlates and habitat associations}

A total of 226 bird species were identified as providing pest control services (see Table S2). A total of 139 species from 46 families were reported from tropical 
crops, with five families most frequently represented: Parulidae, Turdidae, Muscicapidae, Sturnidae, and Troglodytidae. Another 101 species from 36 families were reported in temperate crops, with the families Icteridae, Parulidae, Emberezidae, Turdidae, and Phasianidae most commonly reported. The majority of avian predators across both regions (69\%) were habitat-generalists. Within tropical studies, $37 \%$ of avian predators reported were habitat-specialists, while $23 \%$ were reported as habitat-specialists in temperate region studies. While the diet of avian predators from both regions was unsurprisingly overwhelmingly insectivorous, we found regional differences in the diet of habitat-specialist species. Restrictive insectivores composed $64 \%$ of tropical habitat-specialists, but only $37 \%$ of temperate habitat-specialists. Even for habitat-generalist species, restrictive insectivory was a more common strategy in tropical than temperate regions (37\% versus 20\% respectively; Fig. 3).
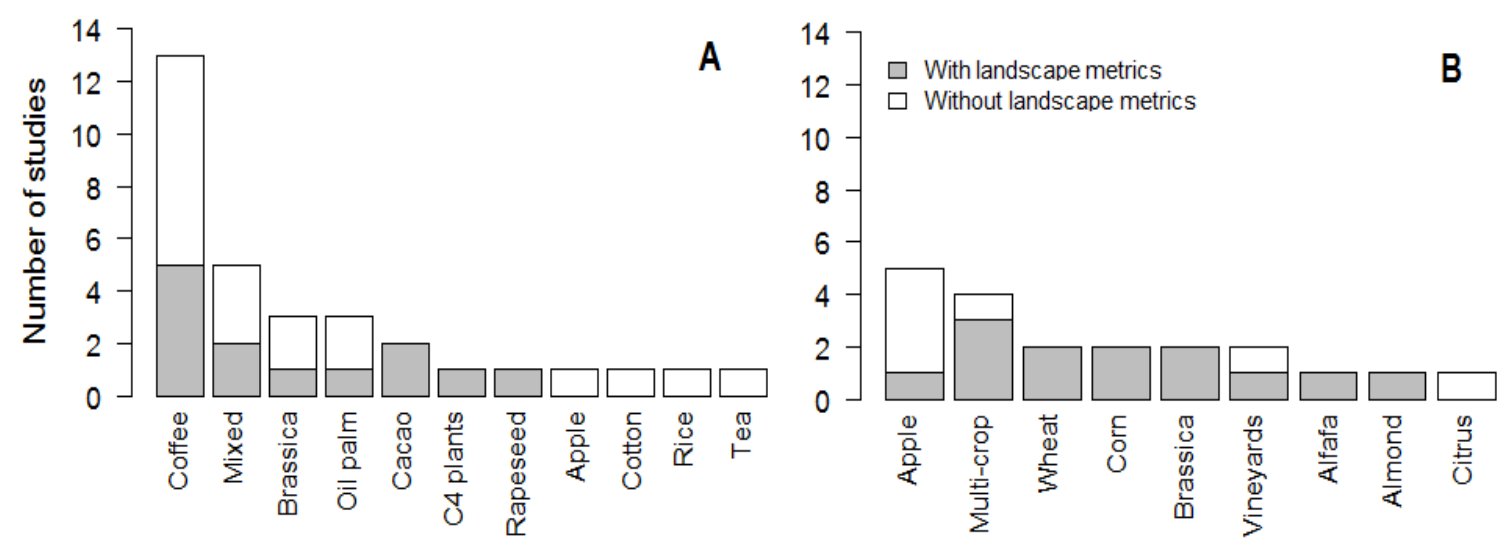

Figure 2. Experimental studies published January 1976 - August $2016(n=56)$ that investigated avian-mediated pest control in different crops. Grey bars show studies that considered the influence of landscape structure on the provision of pest control services, while white bars show studies that did not consider this influence. A: tropical regions, B: temperate regions.

\section{Landscape structure}

Across the 27 studies that considered landscape structure in their evaluation of avian-mediated pest control, the most frequently evaluated landscape features included isolation (i.e. linear distance from the closest native habitat remnant; $\mathrm{n}=$ 14), the areal extent of either native habitat $(n=10)$ or crop cover $(n=3)$, 
landscape composition (i.e. land-use and land-cover proportion or heterogeneity; $\mathrm{n}$ $=4)$, edge density $(n=2)$, and native habitat patch size $(n=1)$.

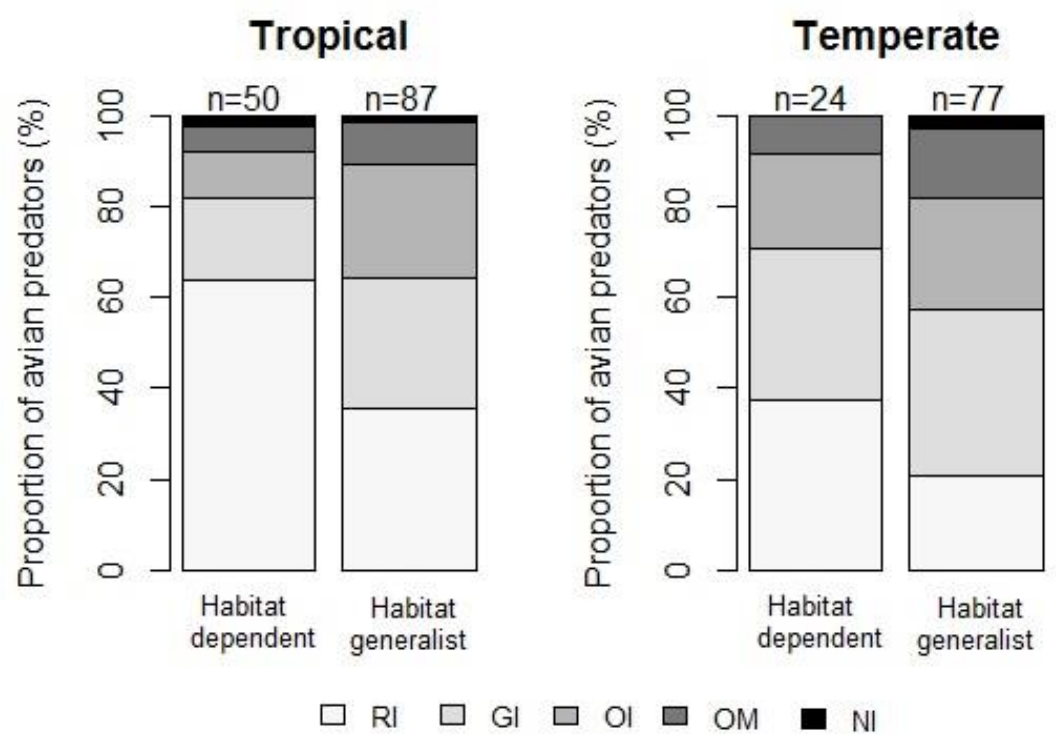

Figure 3. Diet of both native habitat-dependent and habitat-generalist avian predators in tropical and temperate biomes. RI: restrictive insectivores; GI: generalist insectivores; OI: occasional insectivores; OM: omnivores; NI: non-insectivores.

Isolation was reported as having a negative association with avianmediated pest control in $71 \%$ of studies ( $n=10$; Table 1 ). The areal extent of native habitat was frequently reported as positively associated with both avian predator richness and abundance (50\%; $n=5)$, which was subsequently associated with reductions in pest infestation or herbivory in crop fields (Table 1). Two of three studies evaluating landscape heterogeneity reported that compositional heterogeneity (i.e. diversity of both land-use and land-cover types) was positively related with pest suppression. Similarly, two of three studies found that increasing crop extension and homogeneity led to decreased pest suppression. Finally, we found that while few studies evaluated the influence of patch size or edge density $(n=3)$, those that did reported positive relationship between pest control rates and both patch size and edge density (Table 1). 
Table 1. Empirical studies investigating avian-mediated insect pest control that incorporate a landscape perspective in their evaluation. Region. Temperate (Temp); Tropical (Trop). Symbols of the effect of landscape structure in pest control service denote positive (+), negative (-) or neutral effects $(\varnothing)$.

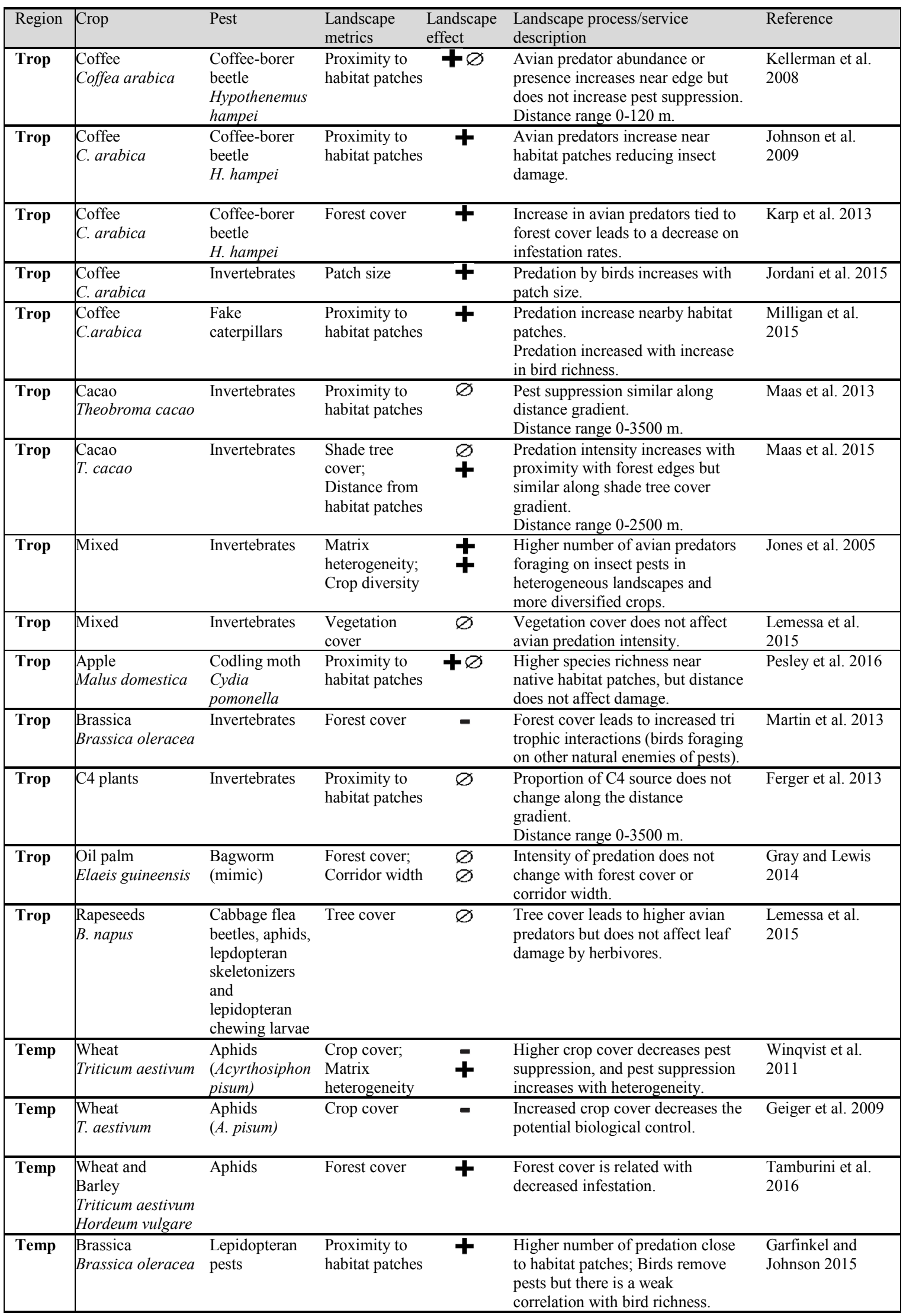




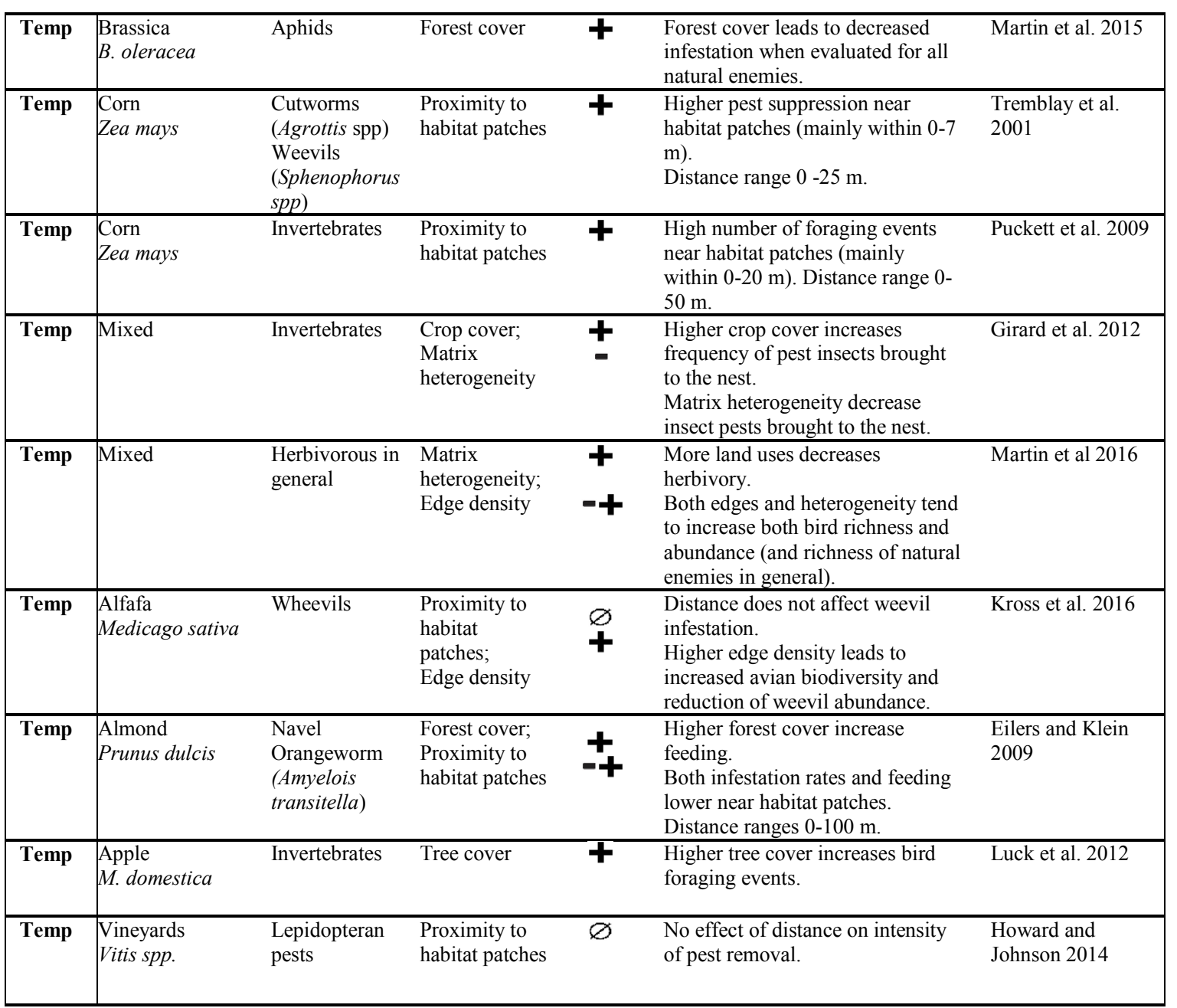

\section{Discussion}

Although more studies are required to better understand how landscape context modulates pest suppression in different crops, some general statements can be made based on our literature review. First, although the majority of avian predators that provide pest-control services are habitat-generalists, a substantial proportion $(\sim 35 \%)$ of avian predators that provide services in tropical regions are habitat-specialists. Most existing studies on avian-mediated pest control are conducted in tropical zones, and consider relatively few crops (main focus in coffee plantations) and/or pest regulation systems, highlighting an urgently need to expansion of research efforts focusing in different crops and systems. Second, multiple aspects of landscape structure appear clearly linked to avian-mediated pest control rates. In general, we found avian-mediated pest suppression to be positively related to land-use heterogeneity, increased native habitat cover, and close proximity to native habitat patches. Identifying how different landscape 
features might enhance avian-mediated pest control is an expanding research area with important implications for landscape planning and management to maintain both biodiversity and ecosystem services provision.

We found that while most avian predators are habitat-generalist species, a substantial proportion of avian predators that provide pest regulation services in the tropics are dependent on native tropical forest habitats. This suggests that conservation of remaining native tropical forests may broadly benefit pestregulation services in agricultural landscapes (Tscharntke et al. 2012). It is important to point out that the identity and species traits of avian predators may matter as much or more to actual service provision than overall richness or abundance per se (Gagic et al. 2015). Even for well-studied systems such as coffee plantations and apple orchards, robust data about the identity of species that provide pest control or the per capita impact on insect pest density is remarkably scare (Letourneau et al. 2009).

Overall, we found that pest suppression by avian predators is often intensified nearby native habitat patches. Authors often attributed this pattern to habitat patches being a source of bird predators (e.g. Kellermann et al. 2008, Johnson et al. 2009, Pesley et al. 2016). Alternatively, predation intensity might be higher near native habitat patches because many forest dependent species avoid crossing long distances of non-habitat (Uezu et al. 2008). For example, Puckett and colleagues observed the majority of avian predators species (76\%) foraging mainly within $20 \mathrm{~m}$ of the woody edge in temperate maize plantations (Puckett et al. 2009). Additionally, Maas and colleagues found higher number of predations marks by birds near forest edges in tropical cacao agroforestry, in an experimental study using plasticine caterpillars (Maas et al. 2015).

Another frequently reported pattern was higher rates avian-mediated pest control in more forested landscapes. This pattern is likely due to the positive impact on avian predator populations provided by larger extents of high quality habitat (Karp et al. 2013, Milligan et al. 2016). This should be particularly important in tropical regions, where approximately 35\% of avian predators are forest-dependent species. In coffee plantations in Costa Rica, Karp and colleagues showed that more forested landscapes had an increased abundance of avian consumers of the coffee borer beetle, as well as lower borer beetle infestation rates 
(Karp et al. 2013). However, we also found evidences that these relationships between native habitat cover and ecosystem services are complex and may be context-dependent (Martin et al. 2013, Martin et al. 2016). For example, Martin and colleagues used exclusion experiments to demonstrate that landscapes with higher natural and semi-natural habitat cover in South Korea may correlate with negative or neutral pest control effects, because avian predators additionally consume insect pest predators that otherwise would have contributed to pest suppression. They reported that in landscapes with more than $25 \%$ of seminatural habitat, crop damage reduction by predator insects was significantly weaker in the presence of avian predators (Martin et al. 2013).

We found that increases in landscape heterogeneity were frequently positively correlated with avian-mediated pest suppression (e.g., Winqvist et al. 2011, Martin et al. 2016). A higher diversity of land-uses or land-covers can promote the persistence of avian predators through enhanced landscape complementation and supplementation processes (see below; Metzger and Brancalion 2016). When landscape heterogeneity was diminished because the areal extent of croplands increased, pest suppression commonly declined (Geiger et al. 2010, Winqvist et al. 2011). For example, in a study across five European regions, decreasing landscape heterogeneity through an increase arable land cover from 20 to $100 \%$ led to a substantial decline in both bird species richness and aphid predation rates (Winqvist et al. 2011). Jones and colleagues (2005) showed that highest abundance of insectivorous birds foraging insects in crop fields was associated with mixed crop plantings (i.e. more heterogeneous matrix land-use) and with the presence of native field borders.

We found relatively few studies that evaluated the impacts of patch size or edge effects on avian-mediated insect pest suppression. Nevertheless, the existing evidence (using dummy caterpillars in coffee plantations in Southern Brazil) suggests that average native habitat patch size positively influences predation intensity (Jordani et al. 2015). Similarly, pest suppression appears intensified in areas of higher edge density (Kross et al. 2016), mainly due to the increase of bird richness and abundance at forest-farm field edges (Kross et al. 2016, Martin et al. 2016). 


\section{A conceptual model of landscape-level avian-mediated pest control}

We propose a new conceptual model to promote further studies on the role of landscape structure on the provisioning of avian-mediated insect pest control services (Fig. 4). This model considers that pest control services in agricultural landscapes fundamentally depend on how landscape structure (i.e. composition and configuration; Column 1 in Fig. 4) will affect landscape-level processes (i.e. those processes that relate two or more landscape units; Column 2, Fig. 4) that ultimately influence mechanisms related to avian-mediated pest control, including: 1) the persistence of avian predators in agricultural habitats; 2) the dispersal ability of avian predators into and through crop fields, and 3) trophic interactions between assemblages of natural enemies and pests (Column 3; Fig. 4). We summarize these main landscape processes and their impacts on pest control outcomes below (Column 4, Fig. 4).

\section{Landscape complementation \& supplementation effects}

Landscape composition and complexity affect the distribution of both avian predators and insect pests, particularly for those species requiring resources dispersed across multiple and distinct habitat patches. This use of resources across multiple habitat patches to either complement or supplement resource access (Dunning et al. 1992), is closely related to avian predator persistence and service provision in agricultural landscapes. Landscape complementation is the capacity of a landscape to provide different resources, usually located in different landscape units or patches (Metzger and Brancalion 2016). For example, avian predators that forage in crop fields may also require hedgerows, habitat strips or forest to roost or breed. Landscape supplementation is a related concept that refers to the capacity of a landscape to provide the same kind of resource, distributed across distinct patches (Metzger and Brancalion 2016). This process is likely to mediate food resource provision for avian predators in agricultural landscapes, for example by when active foraging across multiple fields buffers an avian predator from the negative effects of low prey availability in any given field (Bianchi et al. 2006). These two processes contribute to the frequent observation that more heterogeneous landscapes are able to maintain avian predator abundance and diversity. 


\section{Habitat cover effects}

The amount of native habitat available to a given species (Fahrig 2013) is a central driver of many of the ecological mechanisms proposed to influence avian-mediated pest control (Column 3, Fig. 4). This is because the occurrence and abundance of any given species (including avian predators) should increase with the amount of its preferred habitat (Villard and Metzger 2014). Additionally, higher amounts of native habitat increase landscape connectivity, which increases the accessibility of even small fragments that are situated in landscapes with high native habitat coverage (Fahrig 2013). Despite providing avian predators and increasing landscape connectivity, an increase in habitat amount (up to a certain level) also leads to an increase in landscape heterogeneity. These native habitat patches despite providing habitat-dependent predators, they are also important for those habitat-generalist predators, providing a huge variety of resources yearlong (i.e. landscape supplementation and complementation). Some studies, however, have demonstrated that this increase on landscape heterogeneity besides influence positively pest suppression, can also leads to neutral or negative effects (Letourneau et al. 2009, Martin et al. 2013) related to an increase on complexity of natural enemies assemblages and potential changes in trophic interactions.

\section{Edge \& cross-habitat spillover effects}

Edge effects can be defined as the mutual influences of adjacent landscape units (Villard and Metzger 2014). Native habitat patches can act as sources of avian predators that influence adjacent landscape units (e.g. crop fields) as a result of cross-habitat spillover (Tscharntke et al. 2012). We could expect that an increase in edge density (i.e. increased contact between crop and native habitat units) increases the probability that native habitat-dependent avian predators spill over from native habitats into crop fields (Mitchell et al. 2015, Boesing et al. In prep). In addition, larger extents of native habitat that supports avian predators should allow greater predator movement into crop fields where the pest control is provided. Cross-habitat spillover seems to occur mainly in more forested landscapes ( $>30 \%$ of forest cover; Estavillo et al. 2013), and may therefore be an especially important edge process in tropical regions, where around 35\% of described avian predators are habitat-dependent species. Increasing distance from 
native habitat edge is associated with both reduced spillover (Tscharntke et al. 2008a) and reduced predation intensity because these areas can provide more resources to avian predators (Johnson et al. 2009, Puckett et al. 2009) or because they can facilitate the dispersal of those species in the landscape (Metzger 2000). The matrix composition seems play an important role driving dispersal and spill over processes as the capacity of different edge types to facilitate movement will likely vary according the structure of adjacent land uses (i.e. matrix) and the biological features of the focal species. Further, the spillover of avian predators from natural habitats into neighboring crop fields may also affect trophic interactions and its directions through changes on assemblages of natural enemies (Martin et al. 2013).

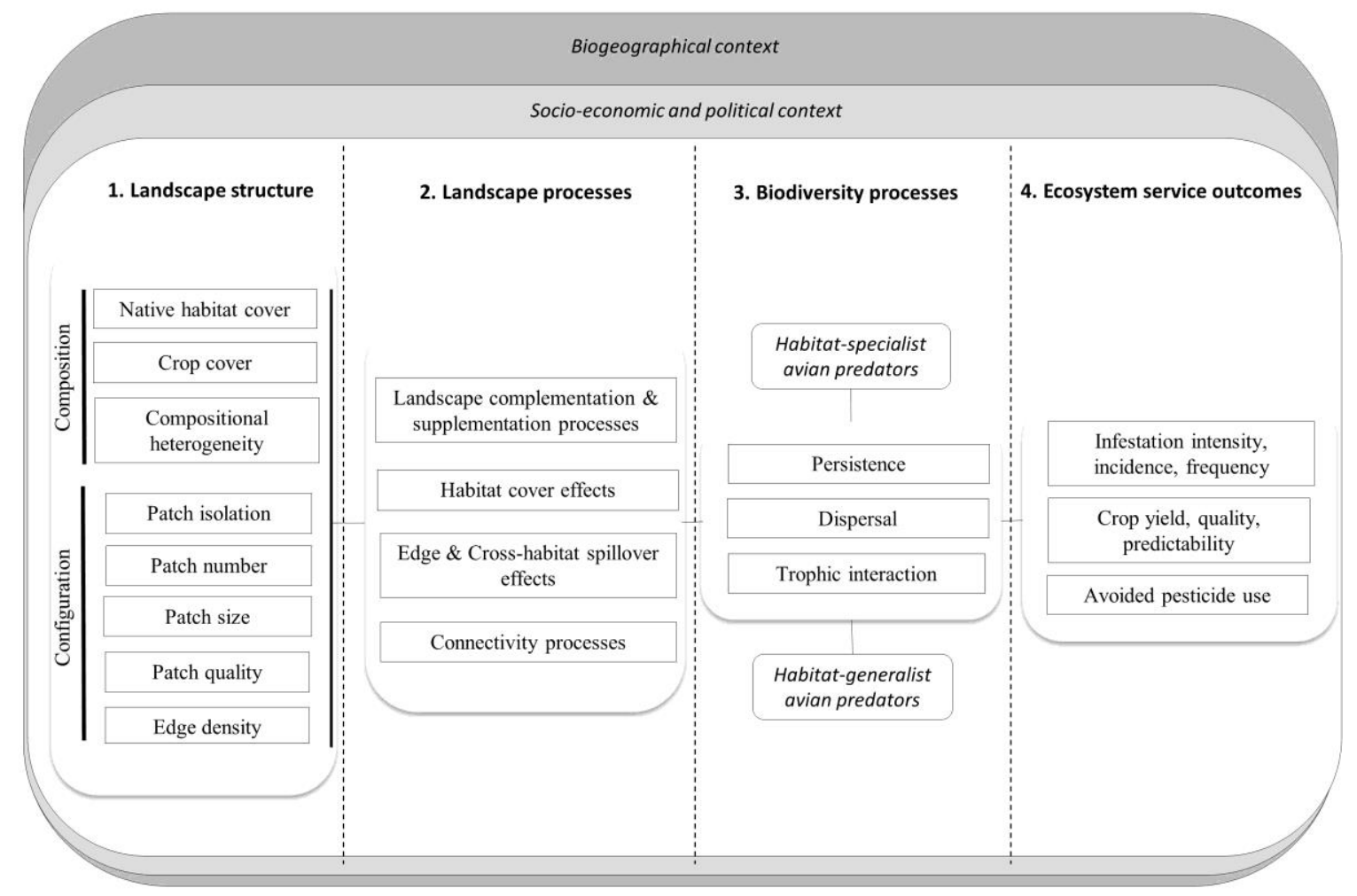

Figure 4. Conceptual model showing multiple mechanisms by which landscape structure can modulate avian-mediated insect pest control services. Provision of pest control services in agricultural landscapes (Column 4) depends on how landscape structure (i.e. composition and configuration; Column 1) will affect landscape processes (i.e. processes that link two or more landscape units; Column 2) and associated ecological mechanisms that regulate pest control, including: 1) the persistence of avian predators in agricultural environments; 2) the dispersal ability of avian predators into and through crop fields, and 3) trophic interactions between the entire assemblage of natural enemies and pests (Column 3). 


\section{Connectivity processes}

Landscape connectivity is defined as the capacity of landscape to facilitate the movement of organisms (Taylor et al. 1993). Both landscape configuration and composition strongly influence connectivity (Belisle et al. 2001), and consequently, influences how avian predators disperse through agricultural landscapes (Villard and Metzger 2014). Individual landscape units such as trees, hedgerows or windbreaks may act as stepping-stones (Boscolo et al. 2008, Uezu et al. 2008, Robertson and Radford 2009) that facilitate the movement of avian predators moving from native patches to agricultural areas. In addition, matrix types that are more permeable (i.e. structurally more similar to native habitat patches) often increase inter-patch colonization rates (Prevedello and Vieira 2010) by positively influencing avian movement across the matrix (Ricketts 2001, Driscoll et al. 2013). However, functional connectivity depends not only on the structural characteristics of the landscape, but also on the species-specific dispersal ability of the species under consideration (Gascon et al. 1999).

\section{Opportunities for future research}

Several processes operating at the landscape-level appear to mediate the interactions between landscape structure and avian-mediated pest control. We need to understand how both these processes operate individually and how they interact to contribute to pest control to improve landscape management for enhanced avian-mediated pest control, and predict synergisms and tradeoffs in ecosystem services provision. We identified three main gaps for future investigations of the relationships between landscape structure and avianmediated pest control services.

1. How does landscape structure affect trophic interactions related to avianmediated pest control?

Interactions among diverse enemy assemblages may lead to negative, neutral or positive consequences for ecosystem functioning (Finke and Denno 2004, Tylianakis and Romo 2010). We cannot predict these directions without knowing the identity of species interacting and their role within trophic chains. Most studies measure 'biodiversity' of natural enemies in the simple metrics of 
species richness or abundance (Garfinkel and Johnson 2015, Martin et al. 2016), without reference to either the habitat associations of these species or their functional traits related to pest control provision. We need to improve our understanding of how landscape processes affect key trophic interactions and influence the representation of relevant functional traits, considering the effects of habitat amount, landscape heterogeneity, and cross-habitat spillover processes. Some experimental studies adding and removing predators (e.g. Martin et al. 2013) are a good way to start the achievement of this understanding. Investigations about the landscape effects modulating trophic chains in agricultural landscapes is a flourishing field of investigation which will allow us understand the directions of these interactions and contribute to design and manage multi-functional landscapes.

\section{Can increasing landscape heterogeneity increase the attractiveness of crop fields to} avian predators to promote pest control service delivery?

High landscape compositional heterogeneity can enhance landscape complementation processes, and can thus contribute to more diversified avian predator communities, with likely positive effects on pest control. At the same time, as landscapes with more heterogeneous configurations have higher edge density, the positive benefits of heterogeneity may be offset by the costs of lower rates of those processes contingent on large extents of native habitat, including cross-habitat spillover and functional connectivity. Different mechanisms can thus be involved in the relationship between landscape heterogeneity and pest control depending on if we consider the compositional or configurational component of heterogeneity (Fahrig et al. 2011). Furthermore, this heterogeneity can be enhanced by considering either natural landscape units (including those across a spectrum of disturbance or successional stage) or alternatively by considering more anthropogenic units (e.g. different matrix types, including crops, fallow fields, and urban or semi-urban areas).Which of those heterogeneity components (composition or configuration) and units (more native or more anthropogenic land uses) more effectively modulate pest control? An expanded effort to investigate these questions in different crop systems, considering heterogeneity in composition and configuration, within native or matrix landscape units, and using 
different focal avian predators is needed. Experimental approaches capable of clarifying causal relationships between landscape heterogeneity and pest control processes are particularly welcome, for example using predator enrichment approaches such as hunting perches, intercropping additional resources (Jones and Sieving 2006), or installing nest boxes to attract birds to breeding and foraging in the matrix (Mols and Visser 2002). These efforts could be efficient ways to understand which component of the landscape heterogeneity is important to enhance the potential pest reduction services by avian predators.

3. How does landscape structure facilitate the cross-habitat spillover of habitatdependent avian predators to crop fields?

In those contexts where a significant portion of the avian predator community that provides pest control services is composed by native habitatspecialists, cross-habitat spillover from native to agricultural habitats should be a key feature of any agricultural landscape management strategy. However, we know surprisingly little about what elements of landscape design will best promote spillover. Are relevant spillover processes mediated by the amount of edge, or type of edge contrast between native and agricultural patches? Or is spillover mediated instead by the relative degree of agricultural matrix permeability, by the size of habitat patches, or the areal extent of agricultural fields? Do specific species of functionally important avian predators avoid gap crossing, or have other behavioral barriers (Harris and Reed 2002) that require assessment? Careful future studies that consider both landscape structural characteristics and the species-specific behaviors, and pest control contributions of the avian predators in questions will be required to tease out the relative contributions of specific species identity from more general principals regarding the influence of landscape-level structure on avian-mediated insect pest regulation.

\section{Concluding remarks}

Our review identifies a series of key landscape factors that positively contribute to avian-mediated pest control: high landscape heterogeneity, higher habitat amount, and enhanced landscape connectivity. Moreover, we found that most avian species 
providing pest control services in agricultural ecosystems are habitat generalists, but a considerable proportion of habitat dependent species might provide pest control services in tropical regions. Based on our findings, our conceptual model for linking landscape structure to avian pest control highlights the role of four key landscape processes: landscape supplementation and complementation, native habitat cover effects, edge and cross-habitat spillover effects and landscape connectivity. Given the limited number and biased distribution of studies across regions and crops, an expansion of research efforts identifying avian predators, understanding trophic interactions, and clarifying predator movement patterns across the crop/non-crop interface will be required to make stronger generalizations about the influence landscape structure on the efficacy of avianmediated pest control, and contributions of landscape design to sustainable and multi-functional landscapes.

\section{Acknowledgments}

This study was developed within the "Interface Project", supported by São Paulo Research Foundation (FAPESP, 2013/23457-6). A.L.B was supported by doctoral fellowships from the Brazilian Ministry of Education (CAPES-DS; 2012-2013), and São Paulo Research Foundation (FAPESP) (2013/12777-0). E.N. was supported by post-doctoral fellowships from the National Science Foundation grant (1158817) and the São Paulo Research Foundation (FAPESP) (2014/11676-8). J.P.M. was funded by National Council for Scientific and Technological Development (CNPQ, process number: 307934/2011-0). We are grateful to J.A. Prevedello, G. Bravo, R. F. dos Santos, Christopher Whelan, Clive McAlpine, and an anonymous referee for substantial improvement in the earlier version of the manuscript.

\section{Literature cited}

Andren, H. 1994. Effects of habitat fragmentation in birds and mammals in landscapes with different proportions of suitable habitat - a review. Oikos 71:355-366.

Asner, G. P., A. J. Elmore, L. P. Olander, R. E. Martin, and A. T. Harris. 2004. Grazing systems, ecosystem responses, and global change. Annual Review of Environment and Resources 29:261-299. 
Banks-Leite, C., R. Pardini, L. R. Tambosi, W. D. Pearse, A. A. Bueno, R. T. Bruscagin, T. H. Condez, M. Dixo, A. T. Igari, A. C. Martensen, and J. P. Metzger. 2014. Using ecological thresholds to evaluate the costs and benefits of set-asides in a biodiversity hotspot. Science 345:1041-1045.

Barnosky, A. D., N. Matzke, S. Tomiya, G. O. U. Wogan, B. Swartz, T. B. Quental, C. Marshall, J. L. McGuire, E. L. Lindsey, K. C. Maguire, B. Mersey, and E. A. Ferrer. 2011. Has the Earth's sixth mass extinction already arrived? Nature 471:51-57.

Belisle, M., A. Desrochers, and M. J. Fortin. 2001. Influence of forest cover on the movements of forest birds: A homing experiment. Ecology 82:1893-1904.

Betts, M. G., G. J. Forbes, and A. W. Diamond. 2007. Thresholds in songbird occurrence in relation to landscape structure. Conservation Biology 21:1046-1058.

Bianchi, F. J. J. A., C. J. H. Booij, and T. Tscharntke. 2006. Sustainable pest regulation in agricultural landscapes: a review on landscape composition, biodiversity and natural pest control. Proceedings of the Royal Society B-Biological Sciences 273:1715-1727.

Blitzer, E. J., C. F. Dormann, A. Holzschuh, A.-M. Klein, T. A. Rand, and T. Tscharntke. 2012. Spillover of functionally important organisms between managed and natural habitats. Agriculture Ecosystems \& Environment 146:34-43.

Boesing, A. L., E. Nichols, and J. P. Metzger. In prep. How does landscape structure affects avian cross-habitat spillover?

Bommarco, R., D. Kleijn, and S. G. Potts. 2013. Ecological intensification: harnessing ecosystem services for food security. Trends in Ecology \& Evolution 28:230-238.

Bommarco, R., F. Miranda, H. Bylund, and C. Bjorkman. 2011. Insecticides Suppress Natural Enemies and Increase Pest Damage in Cabbage. Journal of Economic Entomology 104:782-791.

Bonning, B. C. and N. P. Chougule. 2014. Delivery of intrahemocoelic peptides for insect pest management. Trends in Biotechnology 32:91-98.

Boscolo, D., C. Candia-Gallardo, M. Awade, and J. P. Metzger. 2008. Importance of interhabitat gaps and stepping-stones for lesser woodcreepers (Xiphorhynchus fuscus) in the Atlantic forest, Brazil. Biotropica 40:273-276.

Bregman, T. P., C. H. Sekercioglu, and J. A. Tobias. 2014. Global patterns and predictors of bird species responses to forest fragmentation: Implications for ecosystem function and conservation. Biological Conservation 169:372-383.

Burkey, T. V. 1995. Extinction rates in archipelagoes - implications for populations in fragmented habitats. Conservation Biology 9:527-541. 
Cardinale, B. J., J. E. Duffy, A. Gonzalez, D. U. Hooper, C. Perrings, P. Venail, A. Narwani, G. M. Mace, D. Tilman, D. A. Wardle, A. P. Kinzig, G. C. Daily, M. Loreau, J. B. Grace, A. Larigauderie, D. S. Srivastava, and S. Naeem. 2012. Biodiversity loss and its impact on humanity. Nature 486:59-67.

DeClerck, F., N. Estrada-Carmona, K. Garbach, and A. Martinez-Salinas. 2015. Biodiversity and Ecosystem Services of Agricultural Landscapes: reversing agriculture's externalities. Pages 140-157 Agroecology for Food Security and Nutrition Proceedings of the FAO International Symposium. FAO, Rome, Italy.

del Hoyo, J., A. Elliott, J. Sargatal, D. A. Christie, and E. Juana. 2014. Handbook of the Birds of the World Alive. Linx Edicions, Barcelons.

Dirzo, R. and P. H. Raven. 2003. Global state of biodiversity and loss. Annual Review of Environment and Resources 28:137-167.

Driscoll, D. A., S. C. Banks, P. S. Barton, D. B. Lindenmayer, and A. L. Smith. 2013. Conceptual domain of the matrix in fragmented landscapes. Trends in Ecology \& Evolution 28:605-613.

Dunning, J. B., B. J. Danielson, and H. R. Pulliam. 1992. Ecological processes that affect populations in complex landscapes. Oikos 65:169-175.

Estavillo, C., R. Pardini, and P. L. Bernardo da Rocha. 2013. Forest Loss and the Biodiversity Threshold: An Evaluation Considering Species Habitat Requirements and the Use of Matrix Habitats. Plos One 8.

Fahrig, L. 1997. Relative effects of habitat loss and fragmentation on population extinction. Journal of Wildlife Management 61:603-610.

Fahrig, L. 1998. When does fragmentation of breeding habitat affect population survival? Ecological Modelling 105:273-292.

Fahrig, L. 2002. Effect of habitat fragmentation on the extinction threshold: A synthesis. Ecological Applications 12:346-353.

Fahrig, L. 2003. Effects of habitat fragmentation on biodiversity. Annual Review of Ecology Evolution and Systematics 34:487-515.

Fahrig, L. 2013. Rethinking patch size and isolation effects: the habitat amount hypothesis. Journal of Biogeography 40:1649-1663.

Fahrig, L., J. Baudry, L. Brotons, F. G. Burel, T. O. Crist, R. J. Fuller, C. Sirami, G. M. Siriwardena, and J.-L. Martin. 2011. Functional landscape heterogeneity and animal biodiversity in agricultural landscapes Ecology Letters 14:101-112.

Ficetola, G. F. and M. Denoel. 2009. Ecological thresholds: an assessment of methods to identify abrupt changes in species-habitat relationships. Ecography 32:1075-1084. 
Finke, D. L. and R. F. Denno. 2004. Predator diversity dampens trophic cascades. Nature 429:407-410.

Foley, J. A., R. DeFries, G. P. Asner, C. Barford, G. Bonan, S. R. Carpenter, F. S. Chapin, M. T. Coe, G. C. Daily, H. K. Gibbs, J. H. Helkowski, T. Holloway, E. A. Howard, C. J. Kucharik, C. Monfreda, J. A. Patz, I. C. Prentice, N. Ramankutty, and P. K. Snyder. 2005. Global consequences of land use. Science 309:570-574.

Frishkoff, L. O., D. S. Karp, L. K. M'Gonigle, C. D. Mendenhall, J. Zook, C. Kremen, E. A. Hadly, and G. C. Daily. 2014. Loss of avian phylogenetic diversity in neotropical agricultural systems. Science 345:1343-1346.

Gagic, V., I. Bartomeus, T. Jonsson, A. Taylor, C. Winqvist, C. Fischer, E. M. Slade, I. SteffanDewenter, M. Emmerson, S. G. Potts, T. Tscharntke, W. Weisser, and R. Bommarco. 2015. Functional identity and diversity of animals predict ecosystem functioning better than species-based indices. Proceedings of the Royal Society B-Biological Sciences $\mathbf{2 8 2}$.

Garfinkel, M. and M. Johnson. 2015. Pest-removal services provided by birds on small organic farms in northern California. Agriculture Ecosystems \& Environment 211:24-31.

Gascon, C., T. E. Lovejoy, R. O. Bierregaard, J. R. Malcolm, P. C. Stouffer, H. L. Vasconcelos, W. F. Laurance, B. Zimmerman, M. Tocher, and S. Borges. 1999. Matrix habitat and species richness in tropical forest remnants. Biological Conservation 91:223-229.

Geiger, F., J. Bengtsson, F. Berendse, W. W. Weisser, M. Emmerson, M. B. Morales, P. Ceryngier, J. Liira, T. Tscharntke, C. Winqvist, S. Eggers, R. Bommarco, T. Part, V. Bretagnolle, M. Plantegenest, L. W. Clement, C. Dennis, C. Palmer, J. J. Onate, I. Guerrero, V. Hawro, T. Aavik, C. Thies, A. Flohre, S. Hanke, C. Fischer, P. W. Goedhart, and P. Inchausti. 2010. Persistent negative effects of pesticides on biodiversity and biological control potential on European farmland. Basic and Applied Ecology 11:97-105.

Grassini, P., K. M. Eskridge, and K. G. Cassman. 2013. Distinguishing between yield advances and yield plateaus in historical crop production trends. Nature Communications 4.

Haddad, N. M. 2015. Corridors for people, corridors for nature. Science 350:1166-1167.

Haddad, N. M., L. A. Brudvig, E. I. Damschen, D. M. Evans, B. L. Johnson, D. J. Levey, J. L. Orrock, J. Resasco, L. L. Sullivan, J. J. Tewksbury, S. A. Wagner, and A. J. Weldon. 2014. Potential Negative Ecological Effects of Corridors. Conservation Biology 28:1178-1187. 
Haila, Y. 2002. A conceptual genealogy of fragmentation research: From island biogeography to landscape ecology. Ecological Applications 12:321-334.

Harris, R. J. and J. M. Reed. 2002. Behavioral barriers to non-migratory movements of birds. Annales Zoologici Fennici 39:275-290.

Hooper, D. U., F. S. Chapin, J. J. Ewel, A. Hector, P. Inchausti, S. Lavorel, J. H. Lawton, D. M. Lodge, M. Loreau, S. Naeem, B. Schmid, H. Setala, A. J. Symstad, J. Vandermeer, and D. A. Wardle. 2005. Effects of biodiversity on ecosystem functioning: A consensus of current knowledge. Ecological Monographs 75:3-35.

Jarzyna, M. A. and W. Jetz. 2016. Detecting the multiple facets if biodiversity. Trends in Ecology \& Evolution:In press.

Jirinec, V., B. R. Campos, and M. D. Johnson. 2011. Roosting behaviour of a migratory songbird on Jamaican coffee farms: landscape composition may affect delivery of an ecosystem service. Bird Conservation International 21:353-361.

Johnson, M. D., N. J. Levy, J. L. Kellermann, and D. E. Robinson. 2009. Effects of shade and bird exclusion on arthropods and leaf damage on coffee farms in Jamaica's Blue Mountains. Agroforestry Systems 76:139-148.

Jones, G. A. and K. E. Sieving. 2006. Intercropping sunflower in organic vegetables to augment bird predators of arthropods. Agriculture Ecosystems \& Environment 117:171-177.

Jordani, M. X., E. Hasui, and V. Silva. 2015. Natural enemies depend on remnant habitat size in agricultural landscapes. Journal of Forestry Research 26:469-477.

Jordano, P. 2016. Chasing ecological interactions. Plos Biology 14:1-4.

Jules, E. S. and P. Shahani. 2003. A broader ecological context to habitat fragmentation: Why matrix habitat is more important than we thought. Journal of Vegetation Science 14:459-464.

Karp, D. S., C. D. Mendenhall, R. F. Sandi, N. Chaumont, P. R. Ehrlich, E. A. Hadly, and G. C. Daily. 2013. Forest bolsters bird abundance, pest control and coffee yield. Ecology Letters 16:1339-1347.

Kellermann, J. L., M. D. Johnson, A. M. Stercho, and S. C. Hackett. 2008. Ecological and Economic Services Provided by Birds on Jamaican Blue Mountain Coffee Farms. Conservation Biology 22:1177-1185.

Kremen, C., N. M. Williams, M. A. Aizen, B. Gemmill-Herren, G. LeBuhn, R. Minckley, L. Packer, S. G. Potts, T. a. Roulston, I. Steffan-Dewenter, D. P. Vazquez, R. Winfree, L. Adams, E. E. Crone, S. S. Greenleaf, T. H. Keitt, A.-M. Klein, J. Regetz, and T. H. Ricketts. 2007. Pollination and other ecosystem services produced by mobile 
organisms: a conceptual framework for the effects of land-use change. Ecology Letters 10:299-314.

Kross, S. M., T. R. Kelsey, C. J. McColl, and J. M. Townsend. 2016. Field-scale habitat complexity enhances avian conservation and avian-mediated pest-control services in an intensive agricultural crop. Agriculture Ecosystems \& Environment 225:140149.

Kupfer, J. A., G. P. Malanson, and S. B. Franklin. 2006. Not seeing the ocean for the islands: the mediating influence of matrix-based processes on forest fragmentation effects. Global Ecology and Biogeography 15:8-20.

Laxminarayan, R. and R. D. Simpson. 2000. Biological limits on agricultural intensification: an example from resistance management. Resources for the Nature, Washington, DC.

Letourneau, D. K., J. A. Jedlicka, S. G. Bothwell, and C. R. Moreno. 2009. Effects of Natural Enemy Biodiversity on the Suppression of Arthropod Herbivores in Terrestrial Ecosystems. Annual Review of Ecology Evolution and Systematics 40:573-592.

Levey, D. J., B. M. Bolker, J. J. Tewksbury, S. Sargent, and N. M. Haddad. 2005. Effects of landscape corridors on seed dispersal by birds. Science 309:146-148.

Losey, J. E. and M. Vaughan. 2006. The economic value of ecological services provided by insects. Bioscience 56:311-323.

Maas, B., Y. Clough, and T. Tscharntke. 2013. Bats and birds increase crop yield in tropical agroforestry landscapes. Ecology Letters 16:1480-1487.

Maas, B., T. Tscharntke, S. Saleh, D. D. Putra, and Y. Clough. 2015. Avian species identity drives predation success in tropical cacao agroforestry. Journal of Applied Ecology 52:735-743.

Martin, E. A., B. Reineking, B. Seo, and I. Steffan-Dewenter. 2013. Natural enemy interactions constrain pest control in complex agricultural landscapes. Proceedings of the National Academy of Sciences of the United States of America 110:5534-5539.

Martin, E. A., B. Seo, C. R. Park, B. Reineking, and I. Steffan-Dewenter. 2016. Scaledependent effects of landscape composition and configuration on natural enemy diversity, crop herbivory, and yields. Ecological Applications 26:448-462.

Matson, P. A., W. J. Parton, A. G. Power, and M. J. Swift. 1997. Agricultural intensification and ecosystem properties. Science 277:504-509.

MEA. 2005. Millennium Ecosystem Assessment Synthesis, United Nations.

Metzger, J. P. 2000. Tree functional group richness and spatial structure in a tropical fragmented landscape (SE Brazil). Ecological Applications 10:1147-1161. 
Metzger, J. P. and P. H. S. Brancalion. 2016. Landscape ecology and restoration processes. Pages 90-120 in M. A. Palmer, J. B. Zeller, and D. A. Falk, editors. Foundation of restoration ecology. Island Press, Washington, DC.

Milligan, M. C., M. D. Johnson, M. Garfinkel, C. J. Smith, and P. Njoroge. 2016. Quantifying pest control services by birds and ants in Kenyan coffee farms. Biological Conservation 194:58-65.

Mitchell, M. G. E., A. F. Suarez-Castro, M. Martinez-Harms, M. Maron, C. McAlpine, K. J. Gaston, K. Johansen, and J. R. Rhodes. 2015. Reframing landscape fragmentation's effects on ecosystem services. Trends in Ecology \& Evolution 30:190-198.

Mokross, K., T. B. Ryder, M. C. Cortes, J. D. Wolfe, and P. C. Stouffer. 2014. Decay of interspecific avian flock networks along a disturbance gradient in Amazonia. Proceedings of the Royal Society B-Biological Sciences 281.

Mols, C. M. M. and M. E. Visser. 2002. Great tits can reduce caterpillar damage in apple orchards. Journal of Applied Ecology 39:888-899.

Mooney, K. A., D. S. Gruner, N. A. Barber, S. A. Van Bael, S. M. Philpott, and R. Greenberg. 2010. Interactions among predators and the cascading effects of vertebrate insectivores on arthropod communities and plants. Proceedings of the National Academy of Sciences of the United States of America 107:7335-7340.

Naeem, S., J. E. Duffy, and E. Zavaleta. 2012. The Functions of Biological Diversity in an Age of Extinction. Science 336:1401-1406.

Oerke, E. C. 2006. Crop losses to pests. Journal of Agricultural Science 144:31-43.

Oliver, T. H., N. J. B. Isaac, T. A. August, B. A. Woodcock, D. B. Roy, and J. M. Bullock. 2015. Declining resilience of ecosystem functions under biodiversity loss. Nature Communications 6.

Ostman, O., B. Ekbom, and J. Bengtsson. 2001. Landscape heterogeneity and farming practice influence biological control. Basic and Applied Ecology 2:365-371.

Pardini, R., A. D. Bueno, T. A. Gardner, P. I. Prado, and J. P. Metzger. 2010. Beyond the Fragmentation Threshold Hypothesis: Regime Shifts in Biodiversity Across Fragmented Landscapes. Plos One 5.

Pesley, R. K., M. E. Saunders, and G. W. Luck. 2016. Cost-benefit trade-offs of bird activity in apple orchards. Peerj:1-20.

Pimm, S. L., G. J. Russell, J. L. Gittleman, and T. M. Brooks. 1995. The future of biodiversity. Science 269:347-350.

Prevedello, J. A., N. Gotelli, and J. P. Metzger. In press. A stochastic model for landscape patterns of biodiversity. Ecological Monographs. 
Prevedello, J. A. and M. V. Vieira. 2010. Does the type of matrix matter? A quantitative review of the evidence. Biodiversity and Conservation 19:1205-1223.

Puckett, H. L., J. R. Brandle, R. J. Johnson, and E. E. Blankenship. 2009. Avian foraging patterns in crop field edges adjacent to woody habitat. Agriculture Ecosystems \& Environment 131:9-15.

Ramankutty, N. and J. A. Foley. 1999. Estimating historical changes in global land cover: Croplands from 1700 to 1992. Global Biogeochemical Cycles 13:997-1027.

Richmond, S., E. Jenkins, A. Couturier, and M. Cadman. 2015. Thresholds in forest bird richness in response to three types of forest cover in Ontario, Canada. Landscape Ecology 30:1273-1290.

Ricketts, T. H. 2001. The matrix matters: Effective isolation in fragmented landscapes. American Naturalist 158:87-99.

Robertson, 0. J. and J. Q. Radford. 2009. Gap-crossing decisions of forest birds in a fragmented landscape. Austral Ecology 34:435-446.

Schellhorn, N. A., S. Macfadyen, F. J. J. A. Bianchi, D. G. Williams, and M. P. Zalucki. 2008. Managing ecosystem services in broadacre landscapes: what are the appropriate spatial scales? Australian Journal of Experimental Agriculture 48:1549-1559.

Sekercioglu, C. H. 2006. Foreword on the ecological significance of bird populations Pages 15-51 in J. Del Hoyo, A. Elliott, and D. A. Christie, editors. Handbook of birds of the world. Lynx Edicions, Barcelona.

Sekercioglu, C. H., D. G. Wenny, and C. J. Whelan. 2016. Why birds matter: avian ecological function and ecosystem services. The University of Chicago Press, Chicago, London.

Steffen, W., K. Richardson, J. Rockstrom, S. E. Cornell, I. Fetzer, E. M. Bennett, R. Biggs, S. R. Carpenter, W. de Vries, C. A. de Wit, C. Folke, D. Gerten, J. Heinke, G. M. Mace, L. M. Persson, V. Ramanathan, B. Reyers, and S. Sorlin. 2015. Planetary boundaries: Guiding human development on a changing planet. Science 347.

Taylor, P. D., L. Fahrig, K. Henein, and G. Merriam. 1993. Connectivity is a vital element of landscape structure. Oikos 68:571-573.

TEEB. 2010. Mainstreaming the Economics of Nature: A Synthesis of the Approach, Conclusions and Recommendations of TEEB.in S. P., W. H., S.-S. C., N. C., B. J., B. Pt., G. H., K. P., and S. B., editors. Conference of Parties to the CBD, Nagoya, Japan.

Tscharntke, T., R. Bommarco, Y. Clough, T. O. Crist, D. Kleijn, T. A. Rand, J. M. Tylianakis, S. van Nouhuys, and S. Vidal. 2007. Conservation biological control and enemy diversity on a landscape scale. Biological Control 43:294-309.

Tscharntke, T., R. Bommarco, Y. Clough, T. O. Crist, D. Kleijn, T. A. Rand, J. M. Tylianakis, S. van Nouhuys, and S. Vidal. 2008a. Conservation biological control and enemy 
diversity on a landscape scale (Reprinted from Biol. Control, vol 43, pg 294-309, 2007). Biological Control 45:238-253.

Tscharntke, T., A. M. Klein, A. Kruess, I. Steffan-Dewenter, and C. Thies. 2005. Landscape perspectives on agricultural intensification and biodiversity - ecosystem service management. Ecology Letters 8:857-874.

Tscharntke, T., C. H. Sekercioglu, T. V. Dietsch, N. S. Sodhi, P. Hoehn, and J. M. Tylianakis. 2008b. Landscape constraints on functional diversity of birds and insects in a tropical agroecosystem (vol 89, pg 944, 2008). Ecology 89.

Tscharntke, T., J. M. Tylianakis, T. A. Rand, R. K. Didham, L. Fahrig, P. Batary, J. Bengtsson, Y. Clough, T. O. Crist, C. F. Dormann, R. M. Ewers, J. Frund, R. D. Holt, A. Holzschuh, A. M. Klein, D. Kleijn, C. Kremen, D. A. Landis, W. Laurance, D. Lindenmayer, C. Scherber, N. Sodhi, I. Steffan-Dewenter, C. Thies, W. H. van der Putten, and C. Westphal. 2012. Landscape moderation of biodiversity patterns and processes eight hypotheses. Biological Reviews 87:661-685.

Turner, M. G., D. C. Donato, and W. H. Romme. 2013. Consequences of spatial heterogeneity for ecosystem services in changing forest landscapes: priorities for future research. Landscape Ecology 28:1081-1097.

Tylianakis, J. M. and C. M. Romo. 2010. Natural enemy diversity and biological control: Making sense of the context-dependency. Basic and Applied Ecology 11:657-668.

Uezu, A., D. D. Beyer, and J. P. Metzger. 2008. Can agroforest woodlots work as stepping stones for birds in the Atlantic Forest region? . Biodiversity and Conservation 17:1907-1922.

Van Bael, S. A., S. M. Philpott, R. Greenberg, P. Bichier, N. A. Barber, K. A. Mooney, and D. S. Gruner. 2008. Birds as predators in tropical agroforestry systems. Ecology 89:928934.

Villard, M.-A. and J. P. Metzger. 2014. Beyond the fragmentation debate: a conceptual model to predict when habitat configuration really matters. Journal of Applied Ecology 51:309-318.

Webb, C. O. 2000. Exploring the phylogenetic structure of ecological communities: An example for rain forest trees. American Naturalist 156:145-155.

Whelan, C. J., D. G. Wenny, and R. J. Marquis. 2008. Ecosystem services provided by birds. Year in Ecology and Conservation Biology 2008 1134:25-60.

Winqvist, C., J. Bengtsson, T. Aavik, F. Berendse, L. W. Clement, S. Eggers, C. Fischer, A. Flohre, F. Geiger, J. Liira, T. Paert, C. Thies, T. Tscharntke, W. W. Weisser, and R. Bommarco. 2011. Mixed effects of organic farming and landscape complexity on 
farmland biodiversity and biological control potential across Europe. Journal of Applied Ecology 48:570-579.

Wu, J. 2013. Landscape sustainability science: ecosystem services and human well-being in changing landscapes. . Landscape Ecology 28:999-1023. 


\section{Supplementary material}

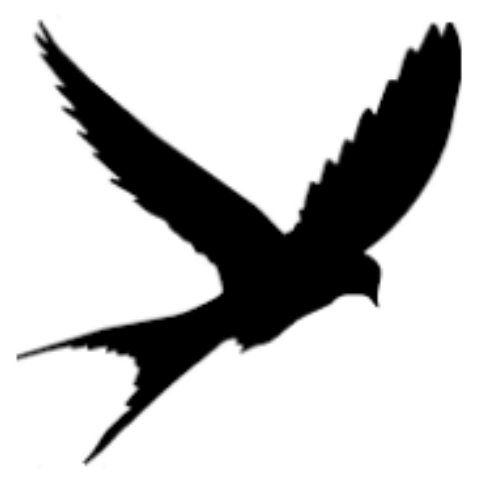


Table S1: List of 151 papers found in the literature review according the study category: (A) highlighted the importance of birds on pest control in agricultural fields without explicit measurements of pest control; (B) reported some measurements of avian-mediated pest control without explicitly reporting their links with the landscape structure; (C) reported some measurements of pest control by birds and reported the links with landscape metrics; or (D) used non-empirical data (quantitative meta-analysis, modeling or simulations) to infer pest control by birds.

\begin{tabular}{|c|c|c|c|c|}
\hline Class & Author & Biome & Crop & Landscape metrics \\
\hline $\mathrm{D}$ & Maas et al.2015 & review & review & review \\
\hline $\mathrm{D}$ & Mantyla et al. 2011 & review & agricultural and natural areas & review \\
\hline $\mathrm{D}$ & Mooney et al. 2010 & review & agricultural and natural areas & review \\
\hline $\mathrm{D}$ & Pesley et al. 2015 & review & review & review \\
\hline $\mathrm{D}$ & Philphot et al. 2009 & tropical & coffee & review \\
\hline $\mathrm{D}$ & Pumarinõ et al. 2015 & review & review & review \\
\hline $\mathrm{D}$ & Railsback \& Johson 2011 & review & review & review \\
\hline $\mathrm{D}$ & Railsback \& Johson 2014 & review & review & review \\
\hline $\mathrm{D}$ & Van Bael et al. 2008 & tropical-temperate & agroforests & review \\
\hline $\mathrm{D}$ & Vickery et al. 2009 & review & review & review \\
\hline $\mathrm{C}$ & Eilers \& Klein 2009 & temperate & almond orchard & habitat cover + edge distance \\
\hline $\mathrm{C}$ & Ferger et al. 2013 & tropical & C4 plants & distance \\
\hline $\mathrm{C}$ & Garfinkel and Johnson 2014 & temperate & brassica & distance \\
\hline $\mathrm{C}$ & Geiger et al. 2010 & temperate & mainly wheat & landscape composition (\% land use) \\
\hline $\mathrm{C}$ & Girard 2012 & temperate & corn, weat (mixed) & landscape composition (\% land use) \\
\hline $\mathrm{C}$ & Gray and Lewis 2014 & tropical & oil palm & habitat cover/corridor width \\
\hline $\mathrm{C}$ & Howard \& Johnson 2014 & temperate & vineyards & distance \\
\hline $\mathrm{C}$ & Johnson et al. 2009 & tropical & coffee & $\begin{array}{l}\text { landscape composition (\% land use) + edge } \\
\text { distance }\end{array}$ \\
\hline
\end{tabular}




\begin{tabular}{|c|c|c|c|c|}
\hline $\mathrm{C}$ & Jones et al. 2005 & tropical & mixed crops & landscape composition (\% land use) \\
\hline $\mathrm{C}$ & Jordani et al. 2015 & tropical & coffee & patch size (6-105.9ha) \\
\hline $\mathrm{C}$ & Karp et al. 2013 & tropical & coffee & habitat cover \\
\hline $\mathrm{C}$ & Kellerman et al. 2008 & tropical & coffee & distance \\
\hline $\mathrm{C}$ & Kross et al. 2016 & temperate & alfalfa & no \\
\hline $\mathrm{C}$ & Lemessa et al. $2015 \mathrm{~b}$ & tropical & rapeseeds & tree cover \\
\hline $\mathrm{C}$ & Lemessa et al.2015a & tropical & homegardens & habitat cover \\
\hline $\mathrm{C}$ & Luck et al. 2012 & temperate & apple orchards & tree cover \\
\hline $\mathrm{C}$ & Maas et al.2013 & tropical & cacao & $\begin{array}{l}\text { distance } \\
\text { shade tree cover and distance from forest }\end{array}$ \\
\hline $\mathrm{C}$ & Maas et al. 2015 & tropical & cacao & remnant \\
\hline $\mathrm{C}$ & Martin et al. 2013 & tropical & brassica & habitat cover \\
\hline $\mathrm{C}$ & Martin et al. 2015 & temperate & brassica & $\begin{array}{l}\text { habitat cover } \\
\text { composition (land uses), habitat amount, Edge }\end{array}$ \\
\hline $\mathrm{C}$ & Martin et al. 2016 & temperate & mixed crops & density \\
\hline $\mathrm{C}$ & Milligan 2016 & tropical & coffee & distance \\
\hline $\mathrm{C}$ & Pesley et al. 2016 & savanna, tropical & apple orchards & distance \\
\hline $\mathrm{C}$ & Puckett et al. 2009 & temperate & corn & distance \\
\hline $\mathrm{C}$ & Tamburini 2016 & temperate & wheat and barley & habitat cover ( 1.2 to $22 \%$ ) \\
\hline $\mathrm{C}$ & Tremblay et al. 2001 & temperate & corn & distance \\
\hline $\mathrm{C}$ & Winqvist et al. 2011 & temperate & weat & landscape composition (\% land use) \\
\hline B & Borkhataria et al. 2006 & tropical & coffee & - \\
\hline B & Borkhataria et al. 2012c & tropical & rice & - \\
\hline B & Chenon \& Sunsanto 2009 & tropical & oil palm & - \\
\hline B & Classen 2014 & tropical & $\begin{array}{l}\text { coffee } \\
\text { shelterbelts adjacent mixed }\end{array}$ & - \\
\hline B & Gamez-Virues 2007 & tropical & crops and pastures & - \\
\hline B & Greenberg et al. 2000 & tropical & coffee & - \\
\hline B & Hooks et al. 2003 & tropical & brassica & - \\
\hline
\end{tabular}


King et al. 2015

Koh et al. 2008

Mols \& Visser 2002

Mols \& Visser 2007

Ndang'ang'a et al. 2013a

Ndang'ang'a et al. 2013b

Orlowski et al. 2015

Perfecto et al. 2004

Peters \& Greenberg 2013

Philphot et al. 2004

Pinol et al. 2010

Sanchez-Zapata et al. 2007

Saunders and Luck 2016

Sinu 2011

Solomon \& Glen 1976

Solomon \& Glen 1979

Wearing \& MacCarthy 1992

tropical
temperate
tropical
tropical
tropical
temperate
tropical
temperate
temperate
tropical
tropical
temperate
tropical
tropical
tropical
temperate
arid
savanna, tropical
tropical
temperate
temperate
tropical
-
-
-
-
-
-

cotton

vineyards

coffee

agroforests

coffee

reedbeds

oil palm

apple orchards

apple orchards

mixed crops

brassica

multicrops

coffee

coffee

coffee

citrus grove

multicrops

apple orchards

tea

apple orchards

apple orchards

apple orchards

Anderson et al. 2007

Bailey et al. 2010

Barbaro \& Battisti 2011

Barbaro et al. 2014

Barbaro et al. 2012

Batary et al. 2010 
Beecher 2002

Beenhower et al. 2013

Bianchi et al. 2006

Bisseaua 2013

Blaauw \& Isaacs 2015

Blommers et al. 1994

Borkataria et al. 2012a

Borkataria et al. 2012b

Bradbury et al. 2010

Buechley et al. 2015

Charles-Bouvier et al. 2011

Clough et al. 2011

Clough et al. 2009

Colding \& Folke 2009

Dale \& Polasky 2007

DeClerck et al. 2010

Deikumah et al. 2013

Develey \& Pongiluppi 2010

Dix et al. 1995

Edwards et al. 2014

Evenden 1995

Evans-Ogden 2007

Fisher et al. 2010

Flynn et al. 2009

Gavier-Pizarro et al. 2012

Gojiman et al. 2015

Green \& Elmberg 2014

Haslam et al. 2002 


Hernandez et al. 2013
Jacobson et al. 2003
Jedlika et al. 2013
Jirinic et al. 2011
Jobin et al. 2001
Karp et al. 2011
Karp et al. 2012
Karpa et al. 2015
Kirk 1996
Komar et al. 2006
Landis et al.2000
Laterneou et al. 2009
Luck 2013
Luck et al. 2015
Luck et al. 2013
Luck et al. 2009
Lundberg \& Moberg 2003
Martin et al. 2012
Mulwa et al. 2012
Munoz et al.2013
Myczko et al. 2013
Newbold et al.2014
Perfecto et al.2007
Philpott 2008
Philpott \& Bichier 2012
Pimentel 1997
Poceda et al. 2008
Poch \& Simoneti 2013


Power 2010

Prabowo et al. 2016

Rush et al. 2014

Rush et al. 2016

Sagoff et al. 2011

Sarwar et al. 2016

Sauders et al. 2015

Schackermann et al. 2015

Sekercioglu 2012

Sekercioglu 2006

Sekercioglu 2004

Thompson et al. 2014

Thuiller et al. 2014

Triplet et al. 2012

Tscharntke et al.2008

Tscharntke et al.2011

Tscharntke et al. 2005

Tschumi et al. 2015

Wenny et al. 2011

Werling et al. 2014

Whelan et al. 2008

Wilsey et al. 2011

Zhang et al. 2007

\section{Literature review}


Andersson, E., S. Barthel, and K. Ahrne. 2007. Measuring social-ecological dynamics behind the generation of ecosystem services. Ecological Applications 17:1267-1278.

Bailey, D., M. H. Schmidt-Entling, P. Eberhart, J. D. Herrmann, G. Hofer, U. Kormann, and F. Herzog. 2010. Effects of habitat amount and isolation on biodiversity in fragmented traditional orchards. Journal of Applied Ecology 47:1003-1013.

Barbaro, L. and A. Battisti. 2011. Birds as predators of the pine processionary moth (Lepidoptera: Notodontidae). Biological Control 56:107-114.

Barbaro, L., E. G. Brockerhoff, B. Giffard, and I. van Halder. 2012. Edge and area effects on avian assemblages and insectivory in fragmented native forests. Landscape Ecology 27:1451-1463.

Barbaro, L., B. Giffard, Y. Charbonnier, I. van Halder, and E. G. Brockerhoff. 2014. Bird functional diversity enhances insectivory at forest edges: a transcontinental experiment. Diversity and Distributions 20:149-159.

Batary, P., T. Matthiesen, and T. Tscharntke. 2010. Landscape-moderated importance of hedges in conserving farmland bird diversity of organic vs. conventional croplands and grasslands. Biological Conservation 143:2020-2027.

Beecher, N. A., R. J. Johnson, J. R. Brandle, R. M. Case, and L. J. Young. 2002. Agroecology of birds in organic and nonorganic farmland. Conservation Biology 16:1620-1631.

Bianchi, F. J. J. A., C. J. H. Booij, and T. Tscharntke. 2006. Sustainable pest regulation in agricultural landscapes: a review on landscape composition, biodiversity and natural pest control. Proceedings of the Royal Society B-Biological Sciences 273:1715-1727.

Bisseleua, H. B. D., D. Fotio, Yede, A. D. Missoup, and S. Vidal. 2013. Shade Tree Diversity, Cocoa Pest Damage, Yield Compensating Inputs and Farmers' Net Returns in West Africa. Plos One 8.

Blaauw, B. R. and R. Isaacs. 2015. Wildflower plantings enhance the abundance of natural enemies and their services in adjacent blueberry fields. Biological Control 91:94-103.

Blommers, L. H. M. 1994. Integrated Pest-Management in European Apple Orchards. Annual Review of Entomology 39:213-241.

Borkhataria, R., J. A. Collazo, M. J. Groom, and A. Jordan-Garcia. 2012a. Shade-grown coffee in Puerto Rico: Opportunities to preserve biodiversity while reinvigorating a struggling agricultural commodity. Agriculture Ecosystems \& Environment 149:164-170. 
Borkhataria, R. R., J. A. Collazo, and M. J. Groom. 2006. Additive effects of vertebrate predators on insects in a Puerto Rican coffee plantation. Ecological Applications 16:696-703.

Borkhataria, R. R., J. A. Collazo, and M. J. Groom. 2012b. Species abundance and potential biological control services in shade vs. sun coffee in Puerto Rico. Agriculture Ecosystems \& Environment 151:1-5.

Borkhataria, R. R., G. S. Nuessly, E. Pearlstine, and R. H. Cherry. 2012c. Effects of Blackbirds (Agelaius Phoenicius) on Stink Bug (Hemiptera: Pentatomidae) Populations, Damage, and Yield in Florida Rice. Florida Entomologist 95:143-149.

Bouvier, J. C., B. Ricci, J. Agerberg, and C. Lavigne. 2011. Apple Orchard Pest Control Strategies Affect Bird Communities in Southeastern France. Environmental Toxicology and Chemistry 30:212-219.

Bradbury, R. B., C. Stoate, and J. R. B. Tallowin. 2010. Lowland farmland bird conservation in the context of wider ecosystem service delivery. Journal of Applied Ecology 47:986-993.

Buechley, E. R., C. H. Sekercioglu, A. Atickem, G. Gebremichael, J. K. Ndungu, B. A. Mahamued, T. Beyene, T. Mekonnen, and L. Lens. 2015. Importance of Ethiopian shade coffee farms for forest bird conservation. Biological Conservation 188:50-60.

Chenon, R. D. and A. Susanto. 2006. Ecological observations on diurnal birds in Indonesian oil palm plantations. Journal of Oil Palm Research:122143.

Classen, A., M. K. Peters, S. W. Ferger, M. Helbig-Bonitz, J. M. Schmack, G. Maassen, M. Schleuning, E. K. V. Kalko, K. Bohning-Gaese, and I. SteffanDewenter. 2014. Complementary ecosystem services provided by pest predators and pollinators increase quantity and quality of coffee yields. Proceedings of the Royal Society B-Biological Sciences 281.

Clough, Y., J. Barkmann, J. Juhrbandt, M. Kessler, T. C. Wanger, A. Anshary, D. Buchori, D. Cicuzza, K. Darras, D. D. Putra, S. Erasmi, R. Pitopang, C. Schmidt, C. H. Schulze, D. Seidel, I. Steffan-Dewenter, K. Stenchly, S. Vidal, M. Weist, A. C. Wielgoss, and T. Tscharntke. 2011. Combining high biodiversity with high yields in tropical agroforests. Proceedings of the National Academy of Sciences of the United States of America 108:8311-8316. 
Clough, Y., D. D. Putra, R. Pitopang, and T. Tscharntke. 2009. Local and landscape factors determine functional bird diversity in Indonesian cacao agroforestry. Biological Conservation 142:1032-1041.

Colding, J. and C. Folke. 2009. The Role of Golf Courses in Biodiversity Conservation and Ecosystem Management. Ecosystems 12:191-206.

Dale, V. H. and S. Polasky. 2007. Measures of the effects of agricultural practices on ecosystem services. Ecological Economics 64:286-296.

De Beenhouwer, M., R. Aerts, and O. Honnay. 2013. A global meta-analysis of the biodiversity and ecosystem service benefits of coffee and cacao agroforestry. Agriculture Ecosystems \& Environment 175:1-7.

DeClerck, F. A. J., R. Chazdon, K. D. Holl, J. C. Milder, B. Finegan, A. Martinez-Salinas, P. Imbach, L. Canet, and Z. Ramos. 2010. Biodiversity conservation in human-modified landscapes of Mesoamerica: Past, present and future. Biological Conservation 143:2301-2313.

Deikumah, J. P., C. A. McAlpine, and M. Maron. 2013. Matrix Intensification Alters Avian Functional Group Composition in Adjacent Rainforest Fragments. Plos One 8.

Develey, P. F. and T. Pongiluppi. 2010. Potential impacts of the changes proposed in the Brazilian Forest Code on birds. Biota Neotropica 10:43-45.

Dix, M. E., R. J. Johnson, M. O. Harrell, R. M. Case, R. J. Wright, L. Hodges, J. R. Brandle, M. M. Schoeneberger, N. J. Sunderman, R. L. Fitzmaurice, and L. J. Young. 1995. Influences of Trees on Abundance of Natural Enemies of Insect Pests - a Review. Agroforestry Systems 29:303-311.

Edwards, F. A., D. P. Edwards, S. Sloan, and K. C. Hamer. 2014. Sustainable Management in Crop Monocultures: The Impact of Retaining Forest on Oil Palm Yield. Plos One 9.

Eilers, E. J. and A. M. Klein. 2009. Landscape context and management effects on an important insect pest and its natural enemies in almond. Biological Control 51:388-394.

Evans-Ogden, L. J., D. B. Lank, and S. Bittman. 2007. Use of agricultural land by shorebirds in the Fraser River Delta. Canadian Journal of Plant Science 87:528-529.

Evenden, M. D. 1995. The labors of Nature: Economic ornithology and the role of birds as agents of biological pest control in North American agriculture, ca 1880-1930. Forest \& Conservation History 39:172-183. 
Ferger, S. W., K. Bohning-Gaese, W. Wilcke, Y. Oelmann, and M. Schleuning. 2013. Distinct carbon sources indicate strong differentiation between tropical forest and farmland bird communities. Oecologia 171:473-486.

Fischer, J., A. Zerger, P. Gibbons, J. Stott, and B. S. Law. 2010. Tree decline and the future of Australian farmland biodiversity. Proceedings of the National Academy of Sciences of the United States of America 107:19597-19602.

Flynn, D. F. B., M. Gogol-Prokurat, T. Nogeire, N. Molinari, B. T. Richers, B. B. Lin, N. Simpson, M. M. Mayfield, and F. DeClerck. 2009. Loss of functional diversity under land use intensification across multiple taxa. Ecology Letters 12:22-33.

Gamez-Virues, S., R. S. Bonifacio, G. M. Gurr, C. Kinross, A. Raman, and H. I. Nicol. 2007. Arthropod prey of shelterbelt-associated birds: linking faecal samples with biological control of agricultural pests. Australian Journal of Entomology 46:325-331.

Garfinkel, M. and M. Johnson. 2015. Pest-removal services provided by birds on small organic farms in northern California. Agriculture Ecosystems \& Environment 211:24-31.

Gavier-Pizarro, G. I., N. C. Calamari, J. J. Thompson, S. B. Canavelli, L. M. Solari, J. Decarre, A. P. Goijman, R. P. Suarez, J. N. Bernardos, and M. E. Zaccagnini. 2012. Expansion and intensification of row crop agriculture in the Pampas and Espinal of Argentina can reduce ecosystem service provision by changing avian density. Agriculture Ecosystems \& Environment 154:44-55.

Geiger, F., J. Bengtsson, F. Berendse, W. W. Weisser, M. Emmerson, M. B. Morales, P. Ceryngier, J. Liira, T. Tscharntke, C. Winqvist, S. Eggers, R. Bommarco, T. Part, V. Bretagnolle, M. Plantegenest, L. W. Clement, C. Dennis, C. Palmer, J. J. Onate, I. Guerrero, V. Hawro, T. Aavik, C. Thies, A. Flohre, S. Hanke, C. Fischer, P. W. Goedhart, and P. Inchausti. 2010. Persistent negative effects of pesticides on biodiversity and biological control potential on European farmland. Basic and Applied Ecology 11:97-105.

Girard, J., A. Baril, P. Mineau, and L. Fahrig. 2012. Foraging habitat and diet of Song Sparrows (Melospiza melodia) nesting in farmland: a stable isotope approach. Canadian Journal of Zoology-Revue Canadienne De Zoologie 90:1339-1350.

Goijman, A. P., M. J. Conroy, J. N. Bernardos, and M. E. Zaccagnini. 2015. Multi-Season Regional Analysis of Multi-Species Occupancy: Implications for Bird Conservation in Agricultural Lands in East-Central Argentina. Plos One 10. 
Graya, C. L. and O. T. Lewis. 2014. Do riparian forest fragments provide ecosystem services or disservices in surrounding oil palm plantations? Basic and Applied Ecology 15:693-700.

Green, A. J. and J. Elmberg. 2014. Ecosystem services provided by waterbirds. Biological Reviews 89:105-122.

Greenberg, R., P. Bichier, A. C. Angon, C. MacVean, R. Perez, and E. Cano. 2000. The impact of avian insectivory on arthropods and leaf damage in some Guatemalan coffee plantations. Ecology 81:1750-1755.

Haslam, S. M. and A. Vella. 2002. Birds associated with agricultural crops in Malta. Avian Landscape Ecology: Pure and Applied Issues in the LargeScale Ecology of Birds:238-241.

Hernandez, S. M., B. J. Mattsson, V. E. Peters, R. J. Cooper, and C. R. Carroll. 2013. Coffee Agroforests Remain Beneficial for Neotropical Bird Community Conservation across Seasons. Plos One 8.

Hooks, C. R. R., R. R. Pandey, and M. W. Johnson. 2003. Impact of avian and arthropod predation on lepidopteran caterpillar densities and plant productivity in an ephemeral agroecosystem. Ecological Entomology 28:522-532.

Howard, K. A. and M. D. Johnson. 2014. Effects of natural habitat on pest control in california vineyards. Western Birds 45:276-283.

Howe, A. G., G. Nachman, and G. L. Lovei. 2015. Predation pressure in Ugandan cotton fields measured by a sentinel prey method. Entomologia Experimentalis Et Applicata 154:161-170.

Jacobson, S. K., K. E. Sieving, G. A. Jones, and A. Van Doorn. 2003. Assessment of farmer attitudes and behavioral intentions toward bird conservation on organic and conventional Florida farms. Conservation Biology 17:595-606.

Jedlicka, J. A., R. Greenberg, and D. K. Letourneau. 2011. Avian Conservation Practices Strengthen Ecosystem Services in California Vineyards. Plos One 6.

Jedlika, J. A., A. M. Sharma, and R. P. P. Almeida. 2013. Molecular tools reveal diets of insectivorous birds from predator fecal matter. Conservation Genetics Resources 5:879-885.

Jirinec, V., B. R. Campos, and M. D. Johnson. 2011. Roosting behaviour of a migratory songbird on Jamaican coffee farms: landscape composition may affect delivery of an ecosystem service. Bird Conservation International 21:353-361. 
Jobin, B., L. Choiniere, and L. Belanger. 2001. Bird use of three types of field margins in relation to intensive agriculture in Quebec, Canada. Agriculture Ecosystems \& Environment 84:131-143.

Johnson, M. D., J. L. Kellermann, and A. M. Stercho. 2010. Pest reduction services by birds in shade and sun coffee in Jamaica. Animal Conservation 13:140-147.

Johnson, M. D., N. J. Levy, J. L. Kellermann, and D. E. Robinson. 2009. Effects of shade and bird exclusion on arthropods and leaf damage on coffee farms in Jamaica's Blue Mountains. Agroforestry Systems 76:139-148.

Jones, G. A. and K. E. Sieving. 2006. Intercropping sunflower in organic vegetables to augment bird predators of arthropods. Agriculture Ecosystems \& Environment 117:171-177.

Jones, G. A., K. E. Sieving, and S. K. Jacobson. 2005. Avian diversity and functional insectivory on north-central Florida farmlands. Conservation Biology 19:1234-1245.

Jordani, M. X., E. Hasui, and V. Silva. 2015. Natural enemies depend on remnant habitat size in agricultural landscapes. Journal of Forestry Research 26:469-477.

Karp, D. S. and G. C. Daily. 2014. Cascading effects of insectivorous birds and bats in tropical coffee plantations. Ecology 95:1065-1074.

Karp, D. S., C. D. Mendenhall, R. F. Sandi, N. Chaumont, P. R. Ehrlich, E. A. Hadly, and G. C. Daily. 2013. Forest bolsters bird abundance, pest control and coffee yield. Ecology Letters 16:1339-1347.

Karp, D. S., A. J. Rominger, J. Zook, J. Ranganathan, P. R. Ehrlich, and G. C. Daily. 2012. Intensive agriculture erodes beta-diversity at large scales. Ecology Letters 15:963-970.

Karp, D. S., G. Ziv, J. Zook, P. R. Ehrlich, and G. C. Daily. 2011. Resilience and stability in bird guilds across tropical countryside. Proceedings of the National Academy of Sciences of the United States of America 108:21134-21139.

Karpa, D. S., C. D. Mendenhall, E. Callaway, L. O. Frishkoff, P. M. Kareiva, P. R. Ehrlich, and G. C. Daily. 2015. Confronting and resolving competing values behind conservation objectives. Proceedings of the National Academy of Sciences of the United States of America 112:11132-11137. 
Kellermann, J. L., M. D. Johnson, A. M. Stercho, and S. C. Hackett. 2008. Ecological and Economic Services Provided by Birds on Jamaican Blue Mountain Coffee Farms. Conservation Biology 22:1177-1185.

King, R. A., W. O. C. Symondson, and R. J. Thomas. 2015. Molecular analysis of faecal samples from birds to identify potential crop pests and useful biocontrol agents in natural areas. Bulletin of Entomological Research 105:261-272.

King, W. B. 1980. Ecological basis of extinction in birds. Acta Congressus Internationalis Ornithologici 2:905-911.

Kirk, A. 1996. Past and current attempts to evaluate the role of birds as predators of insect pests in temperate agriculture. Current Ornithology 13:175-269.

Koh, L. P. 2008. Birds defend oil palms from herbivorous insects. Ecological Applications 18:821-825.

Komar, O. 2006. Ecology and conservation of birds in coffee plantations: a critical review. Bird Conservation International 16:1-23.

Kross, S. M., T. R. Kelsey, C. J. McColl, and J. M. Townsend. 2016. Field-scale habitat complexity enhances avian conservation and avian-mediated pestcontrol services in an intensive agricultural crop. Agriculture Ecosystems \& Environment 225:140-149.

Landis, D. A., S. D. Wratten, and G. M. Gurr. 2000. Habitat management to conserve natural enemies of arthropod pests in agriculture. Annual Review of Entomology 45:175-201

Lemessa, D., P. A. Hamback, and K. Hylander. 2015a. Arthropod but Not Bird Predation in Ethiopian Homegardens Is Higher in Tree-Poor than in Tree-Rich Landscapes. Plos One 10.

Lemessa, D., U. Samnegard, P. A. Hamback, and K. Hylander. 2015b. Tree cover mediates the effect on rapeseed leaf damage of excluding predatory arthropods, but in an unexpected way. Agriculture Ecosystems \& Environment 211:57-64.

Letourneau, D. K., J. A. Jedlicka, S. G. Bothwell, and C. R. Moreno. 2009. Effects of Natural Enemy Biodiversity on the Suppression of Arthropod Herbivores in Terrestrial Ecosystems. Annual Review of Ecology Evolution and Systematics 40:573-592.

Luck, G. W. 2013. The net return from animal activity in agroecosystems: trding off benefits from ecosystem services against costs from crop damage. F1000 Research 2:1-20. 
Luck, G. W., A. Carter, and L. Smallbone. 2013. Changes in Bird Functional Diversity across Multiple Land Uses: Interpretations of Functional Redundancy Depend on Functional Group Identity. Plos One 8.

Luck, G. W., R. Harrington, P. A. Harrison, C. Kremen, P. M. Berry, R. Bugter, T. P. Dawson, F. de Bello, S. Diaz, C. K. Feld, J. R. Haslett, D. Hering, A. Kontogianni, S. Lavorel, M. Rounsevell, M. J. Samways, L. Sandin, J. Settele, M. T. Sykes, S. van den Hove, M. Vandewalle, and M. Zobel. 2009. Quantifying the Contribution of Organisms to the Provision of Ecosystem Services. Bioscience 59:223-235.

Luck, G. W., K. Hunt, and A. Carter. 2015. The species and functional diversity of birds in almond orchards, apple orchards, vineyards and eucalypt woodlots. Emu 115:99-109.

Luck, G. W., S. Lavorel, S. McIntyre, and K. Lumb. 2012. Improving the application of vertebrate trait-based frameworks to the study of ecosystem services. Journal of Animal Ecology 81:1065-1076.

Lundberg, J. and F. Moberg. 2003. Mobile link organisms and ecosystem functioning: Implications for ecosystem resilience and management. Ecosystems 6:87-98.

Maas, B., Y. Clough, and T. Tscharntke. 2013. Bats and birds increase crop yield in tropical agroforestry landscapes. Ecology Letters 16:1480-1487.

Maas, B., D. S. Karp, S. Bumrungsri, K. Darras, D. Gonthier, J. C. C.-. HUang, C. A. Lindell, J. J. Maine, L. Mestre, N. L. Michel, E. B. Morrinson, I. Prerfecto, S. Philpott, C. H. Sekercioglu, R. M. Silva, P. J. Taylor, T. Tscharntke, S. A. Van Bael, C. J. Whelan, and K. Willians-Guillén. 2015a. Bird and bat predation services in tropical forests and agroforestry landscapes. Biological Reviews:1-21.

Maas, B., T. Tscharntke, S. Saleh, D. D. Putra, and Y. Clough. 2015b. Avian species identity drives predation success in tropical cacao agroforestry. Journal of Applied Ecology 52:735-743.

Mantyla, E., T. Klemola, and T. Laaksonen. 2011. Birds help plants: a meta-analysis of top-down trophic cascades caused by avian predators. Oecologia 165:143-151.

Martin, E. A., B. Reineking, B. Seo, and I. Steffan-Dewenter. 2013. Natural enemy interactions constrain pest control in complex agricultural landscapes. Proceedings of the National Academy of Sciences of the United States of America 110:5534-5539. 
Martin, E. A., B. Reineking, B. Seo, and I. Steffan-Dewenter. 2015. Pest control of aphids depends on landscape complexity and natural enemy interactions. Peerj 3.

Martin, E. A., B. Seo, C. R. Park, B. Reineking, and I. Steffan-Dewenter. 2016. Scale-dependent effects of landscape composition and configuration on natural enemy diversity, crop herbivory, and yields. Ecological Applications 26:448-462.

Martin, E. A., M. Viano, L. Ratsimisetra, F. Laloe, and S. M. Carriere. 2012. Maintenance of bird functional diversity in a traditional agroecosystem of Madagascar. Agriculture Ecosystems \& Environment 149:1-9.

Milligan, M. C., M. D. Johnson, M. Garfinkel, C. J. Smith, and P. Njoroge. 2016. Quantifying pest control services by birds and ants in Kenyan coffee farms. Biological Conservation 194:58-65.

Mols, C. M. M. and M. E. Visser. 2002. Great tits can reduce caterpillar damage in apple orchards. Journal of Applied Ecology 39:888-899.

Mols, C. M. M. and M. E. Visser. 2007. Great Tits (Parus major) Reduce Caterpillar Damage in Commercial Apple Orchards. Plos One 2.

Mooney, K. A., D. S. Gruner, N. A. Barber, S. A. Van Bael, S. M. Philpott, and R. Greenberg. 2010. Interactions among predators and the cascading effects of vertebrate insectivores on arthropod communities and plants. Proceedings of the National Academy of Sciences of the United States of America 107:7335-7340.

Mulwa, R. K., K. Bohning-Gaese, and M. Schleuning. 2012. High Bird Species Diversity in Structurally Heterogeneous Farmland in Western Kenya. Biotropica 44:801-809.

Munoz, J. C., R. Aerts, K. W. Thijs, P. R. Stevenson, B. Muys, and C. H. Sekercioglu. 2013. Contribution of woody habitat islands to the conservation of birds and their potential ecosystem services in an extensive Colombian rangeland. Agriculture Ecosystems \& Environment 173:13-19.

Myczko, L., Z. M. Rosin, P. Skorka, P. Wylegala, M. Tobolka, M. Fliszkiewicz, T. Mizera, and P. Tryjanowski. 2013. Effects of management intensity and orchard features on bird communities in winter. Ecological Research 28:503-512.

Ndang'ang'a, P. K., J. B. M. Njoroge, K. Ngamau, W. Kariuki, P. W. Atkinson, and J. Vickery. 2013a. Avian foraging behaviour in relation to provision of ecosystem services in a highland East African agroecosystem. Bird Study 60:156-168. 
Ndang'ang'a, P. K., J. B. M. Njoroge, and J. Vickery. 2013b. Quantifying the contribution of birds to the control of arthropod pests on kale, Brassica oleracea acephala, a key crop in East African highland farmland. International Journal of Pest Management 59:211-216.

Newbold, T., J. P. W. Scharlemann, S. H. M. Butchart, C. H. Sekercioglu, L. Joppa, R. Alkemade, and D. W. Purves. 2014. Functional traits, land-use change and the structure of present and future bird communities in tropical forests. Global Ecology and Biogeography 23:1073-1084.

Orlowski, G., J. Karg, and G. Karg. 2014. Functional Invertebrate Prey Groups Reflect Dietary Responses to Phenology and Farming Activity and Pest Control Services in Three Sympatric Species of Aerially Foraging Insectivorous Birds. Plos One 9.

Peisley, R. K., M. E. Saunders, and G. W. Luck. 2015. A sistematic review of the benefits and costs of bird and insect activity in agroecosystems. Springer science reviews 3:113-125.

Perfecto, I., I. Armbrecht, S. M. Philpott, L. Soto-Pinto, and T. V. Dietsch. 2007. Shaded coffee and the stability of rainforest margins in northern Latin America. Stability of Tropical Rainforest Margins: Linking Ecological, Economic and Social Constraints of Land Use and Conservation:227-263.

Perfecto, I., J. H. Vandermeer, G. L. Bautista, G. I. Nunez, R. Greenberg, P. Bichier, and S. Langridge. 2004. Greater predation in shaded coffee farms: The role of resident neotropical birds. Ecology 85:2677-2681.

Pesley, R. K., M. E. Saunders, and G. W. Luck. 2016. Cost-benefit trade-offs of bird activity in apple orchards. Peerj:1-20.

Peters, V. E. and R. Greenberg. 2013. Fruit Supplementation Affects Birds but not Arthropod Predation by Birds in Costa Rican Agroforestry Systems. Biotropica 45:102-110.

Philpott, S. M., W. J. Arendt, I. Armbrecht, P. Bichier, T. V. Diestch, C. Gordon, R. Greenberg, I. Perfecto, R. Reynoso-Santos, L. Soto-Pinto, C. Tejeda-Cruz, G. Williams-Linera, J. Valenzuela, and J. M. Zolotoff. 2008. Biodiversity Loss in Latin American Coffee Landscapes: Review of the Evidence on Ants, Birds, and Trees. Conservation Biology 22:1093-1105.

Philpott, S. M. and P. Bichier. 2012. Effects of shade tree removal on birds in coffee agroecosystems in Chiapas, Mexico. Agriculture Ecosystems \& Environment 149:171-180.

Philpott, S. M., R. Greenberg, P. Bichier, and I. Perfecto. 2004. Impacts of major predators on tropical agroforest arthropods: comparisons within and across taxa. Oecologia 140:140-149. 
Philpott, S. M., O. Soong, J. H. Lowenstein, A. L. Pulido, D. T. Lopez, D. F. B. Flynn, and F. DeClerck. 2009. Functional richness and ecosystem services: bird predation on arthropods in tropical agroecosystems. Ecological Applications 19:1858-1867.

Pimentel, D., C. Wilson, C. McCullum, R. Huang, P. Dwen, J. Flack, Q. Tran, T. Saltman, and B. Cliff. 1997. Economic and environmental benefits of biodiversity. Bioscience 47:747-757.

Pinol, J., X. Espadaler, N. Canellas, J. Martinez-Vilalta, J. A. Barrientos, and D. Sol. 2010. Ant versus bird exclusion effects on the arthropod assemblage of an organic citrus grove. Ecological Entomology 35:367-376.

Poch, T. J. and J. A. Simonetti. 2013. Ecosystem services in human-dominated landscapes: insectivory in agroforestry systems. Agroforestry Systems 87:871-879.

Power, A. G. 2010. Ecosystem services and agriculture: tradeoffs and synergies. Philosophical Transactions of the Royal Society B-Biological Sciences 365:2959-2971.

Prabowo, W. E., K. Darras, Y. Clough, M. Toledo-Hernandez, R. Arlettaz, Y. A. Mulyani, and T. Tscharntke. 2016. Bird Responses to Lowland Rainforest Conversion in Sumatran Smallholder Landscapes, Indonesia. Plos One 11.

Puckett, H. L., J. R. Brandle, R. J. Johnson, and E. E. Blankenship. 2009. Avian foraging patterns in crop field edges adjacent to woody habitat. Agriculture Ecosystems \& Environment 131:9-15.

Pumarino, L., G. W. Sileshi, S. Gripenberg, R. Kaartinen, E. Barrios, M. N. Muchane, C. Midega, and M. Jonsson. 2015. Effects of agroforestry on pest, disease and weed control: A meta-analysis. Basic and Applied Ecology 16:573-582.

Railsback, S. F. and M. D. Johnson. 2011. Pattern-oriented modeling of bird foraging and pest control in coffee farms. Ecological Modelling 222:33053319.

Railsback, S. F. and M. D. Johnson. 2014. Effects of land use on bird populations and pest control services on coffee farms. Proceedings of the National Academy of Sciences of the United States of America 111:6109-6114.

Rusch, A., K. Birkhofer, R. Bommarco, H. G. Smith, and B. Ekbom. 2014. Management intensity at field and landscape levels affects the structure of generalist predator communities. Oecologia 175:971-983. 
Rusch, A., R. Chaplin-Kramer, M. M. Gardiner, V. Hawro, J. Holland, D. Landis, C. Thies, T. Tscharntke, W. W. Weisser, C. Winqvist, M. Woltz, and R. Bommarco. 2016. Agricultural landscape simplication reduces natural pest control: a quantitative analysis. Agriculture, Ecosystems, and Environment 221:198-204.

Sagoff, M. 2011. The quantification and valuation of ecosystem services. Ecological Economics 70:497-502.

Sanchez-Zapata, J. A., J. A. Donazar, A. Delgado, M. G. Forero, O. Ceballos, and F. Hiraldo. 2007. Desert locust outbreaks in the Sahel: resource competition, predation and ecological effects of pest control. Journal of Applied Ecology 44:323-329.

Sarwar, M., I. Hussain, M. Anwar, and S. N. Mirza. 2016. BASELINE DATA ON ANTHROPOGENIC PRACTICES IN THE AGRO-ECOSYSTEM OF POTHWAR PLATEAU, PAKISTAN. Journal of Animal and Plant Sciences 26:850-857.

Saunders, M. E. and G. W. Luck. 2016. Combining Costs and Benefits of Animal Activities to Assess Net Yield Outcomes in Apple Orchards. Plos One 11.

Schackermann, J., G. Pufal, Y. Mandelik, and A. M. Klein. 2015. Agro-ecosystem services and dis-services in almond orchards are differentially influenced by the surrounding landscape. Ecological Entomology 40:12-21.

Sekercioglu, C. H. 2006. Increasing awareness of avian ecological function. Trends in Ecology \& Evolution 21:464-471.

Sekercioglu, C. H. 2012. Bird functional diversity and ecosystem services in tropical forests, agroforests and agricultural areas. Journal of Ornithology 153:S153-S161.

Sekercioglu, C. H., G. C. Daily, and P. R. Ehrlich. 2004. Ecosystem consequences of bird declines. Proceedings of the National Academy of Sciences of the United States of America 101:18042-18047.

Sinu, P. A. 2011. Avian pest control in tea plantations of sub-Himalayan plains of Northeast India: Mixed-species foraging flock matters. Biological Control 58:362-366.

Solomon, M. E. and D. M. Glen. 1979. Prey Density and Rates of Predation by Tits (Parus Spp) on Larvae of Codling Moth (Cydia-Pomonella) under Bark. Journal of Applied Ecology 16:49-59.

Solomon, M. E., D. M. Glen, D. A. Kendall, and N. F. Milsom. 1976. Predation of Overwintering Larvae of Codling Moth (Cydia-Pomonella -L) by Birds. Journal of Applied Ecology 13:341-\&. 
Tamburini, G., S. De Simone, M. Sigura, F. Boscutti, and L. Marini. 2016. Conservation tillage mitigates the negative effect of landscape simplification on biological control. Journal of Applied Ecology 53:233-241.

Thompson, I. D., K. Okabe, J. A. Parrotta, E. Brockerhoff, H. Jactel, D. I. Forrester, and H. Taki. 2014. Biodiversity and ecosystem services: lessons from nature to improve management of planted forests for REDD-plus. Biodiversity and Conservation 23:2613-2635.

Thuiller, W., S. Pironon, A. Psomas, M. Barbet-Massin, F. Jiguet, S. Lavergne, P. B. Pearman, J. Renaud, L. Zupan, and N. E. Zimmermann. 2014. The European functional tree of bird life in the face of global change. Nature Communications 5.

Tremblay, A., P. Mineau, and R. K. Stewart. 2001. Effects of bird predation on some pest insect populations in corn. Agriculture Ecosystems \& Environment 83:143-152.

Triplett, S., G. W. Luck, and P. G. Spooner. 2012. The importance of managing the costs and benefits of bird activity for agricultural sustainability. International Journal of Agricultural Sustainability 10:268-288.

Tscharntke, T., Y. Clough, S. A. Bhagwat, D. Buchori, H. Faust, D. Hertel, D. Holscher, J. Juhrbandt, M. Kessler, I. Perfecto, C. Scherber, G. Schroth, E. Veldkamp, and T. C. Wanger. 2011. Multifunctional shade-tree management in tropical agroforestry landscapes - a review. Journal of Applied Ecology 48:619-629.

Tscharntke, T., A. M. Klein, A. Kruess, I. Steffan-Dewenter, and C. Thies. 2005. Landscape perspectives on agricultural intensification and biodiversity ecosystem service management. Ecology Letters 8:857-874.

Tscharntke, T., C. H. Sekercioglu, T. V. Dietsch, N. S. Sodhi, P. Hoehn, and J. M. Tylianakis. 2008. Landscape constraints on functional diversity of birds and insects in a tropical agroecosystem (vol 89, pg 944, 2008). Ecology 89.

Tschumi, M., M. Albrecht, M. H. Entling, and K. Jacot. 2015. High effectiveness of tailored flower strips in reducing pests and crop plant damage. Proceedings of the Royal Society B-Biological Sciences 282:189-196.

Van Bael, S. A., S. M. Philpott, R. Greenberg, P. Bichier, N. A. Barber, K. A. Mooney, and D. S. Gruner. 2008. Birds as predators in tropical agroforestry systems. Ecology 89:928-934. 
Vickery, J. A., R. E. Feber, and R. J. Fuller. 2009. Arable field margins managed for biodiversity conservation: A review of food resource provision for farmland birds. Agriculture Ecosystems \& Environment 133:1-13.

Wearing, C. H. and K. Mccarthy. 1992. Predation of Codling Moth Cydia-Pomonella L by the Silvereye Zosterops-Lateralis (Latham). Biocontrol Science and Technology 2:285-295.

Wenny, D. G., T. L. DeVault, M. D. Johnson, D. Kelly, C. H. Sekercioglu, D. F. Tomback, and C. J. Whelan. 2011. The Need to Quantify Ecosystem Services Provided by Birds. Auk 128:1-14.

Werling, B. P., T. L. Dickson, R. Isaacs, H. Gaines, C. Gratton, K. L. Gross, H. Liere, C. M. Malmstrom, T. D. Meehan, L. L. Ruan, B. A. Robertson, G. P. Robertson, T. M. Schmidt, A. C. Schrotenboer, T. K. Teal, J. K. Wilson, and D. A. Landis. 2014. Perennial grasslands enhance biodiversity and multiple ecosystem services in bioenergy landscapes. Proceedings of the National Academy of Sciences of the United States of America 111:1652-1657.

Whelan, C. J., D. G. Wenny, and R. J. Marquis. 2008. Ecosystem services provided by birds. Year in Ecology and Conservation Biology 2008 1134:25-60.

Wilsey, C. B. and S. A. Temple. 2011. The Effects of Cropping Systems on Avian Communities in Cacao and Banana Agro-Forestry Systems of Talamanca, Costa Rica. Biotropica 43:68-76.

Winqvist, C., J. Bengtsson, T. Aavik, F. Berendse, L. W. Clement, S. Eggers, C. Fischer, A. Flohre, F. Geiger, J. Liira, T. Paert, C. Thies, T. Tscharntke, W. W. Weisser, and R. Bommarco. 2011. Mixed effects of organic farming and landscape complexity on farmland biodiversity and biological control potential across Europe. Journal of Applied Ecology 48:570-579.

Zhang, W., T. H. Ricketts, C. Kremen, K. Carney, and S. M. Swinton. 2007. Ecosystem services and dis-services to agriculture. Ecological Economics 64:253-260. 
Table S2: Bird species providing pest control services in agricultural crops identified in literature review. The bird names follow the 2015 IOC Bird world list (Gill and Donsker 2015, available at: http://www.worldbirdnames.org/ioc-lists/). Numbers 1-14: enumerated literature from empirical studies in tropical biomes; 15-25: enumerated literature from empirical studies in temperate biome. Literature correspondent to each study is described below. Diet. RI: restrictive insectivores (exclusive insect feeders); GI: generalist insectivores (insect feeders that complement their diet with fruits or seeds); OI: occasional insectivores (species that feed predominantly on noninsect resources but occasionally ingest insects); NI: non-insectivores; OM: omnivores. Habitat. HD: native habitat-dependent; HG: habitat-generalist species.

\begin{tabular}{|c|c|c|c|c|c|c|c|c|c|c|c|c|c|c|c|c|c|c|c|c|c|c|c|c|c|c|c|c|}
\hline Scientific name & Family & 1 & 2 & 3 & 4 & 5 & 6 & 7 & 8 & 9 & 10 & 11 & 12 & 13 & 14 & 15 & 16 & 17 & 18 & 19 & 20 & 21 & 22 & 23 & 24 & 25 & Diet & Habitat \\
\hline Corvus brachyrhynchos & Corvidae & & & & & & & & & & & & & & & & & & & & $\mathrm{X}$ & & & & & $\mathrm{X}$ & $\mathrm{OM}$ & $\mathrm{HG}$ \\
\hline Carduelis tristis & Fringillidae & & & & & & & & & & & & & & & & & & & & & & $\mathrm{X}$ & & & & OI & $\mathrm{HG}$ \\
\hline Setophaga ruticilla & Parulidae & & & & & & & & & & & & $\mathrm{X}$ & & & & & & & & $\mathrm{X}$ & & & & & & RI & HD \\
\hline Turdus migratorius & Turdidae & & & & & & & & & & & & & & $\mathrm{X}$ & & & & & & & & $\mathrm{X}$ & & & $\mathrm{X}$ & GI & $\mathrm{HG}$ \\
\hline Dendroica castanea & Parulidae & & & & & & & & & & & & & & & & & & & & $\mathrm{X}$ & & & & & & GI & HD \\
\hline Mniotilta varia & Parulidae & & & & & $\mathrm{X}$ & & & & & & & $\mathrm{X}$ & & & & & & & & $\mathrm{X}$ & & & & & & RI & HD \\
\hline Dendroica striata & Parulidae & & & & & & & & & & & & & & & & & & & & $\mathrm{X}$ & & & & & & $\mathrm{OM}$ & HD \\
\hline Passerina caerulea & Cardinalidae & & & & & & & & & & & & & & & & & & & & $\mathrm{X}$ & & & & & & GI & $\mathrm{HG}$ \\
\hline Cyanocitta cristata & Corvidae & & & & & & & & & & & & & & & & & & & & $\mathrm{X}$ & & $\mathrm{X}$ & & & & $\mathrm{OM}$ & $\mathrm{HG}$ \\
\hline Polioptila caerulea & Polioptilidae & & & & & & & & & & & & & & & & & & & & $\mathrm{X}$ & & & & & & RI & HG \\
\hline Quiscalus major & Icteridae & & & & & & & & & & & & & & & & & & & & $\mathrm{X}$ & & & & & & $\mathrm{OM}$ & $\mathrm{HG}$ \\
\hline Dolichonyx oryzivorus & Icteridae & & & & & & & & & & & & & & & & & & & & $\mathrm{X}$ & & & & & & OI & $\mathrm{HG}$ \\
\hline Taxostoma rufum & Mimidae & & & & & & & & & & & & & & & & & & & & $\mathrm{X}$ & & $\mathrm{X}$ & & & & $\mathrm{OM}$ & $\mathrm{HG}$ \\
\hline Poecile carolinensis & Paridae & & & & & & & & & & & & & & & & & & & & $\mathrm{X}$ & & & & & & GI & HD \\
\hline $\begin{array}{l}\text { Thryothorus } \\
\text { ludovicianus }\end{array}$ & Troglodytidae & & & & & & & & & & & & & & & & & & & & $\mathrm{X}$ & & & & & & GI & HG \\
\hline Bulbucus ibis & Ardeidae & & & & & & & & & & & & & & & & & & & & $\mathrm{X}$ & & & & & & GI & $\mathrm{HG}$ \\
\hline Quiscalus quiscula & Icteridae & & & & & & & & & & & & & & & & & & & & & & $\mathrm{X}$ & & & & $\mathrm{OM}$ & $\mathrm{HG}$ \\
\hline Columbina passerina & Columbidae & & & & & & & & & & & & & & & & & & & & $\mathrm{X}$ & & & & & & $\mathrm{NI}$ & $\mathrm{HG}$ \\
\hline Geothlypis trichas & Parulidae & & & & & & & & & & & & $\mathrm{X}$ & & & & & & & & $\mathrm{X}$ & & & & & & RI & $\mathrm{HD}$ \\
\hline
\end{tabular}




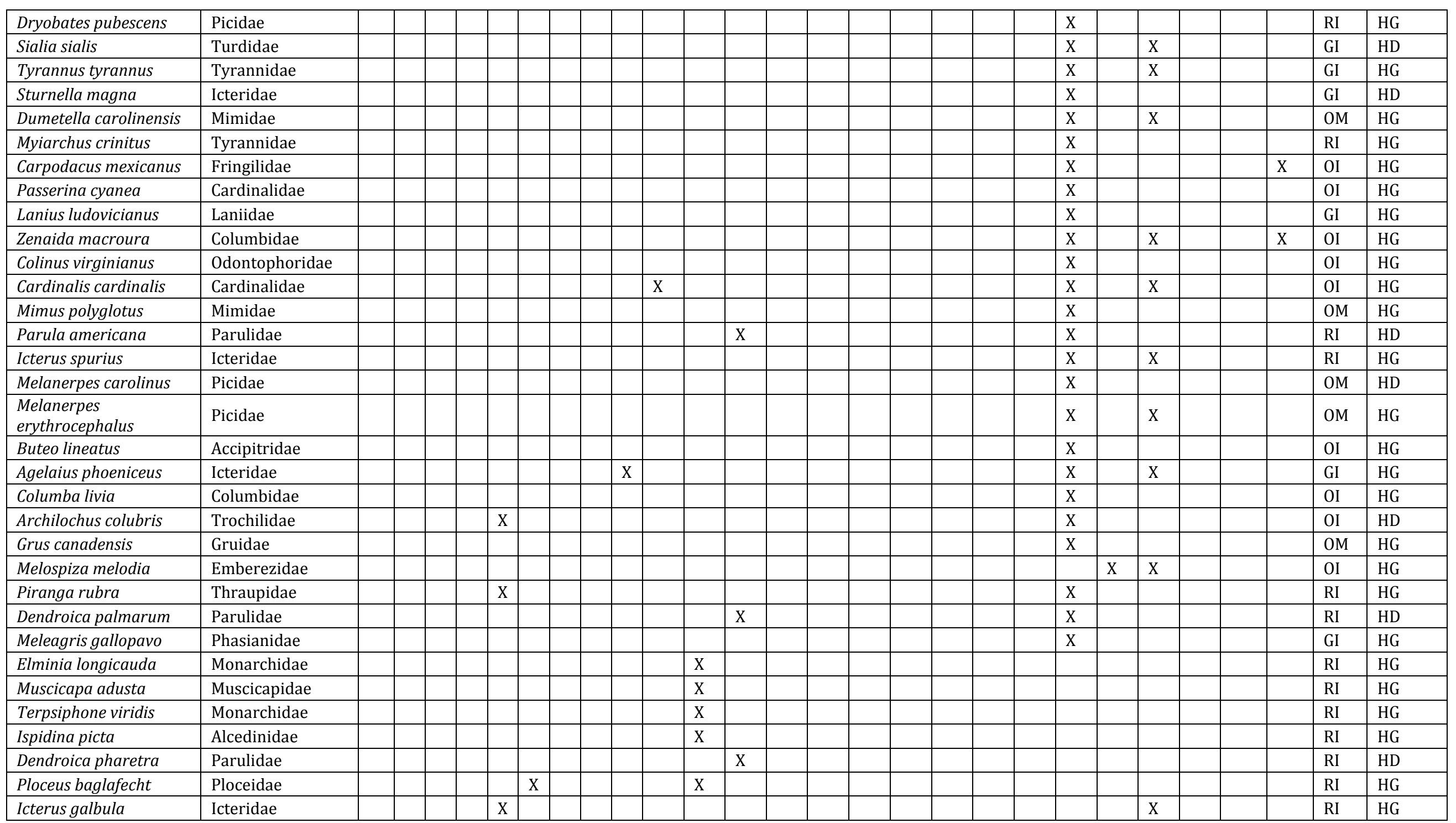




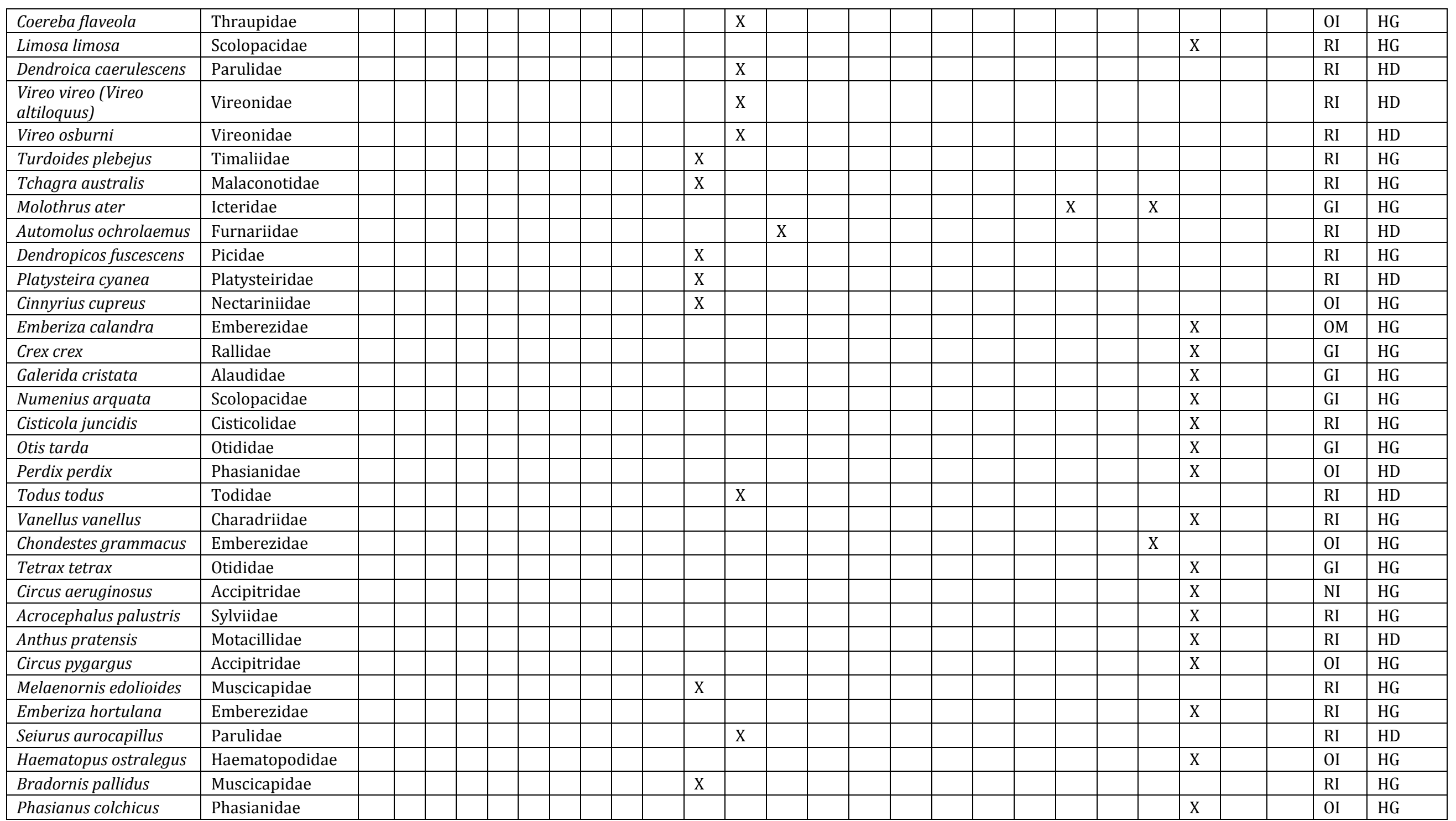




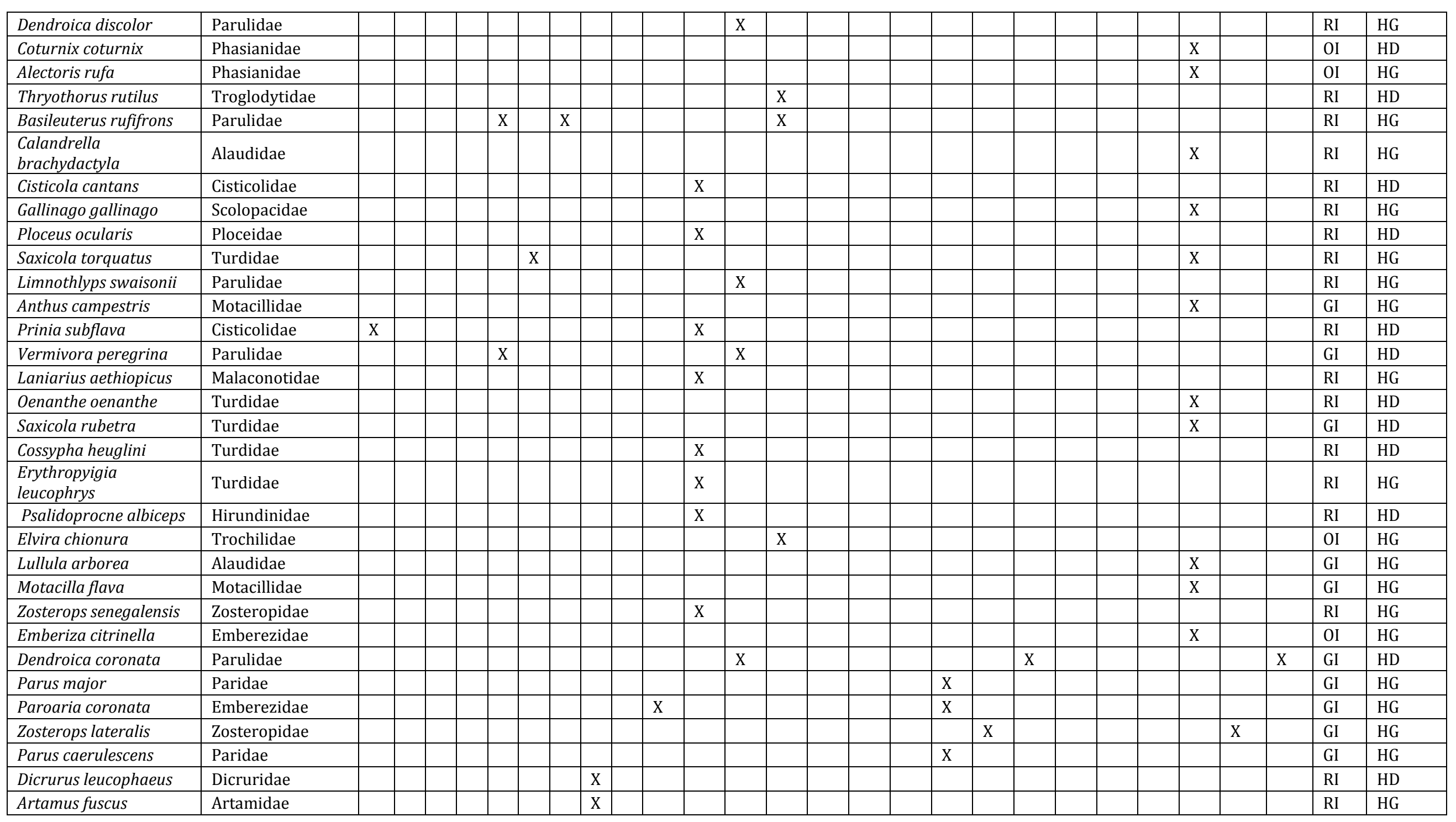




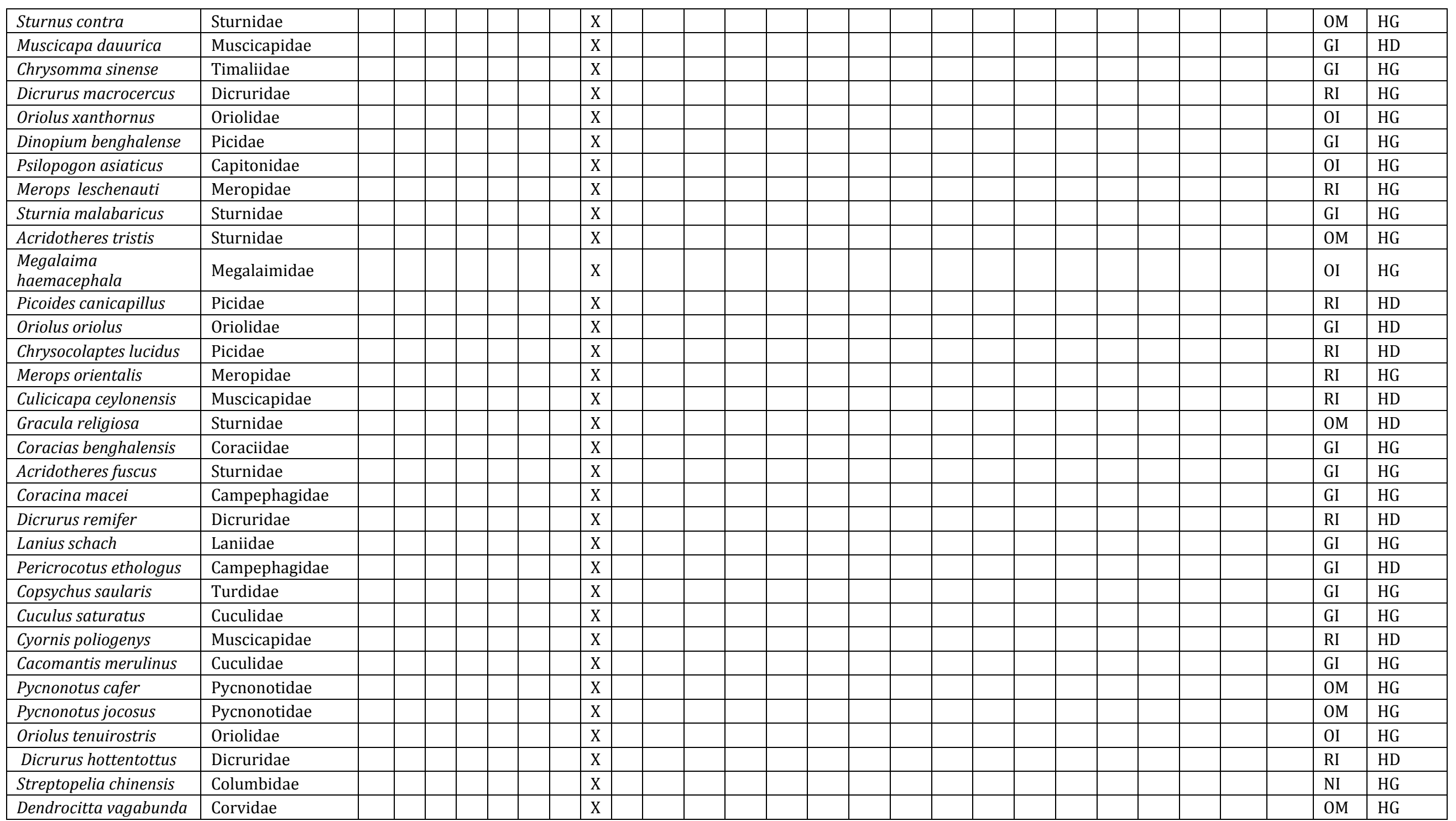




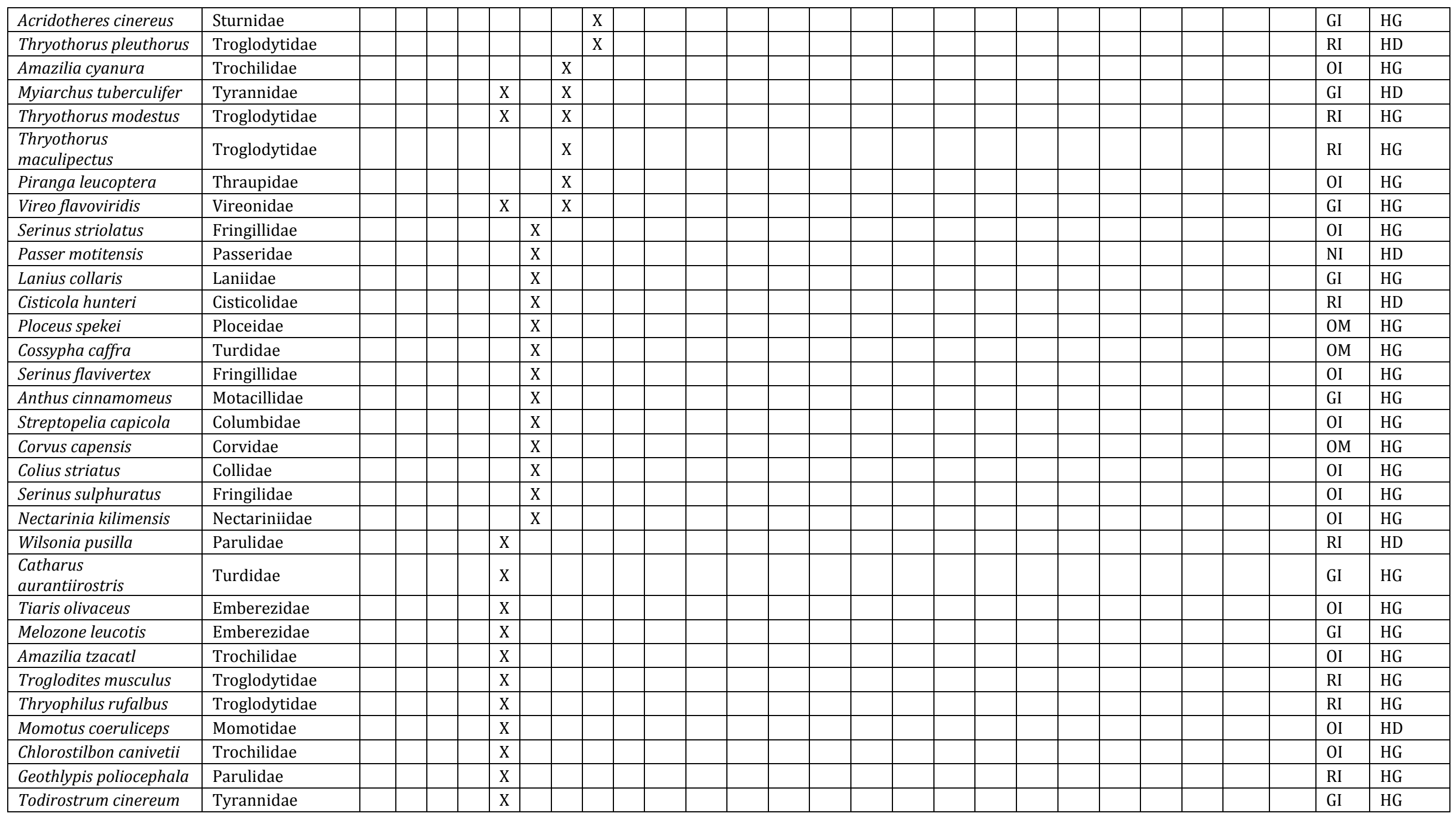




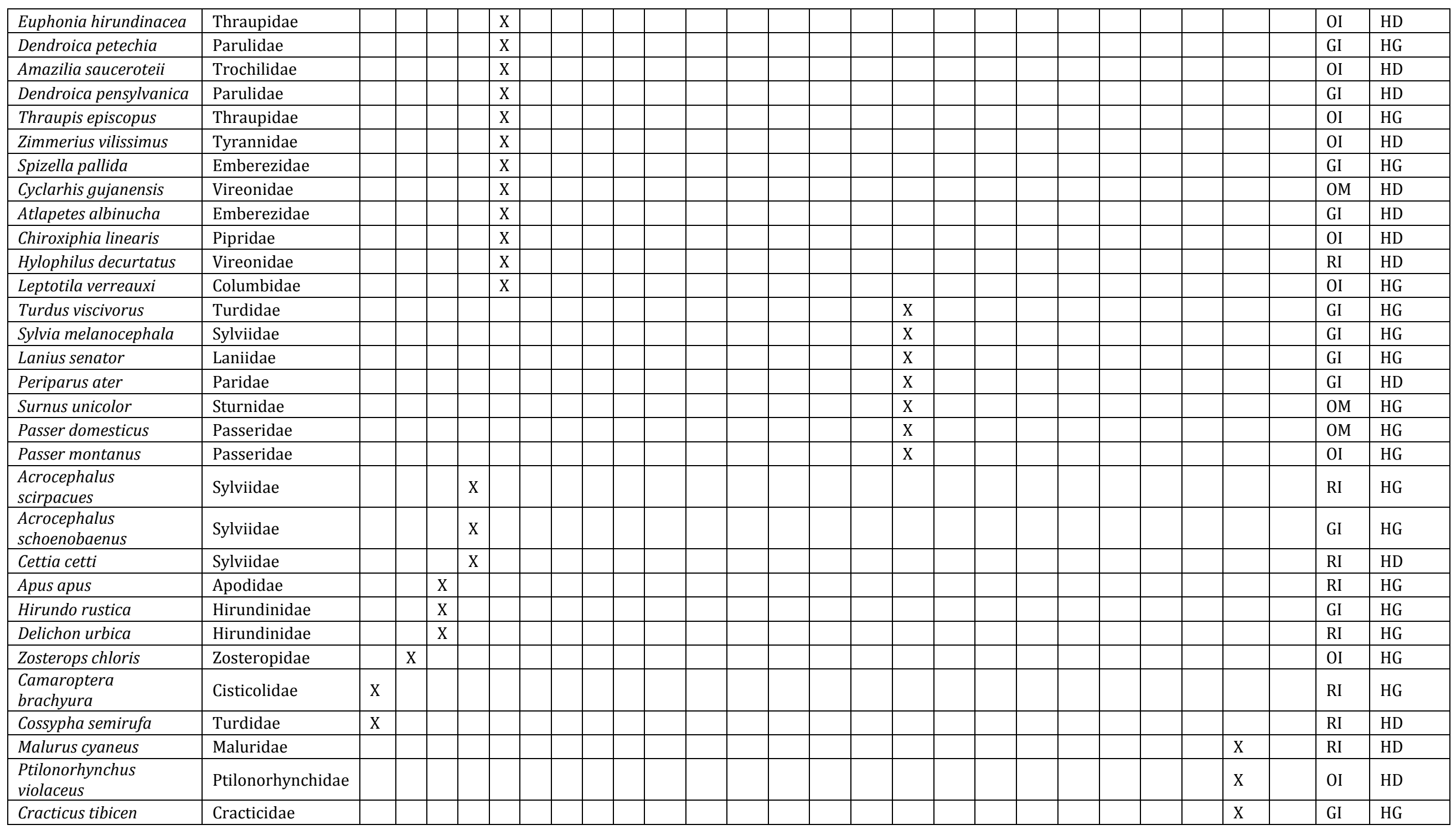




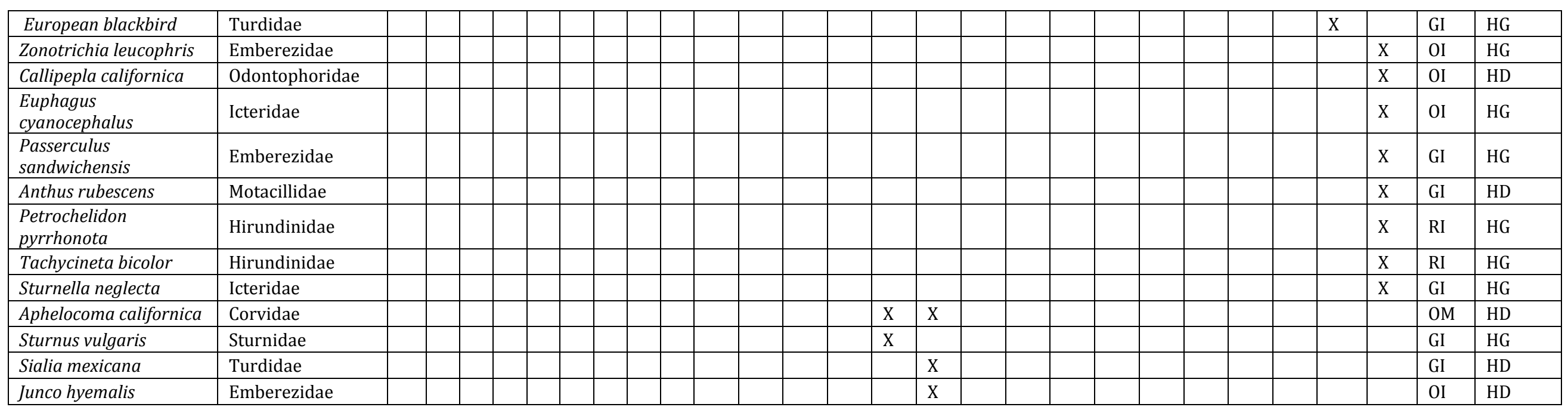

\section{Literature cited}

(1) Lemessa D. Hamback PA, Hylander K (2015) Arthropod but Not Bird Predation in Ethiopian Homegardens Is Higher in Tree-Poor than in Tree-Rich Landscapes. Plos One 10(5)

(2) Maas B, Tscharntke T, Saleh S, Putra DD, Clough Y (2015) Avian species identity drives predation success in tropical cacao agroforestry. J Appl Ecol 52(3):735-743

(3) Orlowski G, Karg J, Karg G (2014) Functional Invertebrate Prey Groups Reflect Dietary Responses to Phenology and Farming Activity and Pest Control Services in Three Sympatric Species of Aerially Foraging Insectivorous Birds. Plos One 9(12)

(4) King RA, Symondson WOC, Thomas RJ (2015) Molecular analysis of faecal samples from birds to identify potential crop pests and useful biocontrol agents in natural areas. Bulletin of Entomological Research 105(3):261-272 
(5) Peters VE, Greenberg R (2013) Fruit Supplementation Affects Birds but not Arthropod Predation by Birds in Costa Rican Agroforestry Systems. Biotropica 45(1):102-110

(6) Ndang'ang'a PK, Njoroge JBM, Ngamau K, Kariuki W, Atkinson PW, Vickery J (2013) Avian foraging behaviour in relation to provision of ecosystem services in a highland East African agroecosystem. Bird Study 60(2):156-168

(7) Perfecto I, Vandermeer JH, Bautista GL et al (2004) Greater predation in shaded coffee farms: The role of resident neotropical birds. Ecology 85(10):2677-2681

(8) Sinu PA (2011) Avian pest control in tea plantations of sub-Himalayan plains of Northeast India: Mixed-species foraging flock matters. Biol Control 58(3):362-366

(9) Borkhataria RR, Nuessly GS, Pearlstine E, Cherry RH (2012) Effects of Blackbirds (Agelaius Phoenicius) on Stink Bug (Hemiptera: Pentatomidae) Populations, Damage, and Yield in Florida Rice. Fla Entomol 95(1):143-149

(10) Hooks CRR, Pandey RR, Johnson MW (2003) Impact of avian and arthropod predation on lepidopteran caterpillar densities and plant productivity in an ephemeral agroecosystem. Ecol Entomol 28(5):522-532

(11) Ferger SW, Boehning-Gaese K, Wilcke W, Oelmann Y, Schleuning M (2013) Distinct carbon sources indicate strong differentiation between tropical forest and farmland bird communities. Oecologia 171(2):473-486

(12) Kellermann JL, Johnson MD, Stercho AM, Hackett SC (2008) Ecological and Economic Services Provided by Birds on Jamaican Blue Mountain Coffee Farms. Conserv Biol 22(5):1177-1185

(13) Karp DS, Mendenhall CD, Sandi RF et al (2013) Forest bolsters bird abundance, pest control and coffee yield. Ecol Lett 16(11):1339-1347

(14) Garfinkel M. \& Johnson M. (2015). Pest-removal services provided by birds on small organic farms in northern California. Agr Ecosyst Environ, 211, 24-31

(15) Howard, K. A. \& Johnson, M. D. (2014). Effects of natural habitat on pest control in california vineyards. Western Birds 45: 276-283

(16) Pinol J, Espadaler X, Canellas N, Martinez-Vilalta J, Barrientos JA, Sol D (2010) Ant versus bird exclusion effects on the arthropod assemblage of an organic citrus grove. Ecol Entomol 35(3):367-376 
(17) Solomon ME, Glen DM, Kendall DA, Milsom NF (1976) Predation of Overwintering Larvae of Codling Moth (Cydia-Pomonella -L) by Birds. J Appl Ecol 13(2):341-\&

(18) Wearing CH, Mccarthy K (1992) Predation of Codling Moth Cydia-Pomonella L by the Silvereye Zosterops-Lateralis (Latham). Biocontrol Sci Techn 2(4):285-295

(19) Mols CMM, Visser ME (2002) Great tits can reduce caterpillar damage in apple orchards. J Appl Ecol 39(6):888-899

(19) Mols CMM, Visser ME (2007) Great Tits (Parus major) Reduce Caterpillar Damage in Commercial Apple Orchards. Plos One 2(2)

(20) Jones GA, Sieving KE, Jacobson SK (2005) Avian diversity and functional insectivory on north-central Florida farmlands. Conserv Biol 19(4):1234-1245

(21) Girard J, Baril A, Mineau P, Fahrig L (2012) Foraging habitat and diet of Song Sparrows (Melospiza melodia) nesting in farmland: a stable isotope approach. Can J Zool 90(11):1339-1350

(22) Puckett HL, Brandle JR, Johnson RJ, Blankenship EE (2009) Avian foraging patterns in crop field edges adjacent to woody habitat. Agr Ecosyst Environ 131(1-2):9-15

(23) Geiger F, Bengtsson J, Berendse F et al (2010) Persistent negative effects of pesticides on biodiversity and biological control potential on European farmland. Basic Appl Ecol 11(2):97-105

(24) Pesley R.K., Saunders M.E. \& Luck G.W. (2016). Cost-benefit trade-offs of bird activity in apple orchards. Peer], 1-20.

(25)Kross S.M., Kelsey T.R., McColl C.J. \& Townsend J.M. (2016). Field-scale habitat complexity enhances avian conservation and avian-mediated pest-control services in an intensive agricultural crop. Agr Ecosyst Environ, 225, 140-149. 


\section{Chapter 2}

Taxonomic, functional, and phylogenetic thresholds are modulated by matrix composition

Andrea Larissa Boesing, Elizabeth Nichols, Jean Paul Metzger

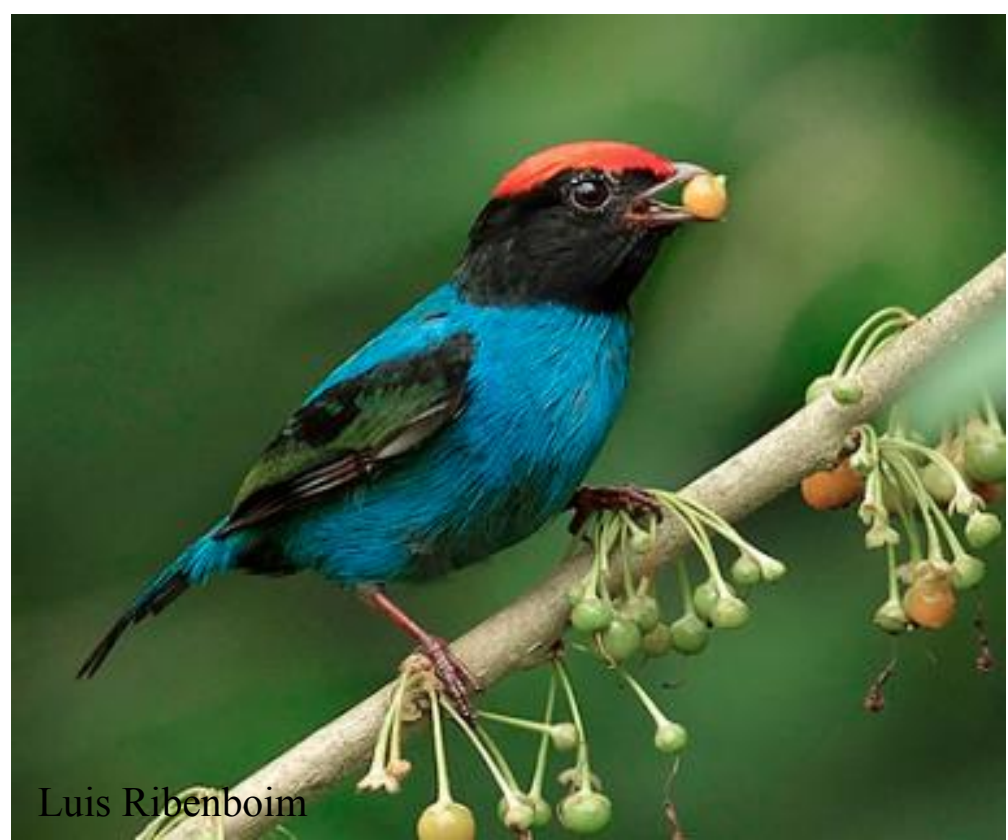




\section{Abstract}

The biodiversity extinction threshold is an abrupt decline in species richness with habitat loss. It arises as declining landscape connectivity reduces dispersal and increases local species extinction across remaining native habitat patches. Matrix composition should influence threshold dynamics through its effects on landscape connectivity. Using 23 1,254 ha independent landscapes in the Brazilian Atlantic Rainforest, we evaluated how tropical avian biodiversity respond to native forest loss in agricultural matrices with different permeability contexts: lowerpermeability (cattle pastures, $n=13$ ) and higher-permeability (coffee plantations, $\mathrm{n}=10$ ). We defined biodiversity in three ways, as taxonomic (TD), functional (FD), and phylogenetic diversity (PD). We tested two hypotheses: i) that lowerpermeability matrix is associated with more abrupt species loss than higherpermeability matrix, and ii) that thresholds using TD, FD, and PD occur in distinct amounts of remaining native habitat. We found that both matrix composition and choice of diversity metric strongly influenced the location of this threshold along the forest cover gradient. First, coffee matrices are able to maintain higher TD in lower amounts of remaining forest cover compared to pasture matrices. The extinction threshold for TD occurred at 35\% remaining habitat in pasture matrices, and $19 \%$ remaining habitat in coffee matrices. Second, PD was lost almost at same time as TD (at 28\% and 22\% in pasture and coffee matrices respectively) and a strong phylogenetic clustering was found in coffee matrices, indicating environmental filter driving phylogenetic structure of assemblages. Finally, we found no clear predictor for FD - although there is a substantial reduction in FD below 20\% remaining habitat in both matrices. These results highlight the importance of investigating different biodiversity indices when evaluating impacts of land use change on ecosystems, as well as the importance of matrix permeability in facilitating species movement among patches, maintaining higher biodiversity levels, and providing avian-mediated ecosystem services.

Key-words: Atlantic rainforest, Coffee plantations, Functional diversity, Habitat loss, Landscape structure, Pasture lands, Phylogenetic diversity. 


\section{Introduction}

Anthropogenic habitat loss, particularly in tropical forests, is considered the principal driver of the ongoing biodiversity crisis (MEA 2005). Through a suite of deleterious effects on individual fitness (Foley et al. 2005), habitat loss causes well-described changes in species richness and community structure (Pardini et al. 2010). These losses in taxonomic diversity are accompanied by important changes in functional diversity that may significantly impact ecosystem function (Bregman et al. 2014, Oliver et al. 2015), and by losses of phylogenetic diversity that may curtail future resilience in both biodiversity and function (Frishkoff et al. 2014). From a practical standpoint, there is a strong interest in understanding how much native habitat is needed to maintain certain biodiversity standards and ecosystem functionality (Fahrig 2002, Ficetola and Denoel 2009).

While the relationship between taxonomic diversity and remaining native habitat cover varies across taxa and regions, it is typically non-linear and characterized by sharp thresholds of loss between $20-40 \%$ remaining habitat, with some variability depending on the region and taxonomic group: e.g. 30\% for small tropical mammals (Estavillo et al. 2013), 30-40\% for large tropical mammals (Ochoa-Quintero et al. 2015), 18-33\% for forest birds (Betts et al. 2007, BanksLeite et al. 2014, Richmond et al. 2015), and 30-40\% for vascular plants (Goncalves Rigueira et al. 2013, Lima and Mariano-Neto 2014). Extinction threshold theory holds that biodiversity thresholds are largely governed by the degree of dispersal among native habitat fragments, and therefore influenced by landscape structural components such as the number and size of remaining patches and their isolation (Andren 1994).

These biodiversity thresholds are theoretically influenced by the composition of the non-native habitat matrix surrounding native habitat patches, which influences community composition and ecological processes, both by modulating organismal movement and dispersal and by influencing abiotic environment of native patches (Driscoll et al. 2013, Prevedello et al. In press). Matrix types range from structurally simple land-uses dominated by agriculture monocultures to complex and heterogeneous land-uses composed of different crop or vegetation types, which are more similar to native habitat patches (Tscharntke 
et al. 2007). The type of matrix strongly influences organism movement and dispersal between native habitat patches (Driscoll et al. 2013). Theoretically, a more permeable matrix should facilitate native species movement through the landscape and thus should maintain species in habitat patches at lower levels of landscape-scale native habitat cover than would otherwise be possible, retarding species extinctions and postponing extinction thresholds along the process of landscape degradation (Fig. 1A). Explicit consideration of the matrix has remained surprisingly absent from the extinction threshold literature, and the majority of studies do not include matrix composition (Estavillo et al. 2013, Banks-Leite et al. 2014, Ochoa-Quintero et al. 2015) in spite of the fact that it strongly influences processes related to species persistence in fragmented landscapes (e.g.Bender and Fahrig 2005, Ewers and Didham 2006, Kupfer et al. 2006).

In addition, existing biodiversity threshold studies have overwhelming explored the effects of declining habitat on one measure of biological diversity taxonomic diversity, defined either as species richness (Estavillo et al. 2013) or as community integrity (Banks-Leite et al. 2014). However, taxonomic diversity may not be the most effective measurement of diversity, particularly in terms of efforts to understanding the relationships between diversity and potential ecosystem functioning (Diaz and Cabido 2001, Fahrig 2013). Measures of functional and phylogenetic diversity also contain valuable information regarding ecosystem functioning (Petchey and Gaston 2006) and community evolutionary history (Ricotta 2005), and may thus be important complements to taxonomic diversity in efforts to identify the consequences of environmental change (Jarzyna and Jetz 2016). Functional diversity reflects the variety of functional traits within a community (Jarzyna and Jetz 2016) composing a major component of ecosystem functioning (Hooper et al. 2005), and it can be measured using different approaches (e.g. Tilman 2001, Petchey and Gaston 2002, Mason et al. 2003, Cornwell et al. 2006). Phylogenetic diversity is based on cladistics relationships (Faith 1992) and reflects the evolutionary history of a species assemblage (Webb 2000, Villeger et al. 2008) and many metrics can be used to capture it as well (Tucker et al. 2016). A common measure is the sum of the branches lengths in a dendogram (Faith 1992) representing differences among species in terms of forms or functions (Mouchet et al. 2008). 
Extinction thresholds for taxonomic, functional, and phylogenetic diversity are likely to occur in different amounts of remaining native habitat (Fig. 1B). Taxonomic diversity should be the most sensitive index to habitat loss, as it is influenced by the loss of each individual species (Owens and Bennett 2000, Brooks et al. 2002). Functional diversity is likely to be slightly less sensitive than taxonomic diversity due to species replacement, as species may be lost without losing community-level representation of species' traits (Owens and Bennett 2000). Finally, phylogenetic diversity should be the least sensitive of the three metrics, as the loss of (even many) closely related species has relatively little impact on overall phylogenetic diversity (Frishkoff et al. 2014).

Here we provide an empirical assessment of the influence of matrix composition on taxonomic, functional, and phylogenetic extinction thresholds. We do this through a well-replicated and spatially-extensive sample of avian diversity in 23 independent landscapes, with habitat patches embedded in either lowerpermeability matrix (cattle pasture), or higher-permeability matrix (sun coffee plantations) in southeastern Brazil. We test two central hypotheses: (1) that lowerpermeability matrix is associated with more abrupt species loss than higherpermeability matrix (Fig. 1A), and (2) that thresholds of taxonomic, functional, and phylogenetic diversity occur in distinct amounts of remaining native habitat (Fig. 1B).
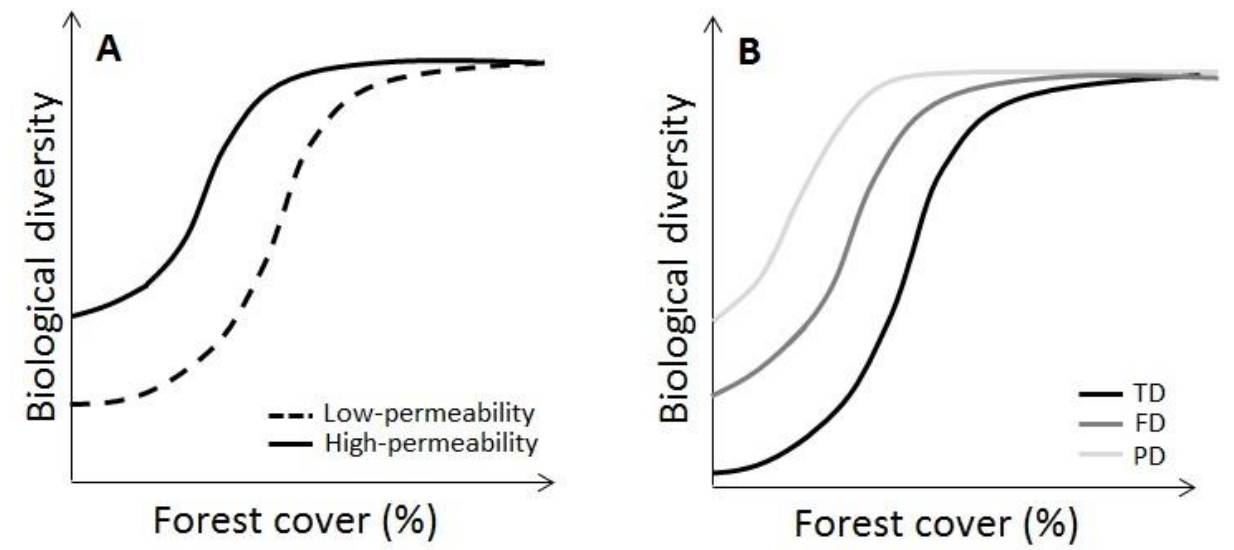

Figure 1. Expected relationships between forest cover and phylogenetic (PD), functional (FD), and taxonomic diversity (TD) of avian communities according to matrix type (A) and diversity metric (B). In A we hypothesize that biodiversity thresholds will occur first for all of the diversity metrics (TD, FD, PD) in low-permeability matrix (dashed lines) when compared with high-permeability 
matrix (straight lines). In B, we hypothesize that TD is lost earlier along the forest cover gradient, followed by FD and lastly by PD.

\section{Methods}

Study region: The study was conducted in two regions of $2,000-3,000 \mathrm{~km}^{2}$ each (Fig. 2) within the Brazilian Atlantic Rainforest, one of the world's most biodiverse and endangered ecosystems (Myers et al. 2000, Brooks et al. 2002, Ribeiro et al. 2011). In one region, the matrix is primarily composed of unmanaged cattle pastures owned by small landholders (lower-permeability matrix), while the other region has a matrix dominated by sun-coffee plantations (higher-permeability matrix), and lies in one of the most productive coffee regions in the world (CONAB 2013). The study region has a subtropical climate (UNICAMP 2016), with annual mean temperature varying from $11.3^{\circ} \mathrm{C}$ (minimum, in the colder season AprilSeptember) to $27.7^{\circ} \mathrm{C}$ (maximum, in the warmer season October-March), annual rainfall varying between 1,350 and 2,000 $\mathrm{mm}$ (Pompeu et al. 2009), and an elevation between 700-1700 m (Oliveira and Fontes 2000). Currently, the majority of the region's remaining tropical forest has been reduced to small fragments $(<50$ ha) in different stages of regeneration (Ribeiro et al. 2009).

Landscape selection: We used the landscape selection approach of Pasher et al. (2013) to select independent landscapes that span a large range of landscape-level forest cover, while controlling for potentially confounding factors. We identified a total of 23 circular landscapes ( $2 \mathrm{~km}$ radius, or 1,256 ha), where each landscape was constrained between 800 and 1,300 m.a.s.l, with ferric red latosol or argisol soil, and where either extensive cattle production or sun coffee plantation was the predominant matrix land-use type (lower-permeability pasture matrix; $\mathrm{N}=13$; higher-permeability coffee matrix; N=10; Fig. S1). We excluded major interstate highways and water reservoirs from focal landscapes and maintained a minimum distance of $6 \mathrm{~km}$ between the centroid of landscapes. Land-use in each $2 \mathrm{~km}$ focal landscape was mapped using high-resolution images (ArcGis 10.3 basemap imagery, DigitalGlobe satellites 2010-2011) with a reference scale of 1:5,000. Our final focal landscapes ranged from 6 to $54 \%$ of forest cover within the 2 -km radius. Landscape-level forest cover did not vary more than $5 \%$ within 1,2 , or $3-\mathrm{km}$ radii, 
based on each landscape's centroid, showing that our landscape selection and forest-cover landscape ranking were little affected by landscape extent.
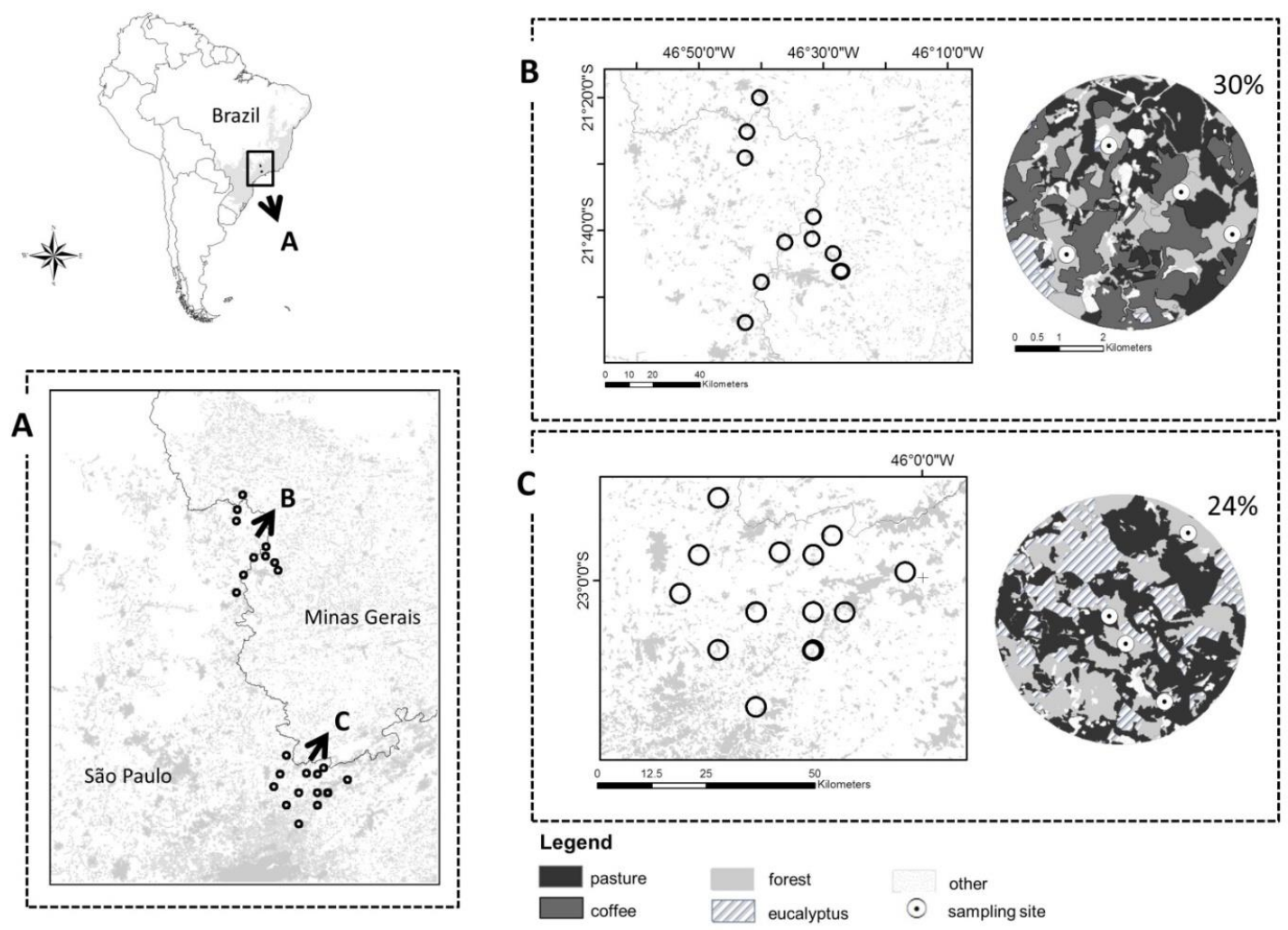

Figure 2. Study areas in the Brazilian Atlantic Rainforest domain (shaded area) between states of São Paulo and Minas Gerais (A). Landscapes with higher-permeability matrix (sun coffee plantation) are in the North (B) and low-permeability matrix (cattle pasture) are in the South (C). In both panels, we highlight the land use and distribution of sampling sites.

Study sites: To realistically reflect the distribution of forest across fragment sizes, we used a stratified random proportional design based on the largest fragment size to select the placement of four sampling sites in forest patches within each of the 23 focal landscapes $(\mathrm{N}=92)$. We calculated the percentage of total forest cover represented by the largest forest fragment in each landscape and allocated that proportion of sampling sites to that fragment. For instance, if the largest fragment contained $50 \%$ of the landscape forest cover, $50 \%$ of sampling sites $(\mathrm{N}=2)$ were located at this fragment, and 50\% randomly distributed across the remaining forest fragments larger than 2.5 ha. For each selected forest patch, we randomly selected a point along the forest-matrix interface and placed a sampling site $100 \mathrm{~m}$ 
(100.92 \pm 12.97$)$ from the edge within forest patch. All sampling sites were spaced a minimum of $800 \mathrm{~m}$ apart (1,591 \pm 621 ; Fig. 2$)$.

Bird sampling: In each sampling site, we performed $50 \mathrm{~m}$ fixed-radius point count (Blondel et al. 1970, Bibby et al. 2002) and recorded all bird species detected visually or orally during a $15 \mathrm{~min}$ sampling period. Studies in tropical regions indicate that 10 min point counts are enough to record $90 \%$ of tropical bird species (Esquivel and Peris 2008, Cavarzere et al. 2012). Bird species needed to be perched or singing inside the radius of detection to be recorded, and species flying above the canopy or flying through the sample area were not recorded (Bibby et al. 2002). All point counts were performed in the four hours after sunrise and in the last hour before sunset (Lynch 1995). Each point count was sampled in different times during the morning and evening periods in order to give the same chance of detection for all species. To increase detectability of more cryptic and rare species, each point count was replicated four times, between January-April and AugustNovember of 2014 (23 landscapes, 92 sampling sites, $\mathrm{N}=368$ point counts). All point counts were performed by the same observer (A.L.B).

We restricted our analysis to forest-dependent species (Sick 1997, del Hoyo et al. 2014), as these are the species of conservation concern that predominantly respond to native habitat loss. Forest-dependent species were considered those species dependent of forest environments to breeding and survive (Sick 1997, del Hoyo et al. 2014). We quantified bird abundance with the Punctual Abundance Index (PAI), the most common index to quantify bird abundance in Neotropical regions (Blake 2007). The PAI was calculated as the number of detections of a given species in a given sampling site, divided by the total number of point counts (Blondel et al. 1970).

Functional trait selection: We collected information on four avian functional traits (Sick 1997, del Hoyo et al. 2014), three related to extinction-proneness associated with habitat loss (7 levels in 3 traits; McKinney 1997), and one related to resource use (6 levels). Extinction proneness traits included body mass, clutch size, and nest type. For resource use, we measured diet (insectivorous, frugivorous, granivorous, nectivorous, carnivorous, or herbivorous), performing a ranking of intensity of 
resource use for each species as per De Coster et al. (2015) according to information available from the literature (Sick 1997, del Hoyo et al. 2014). For species with missing information, we took data for the most closely-related congener. More detail on traits selection and ranking of resources use is available in SOM1, and all traits values are available in Table S1.

Taxonomic richness: We defined taxonomic diversity (TD) as the total number of bird species (i.e. species richness) recorded in each sampling site.

Functional diversity: Because different functional traits may have values spanning several orders of magnitude, we first scaled trait values to avoid a single trait dominating trait diversity values (Villeger et al. 2008, Swenson 2014). We then performed a PCoA ordination to eliminate trait redundancy and included in our calculations those principal components explaining the majority (more than 95\%) of variation. Finally, we estimated functional diversity using Rao's quadratic entropy, which is the sum, across species pairs, of the product of the distance between the two species in trait space and their two relative abundances (FD; Botta-Dukat 2005). Functional diversity was calculated using "FD" package (Laliberté et al. 2015). Rao's quadratic entropy is influenced by both speciesabundance based diversity and differences among species, and it does not correlate with species richness (Botta-Dukat 2005).

Phylogenetic diversity: We calculated phylogenetic diversity (PD) using Faith's Index which provides a simple measure of the phylogenetic relatedness of a community based on the sum of all branch lengths in a phylogeny (Faith 1992, Thompson et al. 2015) using "Picante" package (Kembel et al. 2010) and the mean of 300 random phylogenetic trees. We obtained phylogenetic trees using backbone trees (BirdTree.org; Jetz et al. 2012, Jetz et al. 2014) derived from established deep avian relationships (Hackett et al. 2008; for further details, see Jetz et al. 2014). We used the total number of species in the whole sampling pool for each region as species pool. As PD frequently correlates with species richness, we also measured the standardized effect size ( $\mathrm{PD}_{\text {ses }}$ ) of phylogenetic community (Webb 2000, Pavoine and Bonsall 2011), which describes the difference between phylogenetic 
distances in observed communities and null communities where taxa labels were shuffled across the tips of the phylogenetic tree 999 times (Swenson 2014). PD ses can be interpreted in terms of which processes are important in community assembly. Positive $\mathrm{PD}_{\text {ses }}$ indicates phylogenetic evenness (i.e. a greater phylogenetic distance among co-occurring species) and indicates that competition is the main process driving the phylogenetic structure of communities (Swenson 2014). Negative $\mathrm{PD}_{\text {ses }}$ indicates phylogenetic clustering (i.e. a smaller phylogenetic distances among co-occurring species than expected by chance), and indicates an environmental filter structuring phylogeny (Swenson 2014).

Data analysis: All analyses were conducted in the R environment, version 3.3.1 (R Development Core Team 2016). To first assess the differences among ranges and central tendencies of $\mathrm{TD}, \mathrm{FD}, \mathrm{PD}$, and $\mathrm{PD}_{\text {ses, }}$ metrics were pooled across all landscapes within both matrix types (pasture and coffee plantations) and we performed an independent paired t-test following data normality and homogeneity assumptions using "stats" package (R Development Core Team 2016). We assessed phylogenetic signal for all functional traits using Pagel's $\lambda$ (Pagel 1999) and the "phytools" package (Revell et al. 2008) in order to determine how trait variation is correlated with phylogenetic relatedness of species. Phylogenetic signal can be defined as the statistical non-independence among trait values due their phylogenetic relatedness (Revell et al. 2008)

To test our first hypothesis that lower-permeability matrices (i.e. pasture matrices) are associated with abrupt species loss at higher levels of native habitat compared to higher-permeability matrices, we built three predictive models in response to forest cover for each biodiversity index (TD, FD, $P D, P D_{\text {ses}}$ ): a generalized linear mixed model (LR), a piecewise mixed model (PR), and a null mixed model (Null). Metrics were modeled using appropriate error distributions (Poisson for TD and Gaussian for FD, PD, and $\mathrm{PD}_{\text {ses }}$ ), and focal landscape identity was used as random factor in all models. To identify the best predictive model, we performed a model selection procedure based on Akaike Information Criterion (AICc) corrected for small samples (Burnham \& Anderson 2002), in which we compared AICc model weights across models. We considered those models with a $\triangle \mathrm{AICc}$ below two as having the strongest empirical support (Burnham and 
Anderson 2002). We used packages "bbmle" (Bolker 2016), "lme4" (Bates et al. 2016), and "segmented.lme" (Muggeo et al. 2014).

We used the forest cover amount in an $800 \mathrm{~m}$ radius around each sampling site as our predictor variable because this is the scale that reflects bird species response to both patch and landscape scale (Boscolo and Metzger 2009, BanksLeite et al. 2011). Data on the movement of Brazilian Atlantic Forest birds revealed that most movements (85\%) occur within $400 \mathrm{~m}$ from the focal site within the same forest fragment, and 15\% occur within up to $1000 \mathrm{~m}$ (Marini 2010), supporting the use of $800 \mathrm{~m}$ radius scale. Previous results suggest that $800 \mathrm{~m}$ scale strongly reflects species response to landscape configuration, as we are focusing in a subset of forest-dependent species, mostly Passeriformes, with reduced dispersal distances, and small territories (Lira et al. 2012).

To test our second hypothesis that thresholds for taxonomic, functional, and phylogenetic diversity occur in distinct amounts of remaining native habitat, we used the estimated breakpoints given by the piecewise regression models. Piecewise regression models permit the estimatation of biodiversity thresholds by splitting explanatory variables (i.e. forest cover) in two or more linear regressions and locating where the linear trends change (Muggeo et al. 2014). Thresholds and respective confident intervals were obtained giving several starting points to the piecewise model in order to obtain those estimated values with lowest loglikelihood (Muggeo et al. 2014).

\section{Results}

Despite recording more forest-dependent species overall (a higher gamma diversity) in patches embedded in pasture matrix (85 species compared to 71 species in coffee matrix; Table S1), we found that matrix composition affects each of the diversity metrics differently. TD was higher in patches embedded in coffee matrices $(\mathrm{t}=4.19, \mathrm{df}=88.97, \mathrm{p}<0.001$; Fig. 3), while neither PD nor FD varied significantly between matrices (PD: $t=-1.356 ; d f=86.85 ; p=0.178 ; F D: t=0.258 ; d f$ $=89.78 ; \mathrm{p}=0.796)$. In general, there was a strong phylogenetic signal among species' trait values $(\lambda>0.67 ; p<0.01$; Table $S 2)$, resulting in moderate correlation between FD and PD in both coffee and pasture matrices $(r=0.68$ and $r=0.69$ respectively; Fig. S2A), and similar patterns of ranges and central tendencies of FD 
and PD (Fig. 3). Moreover, matrix composition also affected $\mathrm{PD}_{\text {ses: }}$ there was a stronger phylogenetic clustering of assemblages (i.e. a smaller phylogenetic distance among co-occurring species than expected by chance) in patches embedded in coffee matrices $(t=4.61, d f=73.8, p<0.001$; Fig. 3$)$, while values did not differ from what would be expected by chance in pasture matrices $\left(\mathrm{PD}_{\mathrm{ses}}=0\right)$. All calculated indexes are in Table S3.
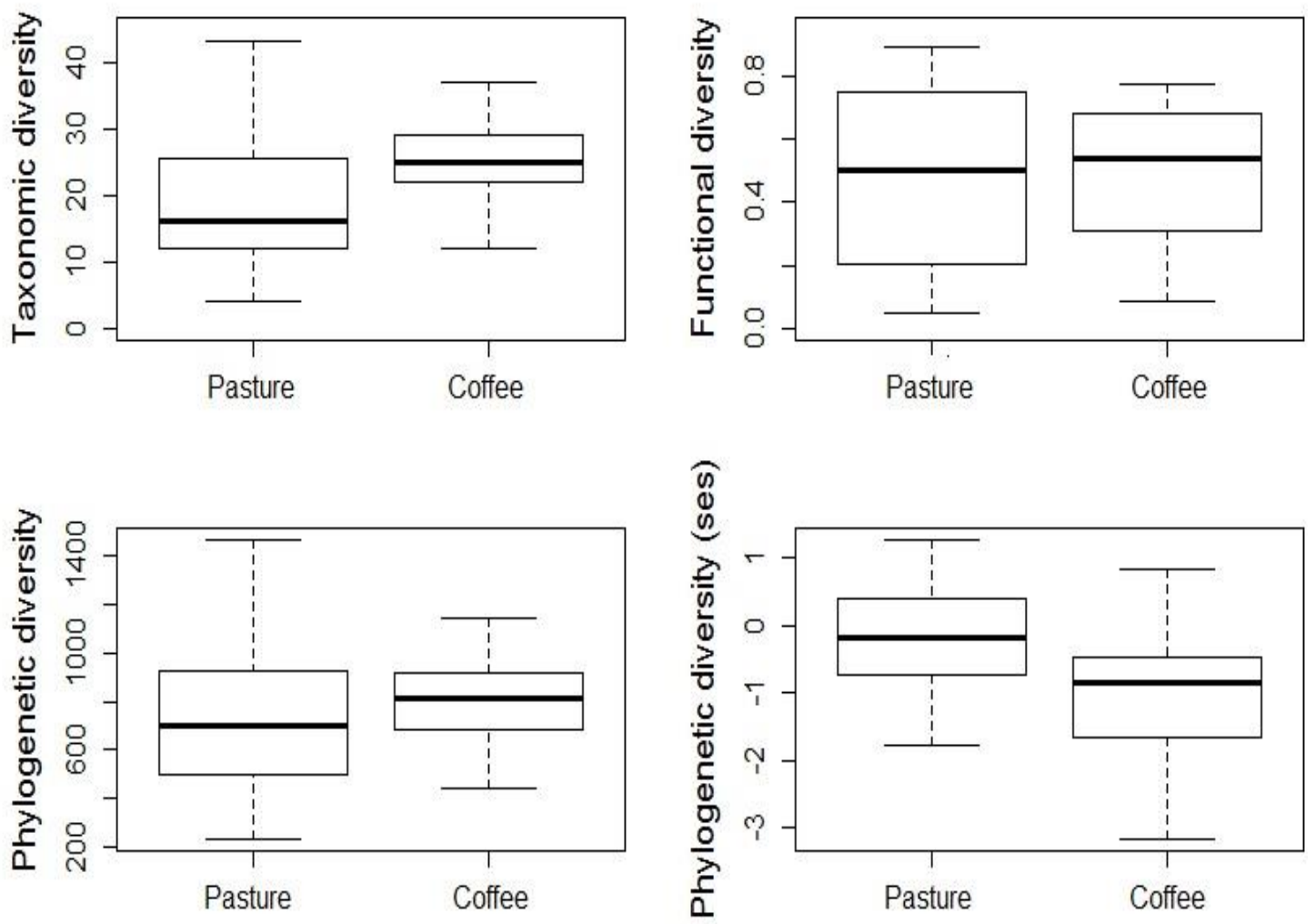

Figure 3. Central tendencies and ranges of taxonomic (TD), functional (FD), and phylogenetic (PD and $\mathrm{PD}_{\mathrm{ses}}$ ) avian diversity according matrix type (pasture and coffee plantations).

We found that different diversity metrics responded differently to habitat loss. A non-linear relationship with forest cover was found for TD and PD, while no clear relationship was observed for FD and $\mathrm{PD}_{\text {ses }}$ (Table 1). The best fitted model for TD in both matrices was the piecewise regression (Table 1). In patches embedded in coffee matrices, we found a taxonomic threshold at 19\% remaining habitat (confident interval; CI: 11.7-23.4), with species loss occurring in a rate of 0.08 species per percent unit of forest cover before the threshold and increasing to 0.92 after the threshold (Table 1; Fig. 4A). For patches embedded in pasture matrices, the TD threshold occurred at 34\% remaining habitat (CI: 25.1-43.4), with 
species loss occurring in a rate of 0.14 species per unit of forest cover before the threshold and a more gradual reduction compared to coffee matrices $(b=0.51)$ below the threshold. We noticed that $60 \%$ of all bird species in the measured species pool were lost below the threshold in pasture matrices, and $30 \%$ were lost below the threshold in coffee matrices (Fig. 4B).
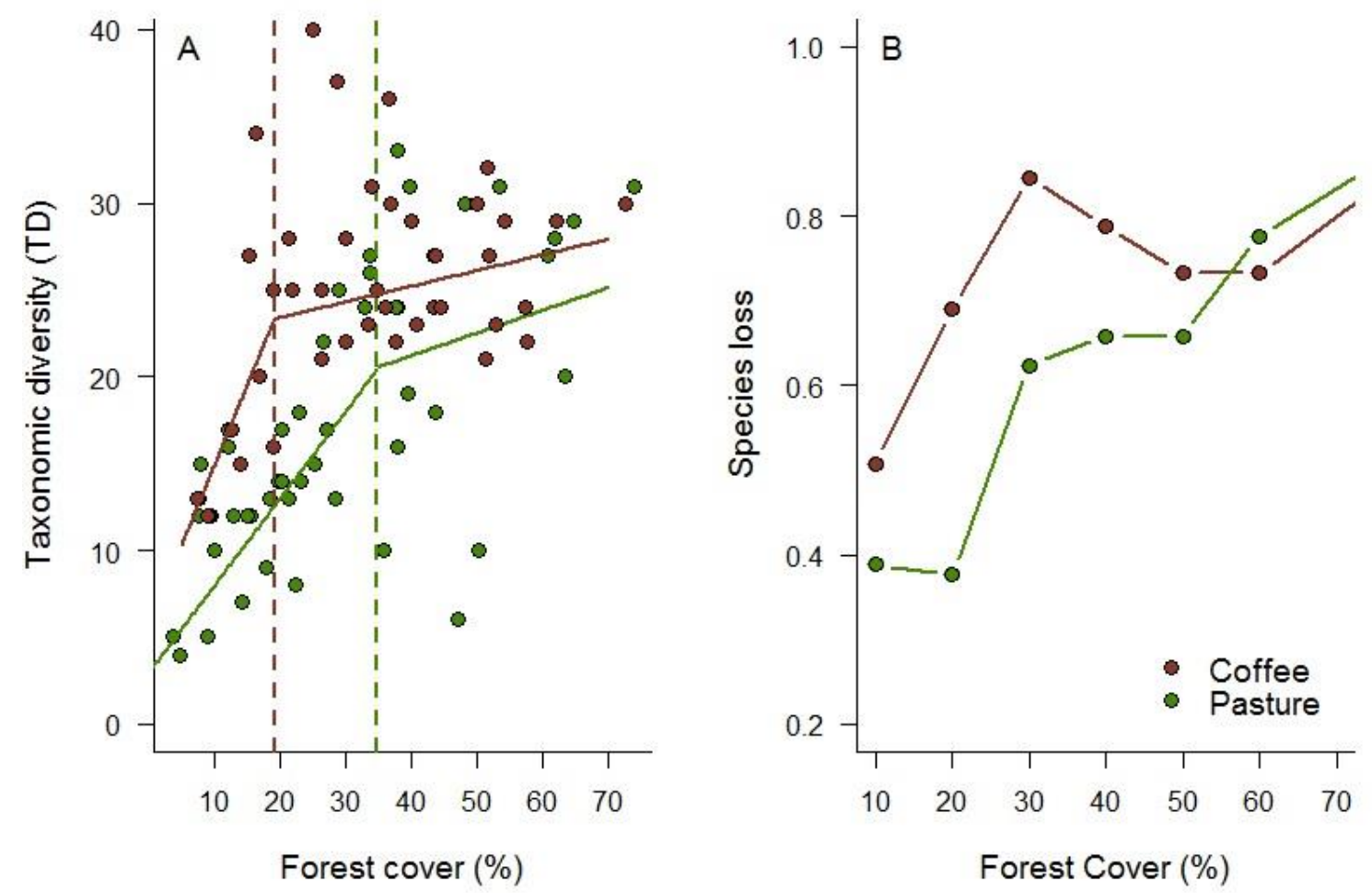

Figure 4. Fitted piecewise regressions for taxonomic diversity according matrix type (pasture and coffee plantations) (A), and species loss (normalized) in relation to regional species pool (B).

The best fitting model for PD in both matrices was also the piecewise model (Table 1). However, we found no statistical difference between thresholds for PD in the two matrices (Table 1; Fig. 5A), and a strong correlation between PD and TD in both coffee ( $\mathrm{r}=0.87$ ) and pasture matrices $(\mathrm{r}=0.97$; Fig. S2B). In both matrix contexts, the estimated thresholds for PD were close the estimated values for TD (22\% for coffee matrices and 29\% for pasture matrices). Phylogenetic diversity in patches embedded in coffee matrices is lost at a rate of 264,000 evolutionary years per unit of forest cover (percent) before the phylogenetic threshold (22\%; CI: 7.0441.1 ), but the rate increases to 277,890 after the threshold. For patches embedded in pasture matrices, PD decreases at a similar rate of 275,540 evolutionary years per forest cover unit before the phylogenetic threshold (29\%; CI: 11.7-46) which 
increases to 286,700 below the threshold (29\%). Unlike PD, our other measure of phylogenetic diversity that corrected for correlation with species richness $\left(\mathrm{PD}_{\mathrm{ses}}\right)$ exhibited no relationship with forest cover (Table 1), but has shown a substantial difference in $\mathrm{PD}_{\text {ses }}$ according to matrix composition (Fig. 3; Fig. 5B).
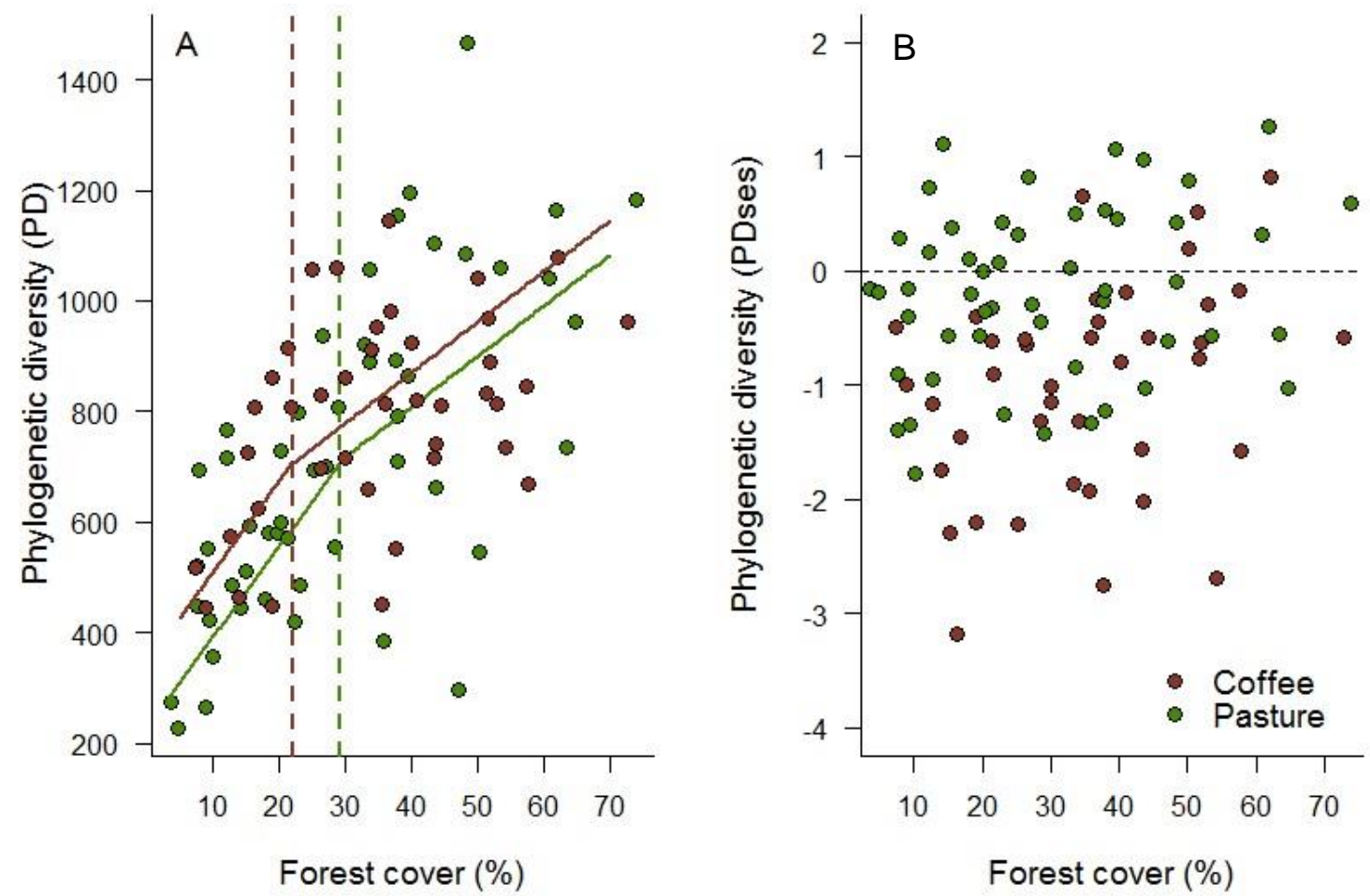

Figure 5. Fitted piecewise regressions for phylogenetic diversity (PD) according matrix type (pasture and coffee plantations) (A). $\mathrm{PD}_{\text {ses }}$ values according matrix type (B). Values above 0 indicate that competition is the main driver of phylogenetic structure of bird assemblages; values below 0 indicate an environmental filter.

Finally, even though traits all showed a moderate phylogenetic signal, and therefore FD could have been expected to behave like PD, no relationship between FD and forest cover was detected (Table 1). However, there is an evident reduction in FD below 20\% remaining native habitat in both matrices (Fig. 6). Seed dispersers, insectivorous, and ecosystem engineers (i.e. species that contribute modifying the environment that most times brings benefits for other species) are reduced by 90,50 , and $65 \%$ respectively in pasture matrices, and by in 50,40 , and $40 \%$ in coffee matrices (Fig. S3). Birds of prey are completely lost in both matrices below this threshold. 


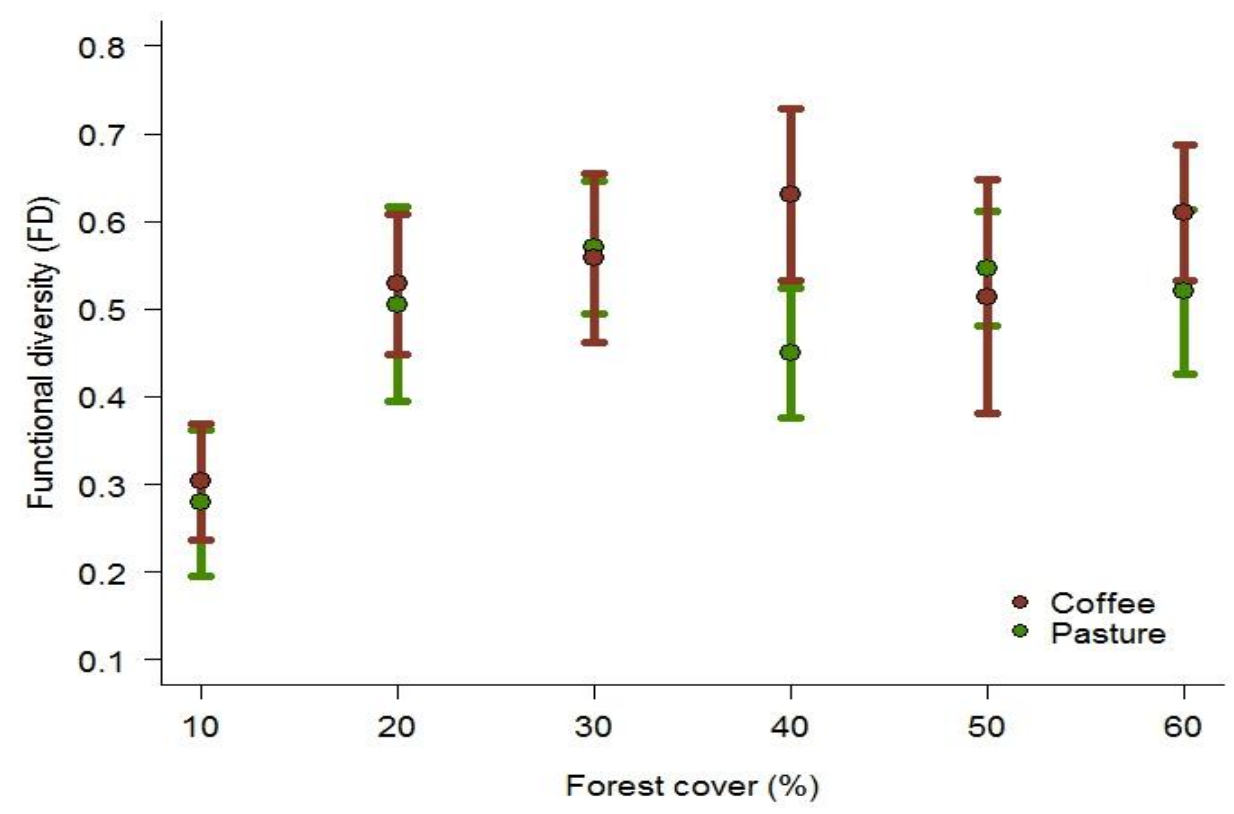

Figure 6. Mean and standard error of functional diversity (FD) in response to habitat loss according matrix type (pasture and coffee plantations).

\section{Discussion}

Through a large, comparative landscape field study, we found evidence for a strong influence of matrix composition on different diversity indexes, supporting at least partially our first hypothesis. Coffee matrices are able to maintain higher avian taxonomic diversity in forest patches in landscapes with smaller amounts of remaining forest cover than pasture matrices. As a result, the threshold for taxonomic diversity occurs at a lower amount of habitat cover in coffee matrices (ca. 20\%) compared to pasture matrices (ca. 35\%). Secondly, we also found partial support for our hypothesis that TD, PD, and FD are differentially influenced by forest cover loss. However, the order in which each type of diversity is lost is not what we predicted, and is dependent on matrix type. In habitat patches embedded in pasture matrices, TD and PD are lost practically at same time (probably due its correlation), and FD is lost later in the habitat loss process, while all diversity indexes seem be lost at same time (ca. 20\%) in patches embedded in coffee matrices. In addition, a strong phylogenetic clustering (negative values of $\mathrm{PD}_{\mathrm{ses}}$ ) in coffee matrices suggests an environmental filter structuring the phylogenetic structure of bird assemblages that might be a result of the deforestation and 
fragmentation history of the region. Finally, even though null model was the best predictor of FD in both matrices, there is a substantial reduction on FD below 20\% of habitat remaining, which has implications in terms of ecosystem functioning. Our study is novel, contributing to the understanding of matrix composition as an important driver not only of patterns in biodiversity, but also of threshold dynamics in fragmented landscapes.

We found that matrix composition strongly affects biodiversity patterns within habitat patches, corroborating at least partially, our first hypothesis that more contrasting matrices are associated with abrupt species loss at higher levels of native habitat- at least for TD. Matrix might affect in-patch diversity in three ways at least. First, as inter-patch movement of organisms can be affected by different land-use types (Ricketts 2001, Ruffell et al. 2016, Prevedello et al. In press), matrix quality may be even more important than size and spatial arrangement of remnant patches in maintaining landscape connectivity (Tubelis et al. 2007, Driscoll et al. 2013). A higher-contrasting matrix, such as a cattle pasture, can strongly prevent avian dispersal among patches and consequently increase extinction rates in-patches, while reducing (re) colonization rates (Horner-Devine and Bohannan 2006, Webb et al. 2006). Second, even though the strongest effect of matrix composition on biodiversity is the way it regulates dispersal and movement and therefore drives colonization and extinction processes (Antongiovanni and Metzger 2005, Castellon and Sieving 2006, Neuschulz et al. 2013), matrix composition also plays important role modulating microclimate conditions at habitat edges (Saunders et al. 1991) and consequently might changes native species survival and reproductive success (Ewers and Didham 2006). Finally, the matrix surrounding habitat patches might function as source of additional nesting and foraging resources (Dunning et al. 1992, Ewers and Didham 2006, Caryl et al. 2012) and regulates the cross-habitat spillover between native and matrix habitats (Estavillo et al. 2013, Boesing et al. In prep). However, once habitat loss reaches the critical $20 \%$ threshold, even matrix composition cannot postpone species loss, and community stability is compromised. 
Table 1. Model selection evaluating the response of taxonomic (TD), functional (FD), and phylogenetic diversity (PD, $\mathrm{PD}$ ses) to forest cover (fc) according to matrix composition (pasture or coffee plantations). Model type indicates the model (PR: piecewise mixed model; LR: generalized linear mixed model; Null: null mixed model); AICc corresponds to Akaike information criteria corrected to small samples; $\triangle \mathrm{AICc}$ is the difference between AICc from the best ranked model ( $\triangle \mathrm{AICc}$ ); AICc $\omega \mathrm{i}$ is the evidence weight; $\mathrm{df}$ is the degrees of freedom. Var1 (b) corresponds to the slope of regression (and in case of PR, the slope before threshold); Var2(c) is always the slope after the thresholds in a PR. Threshold (U) corresponds to estimated threshold given by the PR.

\begin{tabular}{|c|c|c|c|c|c|c|c|c|c|}
\hline \multirow[b]{3}{*}{ Models } & \multirow[b]{3}{*}{$\begin{array}{l}\text { Model } \\
\text { type }\end{array}$} & \multirow[b]{3}{*}{ AICc } & \multirow[b]{3}{*}{$\Delta \mathrm{AIC}$} & \multirow[b]{3}{*}{ df } & \multirow{2}{*}{\multicolumn{4}{|c|}{ Coefficients }} & \multirow{3}{*}{$\begin{array}{l}\text { Threshold } \\
\mathbf{U}\end{array}$} \\
\hline & & & & & & & & & \\
\hline & & & & & AICc $\omega \mathrm{i}$ & Intercept (se) & Var1 (b) & $\operatorname{Var} 2$ (c) & \\
\hline \multicolumn{10}{|l|}{ Taxonomic diversity } \\
\hline \multicolumn{10}{|l|}{ Pasture matrix } \\
\hline $\mathrm{TD} \sim \mathrm{fc} *(\mathrm{fc}<\mathrm{U})+\mathrm{fc}^{*}(\mathrm{fc}>\mathrm{U})$ & PR & 329.8 & 0 & 6 & 0.963 & $19.74(n a)$ & 0.51 (na) & -0.370 (na) & $34.7(25.0-43.4)$ \\
\hline $\mathrm{TD} \sim \mathrm{fc}$ & LR & 336.3 & 6.5 & 3 & 0.037 & $2.812(0.074)$ & $0.223(0.041)$ & - & - \\
\hline TD $\sim$ Null & Null & 362.2 & 32.4 & 2 & $<0.001$ & $2.824(0.107)$ & - & - & - \\
\hline \multicolumn{10}{|l|}{ Coffee matrix } \\
\hline $\mathrm{TD} \sim \mathrm{fc} *(\mathrm{fc}<\mathrm{U})+\mathrm{fc}^{*}(\mathrm{fc}>\mathrm{U})$ & $\mathrm{PR}$ & 201.7 & 0 & 6 & 0.937 & 24.24 (na) & 0.920 (na) & -0.832 (na) & $19.1(11.7-23.4)$ \\
\hline $\mathrm{TD} \sim \mathrm{fc}$ & LR & 207.1 & 5.4 & 3 & 0.062 & $3.174(0.034)$ & $0.123(0.034)$ & - & - \\
\hline TD $\sim$ Null & Null & 216.3 & 14.6 & 2 & $<0.001$ & $3.180(0.043)$ & - & - & - \\
\hline
\end{tabular}

\section{Phylogenetic diversity}

Pasture matrix

PD fc $*($ fc $<\mathrm{U})+\mathrm{fc}^{*}(\mathrm{fc}>\mathrm{U})$

$\mathrm{PD} \sim \mathrm{fc}$

$\mathrm{PD} \sim$ Null 


\begin{tabular}{|c|c|c|c|c|c|c|c|c|c|}
\hline $\mathrm{PD} \sim \mathrm{fc}$ & LR & 430.4 & 4.6 & 4 & 0.092 & $784.20(31.11)$ & $101.27(25.24)$ & - & - \\
\hline $\mathrm{PD} \sim$ Null & Null & 450.1 & 24.3 & 3 & $<0.001$ & $782.3(38.2)$ & - & - & - \\
\hline \multicolumn{10}{|l|}{ Phylogenetic diversity (ses) } \\
\hline \multicolumn{10}{|l|}{ Pasture matrix } \\
\hline $\mathrm{PD}_{\text {ses }} \sim$ Null & Null & 122.7 & 0 & 3 & 0.77 & $-0.173(0.122)$ & - & - & - \\
\hline $\mathrm{PD}_{\text {ses }} \sim \mathrm{fc}$ & LR & 125.2 & 2.5 & 4 & 0.23 & $-0.175(0.108)$ & $0.158(0.105)$ & & \\
\hline $\mathrm{PD}_{\mathrm{ses}} \sim \mathrm{fc} *(\mathrm{fc}<\mathrm{U})+\mathrm{fc}^{*}(\mathrm{fc}>\mathrm{U})$ & PR & - & - & - & & - & - & - & - \\
\hline \multicolumn{10}{|l|}{ Coffee matrix } \\
\hline $\mathrm{PD}_{\text {ses }} \sim$ Null & Null & 123.2 & 0 & 3 & 0.72 & $-0.179(0.105)$ & - & - & - \\
\hline $\mathrm{PD}_{\text {ses }} \sim \mathrm{fc}$ & LR & 125.1 & 1.9 & 4 & 0.28 & $-0.179(0.103)$ & $0.176(0.104)$ & - & - \\
\hline $\mathrm{PD}_{\mathrm{ses}} \sim \mathrm{fc} *(\mathrm{fc}<\mathrm{U})+\mathrm{fc}^{*}(\mathrm{fc}>\mathrm{U})$ & PR & - & - & - & - & - & - & - & - \\
\hline \multicolumn{10}{|l|}{ Functional diversity } \\
\hline \multicolumn{10}{|l|}{ Pasture matrix } \\
\hline FD Null & Null & 21.3 & 0 & 3 & 0.61 & $0.491(0.051)$ & - & - & - \\
\hline $\mathrm{FD} \sim \mathrm{fc} *(\mathrm{fc}<\mathrm{U})+\mathrm{fc}^{*}(\mathrm{fc}>\mathrm{U})$ & PR & 23.5 & 2.2 & 6 & 0.2 & 1.199 (na) & 0.813 (na) & -0.046 (na) & $15.84(9.3-22.6)$ \\
\hline $\mathrm{FD} \sim \mathrm{fc}$ & LR & 23.6 & 2.3 & 4 & 0.19 & $0.491(0.039)$ & $0.095(0.037)$ & - & - \\
\hline \multicolumn{10}{|l|}{ Coffee matrix } \\
\hline FD Null & Null & 1.6 & 0 & 3 & 0.875 & $0.478(0.046)$ & - & - & - \\
\hline $\mathrm{FD} \sim \mathrm{fc}$ & LR & 5.5 & 3.9 & 4 & 0.122 & $0.478(0.047)$ & $0.064(0.003)$ & - & - \\
\hline $\mathrm{FD} \sim \mathrm{fc} *(\mathrm{fc}<\mathrm{U})+\mathrm{fc}^{*}(\mathrm{fc}>\mathrm{U})$ & PR & 14.1 & 12.6 & 6 & 0.001 & 0.758 (na) & 0.318 (na) & $-0.019(\mathrm{na})$ & $22.76(8.2-37.2)$ \\
\hline
\end{tabular}


Differences in community structure in both matrix types might explain why the indices are all lost at same time in coffee matrices, while TD and PD are lost before FD in pasture matrices. Distinct deforestation and fragmentation histories and the absence of a source of colonizers might be lead to higher similarity among communities in patches embedded in coffee matrices than pasture matrices (Fig. S4). Landscapes with pasture matrices are located in a region surrounded by large forest remnant along the Cantareira and Mantiqueira mountains region, and might be more easily colonized or recolonized by species from adjacent regions. This could potentially lead to what we observed: more diverse clades and a higher phylogenetic distance among species in pasture matrices than in coffee matrices. This higher heterogeneity in bird composition in pasture matrices could explain why TD and PD are lost before FD, as species can be lost without losing functions, while in more homogeneous assemblages (coffee matrices) all indexes are lost around $20 \%$ of habitat remaining.

In spite of the fact that the ranges and central tendencies of total evolutionary history (PD) are similar between regions - especially due its correlation with $\mathrm{TD}$, the strong phylogenetic clustering $\left(\mathrm{PD}_{\mathrm{ses}}\right)$ in coffee matrices indicates a regional filter controlling the phylogenetic structure of bird communities. One reason for this clustered pattern in coffee plantations could be the historical context of fragmentation that carried a regional extinction of more distinctive species, leading to a higher phylogenetic similarity due the presence of closely related species with similar traits, and that are similarly adapted to this new condition (Cavender-Bares et al. 2009). While species distributions are determined largely by biogeographical processes, environmental filters are fundamental in determining species persistence at smaller spatial scales (Cavender-Bares et al. 2009). In addition, habitat loss and fragmentation might favor persistence of subsets of related clades that can thrive in highly disturbed and deforested landscapes (Frishkoff et al. 2014), and therefore particular branches of the phylogeny are at greater risk than others (Purvis et al. 2000). This pattern highlights the importance of maintaining more permeable matrices in order to increase species dispersal and movement, and also how important is to maintain large blocks of habitat that can act as a source of colonizers to increase community heterogeneity in fragmented landscapes. 
Even though FD does not follow the same pattern as TD and PD, with clear thresholds along the habitat loss gradient in both matrices, there is a substantial reduction in FD below 20\% remaining habitat in both matrices. The absence of an FD threshold might be a function of at least two factors. First, species turnover might be occurring, allowing different species performing similar functions to persist in altered forest patches (Banks-Leite et al. 2012, Dornelas et al. 2014), obscuring thresholds. Previous studies highlight that species may be lost without losing functions (Luck et al. 2013, De Coster et al. 2015), particularly when communities have significant amounts of functional trait redundancy (Fonseca and Ganade 2001). Second, the absence of threshold for FD might be due to the functional diversity metric used. Different functional indexes have different drawbacks and strengths (Cianciaruso et al. 2009). As Rao's entropy do not correlate with species richness and instead takes into account bird abundance (Botta-Dukat 2005), we expected it to be the most appropriate for this purpose; however, the choice of another metric might have revealed another pattern.

\section{Implications for conservation}

Our study demonstrates that matrix composition strongly affects in-patch assemblages of birds in the Brazilian Atlantic forest. This is the first empirical study demonstrating that less contrasting matrices might postpone abrupt loss of species from a threshold of $35 \%$ of forest cover to $20 \%$. This strong influence of the matrix on in-patch diversity has important implications for conserving biodiversity in fragmented landscapes (Ruffell et al. 2016, Prevedello et al. In press, Prevedello and Vieira. 2010). Increasing matrix permeability through land uses that provide substantial resources, facilitates dispersal, and create lower-edge contrast (Kupfer et al. 2006) might reduce the impacts of habitat loss. However, since matrix management is constrained by both economic and social factors (Phalan et al. 2011), effective implementation of matrix management will require an interdisciplinary approach to harmonize biological needs with economic and social demands. Moreover, in terms of landscape management, it is important to understand how much matrix must be converted to high-quality uses in order to achieve conservation goals (Ruffell et al. 2016). Although the conversion of large 
areas of high-contrasting matrices to lower-contrasting matrices is most of the time unfeasible, even minor changes to a small proportion of matrix, such as the inclusion of stepping stones (Boscolo et al. 2008, Uezu et al. 2008, Saura et al. 2014) may be a an effective conservation strategy (Renjifo 2001, Ruffell et al. 2016). In a recent demonstration of this pattern, Ruffell and colleagues (2016) showed that in the absence of arboreal elements in the matrix, $60 \%$ of in-patch bird species were lost by habitat loss, while when the matrix had plantations (even exotic tree plantations), the loss was reduced to $15 \%$. Increasing landscape heterogeneity is a key management strategy, since complex-structured mosaics in spite to increase matrix suitability, it increases areas of contact between different habitats (Perovic et al. 2010) enhancing landscape connectivity and promoting long-term persistence in fragmented landscapes.

Increasing matrix permeability might not only guarantee species movement among patches, ensuring long-term persistence in fragmented landscapes, but also provide critical resources for some forest-dependent species that provide regulating ecosystem services (Sekercioglu et al. 2016), such as pest control and pollination in agricultural matrices (Bianchi et al. 2006, Blitzer et al. 2012, Naeem et al. 2012). The decrease in in-patch insectivorous might potentially affect pest control performed by avian predators-especially in coffee matrices where a substantial number of forest-dependent species often spill over into these plantations (Boesing et al. In prep). Many studies in both natural and managed areas demonstrate that birds not only have the potential to reduce herbivorous insect populations, but also that crops may respond with higher growth rates in the presence of avian predators (Whelan et al. 2008), increasing yield productivity (Johnson et al. 2009, Maas et al. 2013). In addition, frugivorous species are also strongly affected by habitat loss, and the absence or lower density of seeddispersing frugivores might cause a smaller fraction of the fruit crop to be dispersed, resulting in changes on plant composition (Jordano et al. 2011). Moreover, more than $90 \%$ of tropical woody plant species depend on frugivorous to support their life cycles, and the disappearance of frugivorous species could unleash a cascade of effects and substantial changes in structure and function of an ecosystem (Jordano 2016). 
For practical purposes, taxonomic diversity seems to be the best predictor index of loss in fragmented landscapes, since this is the first index to be affected especially in high-contrasting matrices - and therefore detecting a minimal habitat threshold cover for taxonomic diversity can prevent subsequent functional and phylogenetic loss. Our results highlight the need to maintain sustainable amounts of habitat cover above thresholds (35\% in the worse scenario) in order to maintain ecosystem functionality. Even though this threshold might not save most threatened species from extinction (Banks-Leite et al. 2014), it might prevent subsequent loss of functional and phylogenetic diversity. Importantly, once habitat loss reaches the critical $20 \%$ threshold, even a more permeable matrix cannot postpone species loss, and community stability is compromised.

Our results support the existence of a regime-shift occurring in avian community composition in heavily-deforested landscapes that is strongly modulated by matrix composition, and first detected by taxonomic diversity. We thus highlight the importance of considering matrix permeability and investigating different facets of biodiversity when evaluating the impacts of land use change on ecosystems composition and functions.

\section{Acknowledgements}

This study was developed within the Interface Project, supported by São Paulo Research Foundation (FAPESP, 2013/23457-6) and had additional support from Rufford Small Grant (14223-1). We thank Scott Robinson and Bob Holt for their contribution on bird classification and discussion about bird persistence in disturbed environments and Sieving's Lab for valuable discussions during the manuscript development. ALB was supported by doctoral fellowships from the Brazilian Ministry of Education (CAPES-DS; 2012-2013), the São Paulo Research Foundation (FAPESP, 2013/12777-0), and by National Council for Scientific and Technological Development (CNPQ, 207142/2014-9; 2015-2016). EN was supported by post-doctoral fellowships from the National Science Foundation (IRFP, 1158817) and the São Paulo Research Foundation (FAPESP, 2014/116768). JPM was funded by the Brazilian National Council for Scientific and Technological Development (CNPQ, 307934/2011-0). We are thankful to Kelley Langhans for careful English review. 


\section{Literature cited}

Andren, H. 1994. Effects of habitat fragmentation in birds and mammals in landscapes with different proportions of suitable habitat - a review. Oikos 71:355-366.

Antongiovanni, M. and J. P. Metzger. 2005. Influence of matrix habitats on the occurrence of insectivorous bird species in Amazonian forest framents. Biological Conservation 122:441-451.

Banks-Leite, C., R. M. Ewers, V. Kapos, A. C. Martensen, and J. P. Metzger. 2011. Comparing species and measures of landscape structure as indicators of conservation importance. Journal of Applied Ecology 48:706-714.

Banks-Leite, C., R. M. Ewers, and J. P. Metzger. 2012. Unraveling the drivers of community dissimilarity and species extinction in fragmented landscapes. Ecology 93:25602569.

Banks-Leite, C., R. Pardini, L. R. Tambosi, W. D. Pearse, A. A. Bueno, R. T. Bruscagin, T. H. Condez, M. Dixo, A. T. Igari, A. C. Martensen, and J. P. Metzger. 2014. Using ecological thresholds to evaluate the costs and benefits of set-asides in a biodiversity hotspot. Science 345:1041-1045.

Bates, D., M. Maechler, B. Bolker, S. Walker, R. H. B. Christensen, H. Singmann, B. Dai, G. Grothendieck, and P. Green. 2016. Ime4: Linear Mixed-Effects Models using 'Eigen' and S4. R package version 1.1-12.

Bender, D. J. and L. Fahrig. 2005. Matrix structure obscures the relationship between interpatch movement and patch size and isolation. Ecology 86:1023-1033.

Betts, M. G., G. J. Forbes, and A. W. Diamond. 2007. Thresholds in songbird occurrence in relation to landscape structure. Conservation Biology 21:1046-1058.

Bianchi, F. J. J. A., C. J. H. Booij, and T. Tscharntke. 2006. Sustainable pest regulation in agricultural landscapes: a review on landscape composition, biodiversity and natural pest control. Proceedings of the Royal Society B-Biological Sciences 273:1715-1727.

Bibby, C. J., N. D. Burgess, D. A. Hill, and S. H. Mustoe. 2002. Bird Census Techniques. Second Edition edition. Academic Press, London, UK.

Blake, J. G. 2007. Neotropical forest bird communities: A comparison of species richness and composition at local and regional scales. Condor 109:237-255.

Blitzer, E. J., C. F. Dormann, A. Holzschuh, A.-M. Klein, T. A. Rand, and T. Tscharntke. 2012. Spillover of functionally important organisms between managed and natural habitats. Agriculture Ecosystems \& Environment 146:34-43.

Blondel, J., C. Ferry, and B. Frochot. 1970. [The point count method to recording bird from hearing spots]. Alauda 38:55-71. 
Boesing, A. L., E. Nichols, and J. P. Metzger. In prep. How does landscape structure affects avian cross-habitat spillover?

Bolker, B. 2016. bbmle: tools for general maximum likelihood estimation. R package version 1.0.18. R package version 1.0.18.

Boscolo, D., C. Candia-Gallardo, M. Awade, and J. P. Metzger. 2008. Importance of interhabitat gaps and stepping-stones for lesser woodcreepers (Xiphorhynchus fuscus) in the Atlantic forest, Brazil. Biotropica 40:273-276.

Boscolo, D. and J. P. Metzger. 2009. Is bird incidence in Atlantic forest fragments influenced by landscape patterns at multiple scales? Landscape Ecology 24:907-918.

Botta-Dukat, Z. 2005. Rao's quadratic entropy as a measure of functional diversity based on multiple traits. Journal of Vegetation Science 16:533-540.

Bregman, T. P., C. H. Sekercioglu, and J. A. Tobias. 2014. Global patterns and predictors of bird species responses to forest fragmentation: Implications for ecosystem function and conservation. Biological Conservation 169:372-383.

Brooks, T. M., R. A. Mittermeier, C. G. Mittermeier, G. A. B. da Fonseca, A. B. Rylands, W. R. Konstant, P. Flick, J. Pilgrim, S. Oldfield, G. Magin, and C. Hilton-Taylor. 2002. Habitat loss and extinction in the hotspots of biodiversity. Conservation Biology 16:909-923.

Burnham, K. P. and D. R. Anderson. 2002. Model selection and multimodel inference. A practical information-theoritical approach. Springer, New York.

Caryl, F. M., C. P. Quine, and K. J. Park. 2012. Martens in the matrix: the importance of nonforested habitats for forest carnivores in fragmented landscapes. Journal of Mammalogy 93:464-474.

Castellon, T. D. and K. E. Sieving. 2006. An experimental test of matrix permeability and corridor use by an endemic understory bird. Conservation Biology 20:135-145.

Cavarzere, V., T. V. Vieira da Costa, and L. F. Silveira. 2012. On the use of 10-minute point counts and 10-species lists for surveying birds in lowland Atlantic forests in Southeastern Brazil. Papeis Avulsos de Zoologia (Sao Paulo) 52:333-340.

Cavender-Bares, J., K. H. Kozak, P. V. A. Fine, and S. W. Kembel. 2009. The merging of community ecology and phylogenetic biology. Ecology Letters 12:693-715.

Cianciaruso, M. V., I. A. Silva, and M. A. Batalha. 2009. Diversidade filogenética e funcional: novas abordagens para a ecologia de comunidades. Biota Neotropica 9:93-103.

CONAB. 2013. Acompanhamento da Safra Brasileira - Café Safra 2013. Companhia National de Abastecimento de Brasília.

Cornwell, W. K., D. W. Schwilk, and D. D. Ackerly. 2006. A trait-based test for habitat filtering: Convex hull volume. Ecology 87:1465-1471. 
De Coster, G., C. Banks-Leite, and J. P. Metzger. 2015. Atlantic forest bird communities provide different but not fewer functions after habitat loss. Proceedings of the Royal Society B-Biological Sciences 282.

del Hoyo, J., A. Elliott, J. Sargatal, D. A. Christie, and E. Juana. 2014. Handbook of the Birds of the World Alive. Linx Edicions, Barcelons.

Diaz, S. and M. Cabido. 2001. Vive la difference: plant functional diversity matters to ecosystem processes. Trends in Ecology \& Evolution 16:646-655.

Dornelas, M., N. J. Gotelli, B. McGill, H. Shimadzu, F. Moyes, C. Sievers, and A. E. Magurran. 2014. Assemblage Time Series Reveal Biodiversity Change but Not Systematic Loss. Science 344:296-299.

Driscoll, D. A., S. C. Banks, P. S. Barton, D. B. Lindenmayer, and A. L. Smith. 2013. Conceptual domain of the matrix in fragmented landscapes. Trends in Ecology \& Evolution 28:605-613.

Dunning, J. B., B. J. Danielson, and H. R. Pulliam. 1992. Ecological processes that affect populations in complex landscapes. Oikos 65:169-175.

Esquivel, M. A. and S. Peris. 2008. Influence of time of day, duration and number of counts in point count sampling of birds in an Atlantic forest of Paraguay. Ornitologia Neotropical 19:229-242.

Estavillo, C., R. Pardini, and P. L. Bernardo da Rocha. 2013. Forest Loss and the Biodiversity Threshold: An Evaluation Considering Species Habitat Requirements and the Use of Matrix Habitats. Plos One 8.

Ewers, R. M. and R. K. Didham. 2006. Confounding factors in the detection of species responses to habitat fragmentation. Biological Reviews 81:117-142.

Fahrig, L. 2002. Effect of habitat fragmentation on the extinction threshold: A synthesis. Ecological Applications 12:346-353.

Fahrig, L. 2013. Rethinking patch size and isolation effects: the habitat amount hypothesis. Journal of Biogeography 40:1649-1663.

Faith, D. P. 1992. Conservation evaluation and phylogenetic diversity. Biological Conservation 61:1-10.

Ficetola, G. F. and M. Denoel. 2009. Ecological thresholds: an assessment of methods to identify abrupt changes in species-habitat relationships. Ecography 32:1075-1084.

Foley, J. A., R. DeFries, G. P. Asner, C. Barford, G. Bonan, S. R. Carpenter, F. S. Chapin, M. T. Coe, G. C. Daily, H. K. Gibbs, J. H. Helkowski, T. Holloway, E. A. Howard, C. J. Kucharik, C. Monfreda, J. A. Patz, I. C. Prentice, N. Ramankutty, and P. K. Snyder. 2005. Global consequences of land use. Science 309:570-574. 
Fonseca, C. R. and G. Ganade. 2001. Species functional redundancy, random extinctions and the stability of ecosystems. Journal of Ecology 89:118-125.

Frishkoff, L. O., D. S. Karp, L. K. M'Gonigle, C. D. Mendenhall, J. Zook, C. Kremen, E. A. Hadly, and G. C. Daily. 2014. Loss of avian phylogenetic diversity in neotropical agricultural systems. Science 345:1343-1346.

Goncalves Rigueira, D. M., P. L. Bernardo da Rocha, and E. Mariano-Neto. 2013. Forest cover, extinction thresholds and time lags in woody plants (Myrtaceae) in the Brazilian Atlantic Forest: resources for conservation. Biodiversity and Conservation 22:3141-3163.

Hackett, S. J., R. T. Kimball, S. Reddy, R. C. K. Bowie, E. L. Braun, M. J. Braun, J. L. Chojnowski, W. A. Cox, K.-L. Han, J. Harshman, C. J. Huddleston, B. D. Marks, K. J. Miglia, W. S. Moore, F. H. Sheldon, D. W. Steadman, C. C. Witt, and T. Yuri. 2008. A phylogenomic study of birds reveals their evolutionary history. Science 320:1763-1768.

Hooper, D. U., F. S. Chapin, J. J. Ewel, A. Hector, P. Inchausti, S. Lavorel, J. H. Lawton, D. M. Lodge, M. Loreau, S. Naeem, B. Schmid, H. Setala, A. J. Symstad, J. Vandermeer, and D. A. Wardle. 2005. Effects of biodiversity on ecosystem functioning: A consensus of current knowledge. Ecological Monographs 75:3-35.

Horner-Devine, M. C. and B. J. M. Bohannan. 2006. Phylogenetic clustering and overdispersion in bacterial communities. Ecology 87:100-108.

Jarzyna, M. A. and W. Jetz. 2016. Detecting the multiple facets if biodiversity. Trends in Ecology \& Evolution:In press.

Jetz, W., G. H. Thomas, J. B. Joy, K. Hartmann, and A. O. Mooers. 2012. The global diversity of birds in space and time. Nature 491:444-448.

Jetz, W., G. H. Thomas, J. B. Joy, D. W. Redding, K. Hartmann, and A. O. Mooers. 2014. Global Distribution and Conservation of Evolutionary Distinctness in Birds. Current Biology 24:919-930.

Johnson, M. D., N. J. Levy, J. L. Kellermann, and D. E. Robinson. 2009. Effects of shade and bird exclusion on arthropods and leaf damage on coffee farms in Jamaica's Blue Mountains. Agroforestry Systems 76:139-148.

Jordano, P. 2016. Chasing ecological interactions. Plos Biology 14:1-4.

Jordano, P., P. M. Forget, J. E. Lambert, K. Bohning-Gaese, A. Traveset, and S. J. Wright. 2011. Frugivores and seed dispersal: mechanisms and consequences for biodiversity of a key ecological interaction. Biology Letters 7:321-323.

Kembel, S. W., P. D. Cowan, M. R. Helmus, W. K. Cornwell, H. Morlon, D. D. Ackerly, and C. O. Webb. 2010. Picante: $R$ tools for integrating phylogenies and ecology. Bioinformatics 26:1463-1464. 
Kupfer, J. A., G. P. Malanson, and S. B. Franklin. 2006. Not seeing the ocean for the islands: the mediating influence of matrix-based processes on forest fragmentation effects. Global Ecology and Biogeography 15:8-20.

Laliberté, E., P. Legendre, and B. Shipley. 2015. Measuring functional diversity (FD) from multiple traits, and other tools for functional ecology. Package 'FD':-28.

Lima, M. M. and E. Mariano-Neto. 2014. Extinction thresholds for Sapotaceae due to forest cover in Atlantic Forest landscapes. Forest Ecology and Management 312:260-270.

Lira, P. K., R. M. Ewers, C. Banks-Leite, R. Pardini, and J. P. Metzger. 2012. Evaluating the legacy of landscape history: extinction debt and species credit in bird and small mammal assemblages in the Brazilian Atlantic Forest. Journal of Applied Ecology 49:1325-1333.

Luck, G. W., A. Carter, and L. Smallbone. 2013. Changes in Bird Functional Diversity across Multiple Land Uses: Interpretations of Functional Redundancy Depend on Functional Group Identity. Plos One 8.

Lynch, J. F. 1995. Effects of point count duration, time-of-day, and aural stimuli on detectability of migratory and resident species in Quintana Roo, Mexico. Pages 1-6 in C. J. Ralph, J. R. Sauer, and S. Droege, editors. Monitoring bird population by point counts. USDA Forest Service General Technical Report PSW-GTR-149, Albany, CA.

Maas, B., Y. Clough, and T. Tscharntke. 2013. Bats and birds increase crop yield in tropical agroforestry landscapes. Ecology Letters 16:1480-1487.

Marini, M. A. 2010. Bird movement in a fragmented Atlantic Forest landscape. Studies on Neotropical Fauna and Environment 45:1-10.

Mason, N. W. H., K. MacGillivray, J. B. Steel, and J. B. Wilson. 2003. An index of functional diversity. Journal of Vegetation Science 14:571-578.

McKinney, M. L. 1997. Extinction vulnerability and selectivity: Combining ecological and paleontological views. Annual Review of Ecology and Systematics 28:495-516.

MEA. 2005. Millennium Ecosystem Assessment Synthesis, United Nations.

Mouchet, M., F. Guilhaumon, S. Villeger, N. W. H. Mason, J.-A. Tomasini, and D. Mouillot. 2008. Towards a consensus for calculating dendrogram-based functional diversity indices. Oikos 117:794-800.

Muggeo, V. M. R., D. C. Atkins, R. J. Gallop, and S. Dimidjian. 2014. Segmented mixed models with random changepoints: a maximum likelihood approach with application to treatment for depression study. Statistical Modelling 14:293-313.

Myers, N., R. A. Mittermeier, C. G. Mittermeier, G. A. B. da Fonseca, and J. Kent. 2000. Biodiversity hotspots for conservation priorities. Nature 403:853-858. 
Naeem, S., J. E. Duffy, and E. Zavaleta. 2012. The Functions of Biological Diversity in an Age of Extinction. Science 336:1401-1406.

Neuschulz, E. L., M. Brown, and N. Farwig. 2013. Frequent bird movements across a highly fragmented landscape: the role of species traits and forest matrix. Animal Conservation 16:170-179.

Ochoa-Quintero, J. M., T. A. Gardner, I. Rosa, S. F. de Barros Ferraz, and W. J. Sutherland. 2015. Thresholds of species loss in Amazonian deforestation frontier landscapes. Conservation Biology 29:440-451.

Oliveira, A. T. and M. A. L. Fontes. 2000. Patterns of floristic differentiation among Atlantic forests in southeastern Brazil and the influence of climate. Biotropica 32:793-810.

Oliver, T. H., N. J. B. Isaac, T. A. August, B. A. Woodcock, D. B. Roy, and J. M. Bullock. 2015. Declining resilience of ecosystem functions under biodiversity loss. Nature Communications 6.

Owens, I. P. F. and P. M. Bennett. 2000. Ecological basis of extinction risk in birds: Habitat loss versus human persecution and introduced predators. Proceedings of the National Academy of Sciences of the United States of America 97:12144-12148.

Owens, I. P. F., P. M. Bennett, and P. H. Harvey. 1999. Species richness among birds: body size, life history, sexual selection or ecology? Proceedings of the Royal Society BBiological Sciences 266:933-939.

Pagel, M. 1999. Inferring the historical patterns of biological evolution. Nature 401:877884.

Pardini, R., A. D. Bueno, T. A. Gardner, P. I. Prado, and J. P. Metzger. 2010. Beyond the Fragmentation Threshold Hypothesis: Regime Shifts in Biodiversity Across Fragmented Landscapes. Plos One 5.

Pasher, J., S. Mitchell, D. King, L. Fahrig, A. Smith, and K. Lindsay. 2013. Optimizing landscape selection for estimating relative effects of landscape variables on ecological responses. Landscape Ecology 28:371-383.

Pavoine, S. and M. B. Bonsall. 2011. Measuring biodiversity to explain community assembly: a unified approach. Biological Reviews 86:792-812.

Perovic, D. J., G. M. Gurr, A. Raman, and H. I. Nicol. 2010. Effect of landscape composition and arrangement on biological control agents in a simplified agricultural system: A cost-distance approach. Biological Control 52:263-270.

Petchey, 0. L. and K. J. Gaston. 2002. Functional diversity (FD), species richness and community composition. Ecology Letters 5:402-411.

Petchey, O. L. and K. J. Gaston. 2006. Functional diversity: back to basics and looking forward. Ecology Letters 9:741-758. 
Phalan, B., M. Onial, A. Balmford, and R. E. Green. 2011. Reconciling Food Production and Biodiversity Conservation: Land Sharing and Land Sparing Compared. Science 333:1289-1291.

Pompeu, P., M. Costa, and M. A. Fontes. 2009. Classificação e apresentação dos parâmetros climáticos de Poços de Caldas - MG. III Congresso Latino Americano de Ecologia, São Lourenço, Minas Gerais.

Prevedello J.A. \& Vieira M.V. (2010). Does the type of matrix matter? A quantitative review of the evidence. Biodivers Conserv, 19, 1205-1223.

Prevedello, J. A., N. Gotelli, and J. P. Metzger. In press. A stochastic model for landscape patterns of biodiversity. Ecological Monographs.

Purvis, A., P. M. Agapow, J. L. Gittleman, and G. M. Mace. 2000. Nonrandom extinction and the loss of evolutionary history. Science 288:328-330.

R Development Core Team. 2016. R: A Language and Environment for Statistical Computing. R Foundation for Statistical Computing, Vienna, Austria.

Renjifo, L. M. 2001. Effect of natural and anthropogenic landscape matrices on the abundance of subandean bird species. Ecological Applications 11:14-31.

Revell, L. J., L. J. Harmon, and D. C. Collar. 2008. Phylogenetic Signal, Evolutionary Process, and Rate. Systematic Biology 57:591-601.

Ribeiro, M. C., A. C. Martensen, J. P. Metzger, M. Tabarelli, F. Scarano, and M.-J. Fortin. 2011. The Brazilian Atlantic Forest: a shrinking biodiversity hotspot. Pages 405-434 in F. E. Zachos and J. C. Habel, editors. Biodiversity Hotspots: distribution and protection of conservation priority areas. Spring Verlag, Berlin.

Ribeiro, M. C., J. P. Metzger, A. C. Martensen, F. J. Ponzoni, and M. M. Hirota. 2009. The Brazilian Atlantic Forest: How much is left, and how is the remaining forest distributed? Implications for conservation. Biological Conservation 142:11411153.

Richmond, S., E. Jenkins, A. Couturier, and M. Cadman. 2015. Thresholds in forest bird richness in response to three types of forest cover in Ontario, Canada. Landscape Ecology 30:1273-1290.

Ricketts, T. H. 2001. The matrix matters: Effective isolation in fragmented landscapes. American Naturalist 158:87-99.

Ricotta, C. 2005. A note on functional diversity measures. Basic and Applied Ecology 6:479-486.

Ruffell, J., C. Mick, and R. K. Didham. 2016. The matrix matters, but how should we manage it? Estimating the amount of high-quality matrix required to maintain biodiversity in fragmented landscapes. Ecography 39:001-008. 
Saunders, D. A., R. J. Hobbs, and C. R. Margules. 1991. Biological consequences of ecosystem fragmentation - a review. Conservation Biology 5:18-32.

Saura, S., O. Bodin, and M. J. Fortin. 2014. Stepping stones are crucial for species' longdistance dispersal and range expansion through habitat networks. Journal of Applied Ecology 51:171-182.

Sekercioglu, C. H., D. G. Wenny, and C. J. Whelan. 2016. Why birds matter: avian ecological function and ecosystem services. The University of Chicago Press, Chicago, London.

Sick, H. 1997. Ornitologia Brasileira. Nova Fronteira, Rio de Janeiro.

Swenson, N. G. 2014. Functional and Phylogenetic Ecology in R. Springer, New York.

Thompson, P. L., T. J. Davies, and A. Gonzalez. 2015. Ecosystem Functions across Trophic Levels Are Linked to Functional and Phylogenetic Diversity. Plos One 10.

Tilman, D. 2001. Functional diversity. Pages 109-120 in S. A. Levin, editor. Encyclopedia of Biodiversity. Academic Press, San Diego.

Tscharntke, T., R. Bommarco, Y. Clough, T. O. Crist, D. Kleijn, T. A. Rand, J. M. Tylianakis, S. van Nouhuys, and S. Vidal. 2007. Conservation biological control and enemy diversity on a landscape scale. Biological Control 43:294-309.

Tubelis, D. P., D. B. Lindenmayer, and A. Cowling. 2007. Bird populations in native forest patches in south-eastern Australia: the roles of patch width, matrix type (age) and matrix use. Landscape Ecology 22:1045-1058.

Tucker, C. M., M. W. Cadotte, S. B. Carvalho, T. J. Davies, S. Ferrier, S. A. Fritz, R. Grenyer, M. R. Helmus, L. S. Jin, A. O. Mooers, S. Pavoine, O. Purschke, D. W. Redding, D. F. Rosauer, M. Winter, and F. Mazel. 2016. A guide to phylogenetic metrics for conservation, community ecology and macroecology. Biological Reviews.

Uezu, A., D. D. Beyer, and J. P. Metzger. 2008. Can agroforest woodlots work as stepping stones for birds in the Atlantic Forest region? . Biodiversity and Conservation 17:1907-1922.

UNICAMP, C. 2016. Clima dos municipios paulistas. Avaiable at: http://www.cpa.unicamp.br/outras-informacoes/clima-dos-municipiospaulistas.html. Access in October 28th 2016.

Villeger, S., N. W. H. Mason, and D. Mouillot. 2008. New multidimensional functional diversity indices for a multifaceted framework in functional ecology. Ecology 89:2290-2301.

Webb, C. 0. 2000. Exploring the phylogenetic structure of ecological communities: An example for rain forest trees. American Naturalist 156:145-155.

Webb, C. O., J. B. Losos, and A. A. Agrawal. 2006. Integrating phylogenies into community ecology. Ecology 87:S1-S2. 
Whelan, C. J., D. G. Wenny, and R. J. Marquis. 2008. Ecosystem services provided by birds. Year in Ecology and Conservation Biology 2008 1134:25-60. 


\section{Supplementary material}

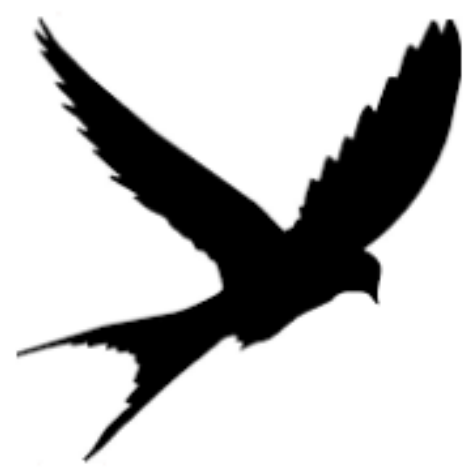




\section{Supplementary Material 1 (SOM1) - Functional traits selection}

Trait selection was based on features related to food type, intensity of resources use (body size), and species' reproductive output (i.e. nest type, clutch size; Table 1). These traits are related to both the role performed by birds in ecosystems and species ability to persist and breed in disturbed environments.

Food acquisition: we focused only on diet as trait related to resource use. Diet is related to how birds affect ecosystem function. Differences in diet specialization can provide information on niche width, bird morphology, energetic requirements (Remsen and Robinson 1990), and species function (for instance, seed dispersal, pollination, and insect predation). We assigned six diet categories: insectivorous, frugivorous, nectarivorous, granivorous, herbivorous, and carnivorous (details in Table 2). In addition, for functional traits related to diet, we performed a ranking of use as (De Coster et al. 2015) based on specialized literature (Sick 1997, del Hoyo et al. 2014).

Body size: Body size determines a host of species traits (Owens and Bennett 2000, Woodward et al. 2005). Larger species are often considered more vulnerable to extinction because they have naturally low population densities, slow growth rates, high energetic requirements, and might suffer from anthropogenic overexploitation (Cardillo et al. 2005). Because many life-history traits are correlated with body size, this variation can have potentially profound effects across multiple scales of biological organization, from individual to ecosystem functioning. Measuring body size is an easy way to collapse co-varying traits over a single dimension, with no need to observe these traits directly (Woodward et al. 2005). Species body mass information (weight) was compiled following Ramirez et al. (2008).

Reproductive output: reproductive potential of birds has profound effects upon the patterns of distribution and population abundance in environments (Beissinger 2000). Populations with high reproductive output and rapid population turnover may be able to respond rapidly to environmental changes and exploit new resource opportunities (Owens et al. 1999, Owens and Bennett 2000). On the other 
hand, populations with lower reproductive output and slower population turnover rates may be especially stable in suitable biotopes but are relatively sensitive to environmental changes.

1. Clutch size: it is the major component of natality rates and is relatively easy to measure (Skutch 1985). We assigned values of minimum and maximum number of eggs per clutch recorded for each species (Sick 1997, del Hoyo et al. 2014). Although it is assumed that there is a strong relationship between body size and clutch size (larges species producing smaller clutch sizes), in a recent global analysis, this assumption was only weakly confirmed (Jetz et al. 2008). Another factor influencing clutch size around world is nest type: cavity nesters (which are naturally exposed to lower rates of nest predation) tend to have smaller clutch sizes than open nesters, and species with half-open nests are in between. Clutch size also varies according to diet (i.e. granivores and omnivore laying larger clutches than frugivores and nectarivores; Jetz et al. 2008).

2. Nest type: One of the main factors impacting bird populations in fragmented landscapes is nest predation due the increase on predators and brood parasitism rates (Cavitt and Martin 2002, Tewksbury et al. 2006). Mortality rates are generally greater among field- and marshnesting passerines than among tree-nesting species, especially those nesting in cavities (Sibly et al. 2012). We assigned our species to four nest categories: closed, cavity, semi-open, and open (See Table 2 for major details). In addition, the lack of suitable nesting habitat in disturbed environments can have a strong effect on the reproductive success of certain bird species such as those from Picidae and Psittacidae families, which require old or dead trees to build their nests in (Sick 1997). 
Table 1. Functional traits selected to calculate functional diversity of bird assemblages. For each trait, the different possible measurements (levels) are listed, along with a description.

\begin{tabular}{lll}
\hline Trait & Levels & Description \\
\hline Body size & Body mass & body mass in grams \\
\hline Clutch size & Mean number of eggs & minimum and maximum \\
\hline & Closed & globular or cylindrical nest with entrance \\
& Cavities & nests built inside wood or soil cavities \\
& Semi-open & nests as a shallow or deep cup \\
Nest type & Open & exposed layer of leaves or sticks \\
\hline \multirow{3}{*}{ Diet } & Frugivorous & fruits, berries, fleshy seeds \\
& Insectivorous & insects, arthropods, caterpillars \\
& Granivorous & seeds, maize, nuts, spores \\
& Nectarivorous & nectar \\
& Carnivorous & vertebrate animals, fledglings, eggs, reptiles \\
& Herbivorous & flowers, leaves \\
\hline
\end{tabular}

Table 2. Ranking of intensity of use of diet traits to include in Functional Diversity calculation.

\begin{tabular}{cl}
\hline Ranking & Common words to describe use \\
\hline 0 & Nothing \\
1 & Also, at times, less commonly, less frequently, occasionally, once, only infrequently, \\
& possibly, probably, rarely, readily, regularly, relatively frequently, single records of, \\
& small amount, some, sometimes, supplemented by \\
2 & Also considerable, also important, also many, also much, also wide variety of, as well \\
& as, just as frequently, often \\
& Great majority, mainly, mostly, particularly, usually
\end{tabular}

*For those species using all resources without preference, was designated $\mathbf{2}$ for each component

\section{Literature cited}

Beissinger, S. R. 2000. Ecological mechanisms of extinction. Proceedings of the National Academy of Sciences of the United States of America 97:11688-11689.

Cardillo, M., G. M. Mace, K. E. Jones, J. Bielby, O. R. P. Bininda-Emonds, W. Sechrest, C. D. L. Orme, and A. Purvis. 2005. Multiple causes of high extinction risk in large mammal species. Science 309:1239-1241.

Cavitt, J. F. and T. E. Martin. 2002. Effects of forest fragmentation on brood parasitism and nest predation in eastern and western landscapes. Studies in Avian Biology:73-80. 
De Coster, G., C. Banks-Leite, and J. P. Metzger. 2015. Atlantic forest bird communities provide different but not fewer functions after habitat loss. Proceedings of the Royal Society B-Biological Sciences 282.

del Hoyo, J., A. Elliott, J. Sargatal, D. A. Christie, and E. Juana. 2014. Handbook of the Birds of the World Alive. Linx Edicions, Barcelons.

Jetz, W., C. H. Sekercioglu, and K. Boehning-Gaese. 2008. The Worldwide Variation in Avian Clutch Size across Species and Space. Plos Biology 6:2650-2657.

Owens, I. P. F. and P. M. Bennett. 2000. Ecological basis of extinction risk in birds: Habitat loss versus human persecution and introduced predators. Proceedings of the National Academy of Sciences of the United States of America 97:12144-12148.

Owens, I. P. F., P. M. Bennett, and P. H. Harvey. 1999. Species richness among birds: body size, life history, sexual selection or ecology? Proceedings of the Royal Society BBiological Sciences 266:933-939.

Ramirez, L., J. A. F. Diniz-Filho, and B. A. Hawkins. 2008. Partitioning phylogenetic and adaptive components of the geographical body-size pattern of New World birds. Global Ecology and Biogeography 17:100-110.

Remsen, J. V. J. and S. K. Robinson. 1990. A classification scheme for foraging behavior of birds in terrestrial habitats. Morrison, M. L., Et Al. (Ed.). Studies in Avian Biology, No. 13. Avian Foraging: Theory, Methodology, and Applications; International Symposium, Asilomar, California, USA, December 18-19, 1988. X+515p. Cooper Ornithological Society: Los Angeles, California, USA. Illus. Paper:144-160.

Sibly, R. M., C. C. Witt, N. A. Wright, C. Venditti, W. Jetz, and J. H. Brown. 2012. Energetics, lifestyle, and reproduction in birds. Proceedings of the National Academy of Sciences of the United States of America 109:10937-10941.

Sick, H. 1997. Ornitologia Brasileira. Nova Fronteira, Rio de Janeiro.

Skutch, A. F. 1985. Clutch size, nesting success, and predation on nests of Neotropical birds, reviewed. Ornithological Monographs:575-594.

Tewksbury, J. J., L. Garner, S. Garner, J. D. Lloyd, V. Saab, and T. E. Martin. 2006. Tests of landscape influence: Nest predation and brood parasitism in fragmented ecosystems. Ecology 87:759-768.

Woodward, G., B. Ebenman, M. Emmerson, J. M. Montoya, J. M. Olesen, A. Valido, and P. H. Warren. 2005. Body size in ecological networks. Trends in Ecology \& Evolution 20:402-409. 
Table S1. Forest-dependent species recorded in the study system. We are given both scientific and common name and if it was recorded in-patches embedded in pasture or in coffee matrices. We also demonstrate functional traits used to measure functional diversity. Body size (in grams), clutch size (mean clutch size - minimum and maximum), net type (open, closed, semi-open, cavity), and diet: I (insectivorous), F (frugivorous), G (granivorous), N (nectarivorous), C (carnivorous), H (herbivorous).

\begin{tabular}{|c|c|c|c|c|c|c|c|c|c|c|c|c|c|}
\hline Scientific name & Common name & Pasture & Coffee & $\begin{array}{l}\text { Body } \\
\text { size }\end{array}$ & $\begin{array}{l}\text { Eggs } \\
\text { (Min) }\end{array}$ & $\begin{array}{l}\text { Eggs } \\
\text { (Max) }\end{array}$ & Nest & $\mathbf{I}$ & $\mathbf{F}$ & G & $\mathbf{N}$ & C & $\mathbf{H}$ \\
\hline Accipiter striatus & Sharp-shinned Hawk & $\mathrm{X}$ & & 174 & 3 & 5 & open & 1 & 0 & 0 & 0 & 3 & 0 \\
\hline Anabazenops fuscus & White-collared Foliage-gleaner & $\mathrm{X}$ & $\mathrm{X}$ & 39 & 2 & 3 & open & 3 & 0 & 0 & 0 & 0 & 0 \\
\hline Arremon flavirostris & Saffron-billed Sparrow & & $\mathrm{X}$ & 28.5 & 3 & 3 & closed & 3 & 0 & 1 & 0 & 0 & 0 \\
\hline Arremon semitorquatus & Half-collared Sparrow & $\mathrm{X}$ & & 24.8 & 1 & 1 & closed & 3 & 0 & 1 & 0 & 0 & 0 \\
\hline Attila phoenicurus & Rufous-tailed Attila & $\mathrm{X}$ & & 34.5 & 3 & 4 & cavity & 3 & 1 & 0 & 0 & 0 & 0 \\
\hline Attila rufus & Grey-hooded Attila & $\mathrm{X}$ & & 43.4 & 3 & 4 & cavity & 3 & 1 & 0 & 0 & 0 & 0 \\
\hline Automolus leucophthalmus & White-eyed Foliage gleaner & $\mathrm{X}$ & $\mathrm{X}$ & 35.5 & 3 & 4 & cavity & 3 & 0 & 0 & 0 & 0 & 0 \\
\hline Baryphthengus rufucapillus & Rufous-capped Motmot & $\mathrm{X}$ & $\mathrm{X}$ & 175 & 2 & 3 & cavity & 3 & 1 & 0 & 0 & 3 & 0 \\
\hline Basileuterus culicivorus & Golden-crowned Warbler & $\mathrm{X}$ & $\mathrm{X}$ & 10.3 & 2 & 4 & closed & 3 & 1 & 0 & 0 & 0 & 0 \\
\hline Basileuterus flaveolus & Flavescent Warbler & & $\mathrm{X}$ & 13 & 3 & 3 & closed & 3 & 0 & 0 & 0 & 0 & 0 \\
\hline Basileuterus leucoblepharus & White-browed Warbler & $\mathrm{X}$ & $\mathrm{X}$ & 16.3 & 3 & 4 & closed & 3 & 0 & 0 & 0 & 0 & 0 \\
\hline Batara cinerea & Giant Antshrike & $\mathrm{X}$ & & 149 & 2 & 3 & open & 3 & 0 & 0 & 0 & 1 & 0 \\
\hline Cacicus chrysopterus & Golden-winged Cacique & $\mathrm{X}$ & $\mathrm{X}$ & 32.8 & 2 & 4 & closed & 3 & 1 & 0 & 1 & 3 & 0 \\
\hline Campephilus robustus & Robust Woodpecker & & $\mathrm{X}$ & 200 & 2 & 3 & cavity & 3 & 1 & 0 & 0 & 0 & 0 \\
\hline Carpornis cucullata & Hooded Barryeater & $\mathrm{X}$ & & 75.7 & 1 & 1 & open & 1 & 3 & 0 & 0 & 0 & 0 \\
\hline Celeus flavescens & Blond-crested Woodpecker & $\mathrm{X}$ & $\mathrm{X}$ & 150 & 2 & 4 & cavity & 3 & 1 & 0 & 0 & 0 & 0 \\
\hline Chamaeza campanisona & Short-tailed Antthrush & & $\mathrm{X}$ & 91.1 & 2 & 3 & cavity & 3 & 3 & 0 & 0 & 0 & 0 \\
\hline
\end{tabular}




\begin{tabular}{|c|c|c|c|c|c|c|c|c|c|c|c|c|c|}
\hline Chamaeza meruloides & Cryptic Antthrush & $\mathrm{X}$ & $\mathrm{X}$ & 70.9 & 2 & 2 & cavity & 3 & 0 & 0 & 0 & $\mathrm{c}$ & $\mathrm{c}$ \\
\hline Chiroxiphia caudata & Blue Manakin & $\mathrm{X}$ & $\mathrm{X}$ & 25.6 & 2 & 2 & semi & 2 & 3 & 0 & 0 & c & c \\
\hline Cissopis leverianus & Magpie Tanager & $\mathrm{X}$ & & 71 & 2 & 2 & semi & 1 & 3 & 0 & 0 & $\mathrm{c}$ & c \\
\hline Cnemotriccus fuscatus & Fuscous Flycather & $\mathrm{X}$ & $\mathrm{X}$ & 11.9 & 3 & 3 & semi & 3 & 0 & 0 & 0 & c & c \\
\hline Conirostrum speciosum & Chestnut-vented Conebill & $\mathrm{X}$ & $\mathrm{X}$ & 8.4 & 3 & 3 & semi & 3 & 0 & 0 & 3 & 4 & c \\
\hline Conopophaga lineata & Rufous Gnateater & $\mathrm{X}$ & $\mathrm{X}$ & 22.1 & 2 & 2 & semi & 3 & 1 & 0 & 0 & 4 & c \\
\hline Corythopis delalandi & Southern Antpipit & $\mathrm{X}$ & $\mathrm{X}$ & 14.9 & 2 & 3 & closed & 3 & 0 & 0 & 0 & 1 & c \\
\hline Cranioleuca pallida & Pallid Spinetail & $\mathrm{X}$ & $\mathrm{X}$ & 11.5 & 2 & 3 & closed & 3 & 0 & 0 & 0 & 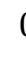 & $c$ \\
\hline Crypturellus obsoletus & Brown Tinamou & $\mathrm{X}$ & $\mathrm{X}$ & 482 & 4 & 5 & open & 3 & 0 & 3 & 0 & 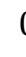 & $c$ \\
\hline Dendrocolaptes platyrostris & Planalto Woodpcreeper & $\mathrm{X}$ & $\mathrm{X}$ & 61.9 & 3 & 4 & cavity & 3 & 0 & 0 & 0 & 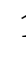 & 1 \\
\hline Dromoccoccys pavoninus & Pavonine Cucko & $\mathrm{X}$ & & 54 & 1 & 2 & open & 3 & 0 & 0 & 0 & 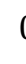 & 0 \\
\hline Drymophia rubricollis & Bertoni's Antbird & $\mathrm{X}$ & $\mathrm{X}$ & 21.4 & 2 & 2 & semi & 3 & 0 & 0 & 0 & 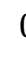 & c \\
\hline Drymophila ferruginea & Ferrugineous Antbird & $\mathrm{X}$ & $\mathrm{X}$ & 10.2 & 2 & 2 & semi & 3 & 0 & 0 & 0 & ( & $\mathrm{c}$ \\
\hline Drymophila malura & Dusky-tailed Antbird & $\mathrm{X}$ & $\mathrm{X}$ & 12.2 & 2 & 2 & semi & 3 & 0 & 0 & 0 & 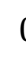 & ( \\
\hline Drymophila ochropyga & Ochre-rumped Antbird & $\mathrm{X}$ & $\mathrm{X}$ & 16.3 & 2 & 2 & semi & 3 & 0 & 0 & 0 & ( & c \\
\hline Drymophila squamata & Scaled Antbird & $\mathrm{X}$ & & 10.8 & 2 & 2 & semi & 3 & 0 & 0 & 0 & ( & $c$ \\
\hline Dysithamnus mentalis & Plain Antvireo & $\mathrm{X}$ & $\mathrm{X}$ & 14 & 2 & 2 & semi & 3 & 1 & 0 & 0 & ( & $c$ \\
\hline Euphonia chalybea & Green-chinned Euphonia & $\mathrm{X}$ & & 19 & 3 & 3 & closed & 1 & 3 & 0 & 0 & 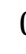 & ( \\
\hline Euphonia pectoralis & Chestnut-bellied Euphonia & $\mathrm{X}$ & & 14.4 & 3 & 3 & closed & 1 & 3 & 0 & 1 & ( & 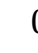 \\
\hline Geotrygon montana & Ruddy Quail-dove & $\mathrm{X}$ & & 135 & 1 & 2 & open & 1 & 3 & 3 & $c$ & 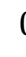 & ( \\
\hline Geotrygon violacea & Violaceous Quail-dove & $\mathrm{X}$ & & 150 & 2 & 2 & open & 1 & 3 & 3 & $c$ & ( & ( \\
\hline Grallaria varia & Variegated Antpitta & $\mathrm{X}$ & $\mathrm{X}$ & 121.5 & 2 & 2 & semi & 3 & 0 & 0 & 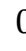 & ( & ( \\
\hline Habia rubica & Red-crowed Ant-tanager & $\mathrm{X}$ & & 35.2 & 1 & 4 & semi & 3 & 1 & 0 & $c$ & & ( \\
\hline Herpsilochmus longirostris & Large-billed Antwren & & $\mathrm{X}$ & 10.3 & 2 & 2 & semi & 3 & 0 & 0 & c & ( & ( \\
\hline
\end{tabular}




\begin{tabular}{|c|c|c|c|c|c|c|c|c|c|c|c|c|}
\hline Herpsilochmus rufimarginatus & Rufous-winged Antwren & $\mathrm{X}$ & $\mathrm{X}$ & 10.4 & 2 & 2 & semi & 3 & 1 & 0 & 0 & 0 \\
\hline Hylophilus poicilotis & Rufous-crownd Greenlet & $\mathrm{X}$ & $\mathrm{X}$ & 10 & 2 & 3 & semi & 3 & 1 & 0 & 0 & 0 \\
\hline Hypoedaleus guttatus & Spot-backed Antshrike & $\mathrm{X}$ & $\mathrm{X}$ & 46 & 2 & 2 & semi & 3 & 0 & 0 & 0 & 0 \\
\hline Lathrotriccus euleri & Euler's Flycatcher & $\mathrm{X}$ & $\mathrm{X}$ & 11 & 2 & 3 & semi & 3 & 0 & 0 & 0 & 0 \\
\hline Lepidocolaptes squamatus & Scaled Woodcreeper & $\mathrm{X}$ & $\mathrm{X}$ & 27 & 2 & 2 & cavity & 3 & 0 & 0 & 0 & 0 \\
\hline Leptopogon amaurocephalus & Sepia-capped Flycatcher & $\mathrm{X}$ & $\mathrm{X}$ & 10.7 & 2 & 2 & closed & 3 & 1 & 0 & 0 & 0 \\
\hline Leptotila rufaxilla & Grey-fronted Dove & $\mathrm{X}$ & $\mathrm{X}$ & 155 & 1 & 2 & open & 1 & 1 & 3 & 0 & 0 \\
\hline Lochmias nematura & Sharp-tailed Streamcreeper & $\mathrm{X}$ & $\mathrm{X}$ & 23 & 2 & 2 & closed & 3 & 0 & 0 & 0 & 0 \\
\hline Mackenziaena leachii & Large-tailed Antshrike & $\mathrm{X}$ & $\mathrm{X}$ & 67.8 & 2 & 2 & semi & 3 & 0 & 0 & 0 & 1 \\
\hline Mackenziaena severa & Tufted Antshrike & & $\mathrm{X}$ & 51.3 & 2 & 2 & semi & 3 & 0 & 0 & 0 & 1 \\
\hline Malacoptila striata & Greater Crescent-chested Puffbird & $\mathrm{X}$ & & 44.1 & 2 & 3 & cavity & 3 & 0 & 0 & 0 & 1 \\
\hline Micrastur ruficapillus & Barred Forest-falcon & & $\mathrm{X}$ & 193.5 & 2 & 3 & cavity & 3 & 0 & 0 & 0 & 3 \\
\hline Micrastur semitorquatus & Collared Forest-falcon & & $\mathrm{X}$ & 643 & 2 & 3 & cavity & 0 & 0 & 0 & 0 & 1 \\
\hline Mionectes rufiventris & Grey-hooded Flycatcher & $\mathrm{X}$ & $\mathrm{X}$ & 13.3 & 3 & 3 & closed & 3 & 3 & 0 & 0 & 0 \\
\hline Myiopagis caniceps & Grey Elaenia & $\mathrm{X}$ & $\mathrm{X}$ & 10.3 & 2 & 2 & semi & 3 & 1 & 0 & 0 & 0 \\
\hline Myiornis auricularis & Eared-Pygmy-tyrant & $\mathrm{X}$ & $\mathrm{X}$ & 5.3 & 2 & 3 & closed & 3 & 0 & 0 & 0 & 0 \\
\hline Myrmeciza squamosa & Squamate Antbird & $\mathrm{X}$ & & 18.5 & 2 & 2 & semi & 3 & 0 & 0 & 0 & 0 \\
\hline Odontophorus capueira & Spot-winged Wood-quail & & $\mathrm{X}$ & 396 & 3 & 5 & cavity & 1 & 3 & 3 & 0 & 0 \\
\hline Pachyramphus castaneus & Chestnut-crowned Becard & $\mathrm{X}$ & $\mathrm{X}$ & 17.3 & 2 & 4 & closed & 3 & 1 & 0 & 0 & 0 \\
\hline Pachyramphus validus & Plain Becard & $\mathrm{X}$ & & 28.8 & 4 & 4 & closed & 3 & 0 & 0 & 0 & 0 \\
\hline Pachyramphus viridis & Green-backed Becard & $\mathrm{X}$ & $\mathrm{X}$ & 21 & 2 & 4 & closed & 3 & 0 & 0 & 0 & 0 \\
\hline Penelope obscura & Dusky-legged Guan & $\mathrm{X}$ & $\mathrm{X}$ & 960 & 2 & 3 & semi & 0 & 3 & 1 & 0 & 0 \\
\hline Philydor rufum & Buff-fronted Foliage-gleaner & $\mathrm{X}$ & $\mathrm{X}$ & 32.5 & 2 & 3 & cavity & 3 & 0 & 0 & 0 & 0 \\
\hline Phyllomyias fasciatus & Planalto Tyrannulet & $\mathrm{X}$ & $\mathrm{X}$ & 10.5 & 2 & 2 & semi & 3 & 1 & 0 & 0 & 0 \\
\hline
\end{tabular}




\begin{tabular}{|c|c|c|c|c|c|c|c|c|c|c|c|c|}
\hline Phylloscartes ventralis & Mottle-cheeked Tyrannulet & $\mathrm{X}$ & $\mathrm{X}$ & 8.1 & 3 & 3 & closed & 3 & 0 & 0 & 0 & 0 \\
\hline Platyrinchus mystaceus & White-throated Spadebill & $\mathrm{X}$ & $\mathrm{X}$ & 10.2 & 2 & 2 & semi & 3 & 0 & 0 & 0 & 0 \\
\hline Poecilotriccus plumbeiceps & Ochre-faced Tody-flycatcher & $\mathrm{X}$ & $\mathrm{X}$ & 7.4 & 2 & 3 & closed & 3 & 0 & 0 & 0 & 0 \\
\hline Pogonotriccus eximius & Southern Bristle-tyrant & $\mathrm{X}$ & & 6.8 & 3 & 3 & closed & 3 & 0 & 0 & 0 & 0 \\
\hline Psilorhamphus guttatus & Spotted Bamboowren & $\mathrm{X}$ & & 22.5 & 2 & 2 & open & 3 & 0 & 0 & 0 & 0 \\
\hline Pteroglossus bailloni & Saffron Toucanet & $\mathrm{X}$ & & 139 & 2 & 3 & cavity & 0 & 3 & 0 & 0 & 1 \\
\hline Pyriglena leucoptera & White-shouldered Fire-eye & $\mathrm{X}$ & $\mathrm{X}$ & 28.8 & 2 & 2 & closed & 3 & 0 & 0 & 0 & 0 \\
\hline Pyroderus scutatus & Red-ruffed Fruitcrow & $\mathrm{X}$ & $\mathrm{X}$ & 372.5 & 1 & 1 & semi & 1 & 3 & 0 & 0 & 0 \\
\hline Pyrrhocoma ruficeps & Chestnut-headed Tanager & $\mathrm{X}$ & $\mathrm{X}$ & 15 & 2 & 3 & semi & 3 & 0 & 0 & 0 & 0 \\
\hline Saltator fuliginosus & Black-throated Grosbeak & & $\mathrm{X}$ & 50.8 & 2 & 3 & semi & 1 & 1 & 0 & 0 & 0 \\
\hline Saltator maxillosus & Thick-billed Saltator & & $\mathrm{X}$ & 59.9 & 3 & 3 & semi & 0 & 3 & 3 & 0 & 0 \\
\hline Schiffornis virescens & Greenish Mourner & $\mathrm{X}$ & $\mathrm{X}$ & 24.8 & 2 & 2 & semi & 3 & 1 & 0 & 0 & 0 \\
\hline Sclerurus scansor & Rufous-breasted Leaftosser & $\mathrm{X}$ & $\mathrm{X}$ & 37.4 & 2 & 3 & cavity & 3 & 0 & 0 & 0 & 0 \\
\hline Sirystes sibilator & Sirystes & $\mathrm{X}$ & $\mathrm{X}$ & 32 & 2 & 4 & cavity & 3 & 1 & 0 & 0 & 0 \\
\hline Sittasomus griseicapillus & Olivaceous Woodcreeper & $\mathrm{X}$ & $\mathrm{X}$ & 13.5 & 3 & 3 & cavity & 3 & 1 & 0 & 0 & 0 \\
\hline Sporophila frontalis & Buffy-fronted Seedater & $\mathrm{X}$ & & 14.3 & 2 & 3 & semi & 1 & 0 & 3 & 0 & 0 \\
\hline Synallaxis cinerascens & Grey-bellied Spinetail & $\mathrm{X}$ & $\mathrm{X}$ & 13.2 & 3 & 3 & closed & 3 & 0 & 0 & 0 & 0 \\
\hline Synallaxis ruficapilla & Rufous-capped Spinetail & $\mathrm{X}$ & $\mathrm{X}$ & 13.9 & 1 & 2 & closed & 3 & 0 & 0 & 0 & 0 \\
\hline Syndactyla rufosuperciliata & Buff-browed Foliage-gleaner & $\mathrm{X}$ & $\mathrm{X}$ & 27.7 & 2 & 4 & cavity & 3 & 0 & 0 & 0 & 0 \\
\hline Tangara cyanoventris & Gilt-edged Tanager & $\mathrm{X}$ & $\mathrm{X}$ & 16.5 & 2 & 2 & semi & 3 & 3 & 0 & 0 & 0 \\
\hline Tangara desmaresti & Brassy-breasted Tanager & $\mathrm{X}$ & & 19.8 & 2 & 2 & semi & 1 & 3 & 0 & 0 & 0 \\
\hline Terenura maculata & Streak-capped Antwren & $\mathrm{X}$ & & 6.5 & 2 & 2 & semi & 3 & 0 & 0 & 0 & 0 \\
\hline Thamnophilus caerulescens & Variable Antshrike & $\mathrm{X}$ & $\mathrm{X}$ & 21.4 & 2 & 3 & semi & 3 & 1 & 1 & 0 & 0 \\
\hline Tolmomyias sulphurescens & Yellow-olive Flycatcher & $\mathrm{X}$ & $\mathrm{X}$ & 14.8 & 2 & 3 & closed & 3 & 1 & 0 & 0 & 0 \\
\hline
\end{tabular}




\begin{tabular}{|c|c|c|c|c|c|c|c|c|c|c|}
\hline Trichothraupis melanops & Black-goggled Tanager & $\mathrm{X}$ & $\mathrm{X}$ & 24.3 & 3 & 3 & semi & 3 & 1 & \\
\hline Trogon rufus & Black-throated Trogon & $\mathrm{X}$ & & 55.5 & 2 & 2 & cavity & 3 & 1 & \\
\hline Trogon surrucura & Southern Surucua Trogon & $\mathrm{X}$ & $\mathrm{X}$ & 73.3 & 2 & 4 & cavity & J & 1 & \\
\hline Turdus albicollis & White-throated Thrush & $\mathrm{X}$ & $\mathrm{X}$ & 50 & 2 & 3 & semi & & 1 & \\
\hline Turdus flavipes & Yellow-legged Thrush & $\mathrm{X}$ & & 51.2 & 2 & 2 & semi & 1 & 3 & \\
\hline Xenops rutilans & Streaked Xenops & $\mathrm{X}$ & $\mathrm{X}$ & 12.8 & 2 & 3 & cavity & $J$ & 0 & \\
\hline Xyphorhynchus fuscus & Lesser Woodcreeper & $\mathrm{X}$ & $\mathrm{X}$ & 21.8 & 2 & 3 & cavity & 3 & 0 & \\
\hline
\end{tabular}


Table S2: Phylogenetic signal $(\lambda)$ measured for all functional traits used to calculate functional richness. It ranges from 0 to 1 , with values closer to 1 indicating higher phylogenetic signal. Log likelihood of estimates ( $\log L)$ and respective p-values are also shown.

\begin{tabular}{|c|c|c|c|}
\hline Functional trait & $\lambda$ & $\log L$ & $p$-value \\
\hline \multicolumn{4}{|l|}{ Low-permeability matrix } \\
\hline Body size & 1.006 & -461.9 & $<0.05^{*}$ \\
\hline Number of eggs (Min) & 0.56 & -75.67 & $>0.05$ \\
\hline Number of eggs (Max) & 0.82 & -101.12 & $<0.001^{*}$ \\
\hline Insectivorous & 0.78 & -88.15 & $<0.001^{*}$ \\
\hline Frugivorous & 0.97 & -111.65 & $<0.001^{*}$ \\
\hline Granivorous & 0.84 & -67.74 & $<0.001^{*}$ \\
\hline Nectarivorous & 0.02 & -32.65 & $>0.05$ \\
\hline Carnivorous & 1 & -66.73 & $<0.001^{*}$ \\
\hline Herbivorous & 0.87 & 27.33 & $<0.001^{*}$ \\
\hline Nest type & - & - & $<0.05^{*}$ \\
\hline \multicolumn{4}{|l|}{ Higher-permeability matrix } \\
\hline Body size & 1.004 & -415.53 & $<0.05^{*}$ \\
\hline Number of eggs (Min) & 0.42 & -51.92 & $>0.05$ \\
\hline Number of eggs (Max) & 0.82 & -76.71 & $<0.001^{*}$ \\
\hline Insectivorous & 0.76 & -72.45 & $<0.001^{*}$ \\
\hline Frugivorous & 0.67 & -93.85 & $<0.01^{*}$ \\
\hline Granivorous & 1.004 & -56.87 & $<0.01^{*}$ \\
\hline Nectarivorous & 0.0005 & -30.35 & $>0.05$ \\
\hline Carnivorous & 0.79 & -65.02 & $<0.05^{*}$ \\
\hline Herbivorous & 0.0006 & -36.1 & $>0.05$ \\
\hline Nest type & - & - & $<0.05^{*}$ \\
\hline
\end{tabular}


Table S3. Diversity indexes calculated for each sampling point in both types of matrix composition: P (pasture matrices), C (coffee matrices). Taxonomic diversity (TD), Functional diversity (FD), Phylogenetic diversity (PD), Phylogenetic diversity standard effect size $\left(\mathrm{PD}_{\text {ses }}\right)$.

\begin{tabular}{|c|c|c|c|c|c|c|c|}
\hline $\begin{array}{l}\text { Landscape } \\
\text { id }\end{array}$ & $\begin{array}{l}\text { Sample } \\
\text { Id }\end{array}$ & Matrix & $\begin{array}{l}\text { Forest } \\
\text { cover }\end{array}$ & TD & FD & PD & $\mathbf{P D}_{\text {ses }}$ \\
\hline P148 & 10 & $P$ & 9.3477 & 12 & 0.08758 & 423.8329 & -1.34942 \\
\hline P148 & 13 & $\mathrm{P}$ & 37.989 & 24 & 0.683532 & 791.2936 & -1.22117 \\
\hline P148 & 17 & $\mathrm{P}$ & 33.5624 & 26 & 0.391556 & 889.0463 & -0.84752 \\
\hline P148 & 18 & $\mathrm{P}$ & 73.9473 & 31 & 0.531186 & 1183.413 & 0.600347 \\
\hline P215 & 1 & $\mathrm{P}$ & 15.4375 & 12 & 0.758342 & 592.6722 & 0.386128 \\
\hline P215 & 4 & $\mathrm{P}$ & 47.0613 & 6 & 0.072987 & 297.1179 & -0.61391 \\
\hline P215 & 30 & $\mathrm{P}$ & 39.5115 & 19 & 0.724278 & 865.6926 & 1.074608 \\
\hline P215 & 35 & $\mathrm{P}$ & 37.8839 & 16 & 0.873541 & 711.3956 & 0.530675 \\
\hline P220 & 0 & $\mathrm{P}$ & 48.3349 & 30 & 0.784038 & 1086.072 & -0.10009 \\
\hline P220 & 7 & $\mathrm{P}$ & 15.0401 & 12 & 0.671803 & 511.8779 & -0.56818 \\
\hline P220 & 8 & $\mathrm{P}$ & 27.1422 & 17 & 0.760976 & 702.1461 & -0.29161 \\
\hline P220 & 19 & $P$ & 33.6789 & 27 & 0.813966 & 1058.016 & 0.499638 \\
\hline P263 & 0 & $\mathrm{P}$ & 7.6464 & 13 & 0.112096 & 521.2697 & -0.89694 \\
\hline P263 & 2 & $\mathrm{P}$ & 3.5751 & 5 & 0.07792 & 276.3014 & -0.15352 \\
\hline P263 & 5 & $\mathrm{P}$ & 7.4995 & 12 & 0.095568 & 449.2117 & -1.38865 \\
\hline P263 & 9 & $\mathrm{P}$ & 22.8289 & 18 & 0.703791 & 799.401 & 0.424935 \\
\hline P266 & 1 & $\mathrm{P}$ & 7.7327 & 15 & 0.495167 & 693.1343 & 0.296333 \\
\hline P266 & 12 & $\mathrm{P}$ & 12.7421 & 12 & 0.084 & 485.3885 & -0.94628 \\
\hline P266 & 22 & $\mathrm{P}$ & 53.569 & 31 & 0.506595 & 1059.34 & -0.55955 \\
\hline P266 & 28 & $\mathrm{P}$ & 37.6157 & 24 & 0.738019 & 891.3725 & -0.25953 \\
\hline P282 & 9 & $\mathrm{P}$ & 28.4045 & 13 & 0.116982 & 557.0635 & -0.43867 \\
\hline P282 & 13 & $\mathrm{P}$ & 18.3364 & 13 & 0.677352 & 580.623 & -0.19828 \\
\hline P282 & 19 & $\mathrm{P}$ & 19.6823 & 14 & 0.29908 & 579.7223 & -0.56964 \\
\hline P282 & 38 & $\mathrm{P}$ & 8.9832 & 5 & 0.077472 & 265.0476 & -0.40372 \\
\hline P291 & 1 & $\mathrm{P}$ & 43.4559 & 27 & 0.764604 & 1102.885 & 0.981935 \\
\hline P291 & 11 & $\mathrm{P}$ & 26.8632 & 34 & 0.815742 & 1326.859 & -1.14862 \\
\hline P291 & 17 & $\mathrm{P}$ & 61.8058 & 28 & 0.478021 & 1162.321 & 1.261586 \\
\hline P291 & 24 & $\mathrm{P}$ & 39.7145 & 31 & 0.799539 & 1194.742 & 0.4571 \\
\hline P317 & 0 & $\mathrm{P}$ & 48.4034 & 35 & 0.796249 & 1466.428 & 0.428682 \\
\hline P317 & 20 & $\mathrm{P}$ & 37.8239 & 33 & 0.840493 & 1153.48 & -0.17685 \\
\hline P317 & 22 & $\mathrm{P}$ & 63.4434 & 20 & 0.490288 & 734.822 & -0.55378 \\
\hline
\end{tabular}




\begin{tabular}{|c|c|c|c|c|c|c|c|}
\hline P317 & 24 & $\mathrm{P}$ & 64.767 & 29 & 0.888481 & 962.3952 & -1.02453 \\
\hline P329 & 0 & $\mathrm{P}$ & 14.1903 & 7 & 0.436073 & 444.6526 & 1.105888 \\
\hline P329 & 1 & $\mathrm{P}$ & 23.2632 & 14 & 0.123947 & 487.9376 & -1.25454 \\
\hline P329 & 7 & $\mathrm{P}$ & 17.9752 & 9 & 0.446554 & 461.7902 & 0.099962 \\
\hline P329 & 10 & $\mathrm{P}$ & 35.9127 & 10 & 0.099351 & 386.4565 & -1.33615 \\
\hline P333 & 2 & $\mathrm{P}$ & 22.4375 & 8 & 0.264949 & 421.2528 & 0.077191 \\
\hline P333 & 3 & $\mathrm{P}$ & 4.6893 & 4 & 0.050682 & 228.5567 & -0.18853 \\
\hline P333 & 4 & $\mathrm{P}$ & 10.0153 & 10 & 0.085224 & 358.1529 & -1.7795 \\
\hline P333 & 8 & $\mathrm{P}$ & 21.3022 & 13 & 0.70361 & 571.2279 & -0.32499 \\
\hline P335 & 1 & $\mathrm{P}$ & 28.8896 & 25 & 0.31166 & 806.6443 & -1.42766 \\
\hline P335 & $2 \mathrm{G}$ & $\mathrm{P}$ & 60.7647 & 27 & 0.662228 & 1042.367 & 0.32597 \\
\hline P335 & $2 \mathrm{P}$ & $\mathrm{P}$ & 9.1559 & 12 & 0.503169 & 553.6834 & -0.16131 \\
\hline P335 & 20 & $\mathrm{P}$ & 26.6026 & 22 & 0.459062 & 935.5569 & 0.826638 \\
\hline P359 & 2 & $\mathrm{P}$ & 12.0913 & 16 & 0.492966 & 715.8758 & 0.167607 \\
\hline P359 & 4 & $\mathrm{P}$ & 12.1113 & 17 & 0.513336 & 766.1737 & 0.731784 \\
\hline P359 & 13 & $\mathrm{P}$ & 25.2469 & 15 & 0.423237 & 694.4524 & 0.319859 \\
\hline P359 & 20 & $\mathrm{P}$ & 32.9214 & 24 & 0.790836 & 922.5029 & 0.026524 \\
\hline P399 & 0 & $\mathrm{P}$ & 43.8317 & 18 & 0.145859 & 664.066 & -1.02143 \\
\hline P399 & 9 & $\mathrm{P}$ & 20.1038 & 17 & 0.894842 & 730.2237 & -0.00766 \\
\hline P399 & 11 & $\mathrm{P}$ & 50.2616 & 10 & 0.411276 & 547.3801 & 0.785441 \\
\hline P399 & 18 & $\mathrm{P}$ & 20.206 & 14 & 0.744706 & 600.4185 & -0.35029 \\
\hline P02 & 0 & $\mathrm{C}$ & 57.51 & 24 & 0.729168 & 846.3368 & -0.16705 \\
\hline P02 & 1 & $\mathrm{C}$ & 43.33 & 24 & 0.183187 & 715.3724 & -1.55905 \\
\hline P02 & 2 & $\mathrm{C}$ & 51.41 & 21 & 0.384616 & 833.1117 & 0.519503 \\
\hline P02 & 3 & $\mathrm{C}$ & 51.59 & 32 & 0.408441 & 967.5554 & -0.76206 \\
\hline P09 & 0 & $\mathrm{C}$ & 16.76 & 20 & 0.117311 & 625.4373 & -1.45899 \\
\hline P09 & 1 & $\mathrm{C}$ & 14.03 & 15 & 0.119752 & 463.5406 & -1.74476 \\
\hline P09 & 2 & $\mathrm{C}$ & 19.02 & 16 & 0.33346 & 449.6709 & -2.20368 \\
\hline P09 & 3 & $\mathrm{C}$ & 12.65 & 17 & 0.123521 & 573.6657 & -1.16744 \\
\hline P10 & 0 & $\mathrm{C}$ & 26.33 & 25 & 0.718258 & 831.1365 & -0.64192 \\
\hline P10 & 1 & $\mathrm{C}$ & 21.69 & 25 & 0.754309 & 806.5829 & -0.90568 \\
\hline P10 & 2 & $\mathrm{C}$ & 28.62 & 37 & 0.776842 & 1061.041 & -1.31199 \\
\hline P10 & 3 & $\mathrm{C}$ & 44.39 & 24 & 0.733878 & 810.2877 & -0.58864 \\
\hline P11 & 0 & $\mathrm{C}$ & 51.8634 & 27 & 0.748132 & 890.4791 & -0.62033 \\
\hline P11 & 1 & $\mathrm{C}$ & 54.2145 & 29 & 0.421998 & 735.6826 & -2.68516 \\
\hline P11 & 2 & $\mathrm{C}$ & 33.3042 & 23 & 0.285159 & 660.2209 & -1.871 \\
\hline P11 & 3 & $\mathrm{C}$ & 7.33 & 13 & 0.599304 & 516.6151 & -0.49569 \\
\hline $\mathrm{P} 12$ & 0 & $\mathrm{C}$ & 35.95 & 24 & 0.637079 & 814.3311 & -0.5849 \\
\hline P12 & 1 & $\mathrm{C}$ & 35.63 & 15 & 0.111686 & 452.4793 & -1.91868 \\
\hline
\end{tabular}




\begin{tabular}{llllllll} 
P12 & 2 & C & 57.7797 & 22 & 0.278981 & 667.8609 & -1.57284 \\
P12 & 3 & C & 52.91 & 23 & 0.638526 & 814.9062 & -0.28909 \\
P19 & 0 & C & 37.5803 & 22 & 0.149392 & 554.0372 & -2.75587 \\
P19 & 1 & C & 72.82 & 30 & 0.573062 & 962.04 & -0.58318 \\
P19 & 2 & C & 50.0458 & 30 & 0.677276 & 1040.757 & 0.196698 \\
P19 & 3 & C & 62.23 & 29 & 0.498648 & 1077.807 & 0.819842 \\
P26 & 0 & C & 18.9986 & 25 & 0.355611 & 861.7666 & -0.40358 \\
P26 & 1 & C & 16.1737 & 34 & 0.385641 & 808.0214 & -3.18068 \\
P26 & 2 & C & 21.3872 & 28 & 0.73358 & 913.5376 & -0.60991 \\
P26 & 3 & C & 36.6065 & 36 & 0.59899 & 1144.407 & -0.2471 \\
P27 & 0 & C & 36.8156 & 30 & 0.643808 & 981.4384 & -0.43713 \\
P27 & 1 & C & 30.0334 & 28 & 0.68425 & 861.835 & -1.13973 \\
P27 & 2 & C & 40.8874 & 23 & 0.60696 & 820.3381 & -0.18831 \\
P27 & 3 & C & 43.6138 & 27 & 0.500844 & 743.176 & -2.02309 \\
P28 & 0 & C & 25.1072 & 40 & 0.737573 & 1056.336 & -2.20797 \\
P28 & 1 & C & 15.19 & 27 & 0.356413 & 726.7271 & -2.28816 \\
P28 & 2 & C & 34.7123 & 25 & 0.585223 & 954.2387 & 0.650307 \\
P28 & 3 & C & 40.1279 & 29 & 0.333075 & 925.3192 & -0.79667 \\
P30 & 0 & C & 26.21 & 21 & 0.592802 & 698.4994 & -0.60193 \\
P30 & 1 & C & 29.9278 & 22 & 0.198978 & 716.3047 & -1.01627 \\
P30 & 2 & C & 8.8915 & 12 & 0.088008 & 444.2675 & -0.9942 \\
P30 & 3 & C & 34.02 & 31 & 0.724812 & 913.3035 & -1.32133 \\
\hline
\end{tabular}




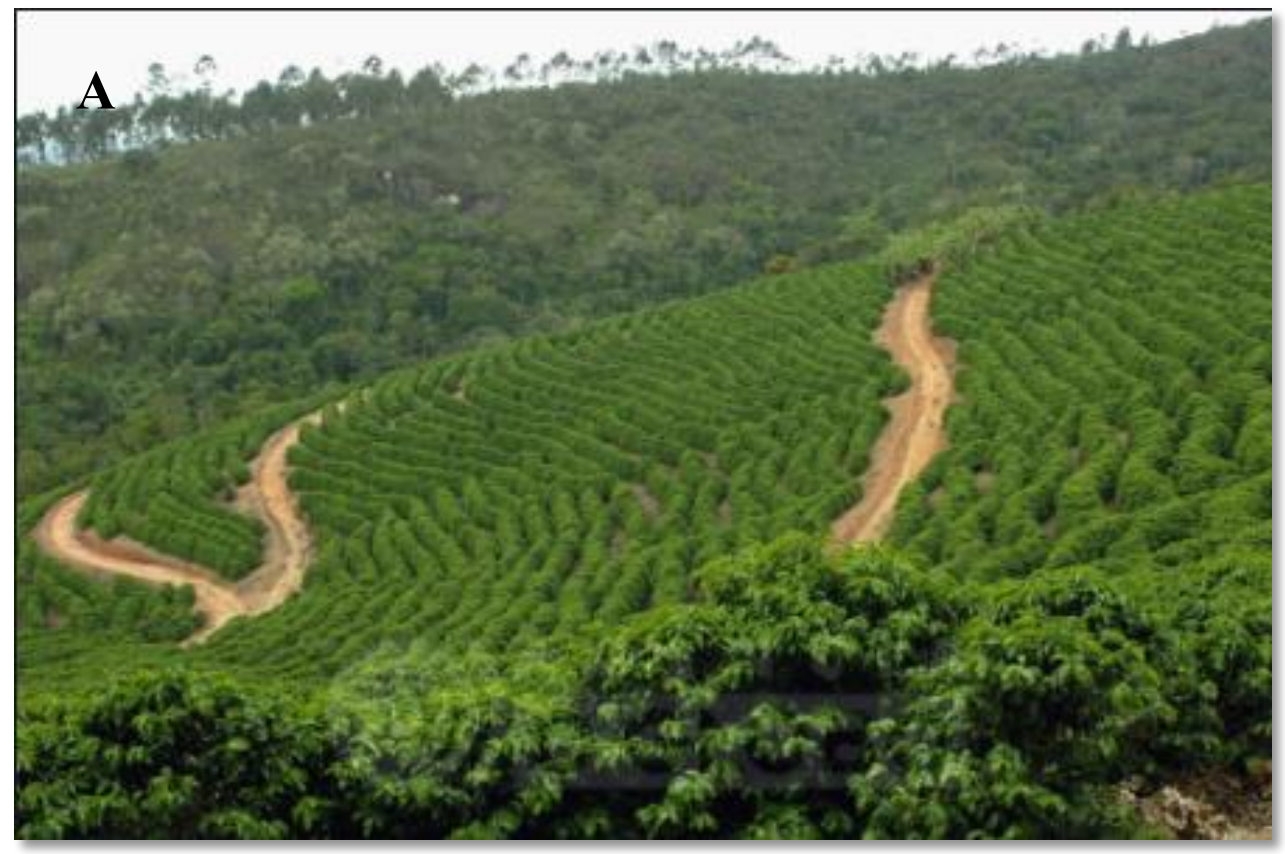

B

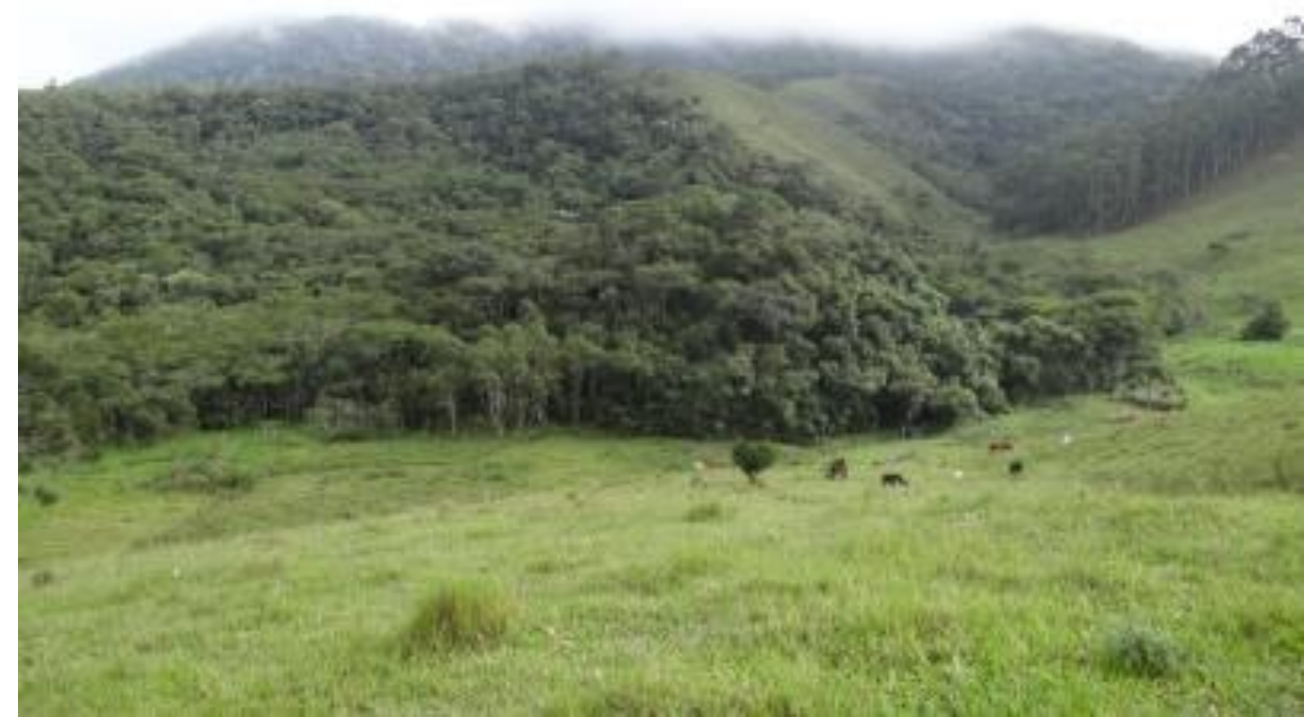

Figure S1. Illustration of matrix composition in studied areas. A: coffee matrix; B: pasture matrix. 

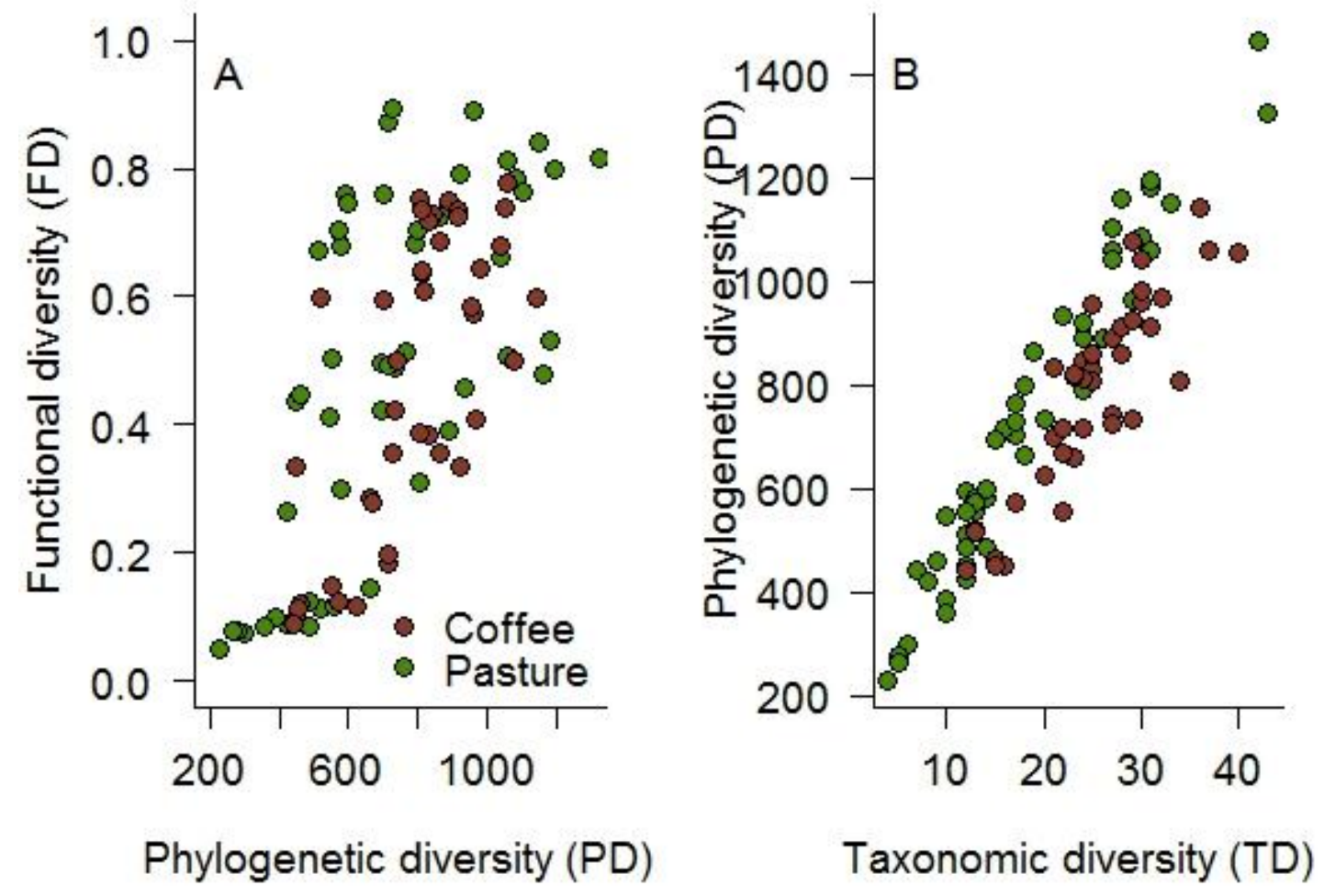

Figure S2. (A) Correlation between phylogenetic (PD) and functional diversity (FD) and between taxonomic (TD) and phylogenetic diversity (B) in both contexts of matrix permeability (pasture and coffee plantations). 

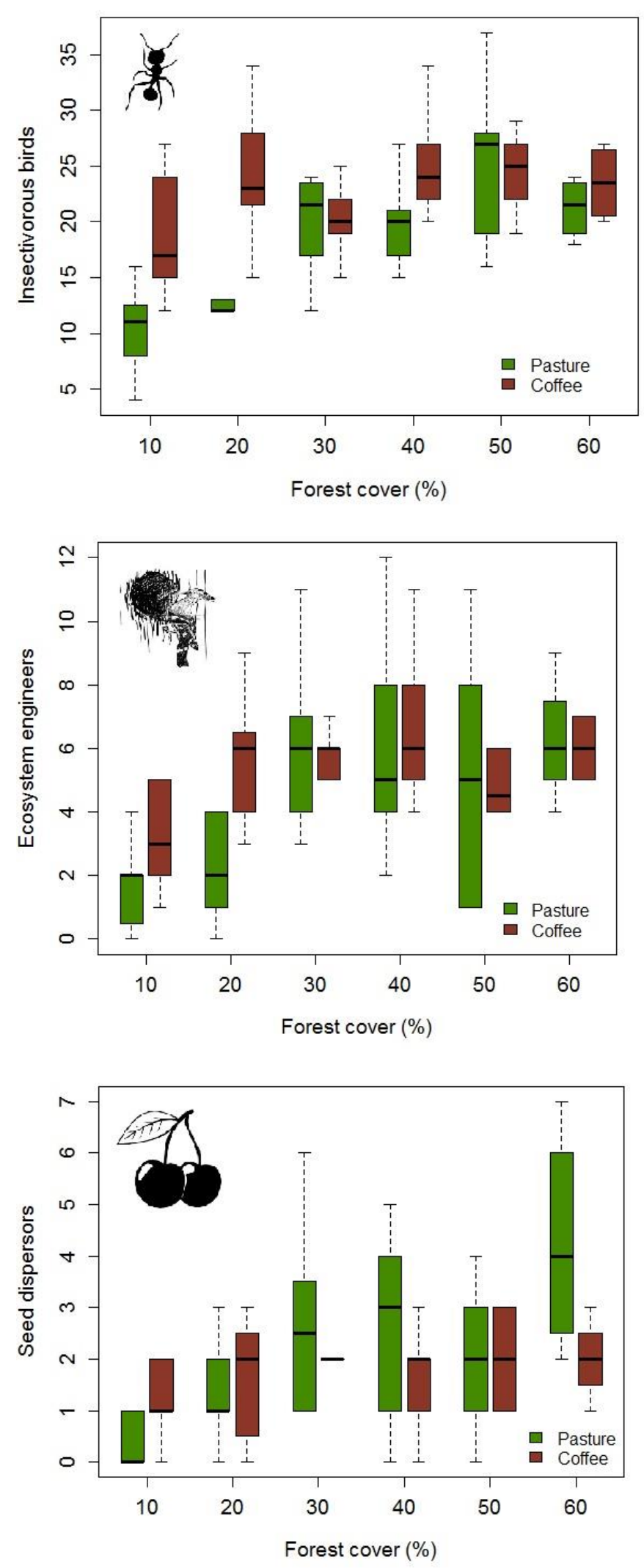

Figure S3: Loss of bird functions along the forest cover gradient. Avian insectivores, ecosystem engineers, and seed dispersers are shown. 


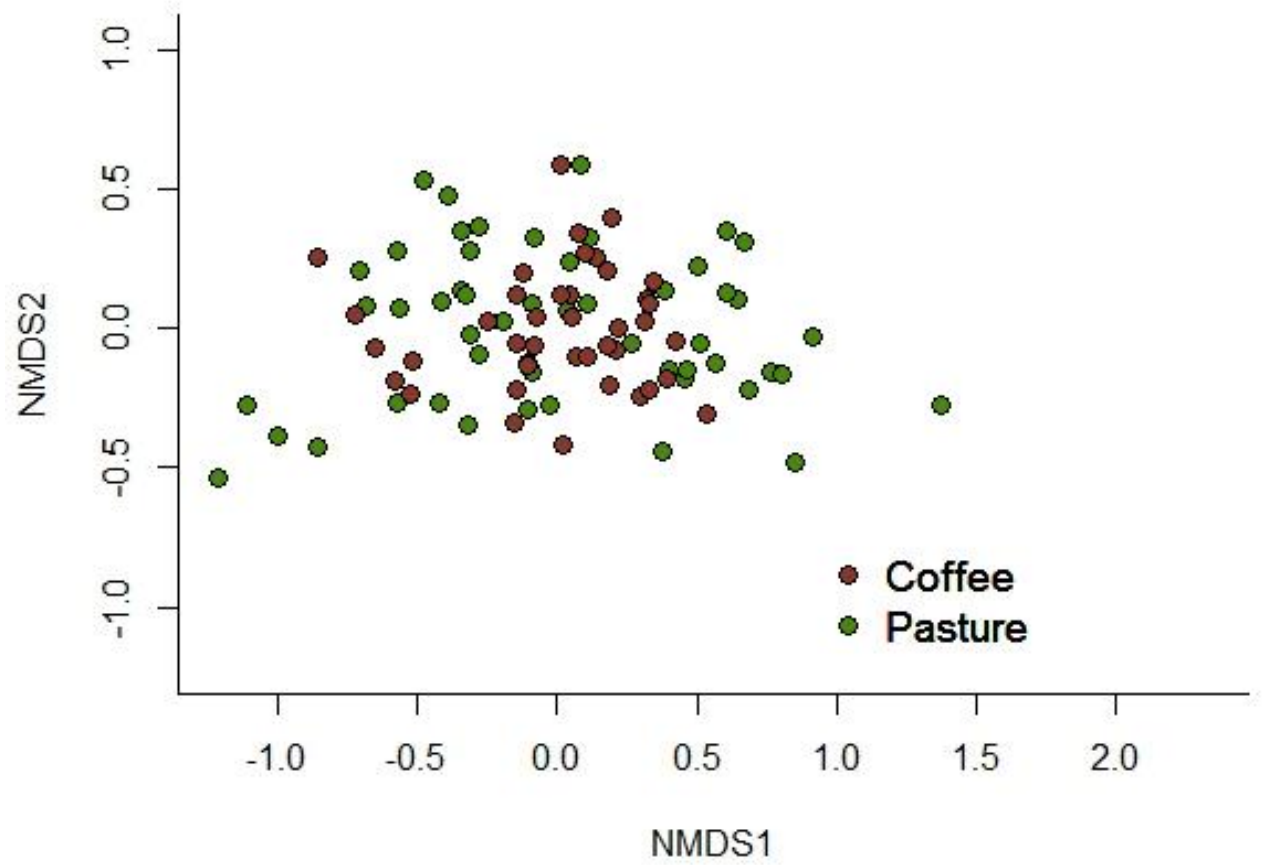

Figure S4. Bray-Curtis dissimilarity between bird assemblages in forest patches embedded in both coffee and pasture matrices. 


\section{Chapter 3}

\section{How does landscape structure modulate avian cross-habitat spillover?}

Andrea Larissa Boesing, Elizabeth Nichols, Jean Paul Metzger

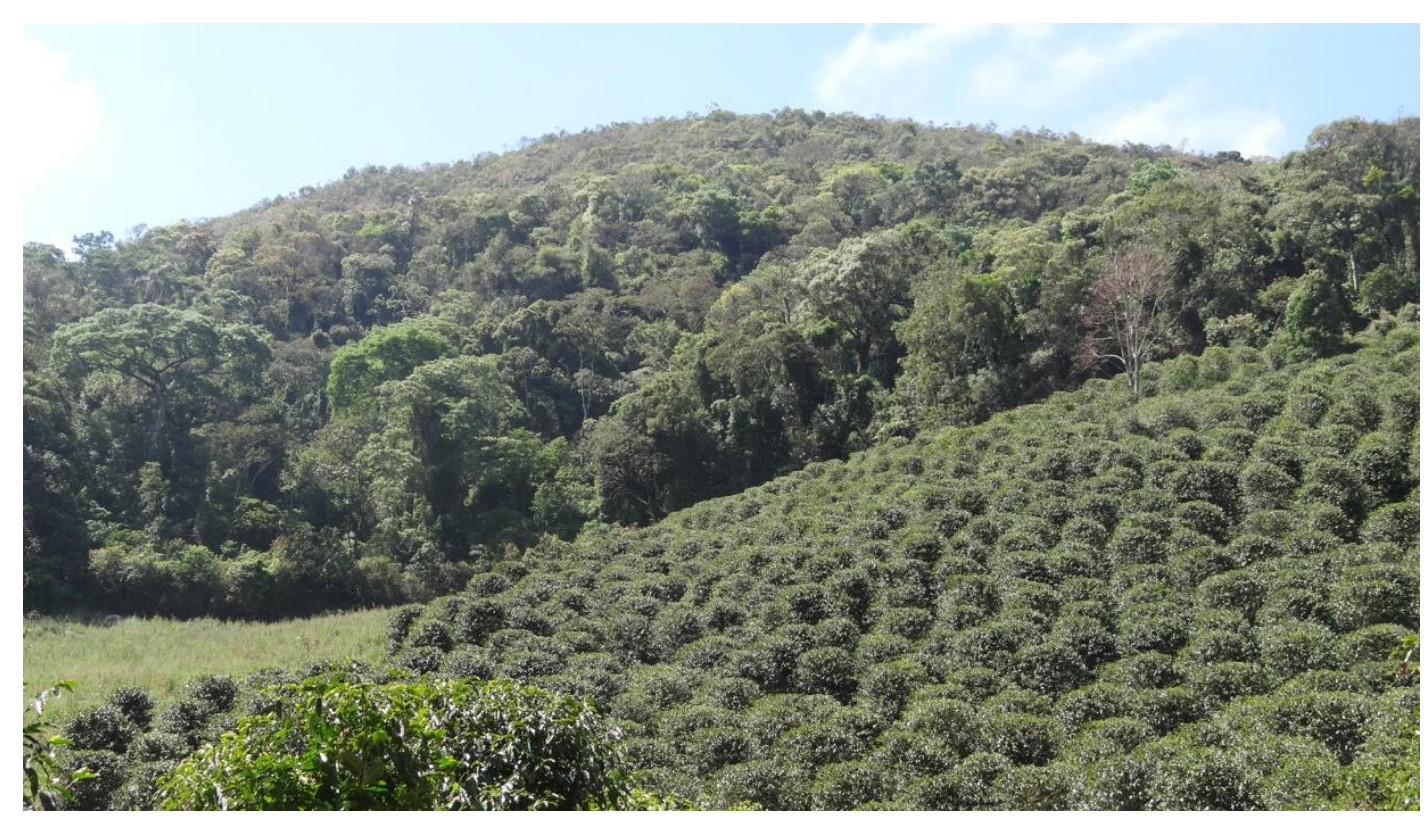




\section{Abstract}

Natural habitats adjacent to crop fields are often considered source habitats of species that provide beneficial regulating ecosystem services through cross-habitat spillover, such as pest control and pollination. Both matrix composition and landscape configuration should influence spillover by controlling organismal ability to disperse through landscapes, influencing species functional connectivity, and affecting the provision of additional or supplementary resources that impact organism survival. Using a well-replicated study design across 23 independent landscapes ( $2 \mathrm{~km}$ radius), we sampled avian communities in both forest patches and adjacent agricultural matrices across a landscape-level forest cover gradient (9-54\%) and in two contexts of matrix permeability: lower-permeability (cattle pastures, $\mathrm{N}=13$ ) and higher-permeability (sun coffee plantations; $\mathrm{N}=10$ ). We expected that spillover would be intensified in coffee matrices and at intermediated amounts of forest cover, as landscape-level edge density peaks at intermediate forest cover. We found that $24 \%$ of the forest-dependent species pool was capable of spilling over into coffee matrices, while spillover was nearly nonexistent in pasture matrices. The number of forest-dependent bird individuals spilling over into coffee matrices is intensified in landscapes with high edge density, however this effect was heightened in landscapes with low forest cover. This unexpected result may be due to higher resource competition at smaller native habitat amounts, compelling individuals to move to areas of lower density or because edge density increases functional connectivity and provides better access to different resources types. The few records of birds travelling among patches through pasture matrices occurred exclusively in highly forested landscapes. We present strong evidence that matrix permeability is a key factor facilitating species spillover into agricultural matrices, and that a combination of edge density and habitat amount is especially important facilitating species spilling over into matrices. These results should be considered in efforts to plan or manage sustainable agricultural landscapes.

Key-words: Agricultural systems; Dispersal; Edge density; Forest cover; Landscape complementation; Landscape supplementation; Matrix composition. 


\section{Introduction}

Cross-habitat spillover is defined as the exchange of materials or movement of organisms among different habitats, and encompasses both organismal dispersal and foraging that takes them from one distinct habitat type to another (Blitzer et al. 2012; Tscharntke et al. 2012). Cross-habitat spillover may have important impacts on ecosystem processes (McCoy et al. 2009), especially on food web dynamics through ecological coupling of consumers and resources (Holt 1996).

Cross-habitat spillover may occur in both directions, from native habitats to matrix (i.e. areas of non-habitat or less suitable habitat; Villard \& Metzger 2014), and from matrix to native habitats (Rand et al. 2006; Lucey \& Hill 2012; Frost et al. 2015; Schneider et al. 2016). In recent years, spillover from native habitat to matrix habitat has attracted particular scientific attention, as species that spill over into crop fields might provide beneficial regulating ecosystem services, such as pest control and crop pollination (Bianchi et al. 2006; Kremen et al. 2007). Spillover from native to agricultural patches has frequently been documented for native-habitat specialist pollinators (Ricketts et al. 2006; Livingston et al. 2013), invertebrates (Thies et al. 2005; Lucey \& Hill 2012), avian predators (Bianchi et al. 2006; Maas et al. 2015; Boesing et al. in review), and small mammals (Estavillo et al. 2013). Given that spillover may provide key ecological services in agricultural fields, understanding the role of landscape structure on spillover regulation is an important component of efforts to design and manage multifunctional agricultural landscapes.

Spillover can be considered a connectivity process, acting at edges between different habitats (Rand et al. 2006). As both connectivity and edge effects are affected by landscape structure (Taylor et al. 1993; Fahrig 2002), and particularly by the composition of the surrounding matrix, it is expected that both landscape structure and matrix composition should affect cross-habitat spillover (Blitzer et al. 2012). More habitat cover is associated with increased species richness and abundance inside habitat patches (Martensen et al. 2012) and decreased isolation among patches (Fahrig 2003), which should favor cross-habitat spillover both due to the higher density of organisms in "source" habitat patches (Brudvig et al. 2009) as well as lower isolation, which should favor movement among habitat patches (Baguette et al. 2012). In addition, lower isolation facilitates supplementation 
processes, defined as the capacity of the landscape to provide the same kind of resource in different neighboring patches in order to supplement the lack of sufficiently abundant resources in only one patch (Dunning et al. 1992). In this case, species needing a specific resource cannot be limited to one patch, and should thus move among several patches to obtain the necessary amount of resources (Villard \& Metzger 2014).

Spillover should also be intensified in more complex or heterogeneous mosaics, where contact between native habitat and matrix is more frequent. Increased areas of contact between matrix and native habitat can enhance functional connectivity among different habitats (Perovic et al. 2010) and may also increase the propensity of individuals to leave their source habitat. Following this reasoning, spillover should be particularly favored at intermediate amounts of forest cover, when edge density usually reaches its peak (Fahrig 2003; Villard \& Metzger 2014). However, spillover might be attenuated to some extent when edge contrasts between habitat and matrix reduce animal movement (Rand \& Louda 2006).

Finally, spillover might be a function of the permeability of the matrix surrounding habitat patches. Empirical evidence suggests that dung beetles (Collinge \& Palmer 2002), mammals (Estavillo et al. 2013), and birds (Boesing et al. In prep) are more likely to move into a low-contrast (high permeability) matrix (Gray et al. 2016). In addition to facilitating inter-patch movement of organisms, different kind of land uses in the matrix might provide additional or alternative foraging and nesting resources, contributing to landscape complementation processes, i.e. the capacity of a landscape to provide different kind of resources, usually located in different landscape units (Dunning et al. 1992). This means that not only a particular landscape composition, but also adequate spatial arrangement and heterogeneity are necessary in order to make the different types of resources functionally available (Villard \& Metzger 2014).

Birds are an especially interesting group of organisms to test ideas about how landscape structure influences cross-habitat spillover from native habitats into agricultural matrices. As vagile organisms, birds can easily move between habitat patches and might benefit from resources pulses, moving from patches in which resources are no longer sufficient to other areas where resources are 
available or even to establish new territories (Whelan et al. 2008). In addition, birds have a diverse range of functional traits, which allows them to use a variety of resources (Sekercioglu et al. 2016) and provide an associated diversity of ecosystem services (Whelan et al. 2008). While our understanding of the influence of landscape structure bird species composition inside native habitat patches (Banks-Leite et al. 2012; Martensen et al. 2012) and in different matrix types (Karp et al. 2013; Maas et al. 2015) is growing, how landscape structure and matrix composition influence avian-cross habitat spillover has not yet been rigorously tested.

We tested these ideas by relating three key aspects of landscape structure (native habitat cover, edge density, and matrix composition) to measures of aviancross-habitat spillover, using a well-replicated and landscape-level study design. We collected data across 23 independent landscapes, spanning a gradient of tropical forest cover (6-54\%), where forest patches were embedded in either lowpermeability matrix habitat (i.e. cattle pasture), or high-permeability matrix (i.e. sun coffee plantations). We tested three related hypotheses: (1) that highpermeability matrices are associated with higher avian cross-habitat spillover; (2) that avian-cross habitat spillover is intensified at intermediate amounts of native habitat cover; and (3) avian cross-habitat spillover is intensified in landscapes with higher edge density.

\section{Methods}

Study region: Field data were collected in the northeast São Paulo Atlantic Plateau and in the South Minas Gerais Mogiana region in southeastern Brazil (Fig. 1). The study region has a subtropical climate (UNICAMP 2016), with annual mean temperature varying from $11.3^{\circ} \mathrm{C}$ (minimum, in the colder season AprilSeptember) to $27.7^{\circ} \mathrm{C}$ (maximum, in the warmer season October-March), and annual rainfall varying between 1,350 and 2,000 $\mathrm{mm}$ (Pompeu et al. 2009). The relief is hilly to mountainous, with elevation between 700-1700 m.a.s.l (Oliveira \& Fontes 2000). The whole region was once covered by Atlantic Forest, a tropical forest domain with one of the highest rates of species diversity and endemism in the world (Myers et al. 2000; Brooks et al. 2002). However, after five centuries of human expansion (Joly et al. 2014), much of the region has been reduced to 
fragments in early to medium stages of succession (Lira et al. 2012), and more than $80 \%$ of forest remnants are smaller than 50 ha (Ribeiro et al. 2009).

Landscape selection: Field sites were located in 231,256 ha (2 km radius) landscapes varying between 6 and 54\% native forest cover (Fig. 1). All landscapes were constrained to be between 800 and 1,300 m.a.s.l on ferric red latosol or argisol soil, and to exclude major interstate highways and water reservoirs in order to control these potential confounding factors (Pasher et al. 2013). A minimum distance of $6 \mathrm{~km}$ between landscape centroids was maintained to guarantee spatial independence between landscapes. Land use and land cover in each $2 \mathrm{~km}$ focal landscape was mapped using high-resolution images (ArcGis 10.3 basemap imagery, DigitalGlobe satellites 2010-2011; scale of 1:5,000). Ten studied landscapes are located in a major traditional area for coffee production in Brazil, responsible for about one third of the whole Brazilian production (EMBRAPA 2016). The matrix in this region is composed mostly of sun coffee plantations, considered as a "high-permeability matrix" (Fig. S1A). The remaining 13 landscapes are situated in the Cantareira region, where the matrix is composed mostly of unmanaged cattle pastures (Fig. S1B), considered a "low-permeability matrix". The agricultural matrices within focal landscapes also contained other land use types (sugar cane, eucalyptus plantations, urban settlements), but in much smaller proportions than the main land use type.

Study sites and bird sampling: We selected four forest patches within each of the 23 focal landscapes ( $\mathrm{N}=92$ forest patches) using a stratified random proportional selection process based on the largest fragment size, using Sampling Design tool in ArcGIS 10.1. We calculated the percentage of total forest cover represented by the largest forest fragment in each landscape and allocated that proportion of sampling sites to that fragment. For instance, if the largest fragment contained $50 \%$ of the landscape forest cover, $50 \%$ of sampling sites $(\mathrm{N}=2)$ were located at this fragment, and 50\% were randomly distributed across the remaining forest fragments larger than 2.5 ha. In each one of the 92 selected forest patches (varying from 2.5 to 571.9 ha), we randomly selected a sampling site along the forest-matrix interface and placed a sampling point to bird counting $100 \mathrm{~m}$ inwards forest from 
the edge $(100.92 \pm 12.97 \mathrm{~m})$ and another sampling point $100 \mathrm{~m}$ from the edge in the adjacent matrix $(109.30 \pm 30.37 \mathrm{~m})$, creating a paired design with two sampling points per sampling site (Fig. 2). Each sampling site was spaced at minimum $800 \mathrm{~m}$ apart $(1,591 \pm 621 \mathrm{~m})$.
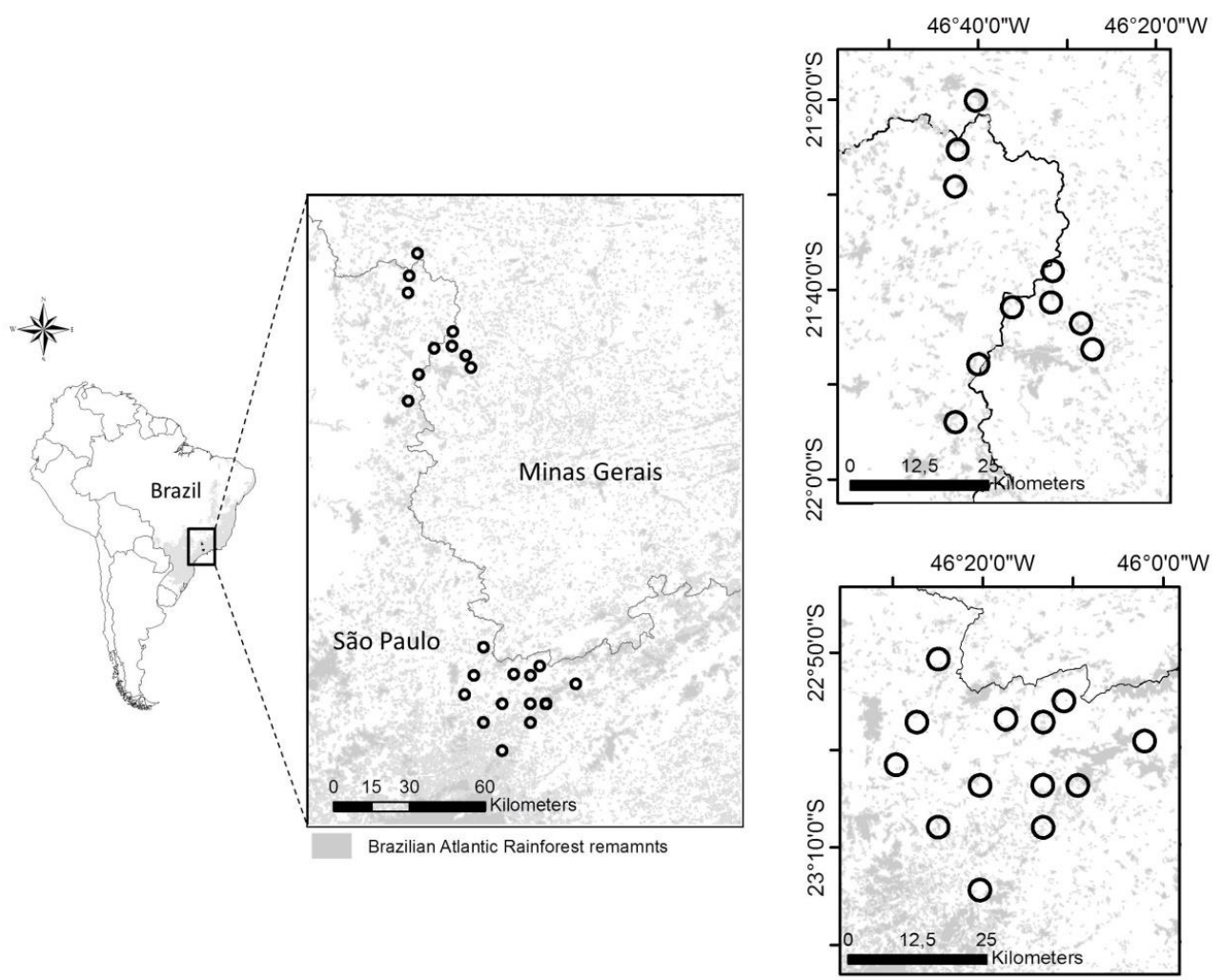

Figure 1. Study areas in the Brazilian Atlantic Forest domain between states of São Paulo and Minas Gerais. Ten 2-km radius landscapes within coffee matrices are shown in the top right-hand panel, and thirteen 2-km radius landscapes within pasture matrices are shown in the bottom righthand panel.

Birds were counted using $15 \mathrm{~min} 50 \mathrm{~m}$ fixed-radius point counts (Blondel et al. 1970; Bibby et al. 2002), the most recognized method for sampling birds in Neotropical regions (Blake 2007). This method consists of counting all birds detected visually or aurally within a given radius from a sampling point within a period of $15 \mathrm{~min}$. Species flying above the canopy or flying through the sample area were not recorded (Bibby et al. 2002). A total of 184 sampling points (92 inside forest patches; 92 in the adjacent matrix) were sampled, replicated four times within one year (between January-April and August-November 2014; $\mathrm{N}=736$ point counts). Studies using point counts in the Brazilian Atlantic Rainforest 
indicate that four replicates is enough to record 80 - $90 \%$ of bird species, including rare and inconspicuous species (Anjos 2003; Anjos et al. 2011). All point counts were performed within the periods that birds are more active: in the four hours after sunrise and the last hour before sunset (Lynch 1995; Esquivel \& Peris 2008). In addition, each point count was sampled in different times (early in the morning and end of the afternoon), giving the same chance of detection for all species. All point counts were performed by the same observer (A.L.B.).
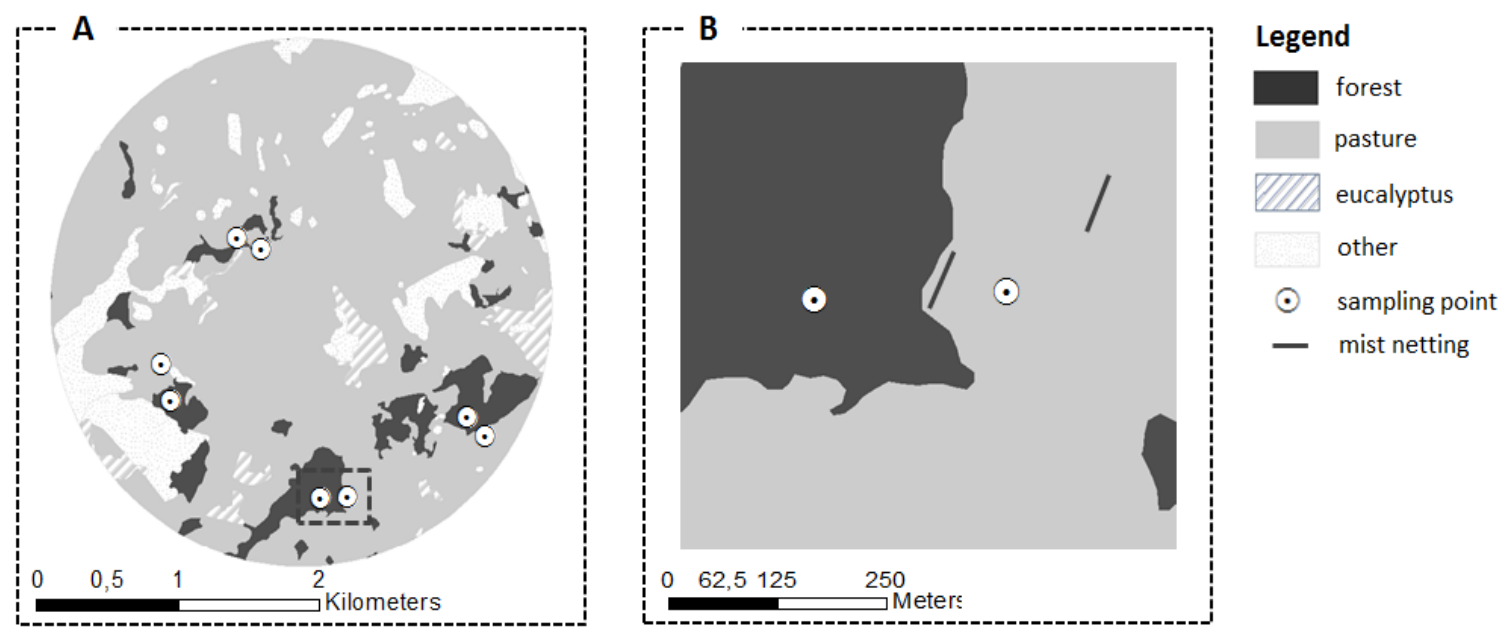

Figure 2. An example of sampling sites distribution in one of the study landscapes (low permeability matrix) with $30 \%$ forest cover. In each landscape we placed four sampling sites with paired sampling points (A). A closer view of one sampling site (B) showing the spatial arrangement of two sampling points used for bird point counts, and two lines of mist nets used for catching birds.

We complemented bird point counts by performing captures using mist nets in pasture matrices in three $2 \mathrm{~km}$ focal landscapes (10,30, and $50 \%$ of forest cover) in order to detect species potentially missed in point counts (Dunn \& Ralph 2004). We performed this additional sampling only in pasture matrices, as very few birds were detected using point counts in this matrix, and mist netting could potentially determine whether species were traveling through pasture matrices, even if they were not spending time there. Mist nets were placed in 3 of the 4 sampling site locations within each landscape (i.e. using the same forest-matrix interface as for point counts; Fig. 2). We placed a line of seven mist nets (12 m length, $3 \mathrm{~m}$ high, $29 \mathrm{~mm}$ mesh) parallel to the edge of the sampled forest patch ( $\sim 5$ $\mathrm{m}$ from the edge, outside the forest), and another line $\sim 150 \mathrm{~m}$ from the edge in the 
pasture matrix. A total of 18 mist net lines (6 lines per landscape; 3 at edges; 3 in the matrix) were monitored for a period of six hours in the morning for two consecutive days, totaling 12,096 net-hours per sampling site $(36,288$ net-hours per landscape). Permission for data collection was obtained from the Brazilian Institute of Environment and Renewable Natural Resources (IBAMA) under SISBIO number 46697-1.

Data analysis: We restricted all analyses to forest-dependent species (i.e. those species dependent of forest environments to breeding and survive; Sick 1997; del Hoyo et al. 2014). We defined 'spillover species' as those forest-dependent species that were recorded in both forest and the adjacent matrix in at least one sampling site. We quantified three measures of spillover, at both the community and species levels. First, we defined spillover abundance as the overall abundance of forestdependent species in the matrix in relation to the adjacent forest patch. Second, we defined spillover richness as the overall number of forest-dependent species in the matrix in relation to the adjacent forest patch. Third, for the most abundant spillover species, we defined an individual spillover abundance as the proportion of a given species' abundance in the matrix habitat in relation to its abundance in the adjacent forest patch.

To test our first hypothesis that high-permeability matrices are associated with increased spillover of forest-dependent birds, we used a paired t-test comparing spillover richness and abundance between matrices (coffee plantations and cattle pastures) using data from the paired point counts. In order to test the relationship between spillover and native habitat cover and edge-density (second and third hypothesis), we modeled spillover richness, spillover abundance, and individual spillover as a function of forest cover and edge density in a series of generalized linear mixed models with Binomial error distributions, and incorporating focal landscape identity as random factor. We used forest cover as the percentage of forest cover around each sampling site within a $800 \mathrm{~m}$ radius buffer and edge density (m/ha), given by the sum of the lengths (m) of all edge segments of forest-non-forest divided by the total landscape area (using $800 \mathrm{~m}$ radius buffer) and multiplied by 10,000 to convert to hectares. We used $800 \mathrm{~m}$ as our definition of landscape spatial scale, as a series of evidence suggests that 800 
$m$ adequately reflects forest-dependent species' response to landscape processes in the Brazilian Atlantic Forest (Boscolo \& Metzger 2009; Banks-Leite et al. 2011). For example, data on bird movement suggests that most movements are limited to under $400 \mathrm{~m}$, with a small portion up to $1000 \mathrm{~m}$ (Marini 2010). In addition, most species in the study region are Passeriformes, a group with relatively reduced dispersal ability and smaller territories (Lira et al. 2012). In total, we built five predictive models (including a null model), incorporating the individual, additive, and interactive effects of forest cover and edge density, then performed model selection (AICc), to identify the best predictive model, considering models with $\Delta$ AICc $\leq 2$ as equiprobable (Burnham \& Anderson 2002).

To assess the differences in pasture captures in mist nets according to the three levels of forest cover $(10 \%, 30 \%, 50 \%)$ we performed a one-way analysis of variance (ANOVA) using square root transformed spillover richness and abundance as a function of forest cover Homogeneity of variance was tested using the Barlett test.

All analyses were conducted in the $\mathrm{R}$ environment, version 3.3 .1 ( $R$ Development Core Team 2016), using the packages "bbmle" (Bolker 2016), "lme4" (Bates et al. 2016), and "car" (Fox et al. 2016).

\section{Results}

We found 71 forest-dependent species in forest patches embedded in coffee matrices and 85 species in forest patches in pasture matrices (Table S1). In coffee matrices, we recorded 17 species spilling over, corresponding to $24 \%$ of the forestdependent species pool. Over 83\% of all these individuals (113 individuals in total; Table 1) were represented by only six species. In contrast, we observed only five individuals from five different species spilling over into pasture matrices (Table 1). Both spillover richness $(\mathrm{t}=-10.72, \mathrm{df}=42.11, \mathrm{p}<0.001$; Fig. 3$)$ and abundance $(\mathrm{t}=$ -9.76, $\mathrm{df}=40.22, \mathrm{p}<0.001$; Fig. 3 ) were significantly higher in coffee matrices.

Mist netting data confirmed that forest-dependent species rarely move into pasture matrices, as no species were caught in the nets placed deep (e.g. $\leq 150 \mathrm{~m}$ ) within pastures. Of the 11 species and 28 individuals captured in mist nets at forest edges, around $60 \%$ of both species and individuals were caught in the mostforested landscapes (richness: $F_{1,7}=6.87, p=0.03$; abundance: $F_{1,7}=7.84 p=0.02$; 
Fig. SM2). The majority of individuals caught in more forested landscapes were recorded leaving (as opposed to entering) the forest $(n=12)$. As native habitat cover decreased, the number of captures also decreased substantially, to only four captures in intermediate forest cover (in either direction), and three catches of a single species (Golden-crowned Warbler) entering the forest in the landscape with the least forest cover (Fig. 4).
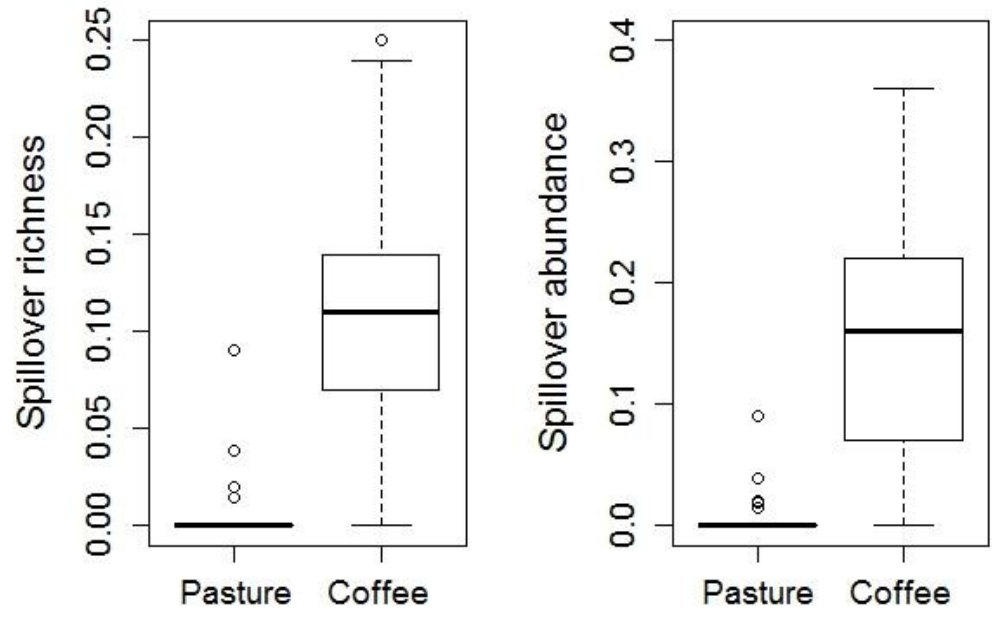

Figure 3. Boxplots of both spillover richness and abundance into coffee and pasture matrices. The median spillover richness was $0.11(\mathrm{IQR}=0.07-0.14)$ in coffee matrices and 0 in pasture matrices. Median spillover abundance was $0.16(\mathrm{IQR}=0.07-0.22)$ in coffee matrices and 0 in pasture matrices.

As bird occurrence in pasture matrices was practically non-existent (only five unique occurrences recorded in point counts), we tested our second and third hypotheses only in coffee matrices. There was no clear predictor of spillover richness into coffee matrices (Table 2). However, best predictive model of spillover abundance into coffee matrices was the interactive model of forest cover and edge density (Table 2; Fig. 5). Spillover abundance was intensified when edge density is higher, particularly when forest cover is low. There was no clear predictor of individual spillover abundance into coffee matrices for the six most abundant forest-dependent species (Table S2). 


\section{Discussion}

We found strong evidence that matrix composition plays a key role in facilitating avian cross-habitat spillover into agricultural matrices. About $24 \%$ of the forestdependent species pool could spill over into coffee matrices, while spillover was an exceptionally rare occurrence in pasture matrices, and occurred nearly exclusively in highly forested landscapes. Furthermore, we observed that edge density might positively affect spillover when matrix permeability is high, especially in lessforested landscapes. These findings highlight the importance of increasing the permeability of matrices surrounding native habitat patches in order to ensure species movement, and the importance of maintaining native habitat patches adjacent to crop fields to ensure the provision of ecosystem services.

Matrix permeability is a key factor influencing avian cross-habitat spillover, facilitating species movement into coffee matrices and acting as a barrier to spill over into pasture matrices. The structure of coffee plantations leads to a lesscontrasting edge with native patches, which favors bird movement through the matrix, especially for understory insectivorous birds that compose the totality of birds spilling over to these plantations (see Table 1). Edge effects might be less pronounced when the matrix is structurally similar to the original habitat (Renjifo 2001), allowing some species (or subset of species) to cross this edge (Renjifo 2001; Perfecto et al. 2004; Hernandez et al. 2013), which is perceived as a soft edge (Duelli et al. 1990; Gascon et al. 1999).

On the other hand, pasture matrices present a very contrasting edge, which should discourage the movement of birds from forest to pasture. In addition to this barrier effect associated with their physical structure (Ries et al. 2004), pasture habitats may be higher risk for predation attempts on forest-dependent species (Silva 2012). Translocation experiments using a forest-dependent species (Whiteshouldered Fire-eye Pyriglena leucoptera) demonstrated higher predation risk in pastures relative to eucalyptus or corn matrices, linked to high predator density (Silva 2012). Nearly all of the bird movement we recorded through pasture patches occurred in short gap-crossing events, in highly-forested landscapes. While this corroborates the findings of other studies that have found that spillover intensifies with forest cover (e.g. Estavillo et al. 2013; Gonzalez et al. 2016), more 
Table 1. Total abundance (number of individuals) of forest-dependent bird species spilling over into coffee matrices (using point counts*) and into pasture matrices (using both point counts* and mist nets**). Total abundance in-matrices and in-forest patches are given for both matrices. Diet: Ins (predominantly insectivorous), Fru (predominantly frugivorous); Foraging stratum: U (understory), M (midstory), C (canopy); Foraging behavior: Gle (Gleaning: gathering food items from a nearby substrate that can be reached without extension of legs or neck; no acrobatic movement involved); Pec (Pecking: driving the bill against the substrate to remove some of the exterior of the substrate); Pro (Probing: inserting the bill into cracks or holes in firm substrate or directly into softer substrates to capture hidden food); Han (Hanging: using legs and toes to suspend the body below the feet to reach food that cannot be reached from any other perched position); Lun (Lunging: those maneuvers in which food item is beyond the range of 'reach', but rapid leg movements rather than flight are used to approach and capture the prey); Fla (Flaking: brushing aside loose substrate with sideways, sweeping motions of the bill); Fly (Flycatching: attacking in a fluid movement without gliding, hovering or landing); Hov (Hovering: the bird hovers at the target substrate at the end of the sally); Sal (Sally-pouncing: landing briefly at the end of the flight to take food from a substrate). In-matrix (total abundance of forest-dependent species inside matrices), In-patch (total abundance of forest-dependent species in the adjacent forest patch), $\boldsymbol{B}$ (total abundance in the matrix in relation to the adjacent forest patch). Bird nomenclature follows del Hoyo et al. (2014).

\begin{tabular}{|c|c|c|c|c|c|c|c|c|c|c|c|c|}
\hline \multirow[b]{3}{*}{ Common name } & \multirow[b]{3}{*}{ Scientific name } & \multirow[b]{3}{*}{ Diet } & \multirow[b]{3}{*}{$\begin{array}{l}\text { Foraging } \\
\text { stratum }\end{array}$} & \multirow[b]{3}{*}{$\begin{array}{l}\text { Foraging } \\
\text { behavior }\end{array}$} & \multirow[b]{3}{*}{$\begin{array}{l}\text { Body } \\
\text { size } \\
\text { (grams) }\end{array}$} & \multicolumn{7}{|c|}{ Total abundance } \\
\hline & & & & & & \multicolumn{3}{|c|}{ 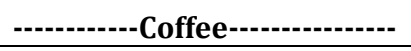 } & \multicolumn{4}{|c|}{ 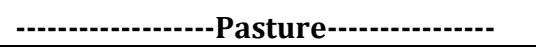 } \\
\hline & & & & & & $\begin{array}{l}\text { In- } \\
\text { matrix }\end{array}$ & $\begin{array}{l}\text { In- } \\
\text { Patch* }\end{array}$ & $B$ & $\begin{array}{l}\text { In- } \\
\text { matrix }\end{array}$ & $\begin{array}{l}\text { In- } \\
\text { patch* }\end{array}$ & $\boldsymbol{B}$ & $\begin{array}{l}\text { In- } \\
\text { matrix** }\end{array}$ \\
\hline $\begin{array}{l}\text { Golden-crowned } \\
\text { Warbler }\end{array}$ & Basileuterus culicivorus & Ins & $\mathrm{U} / \mathrm{M}$ & Gle/Fly/Pro & 10.3 & 21 & 252 & 0.083 & 1 & 326 & 0.003 & 7 \\
\hline $\begin{array}{l}\text { White-shouldered } \\
\text { Fire-eye }\end{array}$ & Pyriglena leucoptera & Ins & $\mathrm{U}$ & Gle/Sal/Lun & 28.8 & 19 & 126 & 0.151 & 0 & 56 & 0.000 & 0 \\
\hline Plain Antvireo & Dysithamnus mentalis & Ins & $\mathrm{U}$ & Gle/Hov/Sal & 14 & 17 & 166 & 0.102 & 1 & 163 & 0.006 & 0 \\
\hline Variable Antshrike & Thamnophilus caerulescens & Ins & $\mathrm{U}$ & Gle/Hov/Sal/Lun & 21.4 & 16 & 95 & 0.168 & 0 & 82 & 0.000 & 0 \\
\hline Flavescent Warbler & Basileuterus flaveolus & Ins & $\mathrm{U}$ & Gle/Lun/Fla & 13 & 13 & 62 & 0.210 & 0 & 0 & - & 0 \\
\hline $\begin{array}{l}\text { Ochre-faced Tody- } \\
\text { flycatcher }\end{array}$ & Poecilotriccus plumbeiceps & Ins & $\mathrm{U}$ & Hov/Sal & 7.4 & 8 & 79 & 0.101 & 0 & 25 & 0.000 & 0 \\
\hline $\begin{array}{l}\text { Rufous-crowned } \\
\text { Greenlet }\end{array}$ & Hylophilus poicilotis & Ins & $\mathrm{M} / \mathrm{C}$ & Gle/Han & 10 & 3 & 10 & 0.300 & 0 & 3 & 0.000 & 0 \\
\hline $\begin{array}{l}\text { Buff-browed } \\
\text { Foliage-gleaner }\end{array}$ & Syndactyla rufosuperciliata & Ins & $\mathrm{U}$ & Gle & 27.7 & 3 & 24 & 0.125 & 0 & 5 & 0.000 & 0 \\
\hline
\end{tabular}




\begin{tabular}{|c|c|c|c|c|c|c|c|c|c|c|c|c|}
\hline Rufous Gnateater & Conopophaga lineata & Ins & $\mathrm{U}$ & Gle/Fla & 22.1 & 2 & 98 & 0.020 & 0 & 106 & 0.000 & 1 \\
\hline $\begin{array}{l}\text { Yellow-olive } \\
\text { Flycatcher }\end{array}$ & Tolmomyias sulphurescens & Ins & M & Gle/Hov/Sal & 14.8 & 2 & 101 & 0.020 & 1 & 99 & 0.010 & 1 \\
\hline Tufted Antshrike & Mackenziaena severa & Ins & $\mathrm{U}$ & Gle/Sal & 51.3 & 2 & 16 & 0.125 & 0 & 0 & - & 0 \\
\hline $\begin{array}{l}\text { Black-goggled } \\
\text { Tanager }\end{array}$ & Thricothraupis melanops & Ins & $\mathrm{U}$ & Gle/Sal & 24.3 & 2 & 75 & 0.027 & 0 & 46 & 0.000 & 4 \\
\hline $\begin{array}{l}\text { Rufous-winged } \\
\text { Antwren }\end{array}$ & Herpsilochmus rufimarginatus & Ins & M & Gle/Sal/Lun & 10.4 & 1 & 34 & 0.029 & 0 & 4 & 0.000 & 0 \\
\hline $\begin{array}{l}\text { Golden-winged } \\
\text { Cacique }\end{array}$ & Cacicus chrysopterus & Ins & $\mathrm{C}$ & Pec/Pro/Han & 32.8 & 1 & 1 & 1.000 & 0 & 2 & 0.000 & 0 \\
\hline $\begin{array}{l}\text { Large-tailed } \\
\text { Antshrike }\end{array}$ & Mackenziaena leachii & Ins & $\mathrm{U}$ & Gle/Fla & 67.8 & 1 & 5 & 0.200 & 0 & 1 & 0.000 & 0 \\
\hline Euler's Flycatcher & Lathrotriccus euleri & Ins & $\mathrm{U}$ & Hov/Sal & 11 & 1 & 77 & 0.013 & 0 & 53 & 0.000 & 0 \\
\hline $\begin{array}{l}\text { Sharp-tailed } \\
\text { Streamcreeper }\end{array}$ & Lochmias nematura & Ins & $\mathrm{U}$ & Gle/Pro/Fla & 23 & 1 & 8 & 0.125 & 0 & 19 & 0.000 & 0 \\
\hline Streaked Xenops & Xenops rutilans & Ins & M & Pec/G/Han/Fla & 12.8 & 0 & 67 & 0.000 & 1 & 51 & 0.020 & 0 \\
\hline $\begin{array}{l}\text { Brassy-breasted } \\
\text { Tanager }\end{array}$ & Tangara desmaresti & Fru & $\mathrm{C}$ & Gle/Sal/Han & 19.8 & 0 & 0 & - & 1 & 15 & 0.067 & 3 \\
\hline $\begin{array}{l}\text { Olivaceous } \\
\text { Woodcreeper }\end{array}$ & Sitassomus griseicapillus & Ins & $\mathrm{U} / \mathrm{M}$ & Gle/Pec & 13.5 & 0 & 65 & 0.000 & 0 & 61 & 0.000 & 4 \\
\hline $\begin{array}{l}\text { Swallow-tailed } \\
\text { Manakin }\end{array}$ & Chriroxiphia caudata & Fru & $\mathrm{U}$ & Sal/Han & 25.6 & 0 & 59 & 0.000 & 0 & 105 & 0.000 & 4 \\
\hline $\begin{array}{l}\text { Sepia-capped } \\
\text { Flycatcher }\end{array}$ & Leptopogon amaurocephalus & Ins & $\mathrm{U}$ & Hov/Sal & 10.7 & 0 & 29 & 0.000 & 0 & 54 & 0.000 & 1 \\
\hline $\begin{array}{l}\text { Serra do Mar } \\
\text { Tyrant-Manakin }\end{array}$ & Neopelma chrysolophum & Fru & $\mathrm{U}$ & Sal/Han & 14 & 0 & 0 & - & 0 & 0 & - & 1 \\
\hline $\begin{array}{l}\text { White-necked } \\
\text { Thrush }\end{array}$ & Turdus albicollis & Ins & $\mathrm{U} / \mathrm{M}$ & $\begin{array}{l}\text { Gle/Sal/Han/Fla/Lu } \\
\text { n }\end{array}$ & 50 & 0 & 3 & 0.000 & 0 & 16 & 0.000 & 1 \\
\hline $\begin{array}{l}\text { Yellow-legged } \\
\text { Thrush }\end{array}$ & Turdus flavipes & Fru & $\mathrm{M} / \mathrm{C}$ & Gle/Sal/Han/Lun & 51.2 & 0 & 0 & - & 0 & 11 & 0 & 1 \\
\hline
\end{tabular}


Table 2. Model selection for spillover richness and abundance in coffee matrices. $B$ corresponds to spillover richness or abundance, AICc corresponds to the Akaike information criteria corrected for small samples, $\triangle \mathrm{AICc}$ is the difference from the AICc of the best ranked model ( $\triangle \mathrm{AICc}$ ), df is the degrees of freedom, and AICc $\omega \mathrm{i}$ is the evidence weight. Coefficients and standard errors (se) of each model are given. Var 1 corresponds to the first predictor variable in the model, Var 2 corresponds to the second predictor variable, and Interaction represents the interaction between the two. Forest cover corresponds the percentage of forest cover within a 800 $\mathrm{m}$ radius buffer around each sampling site (7.33 - $72.8 \%$, min-max), and edge density corresponds to the total density ( $\mathrm{m} / \mathrm{ha}$ ) of forest-non-forest edge within the same $800 \mathrm{~m}$ buffer (30.8 - $120.7 \mathrm{~m} / \mathrm{ha}$, min-max).

\begin{tabular}{|c|c|c|c|c|c|c|c|c|}
\hline \multirow{2}{*}{\multicolumn{5}{|c|}{ Spillover richness }} & & & & \\
\hline & & & & & \multicolumn{4}{|c|}{ Coefficients } \\
\hline Model & AICc & $\Delta$ AICc & df & AICc $\omega i$ & Intercept (se) & Var 1 (se) & Var 2 (se) & Interaction (se) \\
\hline$B \sim$ Null & 138.6 & 0 & 2 & 0.493 & $-2.185(0.099)$ & - & - & - \\
\hline$B \sim$ Forest cover & 140.4 & 1.8 & 3 & 0.198 & $-2.189(0.099)$ & $0.043(0.103)$ & - & - \\
\hline$B \sim$ Edge density & 140.6 & 2 & 3 & 0.181 & $-2.185(0.099)$ & $-0.002(0.103)$ & - & - \\
\hline$B \sim$ Forest cover + Edge density & 142.4 & 3.8 & 4 & 0.073 & $-2.189(0.099)$ & $0.043(0.103)$ & $-0.003(0.102)$ & - \\
\hline$B \sim$ Forest cover* Edge density & 143 & 4.4 & 5 & 0.055 & $-2.187(0.100)$ & $-0.002(0.109)$ & $0.099(0.138)$ & $-0.130(0.110)$ \\
\hline \multicolumn{5}{|l|}{ Spillover abundance } & \multicolumn{4}{|c|}{ Coefficients } \\
\hline Model & AICc & $\Delta$ AICc & df & AICc $\omega \mathrm{i}$ & Intercept (se) & Var 1 (se) & Var 2 (se) & Interaction (se) \\
\hline$B \sim$ Forest cover* Edge density & 214.2 & 0 & 5 & 0.956 & $-1.980(0.111)$ & $0.010(0.111)$ & $0.481(0.126)$ & $-0.327(0.115)$ \\
\hline$B \sim$ Edge density & 221.4 & 7.2 & 3 & 0.026 & $-1.944(0.088)$ & $0.247(0.083)$ & - & - \\
\hline$B \sim$ Forest cover + Edge density & 222.3 & 8.1 & 4 & 0.017 & $-1.943(0.084)$ & $0.093(0.086)$ & $0.232(0.081)$ & - \\
\hline$B \sim$ Null & 228.2 & 14 & 2 & $<0.001$ & $-1.924(0.091)$ & - & - & - \\
\hline$B \sim$ Forest cover & 228.4 & 14.2 & 3 & $<0.001$ & $-1.927(0.088)$ & $0.117(0.086)$ & - & - \\
\hline
\end{tabular}


work will be required to understand the biotic and abiotic challenges that bird species face when moving through high-contrasting matrices.
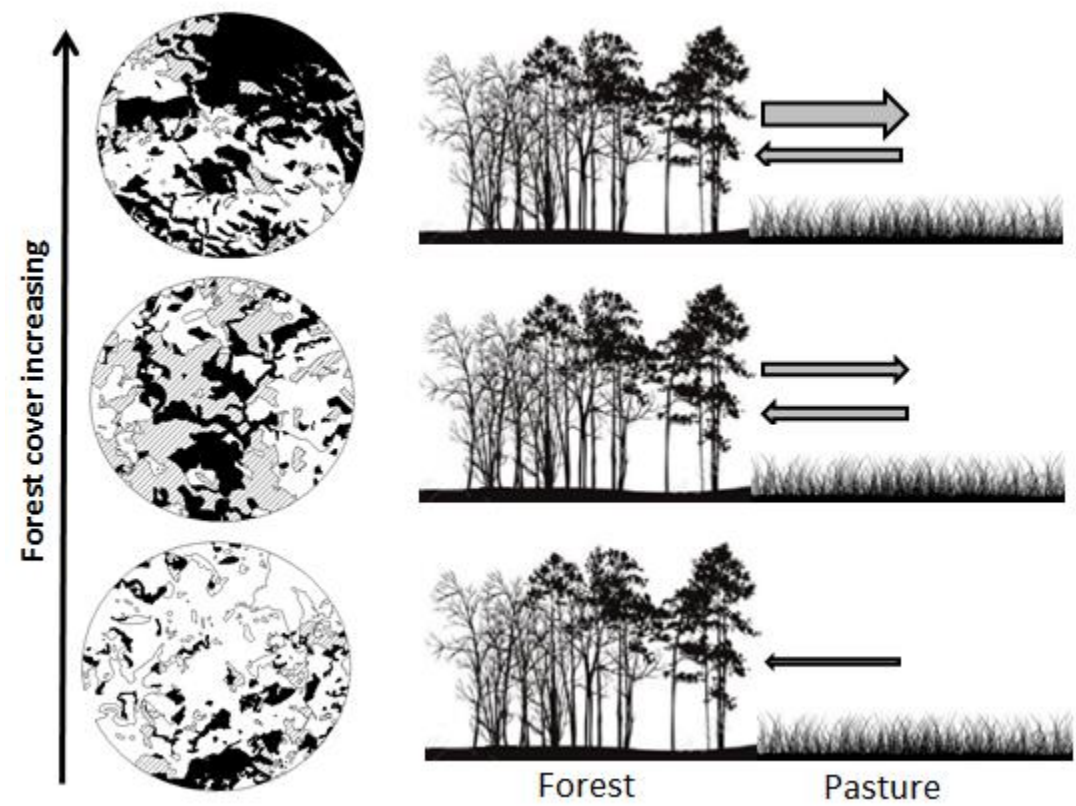

Figure 4. Number of birds caught at forest edges either leaving or entering (indicated by arrow direction) forest patches embedded in pasture matrices. The width of the arrow represents the intensity of the movement - the larger the width, the more species that were captured moving in that direction.

Spillover abundance into coffee matrices was explained by the interaction between forest cover and edge density. Under optimal conditions almost $30 \%$ of birds found in forest patches could spill over into coffee matrices, and spillover was maximized at high edge density, particularly in small amounts of habitat cover- an unexpected result. Since highest edge density occurs around 50\% of habitat amount (Fig. S6), we expected intensified spillover at this point of the forest cover gradient. However, spillover was intensified in very deforested landscapes, composed by fewer small and isolated forest patches, with a relatively high remaining edge density. We posit that a combination of two processes is driving this pattern. First, at lower amounts of habitat cover, habitat patches do not have enough resources to maintain in-patch bird populations and some individuals need to leave and search for complementary resources in other habitat patches (landscape supplementation) or in the matrix (landscape complementation) in 
order to fulfill their needs. This might suggest an in-patch density-dependent process occurring, which seems to be sustained by a positive correlation between abundance in-patch and the abundance inside coffee matrices ( $r=0.18$; Fig. SM3). As organisms' density accumulates inside forest patches, increased local competition for resources and interference between conspecifics may compel individuals to move to areas of lower density (Dunning et al. 1992).

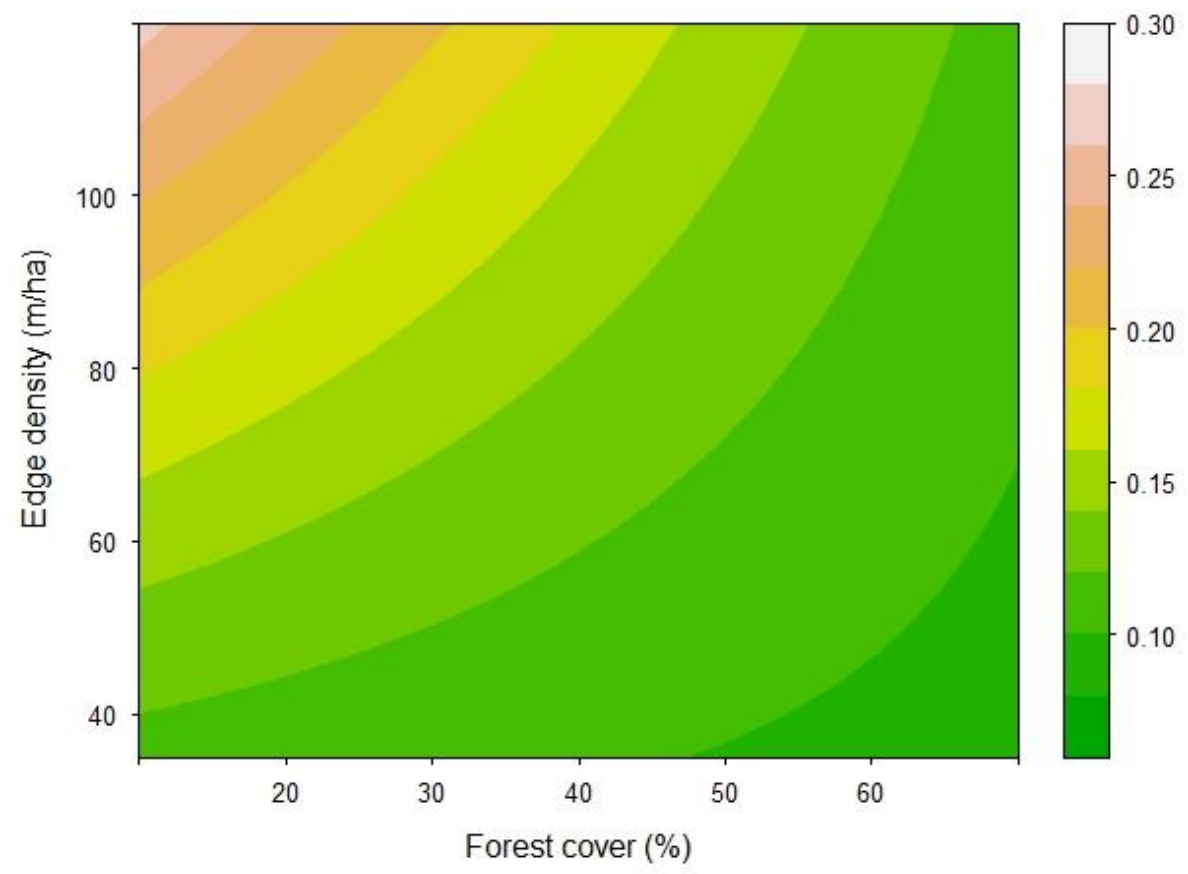

Figure 5. Predicted spillover abundance in coffee matrices, using the best ranked AICc model, which included an interaction between forest cover and edge density. The color scale bar to the right indicates the proportion of birds spilling over (from 0 to 0.30 ; spillover abundance).

Second, a higher edge density might facilitate species movement by increasing functional connectivity for those species that move through edges (Ries et al. 2004) or that use habitat edges more frequently (Metzger 2000), or by providing better access to different resource types (Dunning et al. 1992). A higher spillover to agricultural matrices was already observed for carabidae beetles in situations where edge density was high and edges presented low contrast (Duflot et al. 2016), suggesting that this process occur for different group of species. The original and unexpected result observed in our study sites is that edge density could be particularly important when habitat cover is low, combining thus a situation where birds are compiled to leave their original patches with a landscape 
configuration that can favor the movement of more generalist species through the landscape.

We also found no evidence that landscape structure influenced neither spillover richness nor individual spillover. There are two potential explanations for this pattern. First, given the diversity of species-specific responses to landscape structure documented for tropical Passerines (Gascon et al. 1999; Renjifo 2001), the use of a composite metric like spillover richness may not capture opposing responses of different species. Second, other unmeasured landscape factors may influence spillover, especially as we also failed to find a relationship between our landscape variables and individual spillover. An exploration of the variation in individual spillover of the two most abundant species found in coffee matrices suggests that when habitat cover is high, both the Golden-crowned Warbler (Basileuterus culicivorus) and the Variable Antshrike (Thamnophilus caerulescens) are observed deeper inside the coffee matrix (Table S4, Fig. S4, S5), maybe as a result of decreased isolation among habitat patches which motivate its movement further its source patch.

\section{Implications for provision of ecosystem services and landscape management}

Understanding the role that habitat configuration and composition play in the movements of service-providing organisms is a key applied management concern in the face of current agricultural expansion. In a recent review, Boesing and colleagues (in review) compiled evidence that over 226 avian predators provide insect control services in agricultural landscapes across both temperate and tropical regions. Of these, over 35\% of overall avian predators in tropical systems are dependent on native tropical forest habitat, clearly linking native habitat conservation and the maintenance of pest control services. In our study, most forest-dependent species spilling over into coffee matrices are small passerines and all the species are insectivores (see Table 1), which might have a substantial impact on the suppression of coffee pests. For example, the majority of spillover species were gleaning feeders that actively target prey on leaves, sticks, or ground - a feeding strategy that might target the coffee-borer beetle (Hypothenemus hampei). Another significant proportion of spillover species instead have a sallypouncing foraging behavior, in which species strike their prey in the air - a foraging 
strategy that might facilitate capture of the coffee-leaf miner (Leucoptera coffeella). Despite the remarkable lack of information regarding the identity of bird predators feeding on crop pests in Brazilian coffee plantations, two bird species (Goldencrowned Warbler B. culicivorus and Flavescent Warbler B. flaveolus) that were often recorded in our study system using coffee matrices, are congeners with an important predator of coffee-borer beetle in Central America (Rufous-capped Warbler, B. rufifrons; Karp et al. 2013), suggesting that spillover into coffee plantations can have an important effect in coffee pest control.

The observed pattern of spillover suggests that landscape configuration and matrix composition should be considered when planning agricultural landscapes in order to ensure ecosystem services provision. First, maintaining native habitat patches adjacent to crop fields preserves the source of individuals and increases landscape connectivity. There is evidence that habitat patches might provide many benefits in agricultural systems, providing not only avian-predators (Kellermann et al. 2008; Koh 2008), but also other natural enemies of insect pests (Lucey \& Hill 2012; Gray et al. 2016), and different pollinators (Ricketts 2004; Monasterolo et al. 2015; Saturni et al. 2016). Second, increasing matrix permeability is key facilitating avian cross-habitat spillover. Even though large-scale conversion to high-quality matrices might not be a realistic option, even small changes to part of the matrix may be a feasible and effective action especially in terms of ecosystem service provision. Matrix permeability might also be increased through enhancement of crop diversity, and decreased land management intensity (Perfecto \& Vandermeer 2010). Third, increasing landscape heterogeneity could be a key management strategy to facilitate cross-habitat spillover of habitat-dependent species and provide ecosystem services. Increasing elements' diversity in agricultural landscapes, such as stepping stones, strips, or even hedgerows, may be very beneficial for many forest-dependent species that can use these elements to move through matrices (Uezu et al. 2008).

Finally, it is important to highlight that avian predator-mediated ecosystem service provision will be influenced by both functional traits that shape bird dietary preferences, but also traits that influence a species' propensity for movement and willingness to cross gaps (Awade \& Metzger 2008; Boscolo et al. 2008; Brudvig et al. 2009; Tscharntke et al. 2012). For instance, the Golden-crowned 
Warbler, which often uses coffee plantations and is occasionally caught at the edges of pastures, might easily cross gaps smaller than 55 m (Awade \& Metzger 2008). However, the White-shouldered Fire-eye, which has not been recorded in pasture matrices, does not cross gaps larger than 25 m (Awade 2008), reflecting different abilities to move across matrices. Moreover, species spilling over into coffee matrices are not the same ones travelling across pastures (with few exceptions of four shared species; see Table 1), demonstrating that the matrix can act as a semipermeable filter. For instance, most spilling over species into coffee matrices are understory insectivores, while species traveling through pastures are often midstory or canopy fruit-eating species. Collecting and integrating information which species cross and use which matrix habitats and the functional traits associated with foraging will permit a more generalized understanding of the overall implications of matrix composition and landscape structure on avianmediated ecosystem service provision in changing working landscapes.

Meaningful advancement towards the design and management of multifunctional landscapes capable of maintaining both biodiversity and agricultural production is a fundamental pillar of sustainable agricultural production systems (Balmford et al. 2012). This will critically require that we understand how the composition and configuration of working landscapes influence biodiversity. Here we contribute with evidence that (i) matrix composition plays a key role in facilitating bird movements into agricultural matrices, (ii) that edge density has important effects on spillover in more permeable matrices, especially in lower amounts of habitat, and (iii) habitat amount is important promoting spillover when matrix and native habitats have high-contrast. Highly-connected crop-noncrop mosaics may be best for long-term conservation of ecosystem services (Tscharntke et al. 2007). Continued efforts are necessary to more fully understand how and why landscape configuration and composition influence forest-dependent mobile organisms and biodiversitymediated-ecosystem services especially in fragmented tropical landscapes.

\section{Acknowledgments}

This study was developed within the "Interface Project", supported by São Paulo Research Foundation (FAPESP, 2013/23457-6). A.L.B was supported by doctoral 
fellowships from the Brazilian Ministry of Education (CAPES-DS; 2012-2013), and São Paulo Research Foundation (FAPESP) (2013/12777-0). E.N. was supported by post-doctoral fellowships from the National Science Foundation grant (1158817) and the São Paulo Research Foundation (FAPESP) (2014/11676-8). J.P.M. was funded by National Council for Scientific and Technological Development (CNPQ, process number: 307934/2011-0). We thank Kelley Langhans for reviewing the English, and Leandro Tambosi and Adrian Gonzalez for important initial discussions.

\section{Literature cited}

Anjos L. (2003). A eficiência do método de amostragem por pontos de escuta na avaliação da riqueza de aves. Revista Brasileira de Ornitologia, 15, 239-243.

Anjos L., Collins C.D., Holt R.D., Volpato G.H., Mendonca L.B., Lopes E.V., Bocon R., Bisheimer M.V., Serafini P.P. \& Carvalho J. (2011). Bird species abundanceoccupancy patterns and sensitivity to forest fragmentation: Implications for conservation in the Brazilian Atlantic forest. Biol Conserv, 144, 2213-2222.

Awade M. (2008). A importância de uma visão probabilística da conectividade funcional na predição da incidência de uma espécie de ave em paisagens fragmentadas. In: Departamento de Ecologia. Universidade de São Paulo, p. 84.

Awade M. \& Metzger J.P. (2008). Using gap-crossing capacity to evaluate functional connectivity of two Atlantic rainforest birds and their response to fragmentation. Austral Ecol, 33, 863-871.

Baguette M., Blanchet S., Legrand D., Stevens V.M. \& Turlure C. (2012). Individual dispersal, landscape connectivity and ecological networks. Biol Rev, 1-17.

Balmford A., Green R. \& Phalan B. (2012). What conservationists need to know about farming. P Roy Soc B-Biol Sci, 279, 2714-2724.

Banks-Leite C., Ewers R.M., Kapos V., Martensen A.C. \& Metzger J.P. (2011). Comparing species and measures of landscape structure as indicators of conservation importance. J Appl Ecol, 48, 706-714.

Banks-Leite C., Ewers R.M. \& Metzger J.P. (2012). Unraveling the drivers of community dissimilarity and species extinction in fragmented landscapes. Ecology, 93, 25602569.

Bates D., Maechler M., Bolker B., Walker S., Christensen R.H.B., Singmann H., Dai B., Grothendieck G. \& Green P. (2016). Ime4: Linear Mixed-Effects Models using 
'Eigen' and S4. $\mathrm{R}$ package version 1.1-12. URL https://cran.rproject.org/web/packages/lme4/index.html

Bianchi F.J.J.A., Booij C.J.H. \& Tscharntke T. (2006). Sustainable pest regulation in agricultural landscapes: a review on landscape composition, biodiversity and natural pest control. P Roy Soc B-Biol Sci, 273, 1715-1727.

Bibby C.J., Burgess N.D., Hill D.A. \& Mustoe S.H. (2002). Bird Census Techniques. Second Edition edn. Academic Press, London, UK.

Blake J.G. (2007). Neotropical forest bird communities: A comparison of species richness and composition at local and regional scales. Condor, 109, 237-255.

Blitzer E.J., Dormann C.F., Holzschuh A., Klein A.-M., Rand T.A. \& Tscharntke T. (2012). Spillover of functionally important organisms between managed and natural habitats. Agr Ecosyst Environ, 146, 34-43.

Blondel J., Ferry C. \& Frochot B. (1970). [The point count method to recording bird from hearing spots]. Alauda, 38, 55-71.

Boesing A.L., Nichols E. \& Metzger J.P. (In prep). The role of matrix composition determining extinction thresholds of tropical avian communities

Boesing L., Nichols E. \& Metzger J.P. (in review). Landscape structure and avian-mediated pest control.

Bolker B. (2016). bbmle: tools for general maximum likelihood estimation. R package $\begin{array}{llll}\text { version } & \text { 1.0.18. } & \text { Available } & \text { at: }\end{array}$ project.org/web/packages/bbmle/index.html. Accessed on October 26th 2016.

Boscolo D., Candia-Gallardo C., Awade M. \& Metzger J.P. (2008). Importance of interhabitat gaps and stepping-stones for lesser woodcreepers (Xiphorhynchus fuscus) in the Atlantic forest, Brazil. Biotropica, 40, 273-276.

Boscolo D. \& Metzger J.P. (2009). Is bird incidence in Atlantic forest fragments influenced by landscape patterns at multiple scales? Landscape Ecol, 24, 907-918.

Brooks T.M., Mittermeier R.A., Mittermeier C.G., da Fonseca G.A.B., Rylands A.B., Konstant W.R., Flick P., Pilgrim J., Oldfield S., Magin G. \& Hilton-Taylor C. (2002). Habitat loss and extinction in the hotspots of biodiversity. Conserv Biol, 16, 909-923.

Brudvig L.A., Damschen E.I., Tewksbury J.J., Haddad N.M. \& Levey D.J. (2009). Landscape connectivity promotes plant biodiversity spillover into non-target habitats. P Natl Acad Sci USA, 106, 9328-9332.

Burnham K.P. \& Anderson D.R. (2002). Model selection and multimodel inference. A practical information-theoritical approach. Springer, New York. 
Collinge S.K. \& Palmer T.M. (2002). The influences of patch shape and boundary contrast on insect response to fragmentation in California grasslands. Landscape Ecol, 17, 647-656.

del Hoyo J., Elliott A., Sargatal J., Christie D.A. \& Juana E. (2014). Handbook of the Birds of the World Alive. In. Linx Edicions Barcelons.

Duflot R., Ernoult A., Burel F. \& Aviron S. (2016). Landscape level processes driving carabid crop assemblage in dynamic farmlands. Popul Ecol, 58, 265-275.

Dunn E.H. \& Ralph C.J. (2004). The use of mist nets as a tool for bird population monitoring. Studies in Avian Biology, 29, 1-6.

Dunning J.B., Danielson B.J. \& Pulliam H.R. (1992). Ecological processes that affect populations in complex landscapes. Oikos, 65, 169-175.

EMBRAPA (2016). Available at: https://www.embrapa.br/. Accessed on October $26^{\text {th }}$ 2016.

Esquivel M.A. \& Peris S. (2008). Influence of time of day, duration and number of counts in point count sampling of birds in an Atlantic forest of Paraguay. Ornitologia Neotropical, 19, 229-242.

Estavillo C., Pardini R. \& Bernardo da Rocha P.L. (2013). Forest Loss and the Biodiversity Threshold: An Evaluation Considering Species Habitat Requirements and the Use of Matrix Habitats. Plos One, 8.

Fahrig L. (2002). Effect of habitat fragmentation on the extinction threshold: A synthesis. Ecol Appl, 12, 346-353.

Fahrig L. (2003). Effects of habitat fragmentation on biodiversity. Annu Rev Ecol Evol S, 34, 487-515.

Fox J., Weisberg S., Adler D., Bates D., Baud-Bovy G., Ellison S., Firth D., Friendly M., Gorjanc G., Graves S., Heiberger R., Laboissieri R., Monette G., Murdoch D., Nilsson H., Ogle D., Ripley E., Venables W., Winsemius D. \& Zeleis A. (2016). car: Companion to Applied Regression. $\mathrm{R}$ package version 2.1-3. Available at: https://cran.rproject.org/web/packages/car/index.html. Accessed in October 28 2016.

Frost C.M., Didham R.K., Rand T.A., Peralta G. \& Tylianakis J.M. (2015). Community-level net spillover of natural enemies from managed to natural forest. Ecology, 96, 193202.

Gascon C., Lovejoy T.E., Bierregaard R.O., Malcolm J.R., Stouffer P.C., Vasconcelos H.L., Laurance W.F., Zimmerman B., Tocher M. \& Borges S. (1999). Matrix habitat and species richness in tropical forest remnants. Biol Conserv, 91, 223-229. 
Gonzalez E., Salvo A., Defago M.T. \& Valladares G. (2016). A Moveable Feast: Insects Moving at the Forest-Crop Interface Are Affected by Crop Phenology and the Amount of Forest in the Landscape. Plos One, 11.

Gray C.L., Simmons B.I., Fayle T.M., Mann D.J. \& Slade E.M. (2016). Are riparian forest reserves sources of invertebrate biodiversity spillover and associated ecosystem functions in oil palm landscapes? Biol Conserv, 194, 176-183.

Holt R.D. (1996). Food webs in space: an island biogeographic perspective. In: Food webs: contemporary perspectives (eds. Polis GA \& Winemiller K). Chapman and Hall, pp. 313-323.

Joly C.A., Metzger J.P. \& Tabarelli M. (2014). Experiences from the Brazilian Atlantic Forest: ecological findings and conservation initiatives. New Phytologist, 204, 459-473.

Karp D.S., Mendenhall C.D., Sandi R.F., Chaumont N., Ehrlich P.R., Hadly E.A. \& Daily G.C. (2013). Forest bolsters bird abundance, pest control and coffee yield. Ecol Lett, 16, $1339-1347$.

Kellermann J.L., Johnson M.D., Stercho A.M. \& Hackett S.C. (2008). Ecological and Economic Services Provided by Birds on Jamaican Blue Mountain Coffee Farms. Conserv Biol, $22,1177-1185$.

Koh L.P. (2008). Birds defend oil palms from herbivorous insects. Ecol Appl, 18, 821-825.

Kremen C., Williams N.M., Aizen M.A., Gemmill-Herren B., LeBuhn G., Minckley R., Packer L., Potts S.G., Roulston T.a., Steffan-Dewenter I., Vazquez D.P., Winfree R., Adams L., Crone E.E., Greenleaf S.S., Keitt T.H., Klein A.-M., Regetz J. \& Ricketts T.H. (2007). Pollination and other ecosystem services produced by mobile organisms: a conceptual framework for the effects of land-use change. Ecol Lett, 10, 299-314.

Lira P.K., Ewers R.M., Banks-Leite C., Pardini R. \& Metzger J.P. (2012). Evaluating the legacy of landscape history: extinction debt and species credit in bird and small mammal assemblages in the Brazilian Atlantic Forest. J Appl Ecol, 49, 1325-1333.

Livingston G., Jha S., Vega A. \& Gilbert L. (2013). Conservation Value and Permeability of Neotropical Oil Palm Landscapes for Orchid Bees. Plos One, 8.

Lucey J.M. \& Hill J.K. (2012). Spillover of Insects from Rain Forest into Adjacent Oil Palm Plantations. Biotropica, 44, 368-377.

Lynch J.F. (1995). Effects of point count duration, time-of-day, and aural stimuli on detectability of migratory and resident species in Quintana Roo, Mexico. In: Monitoring bird population by point counts (eds. Ralph CJ, Sauer JR \& Droege S). USDA Forest Service General Technical Report PSW-GTR-149 Albany, CA, pp. 1-6.

Maas B., Tscharntke T., Saleh S., Putra D.D. \& Clough Y. (2015). Avian species identity drives predation success in tropical cacao agroforestry. J Appl Ecol, 52, 735-743. 
Marini M.A. (2010). Bird movement in a fragmented Atlantic Forest landscape. Studies on Neotropical Fauna and Environment, 45, 1-10.

Martensen A.C., Ribeiro M.C., Banks-Leite C., Prado P.I. \& Metzger J.P. (2012). Associations of Forest Cover, Fragment Area, and Connectivity with Neotropical Understory Bird Species Richness and Abundance. Conserv Biol, 26, 1100-1111.

McCoy M.W., Barfield M. \& Holt R.D. (2009). Predator shadows: complex life histories as generators of spatially patterned indirect interactions across ecosystems. Oikos, $118,87-100$.

Monasterolo M., Musicante M.L., Valladares G.R. \& Salvo A. (2015). Soybean crops may benefit from forest pollinators. Agr Ecosyst Environ, 202, 217-222.

Myers N., Mittermeier R.A., Mittermeier C.G., da Fonseca G.A.B. \& Kent J. (2000). Biodiversity hotspots for conservation priorities. Nature, 403, 853-858.

Oliveira A.T. \& Fontes M.A.L. (2000). Patterns of floristic differentiation among Atlantic forests in southeastern Brazil and the influence of climate. Biotropica, 32, 793-810.

Pasher J., Mitchell S.W., King D.J., Fahrig L., Smith A.C. \& Lindsay K.E. (2013). Optimizing landscape selection for estimating relative effects of landscape variables on ecological responses. Landscape Ecol, 28, 371-383.

Perfecto I. \& Vandermeer J. (2010). The agroecological matrix as alternative to the landsparing/agriculture intensification model. P Natl Acad Sci USA, 107, 5786-5791.

Perovic D.J., Gurr G.M., Raman A. \& Nicol H.I. (2010). Effect of landscape composition and arrangement on biological control agents in a simplified agricultural system: A cost-distance approach. Biol Control, 52, 263-270.

Pompeu P., Costa M. \& Fontes M.A. (2009). Classificação e apresentação dos parâmetros climáticos de Poços de Caldas - MG. In: III Congresso Latino Americano de Ecologia São Lourenço, Minas Gerais.

R Development Core Team (2016). R: A Language and Environment for Statistical Computing. In. R Foundation for Statistical Computing Vienna, Austria.

Rand T.A. \& Louda S.A. (2006). Spillover of agriculturally subsidized predators as a potential threat to native insect herbivores in fragmented landscapes. Conserv Biol, $20,1720-1729$.

Rand T.A., Tylianakis J.M. \& Tscharntke T. (2006). Spillover edge effects: the dispersal of agriculturally subsidized insect natural enemies into adjacent natural habitats. Ecol Lett, 9, 603-614.

Renjifo L.M. (2001). Effect of natural and anthropogenic landscape matrices on the abundance of subandean bird species. Ecol Appl, 11, 14-31. 
Ribeiro M.C., Metzger J.P., Martensen A.C., Ponzoni F.J. \& Hirota M.M. (2009). The Brazilian Atlantic Forest: How much is left, and how is the remaining forest distributed? Implications for conservation. Biol Conserv, 142, 1141-1153.

Ricketts T.H. (2004). Tropical forest fragments enhance pollinator activity in nearby coffee crops. Conserv Biol, 18, 1262-1271.

Ricketts T.H., Williams N.M. \& Mayfield M.M. (2006). Connectivity and ecosystem services: crop pollination in agricultural landscapes. In: Connectivity for Conservation (eds. Sanjayan M \& Crooks K). Cambridge University Press Cambridge, UK, pp. 255-289.

Ries L., Fletcher R.J., Battin J. \& Sisk T.D. (2004). Ecological responses to habitat edges: Mechanisms, models, and variability explained. Annu Rev Ecol Evol S, 35, 491-522.

Saturni F.T., Jaffé R. \& Metzger J.P. (2016). Landscape structure influences bee community and coffee pollination at different spatial scales. Agriculture, Ecosystems, and Environment, 235, 1-12.

Schneider G., Krauss J., Boetzl F.A., Fritze M.A. \& Steffan-Dewenter I. (2016). Spillover from adjacent crop and forest habitats shapes carabid beetle assemblages in fragmented semi-natural grasslands. Oecologia, In press.

Sekercioglu C.H., Wenny D.G. \& Whelan C.J. (2016). Why birds matter: avian ecological function and ecosystem services. The University of Chicago Press, Chicago, London.

Sick H. (1997). Ornitologia Brasileira. Nova Fronteira, Rio de Janeiro.

Silva M.R.B. (2012). Efeitos de diferentes matrizes no risco de predação e na movimentação de uma ave florestal. In: Departamento de Ecologia. Universidade de São Paulo São Paulo, p. 64.

Taylor P.D., Fahrig L., Henein K. \& Merriam G. (1993). Connectivity is a vital element of landscape structure. Oikos, 68, 571-573.

Thies C., Roschewitz I. \& Tscharntke T. (2005). The landscape context of cereal aphidparasitoid interactions. P Roy Soc B-Biol Sci, 272, 203-210.

Tscharntke T., Bommarco R., Clough Y., Crist T.O., Kleijn D., Rand T.A., Tylianakis J.M., van Nouhuys S. \& Vidal S. (2007). Conservation biological control and enemy diversity on a landscape scale. Biol Control, 43, 294-309.

Tscharntke T., Tylianakis J.M., Rand T.A., Didham R.K., Fahrig L., Batary P., Bengtsson J., Clough Y., Crist T.O., Dormann C.F., Ewers R.M., Frund J., Holt R.D., Holzschuh A., Klein A.M., Kleijn D., Kremen C., Landis D.A., Laurance W., Lindenmayer D., Scherber C., Sodhi N., Steffan-Dewenter I., Thies C., van der Putten W.H. \& Westphal C. (2012). Landscape moderation of biodiversity patterns and processes - eight hypotheses. Biol Rev, 87, 661-685. 
Uezu A., Beyer D.D. \& Metzger J.P. (2008). Can agroforest woodlots work as stepping stones for birds in the Atlantic Forest region? . Biodivers Conserv, 17, 1907-1922.

UNICAMP C. (2016). Clima dos municipios paulistas. Available at: http://www.cpa.unicamp.br/outras-informacoes/clima-dos-municipiospaulistas.html. Accessed in October 28 2016.

Villard M.-A. \& Metzger J.P. (2014). Beyond the fragmentation debate: a conceptual model to predict when habitat configuration really matters. J Appl Ecol, 51, 309-318.

Whelan C.J., Wenny D.G. \& Marquis R.J. (2008). Ecosystem services provided by birds. Year in Ecology and Conservation Biology 2008, 1134, 25-60. 


\section{Supplementary material}

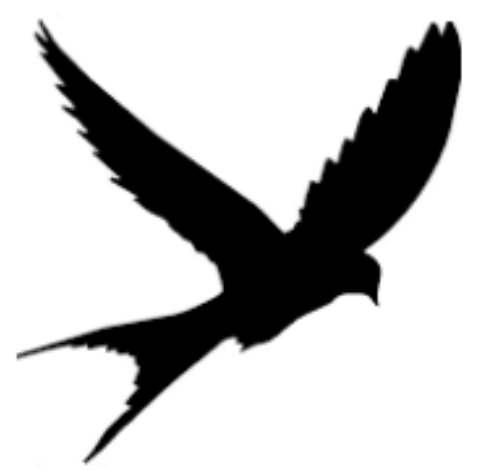


Table S1. Forest-dependent species recorded in the whole study region in forest patches embedded in both pasture and coffee matrices. Nomenclature follows del Hoyo et al. (2014).

\begin{tabular}{|c|c|c|c|}
\hline Scientific name & Common name & Pasture & Coffee \\
\hline Accipiter striatus & Sharp-shinned Hawk & $\mathrm{X}$ & \\
\hline Anabazenops fuscus & $\begin{array}{l}\text { White-collared Foliage- } \\
\text { gleaner }\end{array}$ & X & $\mathrm{X}$ \\
\hline Arremon flavirostris & Saffron-billed Sparrow & & $\mathrm{X}$ \\
\hline Arremon semitorquatus & Half-collared Sparrow & $\mathrm{X}$ & \\
\hline Attila phoenicurus & Rufous-tailed Attila & $\mathrm{X}$ & \\
\hline Attila rufus & Grey-hooded Attila & $\mathrm{X}$ & \\
\hline Automolus leucophthalmus & White-eyed Foliage gleaner & $\mathrm{X}$ & $\mathrm{X}$ \\
\hline Baryphthengus rufucapillus & Rufous-capped Motmot & $\mathrm{X}$ & $\mathrm{X}$ \\
\hline Basileuterus culicivorus & Golden-crowned Warbler & $\mathrm{X}$ & $\mathrm{X}$ \\
\hline Basileuterus flaveolus & Flavescent Warbler & & $\mathrm{X}$ \\
\hline Basileuterus leucoblepharus & White-browed Warbler & $\mathrm{X}$ & $\mathrm{X}$ \\
\hline Batara cinerea & Giant Antshrike & $\mathrm{X}$ & \\
\hline Cacicus chrysopterus & Golden-winged Cacique & $\mathrm{X}$ & $\mathrm{X}$ \\
\hline Campephilus robustus & Robust Woodpecker & & $\mathrm{X}$ \\
\hline Carpornis cucullata & Hooded Barryeater & $\mathrm{X}$ & \\
\hline Celeus flavescens & Blond-crested Woodpecker & $\mathrm{X}$ & $\mathrm{X}$ \\
\hline Chamaeza campanisona & Short-tailed Antthrush & & $\mathrm{X}$ \\
\hline Chamaeza meruloides & Cryptic Antthrush & $\mathrm{X}$ & $\mathrm{X}$ \\
\hline Chiroxiphia caudata & Blue Manakin & $\mathrm{X}$ & $\mathrm{X}$ \\
\hline Cissopis leverianus & Magpie Tanager & $\mathrm{X}$ & \\
\hline Cnemotriccus fuscatus & Fuscous Flycather & $\mathrm{X}$ & $\mathrm{X}$ \\
\hline Conirostrum speciosum & Chestnut-vented Conebill & $\mathrm{X}$ & $\mathrm{X}$ \\
\hline Conopophaga lineata & Rufous Gnateater & $\mathrm{X}$ & $\mathrm{X}$ \\
\hline Corythopis delalandi & Southern Antpipit & $\mathrm{X}$ & $\mathrm{X}$ \\
\hline Cranioleuca pallida & Pallid Spinetail & $\mathrm{X}$ & $\mathrm{X}$ \\
\hline Crypturellus obsoletus & Brown Tinamou & $\mathrm{X}$ & $\mathrm{X}$ \\
\hline Dendrocolaptes platyrostris & Planalto Woodpcreeper & $\mathrm{X}$ & $\mathrm{X}$ \\
\hline Dromoccoccys pavoninus & Pavonine Cucko & $\mathrm{X}$ & \\
\hline Drymophia rubricollis & Bertoni's Antbird & $\mathrm{X}$ & $\mathrm{X}$ \\
\hline Drymophila ferruginea & Ferrugineous Antbird & $\mathrm{X}$ & $\mathrm{X}$ \\
\hline Drymophila malura & Dusky-tailed Antbird & $\mathrm{X}$ & $\mathrm{X}$ \\
\hline Drymophila ochropyga & Ochre-rumped Antbird & $\mathrm{X}$ & $\mathrm{X}$ \\
\hline Drymophila squamata & Scaled Antbird & $\mathrm{X}$ & \\
\hline Dysithamnus mentalis & Plain Antvireo & $\mathrm{X}$ & $\mathrm{X}$ \\
\hline Euphonia chalybea & Green-chinned Euphonia & $\mathrm{X}$ & \\
\hline Euphonia pectoralis & Chestnut-bellied Euphonia & $\mathrm{X}$ & \\
\hline Geotrygon montana & Ruddy Quail-dove & $\mathrm{X}$ & \\
\hline Geotrygon violacea & Violaceous Quail-dove & $\mathrm{X}$ & \\
\hline Grallaria varia & Variegated Antpitta & $\mathrm{X}$ & $\mathrm{X}$ \\
\hline
\end{tabular}


Habia rubica

Herpsilochmus longirostris

Herpsilochmus rufimarginatus

Hylophilus poicilotis

Hypoedaleus guttatus

Lathrotriccus euleri

Lepidocolaptes squamatus

Leptopogon amaurocephalus

Leptotila rufaxilla

Lochmias nematura

Mackenziaena leachii

Mackenziaena severa

Malacoptila striata

Micrastur ruficapillus

Micrastur semitorquatus

Mionectes rufiventris

Myiopagis caniceps

Myiornis auricularis

Myrmeciza squamosa

Odontophorus capueira

Pachyramphus castaneus

Pachyramphus validus

Pachyramphus viridis

Penelope obscura

Philydor rufum

Phyllomyias fasciatus

Phylloscartes ventralis

Platyrinchus mystaceus

Poecilotriccus plumbeiceps

Pogonotriccus eximius

Psilorhamphus guttatus

Pteroglossus bailloni

Pyriglena leucoptera

Pyroderus scutatus

Pyrrhocoma ruficeps

Saltator fuliginosus

Saltator maxillosus

Schiffornis virescens

Sclerurus scansor

Sirystes sibilator

Sittasomus griseicapillus

Sporophila frontalis

Synallaxis cinerascens

Synallaxis ruficapilla

Syndactyla rufosuperciliata

Tangara cyanoventris
Red-crowed Ant-tanager

$\mathrm{X}$

Large-billed Antwren X

Rufous-winged Antwren $\quad X \quad X$

Rufous-crownd Greenlet $\quad X \quad X$

Spot-backed Antshrike $\quad X \quad X$

Euler's Flycatcher $\quad X \quad X$

Scaled Woodcreeper $\quad X \quad X$

Sepia-capped Flycatcher $\quad X \quad X$

Grey-fronted Dove X X

Sharp-tailed Streamcreeper $\quad X \quad X$

Large-tailed Antshrike X X

Tufted Antshrike X

Greater Crescent-chested X

Puffbird

Barred Forest-falcon X

Collared Forest-falcon X

Grey-hooded Flycatcher $\quad$ X $\quad X$

Grey Elaenia $\quad X \quad X$

Eared-Pygmy-tyrant $\quad X \quad X$

Squamate Antbird $\mathrm{X}$

Spot-winged Wood-quail X

Chestnut-crowned Becard X X

Plain Becard X

Green-backed Becard X X

Dusky-legged Guan X X

Buff-fronted Foliage-gleaner $\quad X \quad X$

$\begin{array}{lll}\text { Planalto Tyrannulet } & \mathrm{X}\end{array}$

Mottle-cheeked Tyrannulet X X

White-throated Spadebill X X

Ochre-faced Tody-flycatcher X X

Southern Bristle-tyrant $\quad \mathrm{X}$

Spotted Bamboowren $\quad X$

Saffron Toucanet $\mathrm{X}$

White-shouldered Fire-eye X X

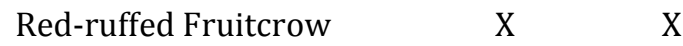

Chestnut-headed Tanager X X

Black-throated Grosbeak X

Thick-billed Saltator X

Greenish Mourner X X

Rufous-breasted Leaftosser $\quad X \quad X$

$\begin{array}{lll}\text { Sirystes } & \mathrm{X} & \mathrm{X}\end{array}$

Olivaceous Woodcreeper $\quad \mathrm{X} \quad \mathrm{X}$

Buffy-fronted Seedater $\quad X$

Grey-bellied Spinetail $\quad X \quad X$

Rufous-capped Spinetail X X

Buff-browed Foliage-gleaner X X

$\begin{array}{lll}\text { Gilt-edged Tanager } & X\end{array}$ 


\begin{tabular}{llll} 
Tangara desmaresti & Brassy-breasted Tanager & X & \\
Terenura maculata & Streak-capped Antwren & X & \\
Thamnophilus caerulescens & Variable Antshrike & X & X \\
Tolmomyias sulphurescens & Yellow-olive Flycatcher & X & X \\
Trichothraupis melanops & Black-goggled Tanager & X & X \\
Trogon rufus & Black-throated Trogon & $\mathrm{X}$ & \\
Trogon surrucura & Southern Surucua Trogon & $\mathrm{X}$ & $\mathrm{X}$ \\
Turdus albicollis & White-throated Thrush & $\mathrm{X}$ & $\mathrm{X}$ \\
Turdus flavipes & Yellow-legged Thrush & $\mathrm{X}$ & \\
Xenops rutilans & Streaked Xenops & $\mathrm{X}$ & $\mathrm{X}$ \\
Xyphorhynchus fuscus & Lesser Woodcreeper & $\mathrm{X}$ & $\mathrm{X}$ \\
\hline
\end{tabular}


Table S2. Model selection for individual spillover abundance for the six most abundant species that spill over into coffee matrices. $B$ corresponds to individual spillover, AICc corresponds to the Akaike Information Criteria corrected to small samples, $\Delta$ AICc is the difference between AICc from the best ranked model ( $\triangle \mathrm{AICc}$ ), df is the degrees of freedom, and AICc wi is the evidence weight. Coefficients and standard errors (se) of each model are given. Var 1 corresponds to the first predictor variable in the model, Var 2 corresponds to the second predictor variable, and Interaction represents the interaction between the two. Forest cover corresponds to the percentage of forest cover around each sampling site within 800 m radius buffer (7.33 - 72.8\%, min-max), and edge density corresponds to the total area in hectares of forest-non-forest edge / area within the same $800 \mathrm{~m}$ buffer (30.8 - $120.7 \mathrm{~m} / \mathrm{ha}$, min-max).

\begin{tabular}{|c|c|c|c|c|c|c|c|c|}
\hline Spilling over species & AICc & $\Delta$ AICc & df & AICc $\omega \mathbf{i}$ & Intercept (se) & Var 1 (se) & Var 2 (se) & $\begin{array}{l}\text { Interaction } \\
\text { (se) }\end{array}$ \\
\hline \multicolumn{9}{|l|}{ Basileuterus culicivorus } \\
\hline$B \sim$ Null & 101.5 & 0 & 2 & 0.37 & $-1.061(0.173)$ & - & - & - \\
\hline$B \sim$ Forest cover & 102.4 & 0.8 & 3 & 0.24 & $-1.077(0.171)$ & $0.183(0.169)$ & - & - \\
\hline$B \sim$ Edge density & 103.1 & 1.6 & 3 & 0.17 & $-1.064(0.173)$ & $0.106(0.170)$ & - & - \\
\hline$B \sim$ Forest cover* Edge density & 103.9 & 2.3 & 5 & 0.12 & $-1.084(0.178)$ & $0.322(0.246)$ & $0.072(0.185)$ & $-0.267(0.190)$ \\
\hline$B \sim$ Forest cover + Edge density & 104 & 2.5 & 4 & 0.11 & $-1.080(0.175)$ & $0.094(0.166)$ & $0.180(0.171)$ & - \\
\hline \multicolumn{9}{|l|}{ Thamnophilus caerulescens } \\
\hline$B \sim$ Forest cover & 68.2 & 0 & 3 & 0.36 & $-1.131(0.232)$ & $0.362(0.207)$ & - & - \\
\hline$B \sim$ Null & 69.3 & 1.1 & 2 & 0.2 & $-1.049(0.219)$ & - & - & - \\
\hline$B \sim$ Forest cover + Edge density & 69.7 & 1.5 & 4 & 0.17 & $-1.149(0.236)$ & $0.127(0.188)$ & $0.360(0.210)$ & - \\
\hline$B \sim$ Forest cover* Edge density & 69.8 & 1.6 & 5 & 0.16 & $-1.182(0.248)$ & $0.462(0.336)$ & $0.260(0.221)$ & $-0.313(0.239)$ \\
\hline$B \sim$ Edge density & 70.7 & 2.5 & 3 & 0.1 & $-1.070(0.222)$ & $0.152(0.194)$ & - & - \\
\hline
\end{tabular}




\begin{tabular}{|c|c|c|c|c|c|c|c|c|}
\hline$B \sim$ Null & 73.7 & 0 & 2 & 0.35 & $-0.860(0.231)$ & - & - & - \\
\hline$B \sim$ Forest cover & 73.8 & 0.1 & 3 & 0.33 & $-0.853(0.230)$ & $-0.326(0.250)$ & - & - \\
\hline$B \sim$ Forest cover + Edge density & 75.6 & 1.9 & 4 & 0.13 & $-0.865(0.236)$ & $-0.349(0.262)$ & $0.109(0.252)$ & - \\
\hline$B \sim$ Edge density & 75.6 & 1.9 & 3 & 0.13 & $-0.865(0.234)$ & $0.055(0.234)$ & - & - \\
\hline$B \sim$ Forest cover* Edge density & 77.2 & 3.5 & 5 & 0.06 & $-0.862(0.242)$ & $-0.411(0.284)$ & $0.198(0.293)$ & $0.164(0.259)$ \\
\hline \multicolumn{9}{|l|}{ Basileuterus flaveolos } \\
\hline$B \sim$ Null & 52 & 0 & 2 & 0.327 & $-1.080(0.265)$ & - & - & - \\
\hline$B \sim$ Edge density & 52 & 0 & 3 & 0.319 & $-1.130(0.275)$ & $-0.352(0.257)$ & - & - \\
\hline$B \sim$ Forest cover & 53.3 & 1.4 & 3 & 0.165 & $-1.171(0.296)$ & $0.213(0.271)$ & - & - \\
\hline$B \sim$ Forest cover + Edge density & 53.7 & 1.7 & 4 & 0.138 & $-1.187(0.297)$ & $0.150(0.268)$ & $0.324(0.259)$ & - \\
\hline$B \sim$ Forest cover* Edge density & 55.7 & 3.7 & 5 & 0.051 & $-1.193(0.301)$ & $0.172(0.320)$ & $-0.346(0.308)$ & $0.030(0.244)$ \\
\hline \multicolumn{9}{|l|}{ Poecilotriccus plumbeiceps } \\
\hline$B \sim$ Null & 39.8 & 0 & 2 & 0.493 & $-1.729(0.327)$ & - & - & - \\
\hline$B \sim$ Forest cover & 41.6 & 1.8 & 3 & 0.198 & $-1.707(0.329)$ & $0.128(0.306)$ & - & - \\
\hline$B \sim$ Edge density & 41.8 & 2 & 3 & 0.183 & $-1.730(0.327)$ & $0.049(0.375)$ & - & - \\
\hline$B \sim$ Forest cover + Edge density & 43.6 & 3.8 & 4 & 0.074 & $-1.707(0.329)$ & $0.133(0.310)$ & $0.058(0.364)$ & - \\
\hline$B \sim$ Forest cover* Edge density & 44.3 & 4.5 & 5 & 0.052 & $-1.818(0.362)$ & $-0.027(0.349)$ & $0.324(0.486)$ & $-0.355(0.322)$ \\
\hline \multicolumn{9}{|l|}{ Dysithamnus mentalis } \\
\hline$B \sim$ Null & 68 & 0 & 2 & 0.37 & $-1.553(0.234)$ & - & - & - \\
\hline$B \sim$ Edge & 68.5 & 0.5 & 3 & 0.29 & $-1.628(0.250)$ & $0.337(0.277)$ & - & - \\
\hline$B \sim$ Forest cover & 69.9 & 2 & 3 & 0.139 & $-1.553(0.234)$ & $-0.056(0.269)$ & - & - \\
\hline$B \sim$ Forest cover + Edge density & 70.4 & 2.4 & 4 & 0.113 & $-1.633(0.252)$ & $-0.096(0.281)$ & $0.354(0.287)$ & - \\
\hline$B \sim$ Forest cover* Edge density & 70.9 & 2.9 & 5 & 0.088 & $-1.689(0.264)$ & $-0.045(0.274)$ & $0.604(0.371)$ & $-0.373(0.306)$ \\
\hline
\end{tabular}


Table S3. Spillover richness and abundance into coffee matrices per sampling site. Forest cover corresponds to the percentage of forest cover around each sampling site within $800 \mathrm{~m}$ radius buffer (7.33 - 72.8\%, min-max), and edge density corresponds to the total area in hectares of forest-non-forest edge / area within the same $800 \mathrm{~m}$ buffer (30.8 - $120.7 \mathrm{~m} / \mathrm{ha}$, min-max). In-patch richness: total number of species inside forest patches; In-matrix richness: total number of species recorded inside coffee matrices; Spillover richness: as the overall number of forest-dependent species in the matrix in relation to the adjacent forest patch. In-patch abundance: total number of individuals inside forest patches; In-matrix abundance: total number of individuals recorded inside coffee matrices; Spillover abundance: the overall abundance of forest-dependent species in the matrix in relation to the adjacent forest patch.

\begin{tabular}{|c|c|c|c|c|c|c|c|c|}
\hline \multirow{3}{*}{ Sampling site } & \multirow[b]{3}{*}{ Edge density } & \multirow[b]{3}{*}{$\begin{array}{l}\text { Forest } \\
\text { cover }\end{array}$} & \multirow{2}{*}{\multicolumn{3}{|c|}{ 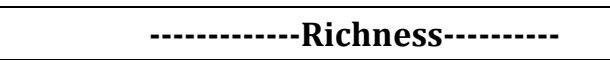 }} & \multirow{2}{*}{\multicolumn{3}{|c|}{---------Abundance------ }} \\
\hline & & & & & & & & \\
\hline & & & In-patch & In-matrix & $\begin{array}{l}\text { Spillover } \\
\text { Richness } \\
\end{array}$ & In-patch & In-matrix & $\begin{array}{l}\text { Spillover } \\
\text { Abundance }\end{array}$ \\
\hline $\mathrm{P} 02 \mathrm{a}$ & 81.18 & 57.51 & 24 & 2 & 0.08 & 55 & 6 & 0.11 \\
\hline $\mathrm{P} 02 \mathrm{~b}$ & 80.13 & 43.33 & 24 & 6 & 0.25 & 61 & 14 & 0.23 \\
\hline P02d & 77.79 & 51.59 & 32 & 3 & 0.09 & 46 & 12 & 0.26 \\
\hline P02c & 30.89 & 51.41 & 21 & 3 & 0.14 & 63 & 6 & 0.1 \\
\hline P09c & 88.19 & 19.02 & 16 & 0 & 0 & 54 & 0 & 0 \\
\hline P09a & 77.1 & 16.76 & 20 & 4 & 0.2 & 34 & 5 & 0.15 \\
\hline P09b & 73.23 & 14.03 & 15 & 2 & 0.13 & 36 & 4 & 0.11 \\
\hline P09d & 65.35 & 12.65 & 17 & 1 & 0.06 & 40 & 1 & 0.03 \\
\hline P10d & 93.36 & 44.39 & 24 & 2 & 0.08 & 67 & 5 & 0.07 \\
\hline P10a & 79.1 & 26.33 & 25 & 2 & 0.08 & 61 & 2 & 0.03 \\
\hline $\mathrm{P} 10 \mathrm{~b}$ & 64.46 & 21.69 & 25 & 3 & 0.12 & 77 & 6 & 0.08 \\
\hline P10c & 56.88 & 28.62 & 37 & 2 & 0.05 & 46 & 4 & 0.09 \\
\hline P11a & 120.79 & 51.86 & 27 & 3 & 0.11 & 62 & 7 & 0.11 \\
\hline $\mathrm{P} 11 \mathrm{~b}$ & 97.72 & 54.21 & 29 & 3 & 0.1 & 73 & 4 & 0.05 \\
\hline
\end{tabular}




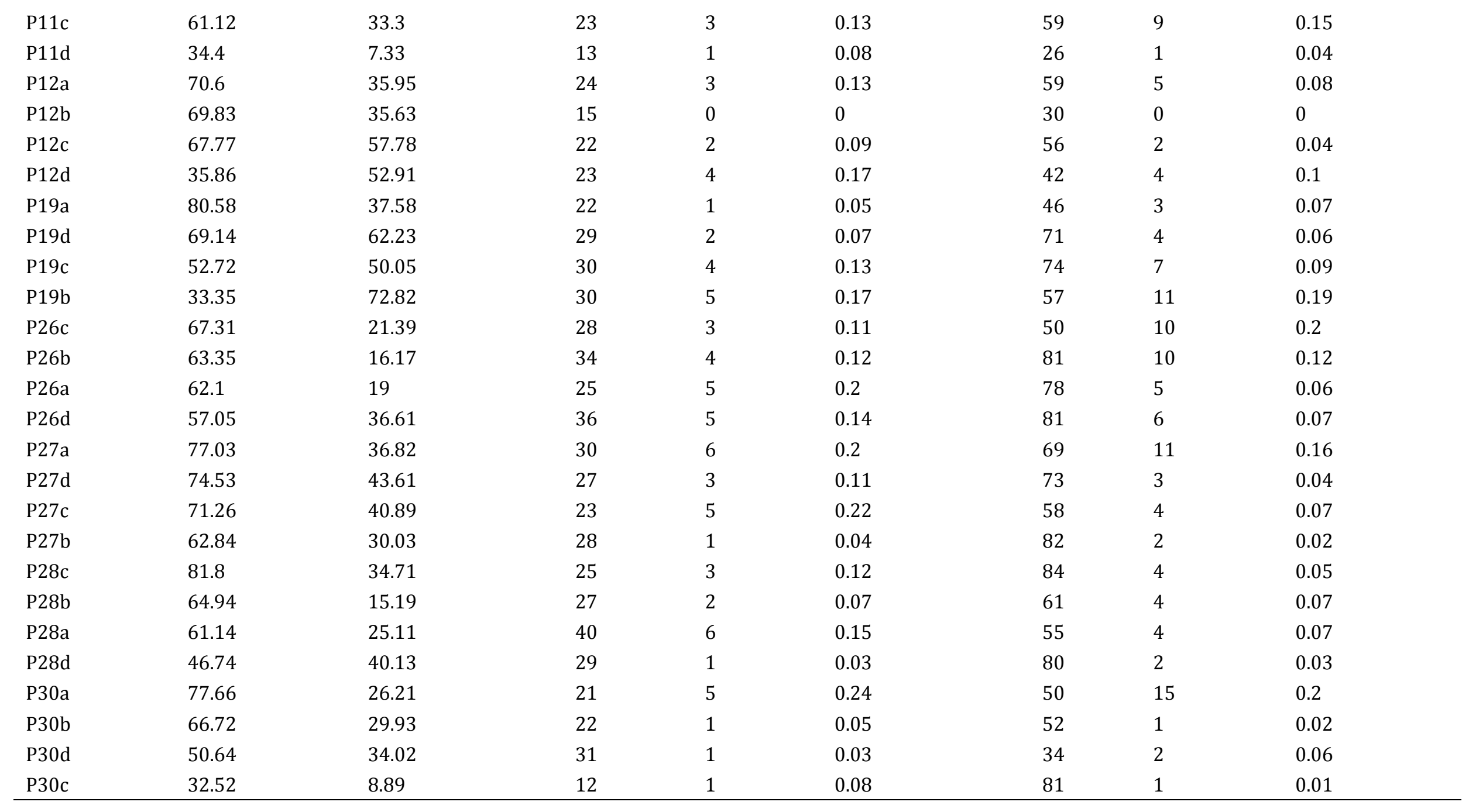


Table S4. Model selection for individual spillover abundance of Golden-crowned Warbler (Basileuterus culicivorus) and Variable Antshrike (Thamnophilus caerulescens) spilling over into coffee matrices. $B$ corresponds to individual spillover, AICc corresponds to the Akaike Information Criteria corrected to small samples, $\triangle \mathrm{AICc}$ is the difference between AICc from the best ranked model ( $\Delta \mathrm{AICc}$ ), $\mathrm{df}$ is the degrees of freedom, and AICc $\omega$ i is the evidence weight. Coefficients and standard errors (se) of each model are given. Var 1 corresponds to the first predictor variable in the model, Var 2 corresponds to the second predictor variable, and Interaction represents the interaction between the two. Forest cover corresponds to the percentage of forest cover around each sampling site within $800 \mathrm{~m}$ radius buffer (7.33 - 72.8\%, min-max), and edge density corresponds to the total area in hectares of forest-non-forest edge / area within the same $800 \mathrm{~m}$ buffer (30.8 - $120.7 \mathrm{~m} / \mathrm{ha}$, min-max). Distance from sampling point inside matrix to the nearest forest patch (50.3 - 159 m, min-max).

\begin{tabular}{|c|c|c|c|c|c|c|c|c|}
\hline \multirow[b]{3}{*}{ Model } & \multirow[b]{3}{*}{ AICc } & \multirow[b]{3}{*}{$\Delta$ AICc } & \multirow[b]{3}{*}{ df } & \multirow[b]{3}{*}{ AICc $\omega \mathbf{i}$} & \multirow{2}{*}{\multicolumn{4}{|c|}{ Coefficients }} \\
\hline & & & & & & & & \\
\hline & & & & & Intercept (se) & Var 1 (se) & Var 2 (se) & Interaction (se) \\
\hline \multicolumn{9}{|l|}{ Basileuterus culicivorus } \\
\hline$B$ - Distance & 99.2 & 0 & 3 & 0.265 & $-1.115(0.180)$ & $-0.410(0.208)$ & - & - \\
\hline$B$ - Distance*Forest cover & 100.5 & 1.3 & 5 & 0.136 & $-1.060(0.188)$ & $-0.277(0.238)$ & $0.185(0.190)$ & $0.403(0.284)$ \\
\hline$B$ - Distance + Forest cover & 100.9 & 1.6 & 4 & 0.117 & $-1.123(0.182)$ & $-0.387(0.214)$ & $0.106(0.177)$ & - \\
\hline$B$ - Distance* Edge density & 101.1 & 1.9 & 5 & 0.105 & $-1.049(0.185)$ & $-0.377(0.255)$ & $0.025(0.187)$ & $0.425(0.321)$ \\
\hline$B$ - Distance + Edge density & 101.2 & 2 & 4 & 0.098 & $-1.114(0.180)$ & $-0.405(0.213)$ & $0.018(0.181)$ & - \\
\hline$B$ - Null & 101.5 & 2.3 & 2 & 0.083 & $-1.06(0.173)$ & - & - & - \\
\hline$B-\mathrm{Fc}$ & 102.4 & 3.1 & 3 & 0.055 & $-1.077(0.175)$ & $0.183(0.169)$ & - & - \\
\hline$B$ - Edge & 103.1 & 3.9 & 3 & 0.037 & $-1.064(0.173)$ & $0.106(0.170)$ & - & - \\
\hline$B$ - Edge density*Forest cover & 103.9 & 4.6 & 5 & 0.026 & $-1.084(0.178)$ & $0.322(0.246)$ & $0.072(0.185)$ & $-0.267(0.190)$ \\
\hline$B$ - Edge density+ Forest cover & 104 & 4.8 & 4 & 0.023 & $-1.080(0.175)$ & $0.094(0.166)$ & $0.180(0.171)$ & - \\
\hline
\end{tabular}




\begin{tabular}{|c|c|c|c|c|c|c|c|c|}
\hline & \multirow{2}{*}{ AICc } & \multirow[b]{2}{*}{$\Delta \mathrm{AICc}$} & \multirow[b]{2}{*}{ df } & \multirow[b]{2}{*}{ AICc $\omega \mathbf{i}$} & \multicolumn{4}{|c|}{ Coefficients } \\
\hline & & & & & Intercept (se) & Var 1 (se) & Var 2 (se) & Interaction (se) \\
\hline \multicolumn{9}{|l|}{ Thamnophilus caerulescens } \\
\hline$B$ - Distance*Forest cover & 66.1 & 0 & 5 & 0.393 & $-1.072(0.245)$ & $0.724(0.351)$ & $0.516(0.233)$ & $0.734(0.392)$ \\
\hline$B-F c$ & 68.2 & 2 & 3 & 0.141 & $-1.131(0.232)$ & $0.362(0.207)$ & - & - \\
\hline$B$ - Distance+ Forest cover & 68.7 & 2.5 & 4 & 0.11 & $-1.183(0.242)$ & $0.356(0.291)$ & $0.455(0.225)$ & - \\
\hline$B$ - Null & 69.3 & 3.2 & 2 & 0.08 & $-1.049(0.219)$ & - & - & - \\
\hline$B$ - Edge density+ Forest cover & 69.7 & 3.6 & 4 & 0.065 & $-1.149(0.236)$ & $0.127(0.188)$ & $0.360(0.210)$ & - \\
\hline$B$ - Edge density*Forest cover & 69.8 & 3.6 & 5 & 0.064 & $-1.182(0.248)$ & $0.462(0.336)$ & $0.260(0.221)$ & $-0.313(0.239)$ \\
\hline$B$ - Distance*Edge distance & 70.2 & 4.1 & 5 & 0.051 & $-1.005(0.230)$ & $0.390(0.300)$ & $0.181(0.214)$ & $0.522(0.331)$ \\
\hline$B$ - Edge density & 70.7 & 4.6 & 3 & 0.04 & $-1.070(0.222)$ & $0.152(0.194)$ & - & - \\
\hline$B$ - Distance & 71 & 4.8 & 3 & 0.035 & $-1.060(0.221)$ & $0.147(0.251)$ & - & - \\
\hline$B$ - Distance + Edge density & 72 & 5.9 & 4 & 0.021 & $-1.094(0.227)$ & $0.229(0.268)$ & $0.202(0.203)$ & - \\
\hline
\end{tabular}



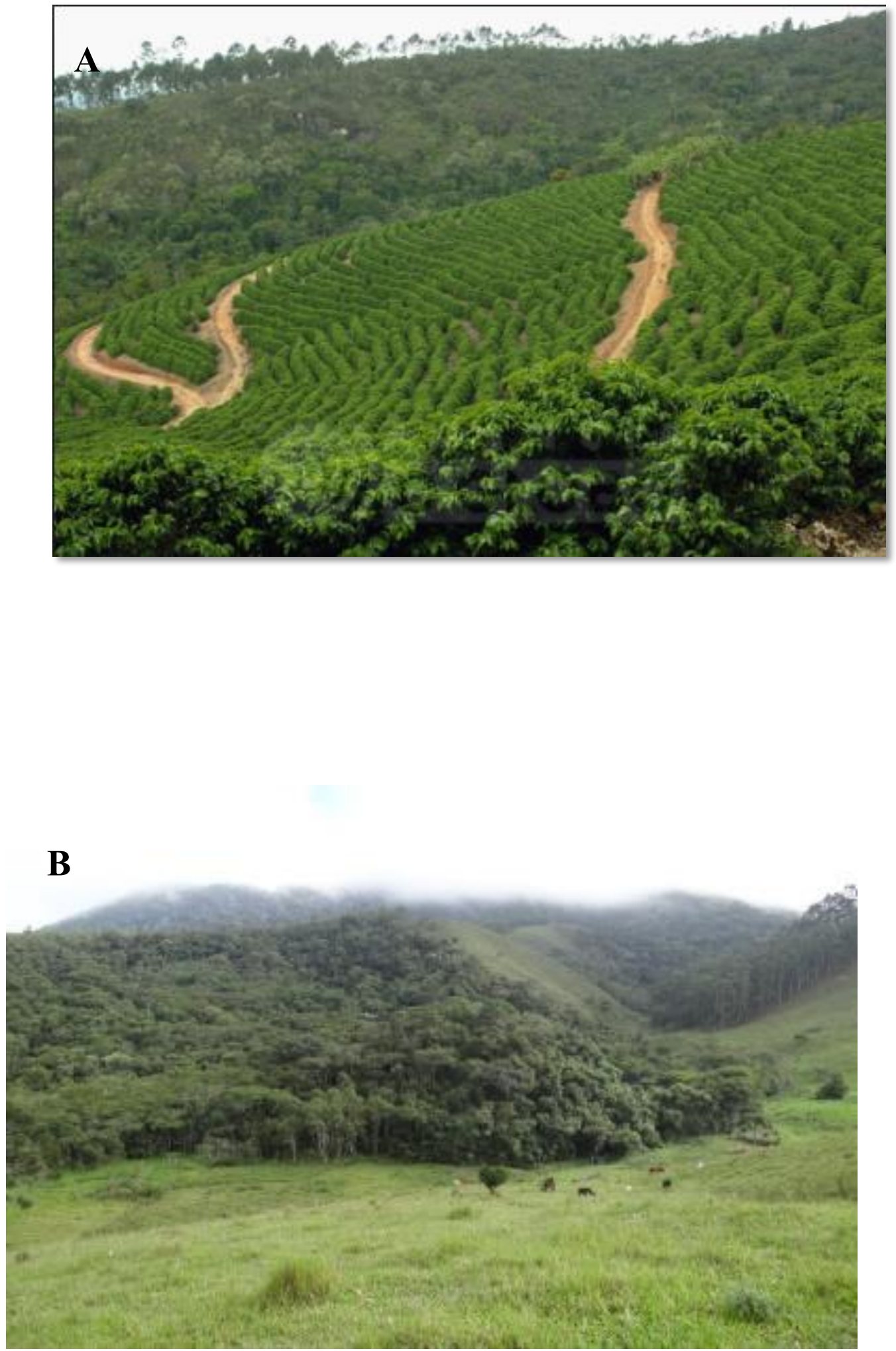

Figure S1. Illustration of matrix composition in studied areas. (A) coffee matrix; (B) pasture matrix. 

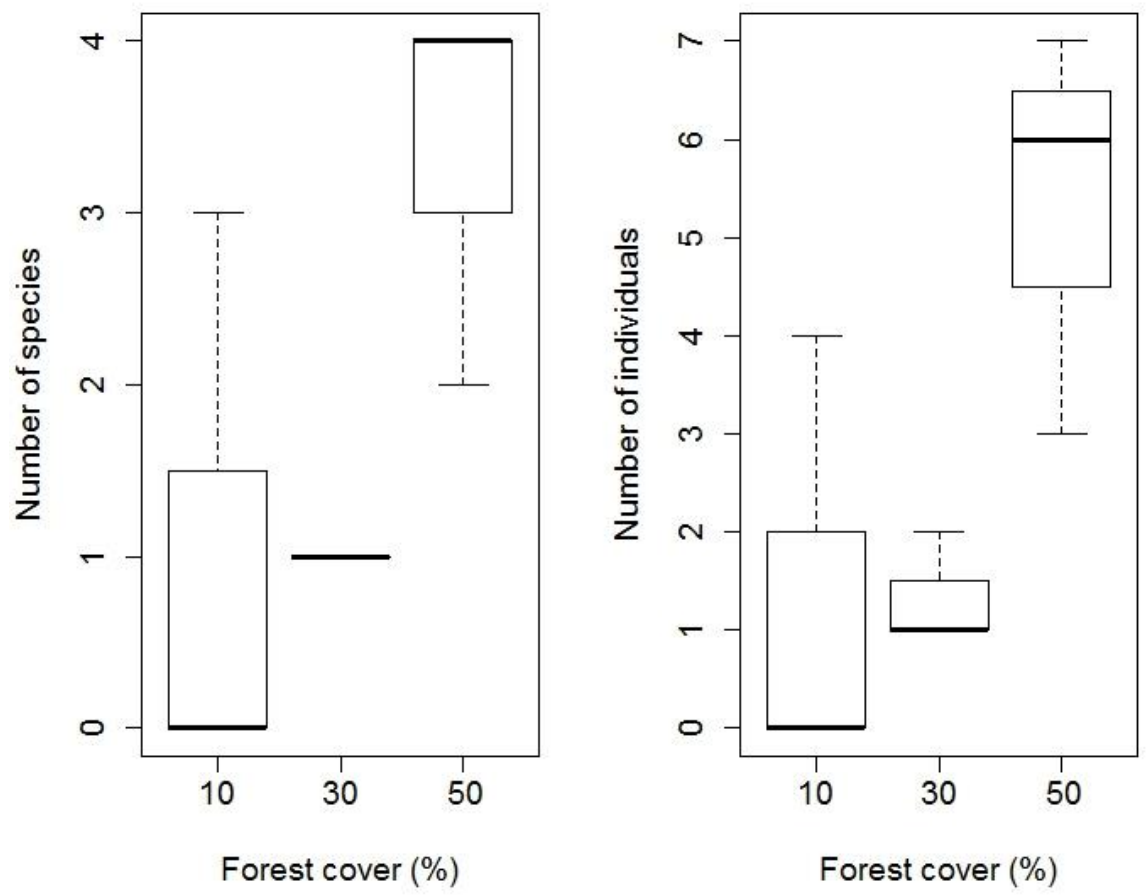

Figure S2. Median and respective $25 \%$ and $75 \%$ quartiles of both number of species and number of individuals caught spilling over at forest edges embedded in three landscapes with low (10\%), intermediate (30\%) and high (50\%) forest cover. 


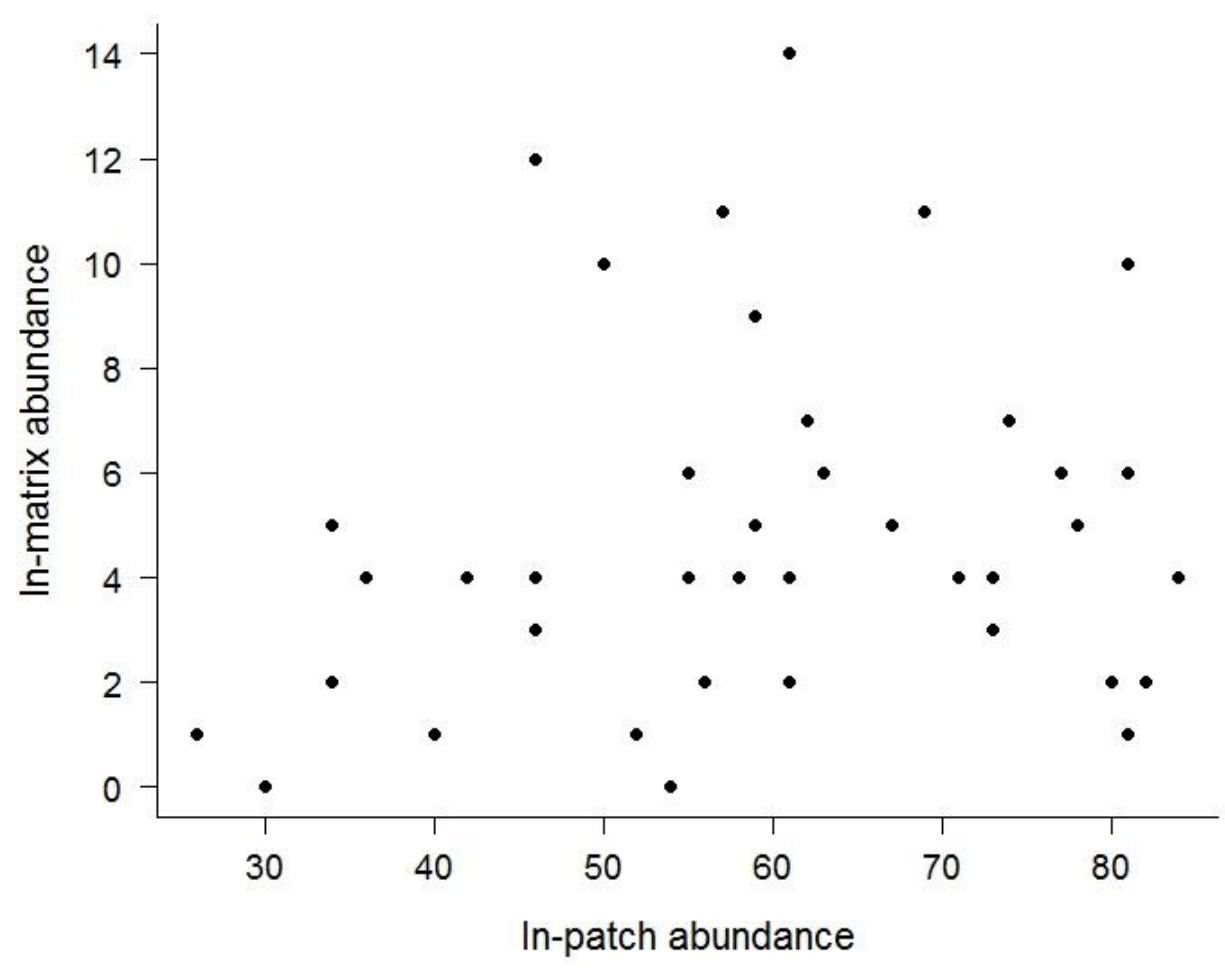

Figure S3. Pearson-correlation between in-patch bird abundance and spillover bird abundance (total of individuals) in coffee matrices ( $r=0.18, \mathrm{p}=0.487$ ). 


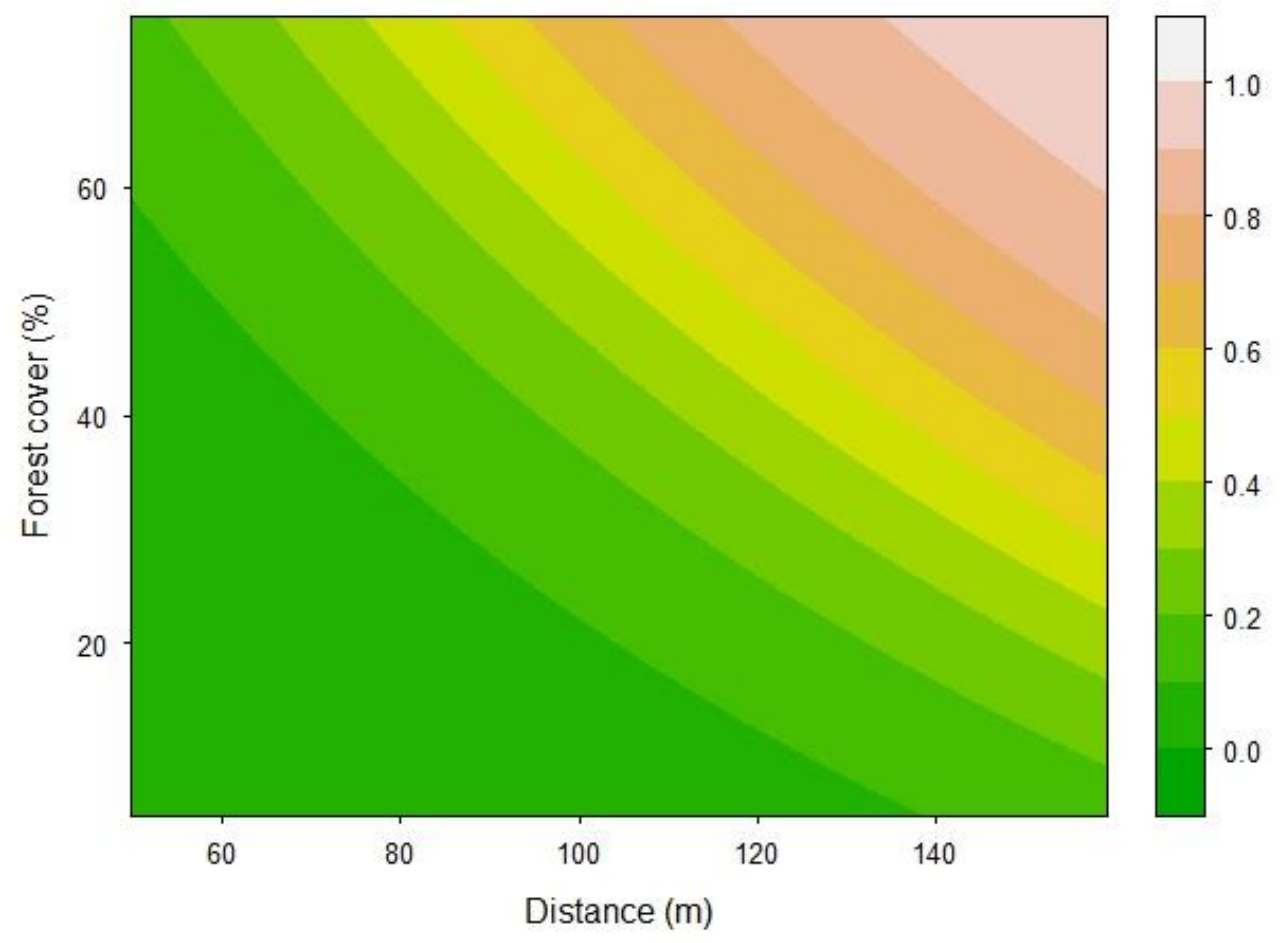

Figure S4. Predicted individual spillover abundance of the Variable Antshrike Thamnophilus caerulescens in coffee matrices using the top-ranked AICc model, including the interaction between forest cover and distance from nearest habitat patch. 


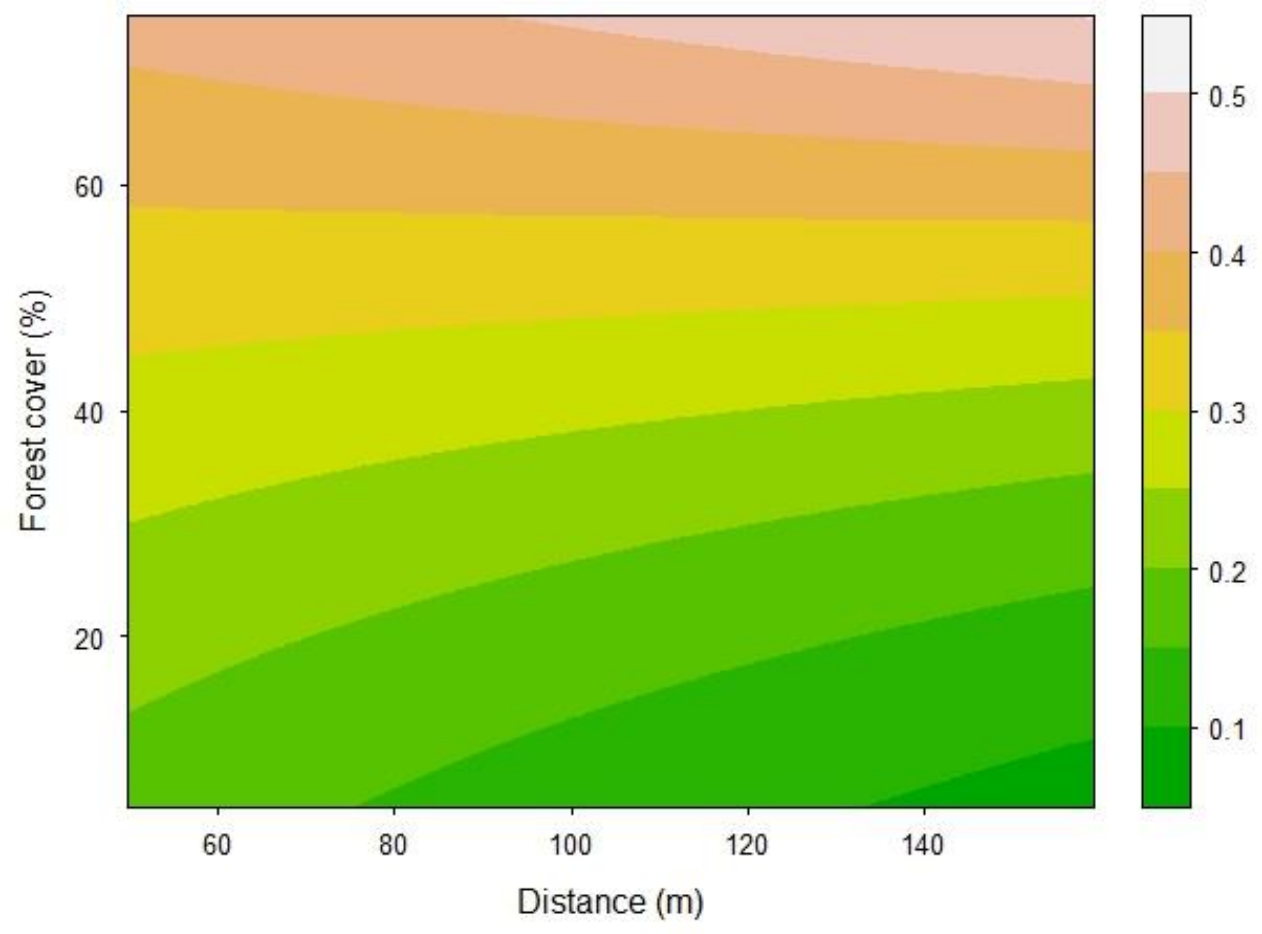

Figure S5. Predicted individual spillover abundance of the Golden-crowned Warbler Basileuterus culicivorus in coffee matrices using the second top-ranked AICc model, including the interaction between forest cover and distance from nearest habitat patch. 


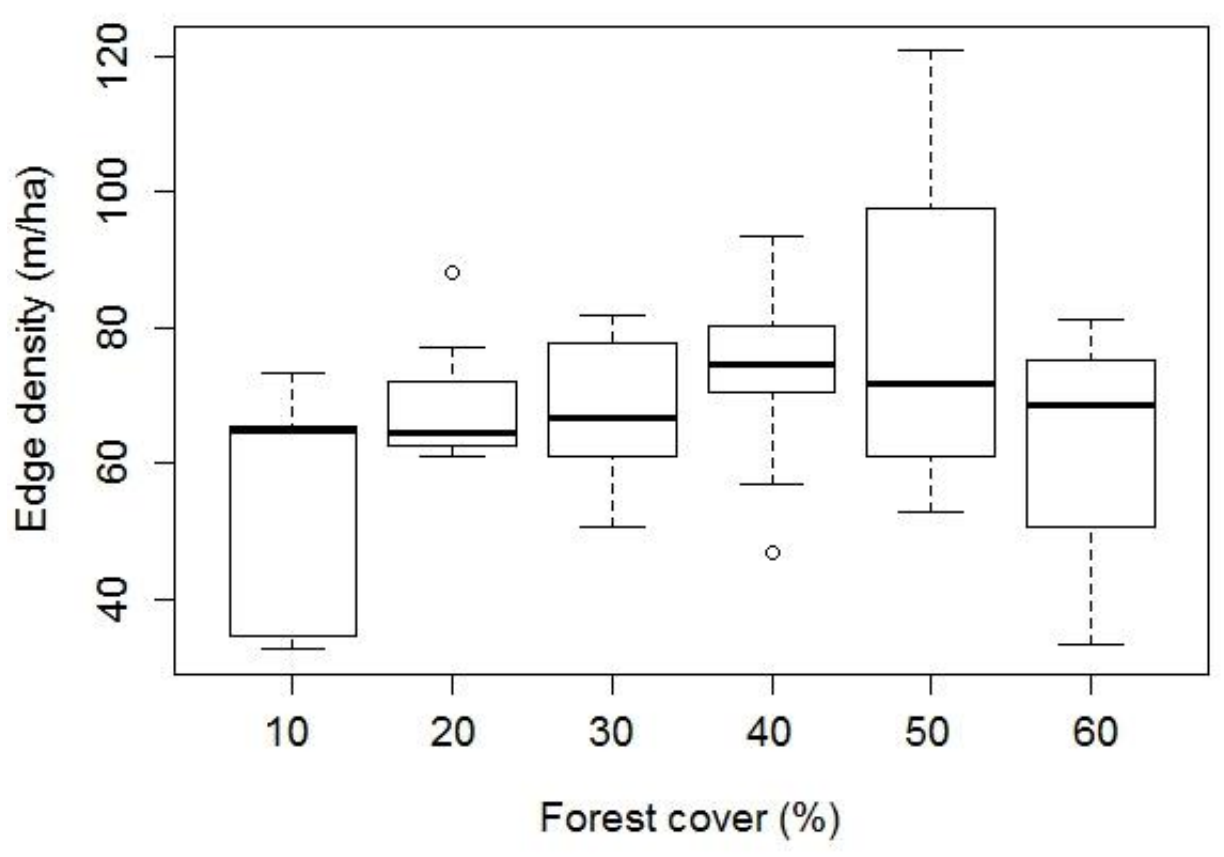

Figure S6. Edge density distributed according forest cover gradient in coffee matrices. 


\section{General Discussion}

Agricultural intensification, along with other environmental changes such as climate change, pollution, and species invasion, has currently degraded biodiversity to such an extent that many ecosystem services contributing to human well-being are becoming increasingly eroded (Hooper et al. 2005, MEA 2005, Bommarco et al. 2013). To minimize this degradation process, a current challenge is to plan multifunctional landscapes that, in addition to support crop production, are able to maintain biological diversity and its ecological functions (Foley et al. 2005). Despite the growing knowledge base on ecosystem services provision (Albert et al. 2014), current implementing of ecosystem services science in practical planning and decision-making at landscape scale is in its infancy (Daily et al. 2009).

In chapter one, we demonstrate that a large number of bird species may provide pest control services in agricultural systems worldwide, and that a substantial proportion of avian predators are native habitat-dependent species in tropical systems, suggesting a link between native habitat management and the maintenance of pest control services. We have found 226 bird species that provide pest regulation worldwide, and a substantial proportion of those are native habitat-dependent species in tropical systems. Moreover, more heterogeneous landscapes, increased habitat amount, and decreased isolation among patches are positively associated with increased avian-mediated pest control rates. We highlight that highly-connected crop-noncrop mosaics may be best for long-term conservation of pest control services (Tscharntke et al. 2007). Based on our findings, we propose a conceptual model that highlights the role of landscape-level processes affecting the main mechanisms related to avian-mediated pest control, including (i) the persistence of avian predators in agricultural habitats, (ii) the dispersal ability of avian predators into and through crop fields, and (iii) trophic interactions between assemblages of natural enemies and pests.

In the second chapter we move forward investigating the processes modulating bird persistence in agricultural landscapes and demonstrate that matrix composition strongly affects the dynamics of biodiversity thresholds not only for the taxonomic diversity, but also for the functional and phylogenetic 
diversity of bird assemblages. Even though we demonstrate that more permeable matrices might postpone species loss in fragmented landscapes, when deforestation reaches $20 \%$ remaining habitat, not only species richness, but also important aspects of functional and phylogenetic structure of bird assemblages collapse. These changes may have important implications in terms of ecosystem functioning and ecosystem resilience, since a large proportion of the original functions performed by bird species, such as insectivory and frugivory, are lost below this threshold, and some specific branches of the phylogeny are lost as well. Since the historical context plays an important role in assembling phylogenetic structure of studied bird assemblages, we highlight the importance of maintaining preserved tracks of native forest as source of individuals that can colonize new patches in order to maintain more heterogeneous communities. In addition, increasing matrix permeability is key in enhancing landscape connectivity, and allowing species movement and persistence in these highly fragmented landscapes. For practical purposes, taxonomic diversity seems to be the best predictor index of biodiversity loss in fragmented landscapes, since it is the first index to be affected - especially in high-contrasting matrices - and therefore detecting a minimal habitat cover threshold for taxonomic diversity can prevent subsequent functional and phylogenetic loss.

Finally, in chapter three, we demonstrated the importance of matrix permeability and landscape heterogeneity in regulating species movement among patches and facilitating avian cross-habitat spillover of forest-dependent species into agricultural matrices. We have found that (1) matrix composition plays a key role in facilitating bird movement into agricultural matrices, where very contrasting matrices act as a barrier to species movement and less contrasting matrices act as a semi-permeable filter, facilitating bird movement into managed areas; (2) that edge density has important effects on spillover in more permeable matrices, especially in lower amounts of habitat, which might be due both complementation and supplementation processes at landscape scale and an increased landscape connectivity, and (3) habitat amount is important in promoting spillover when matrix and native habitats are high-contrast, because although most species avoid high-contrast matrices, some species travel short distances across them to reach other habitat patches. Increasing the structural 
similarity between matrix and native patches will promote species movement, ensuring species persistence and avian-mediated ecosystem services. Matrix management matters, as matrix land cover dominates the world's terrestrial ecosystems (Vitousek et al. 1997, MEA 2005). Although large-scale conversion to high-quality matrix might not be a realistic option, even small punctual changes in matrix making it more heterogeneous or permeable may be a feasible and effective conservation strategy (Ruffell et al. 2016).

Our results suggest that landscape configuration and matrix composition should be considered when planning agricultural landscapes in order to ensure long-term persistence and ecosystem services provision in highly fragmented landscapes. Increasing matrix permeability through land uses that provide substantial resources, facilitate dispersal, and create lower-edge contrast (Kupfer et al. 2006) might reduce the impacts of habitat loss on bird communities and also guarantee avian-mediated ecosystem services provisioning. Increasing spatial heterogeneity in agricultural landscapes, for example by adding stepping stones, strips, or even hedgerows, may be beneficial for many forest-dependent species that can use these elements to move through matrices (Uezu et al. 2008). Matrix permeability might also be increased through enhancement of crop diversity and decreased land management intensity (Perfecto and Vandermeer 2010). Continued efforts are necessary to more fully understand how and why landscape configuration and composition influence forest-dependent mobile organisms and biodiversity-mediated-ecosystem services, especially in fragmented tropical landscapes.

This study is part of Project Interface ${ }^{1}$, a research project that aims to contribute to the understanding and planning of multifunctional landscapes capable of sustaining both biodiversity and the ecosystem services essential for human well-being.

Conserving biodiversity in agricultural landscapes no longer implies a focus solely on species richness, but also on ecological functions performed by species and on evolutionary history supported by lineages (Diniz-Filho et al. 2013). An integrative approach would seek the mechanistic underpinning of ecosystem

\footnotetext{
${ }^{1}$ http://ecologia.ib.usp.br/projetointerface/en/
} 
responses to species loss by focusing on the relationships among species, traits, phylogeny, biotic and abiotic factors affecting these relationships, and how they ultimately affect ecosystem functioning (Naeem et al. 2012, Monnet et al. 2014). The general pattern that has arisen in our study it that increasing both landscape heterogeneity and matrix permeability, in addition to native habitat conservation, is a key management action to implement in order to guarantee bird persistence in anthropogenic landscapes and the provisioning of ecosystem services.

\section{Literature cited}

Albert, C., J. Aronson, C. Furst, and P. Opdam. 2014. Integrating ecosystem services in landscape planning: requirements, approaches, and impacts. Landscape Ecology 29:1277-1285.

Bommarco, R., D. Kleijn, and S. G. Potts. 2013. Ecological intensification: harnessing ecosystem services for food security. Trends in Ecology \& Evolution 28:230-238.

Daily, G. C., S. Polasky, J. Goldstein, P. M. Kareiva, H. A. Mooney, L. Pejchar, T. H. Ricketts, J. Salzman, and R. Shallenberger. 2009. Ecosystem services in decision making: time to deliver. Frontiers in Ecology and the Environment 7:21-28.

Diniz-Filho, J. A. F., R. D. Loyola, P. Raia, A. O. Mooers, and L. M. Bini. 2013. Darwinian shortfalls in biodiversity conservation. Trends in Ecology \& Evolution 28:689-695.

Foley, J. A., R. DeFries, G. P. Asner, C. Barford, G. Bonan, S. R. Carpenter, F. S. Chapin, M. T. Coe, G. C. Daily, H. K. Gibbs, J. H. Helkowski, T. Holloway, E. A. Howard, C. J. Kucharik, C. Monfreda, J. A. Patz, I. C. Prentice, N. Ramankutty, and P. K. Snyder. 2005. Global consequences of land use. Science 309:570-574.

Hooper, D. U., F. S. Chapin, J. J. Ewel, A. Hector, P. Inchausti, S. Lavorel, J. H. Lawton, D. M. Lodge, M. Loreau, S. Naeem, B. Schmid, H. Setala, A. J. Symstad, J. Vandermeer, and D. A. Wardle. 2005. Effects of biodiversity on ecosystem functioning: A consensus of current knowledge. Ecological Monographs 75:3-35. 
Kupfer, J. A., G. P. Malanson, and S. B. Franklin. 2006. Not seeing the ocean for the islands: the mediating influence of matrix-based processes on forest fragmentation effects. Global Ecology and Biogeography 15:8-20.

MEA. 2005. Millennium Ecosystem Assessment Synthesis, United Nations.

Monnet, A.-C., F. Jiguet, C. N. Meynard, D. Mouillot, N. Mouquet, W. Thuiller, and V. Devictor. 2014. Asynchrony of taxonomic, functional and phylogenetic diversity in birds. Global Ecology and Biogeography 23:780-788.

Naeem, S., J. E. Duffy, and E. Zavaleta. 2012. The Functions of Biological Diversity in an Age of Extinction. Science 336:1401-1406.

Perfecto, I. and J. Vandermeer. 2010. The agroecological matrix as alternative to the land-sparing/agriculture intensification model. Proceedings of the National Academy of Sciences of the United States of America 107:57865791.

Ruffell, J., C. Mick, and R. K. Didham. 2016. The matrix matters, but how should we manage it? Estimating the amount of high-quality matrix required to maintain biodiversity in fragmented landscapes. Ecography 39:001-008.

Tscharntke, T., R. Bommarco, Y. Clough, T. O. Crist, D. Kleijn, T. A. Rand, J. M. Tylianakis, S. van Nouhuys, and S. Vidal. 2007. Conservation biological control and enemy diversity on a landscape scale. Biological Control 43:294-309.

Uezu, A., D. D. Beyer, and J. P. Metzger. 2008. Can agroforest woodlots work as stepping stones for birds in the Atlantic Forest region? . Biodiversity and Conservation 17:1907-1922.

Vitousek, P. M., H. A. Mooney, J. Lubchenco, and J. M. Melilli. 1997. Human domination of Earth's ecosystems. Science 277:494-499. 


\section{Abstract}

The influence of habitat loss on biodiversity is related to a set of non-linear processes, which strongly affect isolation and connectivity and determine both extinction and colonization rates. Landscape changes due anthropogenic disturbances are driving not only species loss per se, but also loss of functions performed by those species, which could have important impacts on the provision of ecosystem services and ecosystem function. The objective of this dissertation is to move beyond our current understanding about landscape processes underpinning bird persistence and avian-mediated pest control in fragmented landscapes. In chapter 1 , we systematically review the empirical evidence of landscape structure effects on avian-mediated pest control in agricultural systems worldwide in order to point out the main landscape processes underpinning ecosystem service provision and gaps in knowledge where research efforts should be focused. We have found 226 bird species that provide pest regulation worldwide, and a substantial proportion of those are native habitat-dependent species in tropical systems. Moreover, more heterogeneous landscapes, increased habitat amount, and decreased isolation among patches are positively associated with increased avian-mediated pest control rates. Then, using bird data collected in fragmented landscapes in the Brazilian Atlantic forest, in chapter 2 we test for community-level extinction thresholds across a range of biodiversity indices (taxonomic, functional, and phylogenetic diversity) in order to evaluate how much habitat is need to maintain sustainable ecosystem functioning and ecosystem resilience, and how matrix composition might affect these thresholds. In general, we have found that more permeable matrices are able to postpone species loss in fragmented landscapes. However, since habitat loss reaches $20 \%$ of habitat remaining, all aspects of biodiversity are compromised. Finally, in chapter 3 we investigate the cross-habitat spillover process - one of the main processes regulating avian-mediated pest control in tropical regions. Matrix composition is a key factor in facilitating species movement into matrices, as $24 \%$ of the species pool can spill over into coffee plantations, while spillover into pasture is nearly non-existent. Moreover, the interaction between forest cover and edge density is 
an important predictor of spillover when habitat amount is low. Our results suggest that landscape configuration and matrix composition should be considered when planning agricultural landscapes in order to ensure long-term persistence of biodiversity and ecosystem services provision. 


\section{Resumo}

O efeito da perda de habitat sobre a biodiversidade está ligado a um conjunto de processos não-lineares que fortemente afetam a conectividade e o isolamento da paisagem, e determinam taxas de extinção e colonização. Mudanças na estrutura da paisagem desencadeadas por distúrbios antropogênicos levam não somente à perda de espécies per se, mas também a perda de funções que estas espécies desempenham no ecossistema, com importantes implicações em termos de funcionalidade e provisão de serviços ecossistêmicos. O objetivo geral desta tese é elucidar os processos, que ocorrem no nível da paisagem, que modulam a persistência de aves e, consequentemente, as funções destas aves na provisão do controle de pragas em paisagens fragmentadas. No primeiro capítulo da tese, nós revisamos sistematicamente as evidências empíricas dos efeitos da estrutura da paisagem sobre o controle de pragas provido por aves em sistemas agrícolas ao redor do mundo, identificando os processos, no nível da paisagem, subjacentes a este controle e as lacunas de conhecimento onde futuros esforços devem ser concentrados. Identificamos 226 espécies de aves provendo controle de pragas em sistemas agrícolas, sendo que uma porção substancial destas espécies em sistemas tropicais são dependentes de habitats nativos. Em geral, paisagens mais heterogêneas, com elevada cobertura de habitat nativo e menor isolamento entre fragmentos estão positivamente relacionados com elevadas taxas de controle de pragas provido por aves. Por conseguinte, no segundo capítulo, usamos dados de aves em paisagens fragmentadas emersas em diferentes contextos de matriz agrícola na Mata Atlântica brasileira, para testar limiares de extinção ao nível de comunidade. Foram usadas diferentes métricas de diversidade biológica (taxonômica, funcional e filogenética), com o intuito de avaliar o quanto de habitat é necessário para garantir o funcionamento e resiliência do ecossistema. Nós encontramos que matrizes mais permeáveis são capazes de postergar a perda de espécies em paisagens fragmentadas, no entanto, quando a perda de habitat alcança o limiar crítico de $20 \%$, todos os aspectos da biodiversidade estão comprometidos, independentemente do tipo de matriz. Por fim, no capítulo 3, nós investigamos o processo de 'transbordamento' (i.e. spillover), um dos principais processos reguladores da provisão do serviço de controle de pragas pela biota dependente de habitats nativos. Nós demonstramos que a composição da matriz é um fator determinante facilitando o movimento de espécies para as matrizes agrícolas, 
sendo que $24 \%$ do pool de espécies consegue utilizar matrizes de cafezal, enquanto este movimento é quase inexistente em matrizes de pastagem. Ademais, em paisagens com pouca cobertura florestal, a interação entre cobertura florestal e densidade de borda é um importante preditivo do spillover. Nossos resultados sugerem que a configuração da paisagem e a composição da matriz devem ser consideradas no planejamento de paisagens agrícolas para garantir a persistência em longo prazo da biodiversidade e a provisão de serviços ecossistêmicos. 